\title{
FABRICATING FIDELITY: NATION-BUILDING, INTERNATIONAL LAW, AND THE GREEK-TURKISH POPULATION EXCHANGE
}

by

\begin{abstract}
Umut Özsu
A thesis submitted in conformity with the requirements

for the degree of Doctor of Juridical Sciences

Faculty of Law

University of Toronto
\end{abstract}

C Copyright by Umut Özsu (2011) 
Abstract

\title{
FABRICATING FIDELITY: NATION-BUILDING, INTERNATIONAL LAW, AND THE GREEK-TURKISH POPULATION EXCHANGE
}

\author{
Umut Özsu \\ Doctor of Juridical Sciences (S.J.D.) \\ Faculty of Law \\ University of Toronto
}

2011

This dissertation concerns a crucial episode in the international legal history of nation-building: the Greek-Turkish population exchange. Supported by Athens and Ankara, and implemented largely by the League of Nations, the population exchange showcased the new pragmatism of the post-1919 order, an increased willingness to adapt legal doctrine to local conditions. It also exemplified a new mode of non-military nation-building, one initially designed for sovereign but politico-economically weak states on the semi-periphery of the international legal order. The chief aim here, I argue, was not to organize plebiscites, channel self-determination claims, or install protective mechanisms for vulnerable minorities - all familiar features of the Allied Powers' management of imperial disintegration in central and eastern Europe after the First World War. Nor was the objective to restructure a given economy and society from top to bottom, generating an entirely new legal order in the process; this had often been the case with colonialism in Asia and Africa, and would characterize much of the mandates system 
throughout the interwar years. Instead, the goal was to deploy a unique mechanism - not entirely in conformity with European practice, but also distinct from non-European governance regimes - to reshape the demographic composition of Greece and Turkey.

I substantiate this argument by marshalling a range of material from international law, legal history, and historical sociology. I first examine minority protection's development into an instrument of intra-European nation-building during the long nineteenth century, showing how population exchange emerged in the Near East in the 1910s as a radical alternative to minority protection. I then provide a close reading of the travaux préparatoires of the 1922-3 Conference of Lausanne, at which a peace settlement formalizing the exchange was concluded. Finally, I analyze the Permanent Court of International Justice's 1925 opinion in Exchange of Greek and Turkish Populations, examining it from the standpoint of wide-ranging disputes concerning the place of religion and ethnicity in the exchange process. My aim throughout is to show that the Greek-Turkish exchange laid the groundwork for a mechanism of legal nation-building which would later come to be deployed in a variety of different contexts but whose precise status under international law would remain contested. 
for Allison Glaser, who endured it with wisdom and elegance, Nuran and Tamer Özsu, who supported it from the beginning, and Emma, who always remained by my side 


\section{ACKNOWLEDGMENTS}

My grandfather, Nureddin Özsu, was a frustrated student of law. Born to a family of modest means, he left his provincial hometown to study in Istanbul in the 1930s. He was forced to abandon his studies at the University of Istanbul Faculty of Law midway through his degree, however, when he was drafted into the army during the Second World War (in preparation for an invasion which, happily, never materialized). He settled for a civil service career in the small, dusty town of Tavşanll, eventually moving from there to Ankara.

An ardent secularist, convinced of the necessity of modernization, my grandfather was also a life-long student of tasavuf, the canon of Sufi teaching. In principle, he was as staunch an advocate of women's rights as any of his contemporaries; in practice, he insisted on maintaining a rigid division of labour within the home. Committed though he was to nationalism, he was embarrassed by what had been done to minority peoples in its name. He held down a number of office jobs, but always nursed literary ambitions.

I would have liked to have been able to show my grandfather - whom neither I nor anyone else knew intimately - that the law to which he had wanted to devote himself as a young man is at least as patchy and pock-marked, as shot through with contradiction, as he was. Perhaps it is better that I never got the chance.

My supervisors, Jutta Brunnée and Karen Knop, deserve my sincere and heartfelt thanks for nearly four years of guidance and encouragement. Jutta shepherded the dissertation through treacherous theoretical territory, and helped sharpen its arguments greatly. Karen was a touchstone for interwar international law, and helped frame and finesse the project enormously. Draft after draft, meeting after meeting, their astute and detailed comments proved invaluable.

Nehal Bhuta offered a number of suggestions at the project's outset which played a critical role in its design and development. I thank him for these suggestions, as well as for his helpful comments on the final dissertation. 
I drew upon Nergis Canefe's knowledge of historical sociology when initially conceptualizing the project. I also thank her for facilitating some of my research in Turkey.

I was deeply honoured to have Anne Orford as my external examiner. I thank her for an exceptionally careful reading of the dissertation, and for a number of penetrating suggestions and observations that I will be pondering closely over the months to come.

I have benefited from conversation and correspondence with a variety of scholars, legal and non-legal, during the course of my graduate studies. For counsel, criticism, engagement with draft material, or simply for forwarding their own published or unpublished work, my thanks go to Nathaniel Berman, Tanıl Bora, Bill Bowring, B. S. Chimni, Matthew Craven, Fuat Dündar, David Dyzenhaus, Anver Emon, Huri İslamoğlu, David Kennedy, Hans-Lukas Kieser, Martti Koskenniemi, Patrick Macklem, Erez Manela, Susan Marks, Mark Mazower, Lauri Mälksoo, Frédéric Mégret, China Miéville, Akbar Rasulov, Kerry Rittich, Thomas Skouteris, Turgut Tarhanl, Mark Toufayan, Keith David Watenpaugh, and Peer Zumbansen. I also thank the large number of graduate students, in Toronto and elsewhere, with whom I exchanged ideas, compared notes, and refined allegiances.

Staff at the University of Toronto's Robarts and Bora Laskin libraries, Osgoode Hall Law School's library, the National Library of Turkey, and Columbia University's Rare Book and Manuscript Library assisted diligently. Ahmet Yüksel, antiquarian bookseller extraordinaire, was particularly helpful in locating less accessible material in Ankara.

Finally, my thanks go to the University of Toronto Faculty of Law, the University of Toronto School of Graduate Studies, and the Social Sciences and Humanities Research Council of Canada for their generosity and institutional support. 


\section{CONTENTS}

TABLE OF TREATIES AND OTHER INSTRUMENTS

TABLE OF CASES

LIST OF ABBREVIATIONS

NOTE ON TRANSLATION AND TRANSLITERATION

INTRODUCTION 1

Organization of the Dissertation 6

The International Legal Field of the Exchange 13

Distinguishing the Problematic 18

CHAPTER I. Governing the Ungovernable: Turkey and the International 26 Law of Minority Protection, 1815-1923

Minority Protection as Collective Action - The Long Nineteenth Century 27

Managing Minorities in a New World Order

Before and After the Exchange $\quad 57$

CHAPTER II. En Route to the Exchange: Demographic Engineering in the 67 Near East, 1913-9

Early Experiments in Demographic Engineering 69

A Refuge for the Displaced $\quad 80$

Toward a Definitive Arrangement $\quad 92$ 
CHAPTER III. “A Subject Which Excites the Deepest Interest throughout the Civilised World": Lausanne and the Craft of Diplomatic Nation-Building

Bargaining Ethno-Nationalism

An Enterprise neither European nor Non-European

Two Tensions Enshrined

CHAPTER IV. Litigating the Exchange before the World Court:

Humanitarianism and the Mobilization of an International Legal

Community

"To Bring upon Turkey the Pressure of Moral Force"

"National Sovereignty is Not Affected by the Convention in Question"

Intervention and Interpretation

CONCLUSION

BIBLIOGRAPHY

173 


\section{TABLE OF TREATIES AND OTHER INSTRUMENTS}

Traité de paix, d'amitié et de commerce [février 1535], reproduced in I. de Testa, Recueil des traités de la Porte ottomane avec les puissances étrangères depuis le premier traité conclu, en 1536, entre Suléyman I et François I, jusqu'à nos jours, Vol. I (Paris: Amyot, 1864) 15.

Treaty of Peace and Frontiers: The Ottoman Empire and Persia, 17 May 1639, 105 BFSP 763.

Treaty of Perpetual Peace and Amity between Russia and Turkey, signed at Kuçuk Kainardji, 10(21) July 1774, 45 CTS 349.

Act of the Congress of Vienna, signed between Austria, France, Great Britain, Portugal, Prussia, Russia and Sweden, 9 June 1815, 64 CTS 453.

Treaty between France, Great Britain and Russia for the Pacification of Greece, signed at London, 6 July 1827, 77 CTS 307.

Arrangement between France, Great Britain and Russia, and Turkey, for the Definitive Settlement of the Continental Boundaries of Greece, signed at Constantinople, 21 July 1832, 82 CTS 477.

Convention of Commerce and Navigation between Great Britain and Turkey, signed at BaltaLiman, 16 August 1838, 88 CTS 77.

General Treaty for the Re-Establishment of Peace between Austria, France, Great Britain, Prussia, Sardinia and Turkey, and Russia, signed at Paris, 30 March 1856, 114 CTS 409.

Treaty between Austria-Hungary, France, Germany, Great Britain, Italy, Russia and Turkey for the Settlement of Affairs in the East, signed at Berlin, 13 July 1878, 153 CTS 171.

Treaty of Peace between Bulgaria and Turkey - Constantinople, September 16 (29), 1913, 107 BFSP 706.

Ottoman Circular Announcing the Abrogation of the Capitulations, 9 September 1914, reproduced in J. C. Hurewitz, ed., Diplomacy in the Near and Middle East: A Documentary Record: 1914-1956, Vol. II (New York: Octagon, 1972) 2.

Exchange of Letters between France and Great Britain respecting the Recognition and Protection of an Arab State in Syria, 9 May 1916, 221 CTS 323.

Armistice Convention between Great Britain and the Allied Powers, and Turkey, signed at Mudros, October 30, 1918, 224 CTS 169. 
Covenant of the League of Nations Adopted by the Peace Conference at Plenary Session, April 28, 1919, 13 (1919) AJIL Sup. 128.

Treaty of Peace between the United States of America, the British Empire, France, Italy, and Japan, and Poland, signed at Versailles, June 28, 1919, 225 CTS 412.

Treaty of Peace with Germany, signed at Versailles on June 28, 1919, 13 (1919) AJIL Sup. 151.

Convention between Greece and Bulgaria respecting Reciprocal Emigration, signed at Neuillysur-Seine, November 27, 1919, 1 LNTS 67.

Treaty of Peace between Belgium, the British Empire, China, Cuba, Czechoslovakia, France, Greece, the Hedjaz, Italy, Japan, Poland, Portugal, the Serb-Croat-Slovene State, Siam and the United States, and Bulgaria, signed at Neuilly-sur-Seine. November 27, 1919, 225 CTS 332.

Treaty of Peace between the Allied Powers and Turkey, signed at Sèvres on August 10, 1920, 15 (1921) AJIL Sup. 179.

Treaty of Friendship between Russia and Turkey, Moscow, March 16, 1921, 118 BFSP 990.

Agreement with a View to Promoting Peace, with Protocol relating thereto, Protocol concerning Its Coming into Force, and Exchange of Notes, signed at Angora, October 20, 1921, 54 LNTS 177.

Convention concerning the Exchange of Greek and Turkish Populations, and Protocol, signed at Lausanne, January 30, 1923, 32 LNTS 75.

Declaration relating to the Administration of Justice, signed at Lausanne, July 24, 1923, 36 LNTS 161.

Protocol relating to Certain Concessions Granted in the Ottoman Empire, signed at Lausanne, July 24, 1923, 28 LNTS 203.

Treaty of Peace, signed at Lausanne, July 24, 1923, 28 LNTS 11.

Treaty with Turkey and Other Instruments Signed at Lausanne July 24, 1923, 18 (1924) AJIL Sup. 1.

Declaration relating to the Settlement of Refugees in Greece and the Creation for this Purpose of a Refugees Settlement Commission, signed on behalf of Great Britain, France and Italy at Geneva, September 29, 1923, 20 LNTS 41.

Convention regarding the Final Settlement of the Questions resulting from the Application of the Treaty of Lausanne and of the Agreement of Athens relating to the Exchange of Populations, signed at Ankara, 10 June 1930, 108 LNTS 233. 
Convention relating to the International Status of Refugees, signed on October 28, 1933, 159 LNTS 3663.

Pact of Balkan Entente, and Protocol-Annex, signed at Athens, February $9^{\text {th }}, 1934,153$ LNTS 154.

Universal Declaration of Human Rights, GA Res. 217A (III), UN Doc. A/810 at 71 (1948).

Geneva Convention relative to the Protection of Civilian Persons in Time of War of August 12, 1949, 75 UNTS 287.

Convention relating to the Status of Refugees, signed at Geneva, on 28 July 1951, 189 UNTS 150.

Treaty of Friendship and Collaboration, signed at Ankara, on February 28, 1953, 167 UNTS 21.

Draft Code of Crimes against the Peace and Security of Mankind, 51 UN GAOR Supp. (No. 10) at 14, U.N. Doc. A/CN.4/L.532 (1996). 


\section{TABLE OF CASES}

Case of the S. S. "Wimbledon" (United Kingdom v. Japan) PCIJ Rep. Series A No. 1 (1923).

German Settlers in Poland, Advisory Opinion, PCIJ Rep. Series B No. 6 (1923).

Exchange of Greek and Turkish Populations (Lausanne Convention VI, January 30 ${ }^{\text {th }}$, 1923, Article 2), Advisory Opinion, PCIJ Rep. Series B No. 10 (1925).

Interpretation of Article 3, Paragraph 2, of the Treaty of Lausanne (Frontier between Turkey and Iraq), Advisory Opinion, PCIJ Rep. Series B No. 12 (1925).

Case Concerning Certain German Interests in Polish Upper Silesia (The Merits) (Germany v. Poland) PCIJ Rep. Series A No. 7 (1926).

The Case of the S. S. "Lotus” (France $v$. Turkey) PCIJ Rep. Series A No. 10 (1927).

Jurisdiction of the European Commission of the Damube between Galatz and Braila, Advisory Opinion, PCIJ Rep. Series B No. 14 (1927).

Island of Palmas (Netherlands $v$. United States) 2 RIAA 829 (1928).

Rights of Minorities in Upper Silesia (Minority Schools) (Germany v. Poland) PCIJ Rep. Series A No. 15 (1928).

Interpretation of the Greco-Turkish Agreement of December 1", 1926 (Final Protocol, Article IV), Advisory Opinion, PCIJ Rep. Series B No. 16 (1928).

Case Concerning the Factory at Chorzón (Claim for Indemnity) (Merits) (Germany v. Poland) PCIJ Rep. Series A No. 17 (1928).

Monasteries of Mount Athos Case [1929] ADPILC 315.

Case Concerning the Payment of Various Serbian Loans Issued in France (France $v$. Kingdom of the Serbs, Croats, and Slovenes) PCIJ Rep. Series A No. 20 (1929).

Case Concerning the Payment in Gold of Brazilian Federal Loans Contracted in France (France v. Brazil) PCIJ Rep. Series A No. 21 (1929).

The Greco-Bulgarian “Communities”, Advisory Opinion, PCIJ Rep. Series B No. 17 (1930).

Apostolidis v. Turkish Government [1931] ADPILC 312.

Legal Status of Eastern Greenland (Denmark v. Norway) PCIJ Rep. Series A/B No. 53 (1933). 
Case Concerning the Polish Agrarian Reform and the German Minority (Application for the Indication of Interim Measures of Protection) (Germany v. Poland) PCIJ Rep. Series A/B No. 58 (1933).

Minority Schools in Albania, Advisory Opinion, PCIJ Rep. Series A/B No. 64 (1935).

The "Société Commerciale de Belgique" (Belgium v. Greece) PCIJ Rep. Series A/B No. 78 (1939).

Case Concerning East Timor (Portugal v. Australia) [1996] ICJ Rep. 90. 


\section{LIST OF ABBREVIATIONS}

ADPILC - Annual Digest of Public International Law Cases

AIDI - Annuaire de l'Institut de droit international

AJIL - American Journal of International Law

AJIL Sup. - American Journal of International Law Supplement

ASIL Pd. - American Society of International Law Proceedings

BFSP - British Foreign and State Papers

BYIL - British Year Book of International Law

CTS - The Consolidated Treaty Series

EJIL - European Journal of International Law

HILJ - Harvard International Law Journal

ICJ Rep. - International Court of Justice Reports

ICLQ - International and Comparative Law Quarterly

JHIL - Journal of the History of International Law

LQR - Law Quarterly Review

LNOJ - League of Nations Official Journal

LNTS - League of Nations Treaty Series

NYUJILP - New York University Journal of International Law and Politics

PCIJ Rep. - Permanent Court of International Justice Reports

RCADI - Recueil des cours de l'Académie de droit international de La Haye

RDILC - Revue de droit international et de législation comparée

RGDIP - Revue générale de droit international public

RIAA - Reports of International Arbitral Awards

TGS - Transactions of the Grotius Society

UNTS - United Nations Treaty Series

YJIL - Yale Journal of International Law

ZaöRV - Zeitschrift für ausländisches öffentliches Recht und Völkerrecht 


\section{NOTE ON TRANSLATION AND TRANSLITERATION}

Readers familiar to the study of Near Eastern history and politics will be accustomed to large doses of diacritics, as they will to inconsistencies in translation and transliteration from one text to the next. In that which follows, I have aimed for simplicity by favouring usages common to modern Turkish. Thus, I prefer "paşa" to the English "pasha", "vilâyet" to the Arabic "wilāyah", and so on. I have, however, made exceptions in the case of recognizable place names, where I usually follow English-language practice rather than contemporary or contemporaneous usages in other languages, Greek, Turkish, or otherwise. Hence, I write "Izmir" rather than "İzmir" or "Smyrna", "Xanthi” rather than "Xánthi” or "İşkeçe", and so on.

In keeping with most international legal and political materials prior to and contemporaneous with the Greek-Turkish population exchange, I have generally used "Turkey" and the "Ottoman Empire" interchangeably. I have, of course, made an exception to this rule when discussing matters specific to the Ottoman Empire or the Republic of Turkey, as I have when discussing the former's succession by the latter. In all such cases, the context explains my preference. It should be noted, though, that the Ottomans referred to their multi-lingual, multiconfessional state only rarely as "Turkey", and then most often in the context of diplomatic exchanges with European states or when writing for European audiences.

I have generally used the French versions of treaties and other international acts and agreements prior to the First World War, and the English versions of treaties and other international acts and agreements after the First World War.

I have generally left French-language materials in the original. However, I have translated or made use of existing translations in all cases involving Turkish-language materials. I have generally adopted the same approach in respect to German-language materials. 


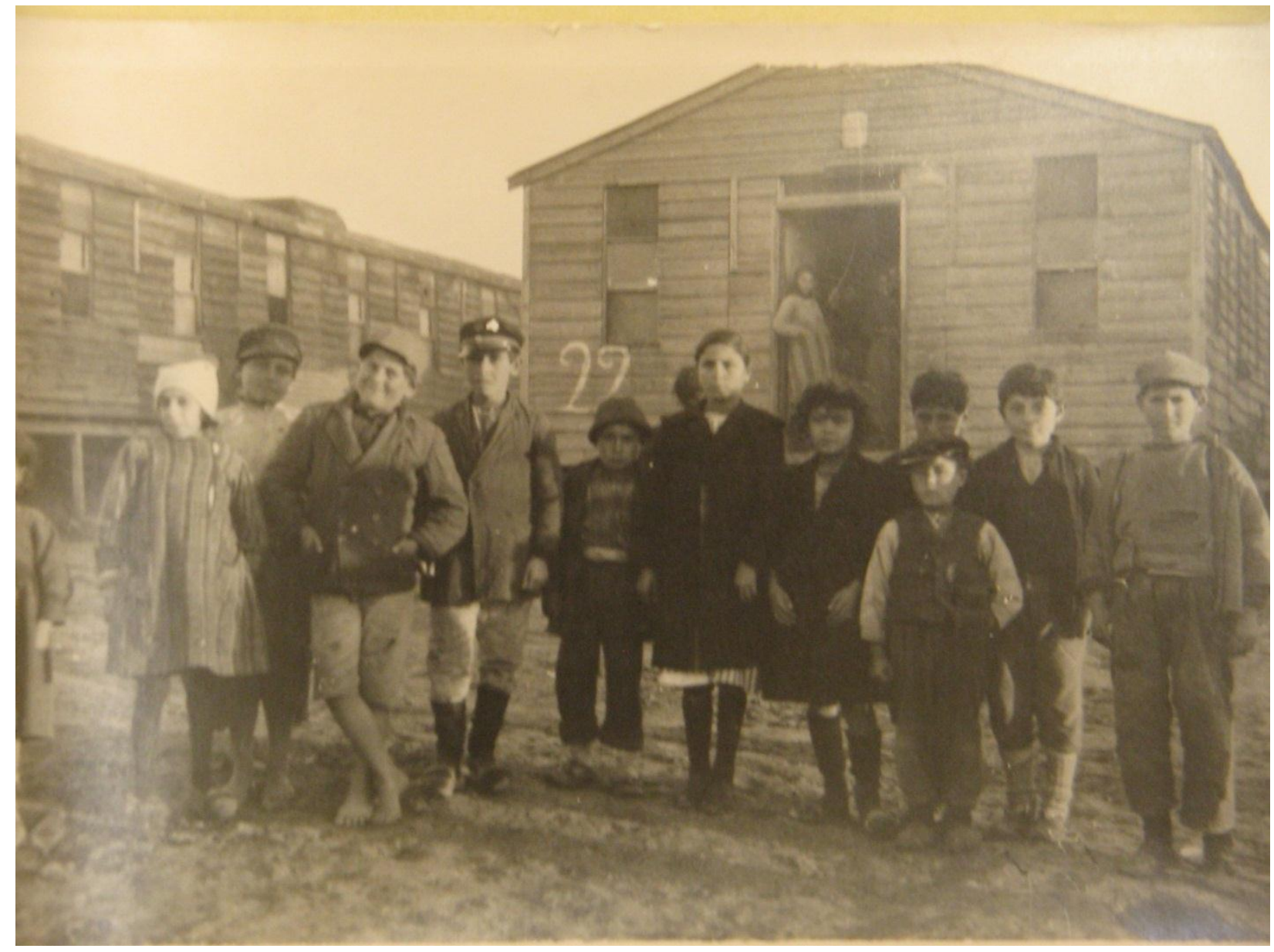

A camp for refugees from Asia Minor, likely in Greek Macedonia. Box 1, folder entitled "Refugees"; William S. Moore Photograph Collection, 1922-4, Rare Book and Manuscript Library, Columbia University in the City of New York. Reproduced with permission. 
"The exchange of commodities begins where communities have their boundaries, at their points of contact with other communities, ...."

Karl Marx, Capital: A Critique of Political Economy, Volume One, tr. Ben Fowkes (London: Penguin Books, 1990 [1867]) at 182. 


\section{INTRODUCTION}

In the fall of 1922, some three years after the commencement of the Paris Peace Conference, Fridtjof Nansen left for Istanbul. He went as League of Nations High Commissioner for Refugees, having persuaded authorities in Geneva to broaden his mandate to include Greeks displaced by war in Asia Minor. Once settled in the city, then under Allied occupation, he wrote to Eleftherios Venizelos, until recently prime minister of Greece and still a leading figure in European diplomatic circles, to propose measures for the resettlement of Greek refugees. Among these proposals was a comprehensive exchange of populations between Greece and Turkey, which Nansen described as being "within the scope of the mission with which the League of Nations" had entrusted him. ${ }^{1}$ Venizelos replied swiftly, asking the distinguished Norwegian to speak to Turkish officials with a view to laying the groundwork for a formal exchange.

Nansen was a natural choice for the job. A seasoned diplomat with extensive experience in the Near East, ${ }^{2}$ he would receive the Nobel Peace Prize later in 1922 for his efforts to secure asylum for refugees fleeing war in Russia and Asia Minor. ${ }^{3}$ As the League's first High Commissioner for Refugees, he seemed to be the ideal person to design and supervise a comprehensive exchange of the sort envisioned by Greek, Turkish, and west European authorities alike. But Nansen left for Istanbul not simply as a decorated representative of the "international community". Having achieved fame for his daring expeditions to Greenland and the Arctic, ${ }^{4}$ conducted groundbreaking research in zoology and oceanography during his first

\footnotetext{
${ }^{1}$ Quoted in Roland Huntford, Nansen: The Explorer as Hero (London: Duckworth, 1997) at 526.

2 In this dissertation, I use "Near East" in roughly the same sense in which it was generally employed at the time of the Greek-Turkish exchange, i.e. as a geographical term primarily denoting the Balkans and Asia Minor. The term is both orientalist, having gained wide currency in late nineteenth-century Europe in connection with the "Eastern Question", and notoriously ambiguous, with a range of application that fluctuates radically from one source to another. But it captures many of the assumptions held by those involved in or commenting upon the exchange, and so I have chosen to retain it.

${ }^{3}$ For his speech, see Fridtjof Nansen, "The Suffering People of Europe” in Nobel Lectures: Peace, 1901-1925, Vol. I, ed. Fredrick W. Haberman (Amsterdam: Elsevier, 1972) 361.

${ }^{4}$ See Fridtjof Nansen, Vers le Pôle, tr. Charles Rabot (Paris: Ernest Flammarion, 1897); J. Arthur Bain, Life and Adventures of Nansen, the Great Arctic Explorer (London: The Walter Scott Publishing Co., 1897). Nansen himself would write a history of earlier expeditions to the North, weaving fable and mythology together with historical record: see In Northern Mists: Arctic Exploration in Early Times, Two Vols., tr. Arthur G. Chater (London: William Heinemann, 1911).
} 
career as a natural scientist, ${ }^{5}$ made a name for himself as a monarchist in his native Norway, ${ }^{6}$ and subsequently embarked upon a political career, first as Norwegian envoy to London and then with the League, ${ }^{7}$ he was a polymath with formidable organizational talents. He had used these talents to assist Russian, Armenian, and Assyrian refugees after the First World War, ${ }^{8}$ creating a new travel document (the "Nansen passport") for displaced persons in the process." Now he would see to it that the Greek-Turkish War of 1919-22, a conflict that had nearly brought the British Empire to blows with Bolshevik Russia, was resolved peacefully.

Nansen was not entirely comfortable with the notion of a compulsory exchange. The coercive mechanisms it was bound to call forth ran counter to his identity as a "Great Humanitarian" and "Citizen of Mankind". ${ }^{10}$ Although the causes he deemed worthy of support were not always laudable - he had backed the tsar's attempt to counter the influence of the "yellow race" in eastern Siberia ${ }^{11}$ - he generally preferred the "soft power" of behind-the-scenes bargaining to the "hard power" of state-sanctioned force. While cutting his political teeth in Christiania in the early 1900s, for instance, he had lauded Norway and Sweden for dissolving their union by way of a plebiscite in words that foreshadowed his later involvement in the Near East: "The most important event in the history of the two countries" had "been settled without a single drop of blood having been shed", a possible indication that the world was "gradually advancing in culture and civilisation". ${ }^{12}$ Ultimately, though, Nansen would end up coordinating much of the exchange between Greece and Turkey. What others denounced as immoral, even illegal, he came to see as necessary for a pragmatic solution to a potentially catastrophic crisis -

\footnotetext{
5 See, e.g., Fridtjof Nansen, ed., The Norwegian North Polar Expedition, 1893-1896: Scientific Results, Six Vols. (Christiania: Jacob Dybwad, 1900-5).

${ }^{6}$ P. J. Noel Baker, "Nansen and Norway" in J. Howard Whitehouse, ed., Nansen: A Book of Homage (London: Hodder and Stoughton, 1930) 83 at 92-3.

7 See, e.g., Kathleen E. Innes, The Story of Nansen and the League of Nations (London: Friends Peace Committee, 1931).

${ }^{8}$ For his own account, see Fridtjof Nansen, Armenia and the Near East (London: George Allen \& Unwin, 1928). For analysis, see in particular Dzovinar Kévonian, Réfugiés et diplomatie bumanitaire. Les acteurs européens et la scène procheorientale pendant l'entre-deux-guerres (Paris: Publications de la Sorbonne, 2004), esp. at 298-315.

9 The Nansen International Office for Refugees, formed by the League in 1930 to provide assistance to refugees and remaining in operation until 1938, would receive the Nobel Peace Prize in 1938 for playing a crucial role in furthering acceptance of the passport. See Michael Hansson, "L’Office international Nansen pour les réfugiés sous l'autorité de la Société des Nations" 1 (1938) Le Nord 181.

${ }^{10}$ Henry Goddard Leach, "Fridtjof Nansen" 14 (1948) University of Kansas City Review 167 at 167, 173.

${ }^{11}$ Fridtjof Nansen, Through Siberia, the Land of the Future, tr. Arthur G. Chater (London: William Heinemann, 1914) at 352-3, ch. 16 generally.

${ }^{12}$ Fridtjof Nansen, Norway and the Union with Sweden (London: Macmillan, 1905) at 153.
} 
a means, as he himself put it, of achieving a "true pacification of the Near East". ${ }^{13}$ Shuttling between cities for months prior to the 1922-3 Conference of Lausanne, at which a peace settlement with Turkey would be concluded, he would immerse himself in nearly every facet of the endeavour, from its initial design through to its final implementation.

Nansen's voyage to Istanbul was both symbolically charged and logistically pivotal. But he was no thaumaturge, and what is of interest in his expedition is not its "heroism", or even the influence it enabled him to wield over the exchange with his personal charisma and professional competence. Rather, it is the fact that it encapsulated, in a kind of précis, a much broader mission to reconstitute Greece and Turkey in accordance with imperatives of order and progress. From Europe's northwesternmost tip to its southeasternmost extremity, Nansen would go to calculate and taxonomize his way into an "unmixed" Near East. ${ }^{14}$ In his train would follow a barrage of others. Humanitarian organizations - some formed to facilitate Nansen's earlier efforts, some, like Near East Relief, with deep roots in Anglo-American missionary movements ${ }^{15}$ - would be involved in many aspects of the process. A number of Western governments, most prominently Britain and the United States, would provide financial and political support for the enterprise. And a new international civil service, centred in the League of Nations' Geneva headquarters but with tentacles extending to Paris, London, New York, and elsewhere, would be tasked with overseeing important facets of the operation. These and other agents and institutions worked with authorities in Greece, as well as with a local Turkish nationalist elite (the members of which are generally, and for the most part justifiably, lumped together under the banner of "Kemalism") that was intent on transforming the multiconfessional state apparatuses it had inherited from its Ottoman predecessor into a fully "modern" Turkish nation-state. Convinced that such a state would be possible only with a much greater degree of homogeneity than Ottoman traditions of cosmopolitanism had permitted, most members of this elite supported the compulsory exchange as a means of overcoming Turkey's "backwardness".

As far-reaching as the institutional machinery marshalled for the exchange turned out to be, the legal questions it raised were no less gargantuan. Could international law be brought to

\footnotetext{
${ }^{13}$ See infra Chapter III note 10 and accompanying text.

${ }^{14}$ The term was one of which he was fond; see, e.g., Roland Huntford, Fridtjof Nansen and the Unmixing of Greeks and Turks in 1924 (Oslo: Norwegian Academy of Science and Letters, 1999) at 8.

${ }^{15}$ The best first-hand account is James L. Barton's Story of Near East Relief (1915-1930): An Interpretation (New York: Macmillan, 1930).
} 
bear upon an internecine conflict which had already claimed the lives of hundreds of thousands, and which threatened to reignite conflicts on a pan-European scale? Were its material and symbolic resources potent enough to restructure an environment as complex as the postOttoman Near East? If the increasingly institutionalized international law of the time was up to the task, did this mean that international law had itself come of age, that it was now less the abstract conceptual edifice denounced by its critics and more the supple agent of progress lauded by its supporters?

Reconstituting whole nations and states was not, of course, anything new. Even the notion of a population exchange was not entirely unknown to pre-First World War international lawyers. Long before he would appear before the Permanent Court of International Justice in a dispute arising from the Greek-Turkish exchange, a young Nicolas Politis observed that during the 1897 Greek-Turkish War, fought over Crete, the Ottomans had had recourse to mass expulsion of their Greek citizens, a measure which may have "tombée en désuétude" over the years but which was nevertheless "licite à la condition d'être exercée humainement". ${ }^{16}$ To be sure, no exchange had ever been undertaken on anything approaching the level envisioned here. And even celebrated instruments of international humanitarian law like the 1907 Hague Convention lacked provisions clearly and specifically prohibiting population transfers. ${ }^{17}$ But experience had been gained with voluntary, small-scale transfers and exchanges in the Balkans, and the idea of a compulsory procedure had been floated now and then. Indeed, as noted by Carl Schmitt - who saw Turkey's "reckless ... nationalization of the country" as evidence that "actual democracy" demands the "eradication of heterogeneity" - partition and manipulation of territory in accordance with principles like cujus regio ejus religio had distinguished the European land order - and the international legal order it threw up - since at least the Reformation. ${ }^{19}$

\footnotetext{
${ }^{16}$ Nicolas Politis, La guerre gréco-turque au point de vue du droit international: contribution à l'étude de la question d'Orient (Paris: A. Pedone, 1898) at 21.

17 An absence which, ironically enough, the Red Cross would later attribute to transfers having by then been expunged from "civilized" warfare. Jean Pictet, ed., La Convention de Genève relative à la protection des personnes civiles en temps de guerre (Genève: Comité international de la Croix-Rouge, 1956) at 9. But see also M. Cherif Bassiouni, Crimes against Humanity: Historical Evolution and Contemporary Application (Cambridge: Cambridge University Press, 2011) at 381-2.

18 Carl Schmitt, The Crisis of Parliamentary Democracy, tr. Ellen Kennedy (Cambridge, MA: The MIT Press, 1988 [1923]) at 9. See also Carl Schmitt, Constitutional Theory, tr. and ed. Jeffrey Seitzer (Durham: Duke University Press, 2009 [1928]) at 262.

${ }^{19}$ Carl Schmitt, The Nomos of the Earth in the International Law of the Jus Publicum Europaeum, tr. G. L. Ulmen (New York: Telos, 2003 [1950]) at 128.
} 
Yet here, in Greece and Turkey, in the very heart of what nineteenth-century jurists and statesmen had termed the "Eastern Question", international lawyers would be pushed to new limits. In 1906, as president of a "Balkan Committee" convened by the British Parliament, John Westlake was already exasperated with the situation: "extreme misgovernment in Turkey is a nuisance to the neighbouring European States", he wrote, adding that "if the Sultan cannot keep order in his own dominions, or if to keep order he has recourse not to civilised means of repression but to massacre, he loses all claim to be regarded as a ruler to whom international law can apply". ${ }^{20} \mathrm{By}$ the time the terms of the Greek-Turkish population exchange were concluded in early 1923, it had become obvious that minority protection, as developed by the Concert of Europe during the nineteenth century and refined in the hands of the Allies after 1919, was not going to be enough to "civilize" the Near East. A new batch of protective mechanisms would, admittedly, be introduced for minorities. But something else, a "more radical remedy" to "minority problems", 21 was necessary if the region was to have peace and prosperity. It was no less clear, however, that this "more radical remedy" could not take the form of a top-to-bottom reconstitution of whole economies, societies, and legal systems - a reconstitution of the type that had been undertaken in many corners of the colonial world. The reason for this, though simple, was crucially important: while politically and economically dependent upon the West, the Ottoman Empire had never been colonized sensu stricto, and Turkish nationalists would not permit anything that smacked of out-and-out colonialism.

As a via media solution of sorts, the population exchange thus steered a course between two extremes. On the one hand, there was the typical European scenario: minority protection in an equilibrated state system that was underwritten by a general background commitment to uti possidetis juris. On the other hand, there was the standard colonial case of total renovation, the sort of case exemplified most brutally in the sordid history of the "Congo Free State". Between the two - between a European centre and a colonial, or neo-colonial, periphery - is what occurred after the Great War in Greece and Turkey, long an unstable region on the semiperiphery of the international legal system and now wracked by the dissolution of the Ottoman

\footnotetext{
${ }^{20}$ John Westlake, "The Balkan Question and International Law" 60 (1906) The Nineteenth Century and After 889 at 892. See also Arthur G. Symonds, "The Balkan Committee 1905-1913” in Memories of John Westlake (London: Smith, Elder \& Co., 1914) 107 at $110 \mathrm{ff}$.

21 A. A. Pallis, "The Exchange of Populations in the Balkans" 97 (1925) The Nineteenth Century and After 376 at 377.
} 
land order. ${ }^{22}$ This was a unique region - neither European nor entirely non-European, neither at the centre nor at the periphery of the international legal system. Nothing less than an equally unique response would do.

\section{Organization of the Dissertation}

The goal of this study is to demonstrate that the Greek-Turkish population exchange constituted a key episode in the cultivation of a particular species of international legal nationbuilding in the first decades of the twentieth century. ${ }^{23}$ As the first legally structured compulsory endeavour of its scale and sophistication, the sheer ambition of the exchange was staggering: over one million Greeks (or those identified as such) were uprooted from Asia Minor and eastern Thrace immediately before and during the formal exchange, which began in 1923 and ran through the remainder of the decade, and something in the vicinity of 350,000 Muslims were expelled from Greece's mainland and islands over the same stretch of time. ${ }^{24}$ The formal

22 In this dissertation, I employ the terms "centre", "periphery", and "semi-periphery" in reference to different positions occupied by states in the international order. In so doing, I am, of course, broadly indebted to world systems theory. For the classic articulation, see Immanuel Wallerstein, The Modern World-System: Capitalist Agriculture and the Origins of the European World-Economy in the Sixteenth Century (New York: Academic Press, 1974); Immanuel Wallerstein, The Modern World-System, II: Mercantilism and the Consolidation of the European World-Economy, 1600-1750 (New York: Academic Press, 1980); Immanuel Wallerstein, The Modern World-System, III: The Second Era of Great Expansion of the Capitalist World-Economy, 1730s-1840s (San Diego: Academic Press, 1989); and, more recently, Immanuel Wallerstein, The Modern World-System, IV: Centrist Liberalism Triumphant, 1789-1914 (Berkeley: University of California Press, 2011). It should be noted that the concept of the semi-periphery has recently begun to gain currency in international legal scholarship. See especially Arnulf Becker Lorca, "Universal International Law: Nineteenth-Century Histories of Imposition and Appropriation" 51 (2010) HILJ 475; Umut Özsu, "Agency, Universality, and the Politics of International Legal History" 51 (2010) HILJ Online 58.

23 Though the terms "nation-building" and "state-building" are often used interchangeably, they are distinct, both in denotation and in connotation. The former is usually employed in connection with efforts to craft new identities for a given "people", while the latter is ordinarily taken to involve the refoundation of a state's institutions, often by way of external imposition. I prefer "nation-building" in this dissertation, but use it broadly to refer to both sets of processes. I do so chiefly because of their inherence in a common programme of Westernization-cummodernization in Turkey, a programme which did not lend itself to cut-and-dry distinctions of the Gemeinschaft/Gesellschaft variety: modification of the powerful state tradition the Turkish Republic inherited from the Ottoman Empire was frequently regarded as inseparable from the project of manufacturing a new (initially Ottoman, then Turkish) national consciousness. On the complex historical interrelationship of "nation-building" and "state-building", see especially Istvan Hont, “The Permanent Crisis of a Divided Mankind: 'Nation-State' and 'Nationalism' in Historical Perspective" in Istvan Hont, Jealousy of Trade: International Competition and the Nation-State in Historical Perspective (Cambridge, MA: Harvard University Press, 2005) 447.

24 Authorities have long disagreed on the numbers. For various estimates, see, e.g., Raoul Blanchard, "The Exchange of Populations between Greece and Turkey" 15 (1925) Geographical Review 449 at 449, 452-6; L'établissement des réfugiés en Grèce (Genève: Publications de la Société des Nations, 1926) at 12-3; Stephen P. Ladas, The Exchange of Minorities: Bulgaria, Greece and Turkey (New York: Macmillan, 1932) at 437-42; Frederic C. Shorter, "The Population of Turkey after the War of Independence" 17 (1985) International Journal of Middle East Studies 417 
exchange negotiated at Lausanne followed the expulsion of large numbers of Greeks and others from Asia Minor and eastern Thrace in 1922, and has therefore sometimes been presented as simply an endorsement of an already existing reality. ${ }^{25}$ This is deeply misleading: not only did the formal exchange call for entirely new movements (nearly all 350,000 Muslims and roughly 200,000 of the concerned Greeks), but it lent the full weight of international legal legitimacy to those movements which had already occurred, establishing a comprehensive legal regime to organize relief and resettlement efforts. More than two months of negotiations were needed before Turkey and the Allied Powers were able to agree on the terms of the exchange, and all parties invested heavily in the talks. This was an exercise both in producing new facts on the ground and in juridifying the dispossession and displacement that had already taken place.

The exchange showcased the new pragmatism of the post-First World War international order, an increased willingness on the part of lawyers and politicians alike to adapt legal doctrine to local conditions, bringing greater, more sophisticated institutional resources to bear on crafting functionally suitable solutions to pressing problems. ${ }^{26}$ The chief aim here was not to organize plebiscites, channel self-determination claims, or install protective mechanisms for under-resourced or under-represented minorities - all important aspects of the Allies' management of imperial disintegration in Europe after 1919. Nor was it to restructure all facets of a given economy and society in order to generate an entirely new legal system; this had often been the case with colonialism in Asia and Africa, and would characterize much of the League's system of mandates. Instead, the aim of the Greek-Turkish exchange was to reshape the demographic composition of the Near East, aligning ethnos with demos as tightly as possible, with the help of a mechanism that was tailored to the region at hand. If Greece and Turkey were to be refashioned by way of a compulsory exchange, a mechanism whose status under international law was imprecise but with which many lawyers were nevertheless willing to work,

at 425; Kemal Ar1, Büyük Mübadele: Türkiye’ye Zorunlu Göcs (1923-1925) (İstanbul: Tarih Vakf1 Yurt Yayınlar1, 1995) at 113; Renée Hirschon, "The Consequences of the Lausanne Convention: An Overview" in Renée Hirschon, ed., Crossing the Aegean: An Appraisal of the 1923 Compulsory Population Exchange between Greece and Turkey (New York: Berghahn, 2003) 13 at $14-5$.

${ }^{25}$ For a classic case, see Joseph B. Schechtman, European Population Transfers 1939-1945 (New York: Oxford University Press, 1946) at 17.

${ }^{26}$ For an attempt to map the terrain as a general shift to pragmatic institution-building among American and European jurists, see David Kennedy, “The Move to Institutions” 8 (1987) Cardozo Law Review 841. Cf. Thomas Skouteris, The Notion of Progress in International Law Discourse (The Hague: T. M. C. Asser, 2010), chs. 2, 3. 
this was in no small part due to the semi-peripheral character of the Near East, which both permitted and demanded reliance on a distinct procedure.

In developing and substantiating this argument, I attend both to international dynamics and to developments within the specific locality with which I am concerned - namely Turkey. ${ }^{27}$ And I proceed in four stages. First, I provide a sweep of the history of the international law of minority protection. The nation-building project the population exchange facilitated was carried out against the background of a tradition of minority protection fostered by the nineteenthcentury Concert of Europe system and furthered by early twentieth-century experiences with League-sponsored minority governance. I trace this law's development from its classical origins in the 1814-5 Congress of Vienna, through the balance-of-power treaties concluded during the remainder of the nineteenth century, and finally to the minority protection mechanisms introduced into a number of newly created or reconfigured states, Turkey included, after the First World War. The nineteenth-century intra-European treaty created minorities where none had existed (or been perceived to exist) and crafted fresh entitlements for them where they were already recognized, in both cases typically with an eye to balancing the interests of competing powers. Minority treaties backed by the Allied Powers after the Great War were driven by similar commitments, but were designed under different conditions and with more in the way of institutional firepower to support their efforts. The post-Ottoman Near East posed serious challenges here, in that neither a minority treaty nor a set of minority protection provisions inserted into a peace treaty were believed to be enough, in and of themselves, to ensure stability. Ultimately, the minority protection mechanisms that were introduced into Turkey via the postwar settlement were not only comparatively weak (their application was limited to non-Muslims and the entitlements they enshrined were less forceful than was the case elsewhere), but also conditioned on a compulsory population exchange between Greece and Turkey. If much of what motivated minority protection, from the early nineteenth to the early twentieth century,

\footnotetext{
${ }^{27}$ It hardly needs mentioning that the exchange's implications for nation-building in the Near East could also be studied from a specifically Greek standpoint. This dissertation focuses on Turkey not simply for reasons of access, but because the challenges confronting nation-building in Turkey were in some ways arguably more complex than in Greece, which, having existed as a constitutional monarchy for nearly a full century prior to the exchange, was not required to submit to a post-imperial transition of the kind that Turkey undertook. Nevertheless, that Greece took in a larger number of refugees - comprising a full quarter of its population at the time - is obviously anything but insignificant.
} 
was a commitment to manage ethno-nationalism, the exchange was the extension of this commitment to a context deemed too explosive for conventional instruments alone.

Second, I offer a brief discussion of the Greek-Turkish exchange's immediate antecedents. The exchange is sometimes presented as a sui generis development, an anomalous phenomenon with little in the way of forerunners. But this is neither accurate from a descriptive standpoint nor adequate from an explanatory one. In truth, the exchange demands extensive contextualization, the specific socio-historical milieu in which it was conceived and executed having deep roots in a number of earlier experiments in the Near East. Forced migrations in the final decades of the nineteenth and first decades of the twentieth century had exacerbated tensions between the Ottoman Empire's constituent ethno-confessional groups, fuelling secessionism within non-Muslim communities and mobilizing ever larger numbers of TurkishMuslim officers and bureaucrats around a common vision of a centralized, ethnically Turkish state. Transfers and exchanges were arranged between a variety of Muslim and Christian communities in the Balkans and Asia Minor during the 1910s in order to cope with unexpected migrations or facilitate movements where none would otherwise have occurred. In the process, these transfers and exchanges spurred the growth of a distinct body of international treaty law. By examining the Greek-Turkish exchange's legal and political background, one gains an understanding of its roots in late Ottoman governmental practice and also of its indebtedness to a body of treaty law whose specific aim was to juridify and engineer large-scale population movements.

Third, I look at the text and travaux préparatoires of the convention by which the exchange was governed - a convention annexed to the Lausanne Peace Treaty as a key element of the package of international legal instruments that comprised the general peace settlement between Turkey and the Allied Powers in $1923 .^{28}$ Reading statements by Lord Curzon, İsmet Paşa, and others during the Conference of Lausanne, ${ }^{29}$ I explain the convention's role in

\footnotetext{
${ }^{28}$ For the text of the exchange convention, see Convention concerning the Exchange of Greek and Turkish Populations, and Protocol, signed at Lausanne, January 30, 1923, 32 LNTS 75. For that of the peace treaty, see Treaty of Peace, signed at Lausanne, July 24, 1923, 28 LNTS 11. For the entire package (itself often referred to simply as the "Treaty of Lausanne"), see Treaty with Turkey and Other Instruments Signed at Lausanne July 24, 1923, 18 (1924) AJIL Sup. 1.

${ }^{29}$ For the minutes in English, see Lausanne Conference on Near Eastern Affairs (1922-1923): Records of Proceedings and Draft Terms of Peace, Cmd. 1814 (London: His Majesty's Stationery Office, 1923). For the French, the language employed by most delegates, see Conférence de Lausanne sur les affaires du Proche-Orient (1922-1923). Recueil des Actes de la Conférence, Six Vols. (Paris: Imprimerie nationale, 1923).
} 
shaping the juridico-political architecture of the "new Turkey". Nearly everyone at the negotiating table agreed that the exchange would need to be undertaken with the aid of technical legal instruments requiring little if any direct engagement with ethno-nationalism. This, however, did not prevent them from also drawing upon - and thereby legitimizing - this same ethno-nationalism. Crucially, the principal locus of this strained engagement with ethnonationalism was the question of how the exchange would bear upon the legal status of nonMuslims in the new Turkish Republic. The minority protection instruments that had become largely pro forma in central and eastern Europe after the First World War were thought to be insufficient to ensure order. And those being developed in connection with extra-European mandates were believed to be incompatible with conditions in Turkey. Recourse was thus had to the compulsory exchange, a mechanism which would keep the risk of majority-minority conflicts to an absolute minimum and whose roots in the Near East, with its own set of embedded legal and political practices, were apparent to all delegates at Lausanne.

Fourth and finally, I turn to the international organizations that structured and surveilled the exchange. The League of Nations was the dominant force here. And it was Nansen who was responsible for most of its involvement, acting as an intermediary between Greek and Turkish authorities and also between these authorities and League officials. No less important, though, were the humanitarian organizations which oversaw relief and resettlement efforts and with which Nansen's office maintained close contact. Many of these organizations boasted strong ties to missionary groups that had been active on Ottoman soil for some time; they employed analogous techniques, understood themselves to be engaged in similar work, and, perhaps most revealingly, were often viewed by local actors as motivated by essentially the same type of civilizing mission. Significantly, much the same commitment to contain ethnonationalist conflict also came to the fore in a 1925 advisory opinion issued by the Permanent Court - itself one of the most innovative international institutions of the period - in regard to "les établis", 30 ethnic Greeks originally exempted from the exchange on account of their status as residents of Istanbul but later asked to leave Turkey due to uncertainty relating to the date from which their residence was to be calculated. Through close analysis of the way in which it broached the status of "les établis", I demonstrate that the Court drew a sharp distinction

${ }^{30}$ Exchange of Greek and Turkish Populations (Lausanne Convention VI, January 30 ${ }^{\text {th }}$, 1923, Article 2), Advisory Opinion, PCIJ Rep. Series B. No. 10 (1925). 
between domestic and international law, bypassing Turkish concerns about the exchange's implementation so as to shield as much of Istanbul's Greek enclave as possible from the exchange. In doing so, the Court contained ethno-nationalism at a critical juncture in the exchange's implementation in a structurally homologous way to that whereby the humanitarians who poured into the Near East before and during the exchange sought to "civilize" it.

Considered as a totality, then, this dissertation examines the Greek-Turkish population exchange as the crucible within which a unique mode of nation-building first gained widespread legal currency. The interbellum was a time for programmatic, often highly imaginative, projects of nation-building. During and after the Second World War, when, ironically, population transfers became a staple of statecraft, international lawyers like Brierly could be found arguing that "[1] aw never creates order", since "the most it can do is to help to sustain order when that has once been firmly established". ${ }^{31}$ Interwar jurists, however, were generally more willing to attribute constitutive force to international law. Its rules and principles were not simply secondorder reflections of existing states of affairs - or socially, politically, and economically agnostic instruments with which such states might be modified. Rather, they were powerful, resilient forces in their own right, equipped to recast whole states and regions if necessary. When backed up by treaty, shuffling whole communities from one place to another, whether by consent or by coercion, displayed and reinforced this constitutive power.

Of course, controversy surrounded population transfers and exchanges from the very outset. Most interwar jurists were sceptical of their legality. The influential Robert Redslob, for example, branded them political, and not legal, solutions to the so-called "problème des nationalités". ${ }^{32}$ Some spoke of the exchange mechanism as "une régression regrettable dans l'évolution du droit des gens", 33 or as contrary to "l'évolution diplomatique, doctrinale et jurisprudentielle du droit des gens". ${ }^{34}$ Others noted with despair that the compulsory procedure departed from established European techniques like plebiscites and the "right of option", i.e. the right of people inhabiting territories transferred from one sovereign to another to choose between retaining their existing nationalities (in which case they would be expected to move)

\footnotetext{
${ }^{31}$ J. L. Brierly, The Outlook for International Law (Oxford: Clarendon Press, 1944) at 74.

32 Robert Redslob, Le principe des nationalités: les origines, les fondements psychologiques, les forces adverses, les solutions possibles (Paris: Sirey, 1930) at 168.

33 C. G. Ténékidès, "Le statut des minorités et l'échange obligatoire des populations gréco-turques” 31 (1924) RGDIP 72 at 86.

34 Stelio Séfériadès, "L’échange des populations” 24 (1928-IV) RCADI 307 at 331.
} 
and becoming nationals of the new sovereign (in which case they would remain where they were). ${ }^{35}$ The "brutale mesure d'expulsion et d'émigration forcées" ignored such experiences, they argued, falling foul of the "principes élémentaires qui sont à la base du droit public des nations civilisées". ${ }^{36}$

Some jurists and policymakers differed in their assessment, however, and were willing to recognize even overtly compulsory exchanges as legal, though not necessarily desirable. They might claim that the Greek-Turkish enterprise was partly an outgrowth of Turkish nationalism, a product of Turkey's desire to liquidate its minorities "complètement et radicalement" by ensuring that members of its Greek minority would be "éloignées de partout et pour toujours, sans laisser de vestige". ${ }^{37}$ But they would not dispute its legal credentials. Writing for the Permanent Court, Huber, for example, stated that the exchange was governed by a binding international treaty and that the issue at hand therefore "involve[d] a question of international law"; the question of the treaty's legality, or even legitimacy, was simply not on the table. ${ }^{38}$ British authorities in mandate-era Palestine were so impressed by the endeavour that they too would entertain an exchange. Whereas formerly "the Greek and Turkish minorities had been a constant irritant", the Peel Commission's final report declared, the "ulcer has been clean cut out" now, placing relations between the two states on much firmer footing. ${ }^{39}$ Sentiments of this kind would grow only stronger over time.

Despite such differences of opinion, or perhaps precisely because of them, the constitutive power of the Greek-Turkish exchange, its capacity to generate viable nation-states from the rubble of the Ottoman Empire, was only rarely questioned. Whether the formal exchange was understood to flout or to conform to prevailing international legal norms, that it flowed from a multilateral treaty intended to channel and constrain ethno-nationalism through regionally specific means was widely appreciated. If Turkey was sufficiently "civilized" to render untenable the sort of ambitious supervision the mandates system would necessitate, it was also not sufficiently "civilized" to do with minority protection alone.

\footnotetext{
35 Of the contexts to which the leading contemporaneous study found this right inapplicable, foremost was that of reciprocal emigration, "une voie radicale pour arriver à une solution du problème des minorités nationales". Joseph L. Kunz, "L'option de nationalité" 31 (1930-I) RCADI 107 at 134.

36 Alexandre Devedji, L'échange obligatoire des minorités grecques et turques en vertu de la convention de Lausanne du 30 janvier 1923 (Paris: Imprimerie du Montparnasse et de Persan-Beaumont, 1929) at 84, 83-7 generally.

${ }^{37}$ Franz de Jessen, "L'échange des populations turques et grecques" 5 (1923) RGDIP 510 at 514.

38 Exchange of Greek and Turkish Populations, supra note 30, at 17.

39 Palestine Royal Commission, Report, Cmd. 5479 (London: His Majesty's Stationery Office, 1937) at 390.
} 
Methodologically the parameters of this study are defined largely by those streams of postrealist socio-legal theory generally associated with the work of Pierre Bourdieu. Following Bourdieu, I approach law neither as a policy instrument nor as a formal system but as a "social space", 40 a distinct arena of action that both defines and is defined by competition between different actors wielding different quantities and qualities of social capital. As such, I examine international law from a historical and sociological rather than a normative or philosophical standpoint, offering a micro-analysis of international law's actual operation in a particular context at a particular juncture with a view to illuminating a crucial episode in the international legal history of nation-building. ${ }^{41}$

To be sure, like any other form of law, international law is capable of being utilized as a "tool". Likewise, it may under certain conditions lend itself to analysis as a formal system distinguished by internal coherence and immanent rationality. But for the purposes of the project that I undertake in this dissertation, international law is best understood as a "field of power", a "gaming space in which those agents and institutions possessing enough specific capital (economic or cultural capital in particular) to be able to occupy the dominant positions within their respective fields confront each other using strategies aimed at preserving or transforming ... relations of power". 42 This is an approach which, as one public lawyer has

40 Pierre Bourdieu, "The Force of Law: Toward a Sociology of the Juridical Field”, tr. Richard Terdiman, 38 (1987) Hastings Law Journal 805 at 828, 831, 852.

${ }^{41}$ Recent years have seen a resurgence of interest in the Greek-Turkish exchange among social and political historians. See especially Hirschon, Crossing the Aegean, supra note 24; Müfide Pekin, ed., Yeniden Kurulan Yasamlar: 1923 Türk-Yunan Zorunlu Nüfus Mübadelesi (İstanbul: İstanbul Bilgi Üniversitesi Yayınları, 2005); Onur Yıldırım, Diplomacy and Displacement: Reconsidering the Turco-Greek Exchange of Populations, 1922-1934 (New York: Routledge, 2006). However, informed legal analysis of its terms is exceedingly hard to come by. One overview can be found in Michael Barutciski, "Les transferts de populations quatre-vingts ans après la Convention de Lausanne" (2003) 41 Canadian Yearbook of International Law 271. For analysis of Lausanne from the standpoint of self-determination, see Catriona J. Drew, "Population Transfer: The Untold Story of the International Law of Self-Determination", Ph.D. dissertation, University of London (2005) at 93-110. As detailed below, I engage with self-determination only tangentially, as I am not persuaded that it offers the most illuminating lens for explicating the population exchange as a distinct mode of nation-building. What made this mechanism distinctive, particularly in the present context, was not the fact that it showed up unsavoury features of self-determination - a concept whose status under the international law of the period was somewhat nebulous. Instead, it was the fact that this mechanism deviated both from minority protection and from neo-colonialism of the mandatory variety - and in a way that can be appreciated only through close attention to the socio-cultural and politico-economic characteristics of the context at hand.

42 Pierre Bourdieu, The State Nobility: Elite Schools in the Field of Power, tr. Lauretta C. Clough (Stanford: Stanford University Press, 1996) at 264-5. This follows from a general relationship Bourdieu establishes between fields, 
recently put it, examines law as a "vernacular language" that is "generated through usage", not so much a "mechanism for determining judgments about conduct" - whether in the form of a pragmatically useful "tool" or in that of an abstract normative order - as "a practice within which criteria about right conduct are elicited". ${ }^{43}$ And unlike other, broadly comparable forms of international legal theory, ${ }^{44}$ it foregrounds questions of power, seeing conflict and (often gross) disparities in resource distribution where they see dialogue and (more or less) free and equal exchange.

The approach I adopt here departs, then, both from legal instrumentalism and from legal formalism. But it also borrows from them in some important respects. Considered from a Bourdieusian perspective, law is not an epiphenomenal superstructure, erected on the back of "deeper" relations of domination, economic or otherwise. Nor is it a citadel of irreproachable rules and principles, essential ingredients of a closed order whose objectivity flows from a reason that is both ahistorical and apolitical. The former approach misses the specificity of law altogether, according it little more than a vague capacity for "mirroring" some set of extra-legal phenomena. ${ }^{45}$ The latter mistakes a particular matrix of structures, often highly idiosyncratic, for necessary and universal features of law as such. ${ }^{46}$ What is needed, therefore, is an account of law as a social "field", one whose constitutive "logic is determined" in great part by "the specific power relations which give it its structure" but is not so thoroughly determined by these relations as to simply do away with "the internal logic of juridical functioning which constantly constrains the range of possible actions". 47 Such an account would offer an explanation of law which, on the one hand, roots it in relations of domination without reducing it to them, and, on the other hand, illuminates the force of its formal structures without absolutizing them. Law, for Bourdieu, is at one and the same time constraining and enabling, a field whose defining structures steer action in particular ways, but do so without extinguishing agency tout court.

matrices of action relationally structuring different social positions, and what he terms babitus, the internalized dispositions with which agents manoeuvre within these fields. Bourdieu introduces this terminology to overcome the conventional social scientific divide between objectivist structuralism and subjectivist phenomenology. See, e.g., Pierre Bourdieu, Outline of a Theory of Practice, tr. Richard Nice (Cambridge: Cambridge University Press, 1977 ) at 84.

${ }^{43}$ Martin Loughlin, The Idea of Public Law (Oxford: Oxford University Press, 2003) at 30 (emphasis mine).

44 I am thinking in particular of a powerful, if still diffuse, vein of constructivism in recent international legal theory. For the most sophisticated articulation to date, see Jutta Brunnée and Stephen J. Toope, Legitimacy and Legality in International Law: An Interactional Account (Cambridge: Cambridge University Press, 2010).

45 Bourdieu, "Force of Law", supra note 40, at 814.

46 Pierre Bourdieu, Pascalian Meditations, tr. Richard Nice (Stanford: Stanford University Press, 2000) at 94.

47 Bourdieu, "Force of Law", supra note 40, at 816. 
Though armed with embedded structures of practice ("rules of the game" for which every "player" is endowed with an ordinarily unthematized "feel" 48 , it is shot through with conflict between agents whose capacity for strategizing and manoeuvring remains considerable. Agents internalize the discursive and normative structures with which the legal field is buttressed, embodying them in new dispositions. Such inculcation is rarely, however, so exhaustive as to snuff out subjectivity pure and simple. ${ }^{49}$

Apart from its independent merits as a methodology for the study of law, what makes this approach especially useful for this dissertation is its ability to explain the factual production and legal framing of the Greek-Turkish population exchange. The Near East's reconstruction recruited an astonishingly wide range of actors - lawyers, diplomats, bureaucrats, clergymen, military officers, and others. Some saw themselves as part of a broader civilizing mission, bringing stability to a region that, admittedly, had not known it for some time. Nansen was particularly celebrated in this regard - and understandably so given the ambit of his influence. ${ }^{50}$ Others understood the exchange to be an opportunity to realize particular aspirations they had nursed for years. Most members of the Kemalist elite, for instance, were convinced that it was only through ethno-national homogeneity that the foundations of a viable post-Ottoman order could be established in the Near East. ${ }^{51}$ Still others bore conflicting commitments. Regardless of where they stood, though, every such agent operated within a shared legal field. This field distributed resources for articulating demands and preferences in legal terms unevenly, limiting the options available to individuals and groups quite severely in many circumstances. But it also offered opportunities for strategic appropriation and redeployment of these same resources, opening the field up to rival avenues of action. The population exchange was fashioned through

\footnotetext{
48 Pierre Bourdieu, The Logic of Practice, tr. Richard Nice (Stanford: Stanford University Press, 1990) at 66-7 ff.

49 In adopting this approach, I place somewhat greater weight on agency than Bourdieu himself, who generally prioritizes the constraining power of social structures. Bourdieu takes this line because of his insistence on the methodological-epistemological primacy of a sharp break with pre-reflexive commitments to "free action" and "full consciousness". See, e.g., Pierre Bourdieu, Jean-Claude Chamboredon, and Jean-Claude Passeron, The Craft of Sociology: Epistemological Preliminaries, ed. Beate Krais and tr. Richard Nice (Berlin: Walter de Gruyter, 1991) at 15, 17; Pierre Bourdieu and Loïc J. D. Wacquant, An Invitation to Reflexive Sociology (Chicago: University of Chicago Press, 1992) at 10-1, 123-40. I share Bourdieu's intuition that "common sense" intentionalism is unsustainable. But in this dissertation, I grant more importance to self-understanding and strategic insight, not least because Turkish authorities displayed a remarkable capacity for strategic and tactical deliberation while negotiating and executing the population exchange.

50 See especially the discussion in Chapter IV.

51 See especially the discussion in Chapters II and III.
} 
interactions between differentially situated agents competing over lopsidedly allocated ideological and institutional resources.

This approach has significant consequences for the detailed account I give in this dissertation of the role of actors and institutions external to the Near East in the exchange. The great powers were instrumental in designing and executing the exchange, acting in and through the League of Nations' constituent organs and a variety of humanitarian organizations. The League had implanted minority protection regimes throughout central and eastern Europe after 1919 in an effort to forestall majority-minority conflicts resulting from sweeping redistributions of sovereign power. Since this was thought insufficient in the Near East, recourse was had to the compulsory exchange, a more radical and explicitly coercive measure with roots in the region's recent past that most believed "would have been impossible in Central-Europe". 52 But, as will be shown below, while each of the concerned states and international organizations worked within this common framework, they sometimes adopted different approaches or emphasized different concerns. Some threw their weight more or less exclusively behind the claim that the exchange was driven by the demands of a world in which technocracy had begun to dominate both the form and the content of international relations - and life more generally. ${ }^{53}$ The Great War had shown up the limits of cosmopolitanism; if a region as volatile as the Near East was to survive, let alone thrive, in this new world, it would need to be parcelled into discrete, easily manageable units. Others chose to foreground its overtly humanitarian aspirations: the West had done precious little to rescue Armenians from genocide, ${ }^{54}$ and it could ill afford to stand by and watch as Greeks and Turks (whether self-identified or externally characterized as such) razed whole provinces. Ultimately, both the exchange and the Turkish

52 Erwin Loewenfeld, "The Protection of Private Property under the Minorities Protection Treaties" 16 (1930) TGS 41 at 41.

53 Indeed, it is arguable that it was only in the interwar period that "the economy" came to the fore as a distinct, ostensibly unitary object of technical expertise. Timothy Mitchell, "The Work of Economics: How a Discipline Makes Its World” 46 (2005) European Journal of Sociology 297 at 298.

54 I use the term "genocide" throughout this dissertation when discussing the systematic deportations and massacres of 1915, as I am convinced that, anachronism notwithstanding, no other term is legally adequate and politically responsible. From a growing literature demonstrating the existence of an intent to annihilate the Armenian presence in Anatolia on the part of key members of the late Ottoman political elite, see especially Donald Bloxham, The Great Game of Genocide: Imperialism, Nationalism, and the Destruction of the Ottoman Armenians (Oxford: Oxford University Press, 2005); Taner Akçam, A Shameful Act: The Armenian Genocide and the Question of Turkish Responsibility, tr. Paul Bessemer (New York: Metropolitan Books, 2006); Fuat Dündar, Crime of Numbers: The Role of Statistics in the Armenian Question (1878-1918) (New Brunswick, NJ: Transaction, 2010); Ronald Grigor Suny, Fatma Müge Göçek, and Norman M. Naimark, eds., A Question of Genocide: Armenians and Turks at the End of the Ottoman Empire (Oxford: Oxford University Press, 2011). 
state it created came to serve as the repository for these and other approaches, a condensate of the prolonged competition that was waged over its juridico-political architecture.

Equally, this approach has important implications for my account of the Turkish nationalists' role in the exchange - though here the story is less one of plurality and shiftiness and more one of unity and consistency. The vast majority of the Kemalist elite, a militant cadre of modernizers, were deeply committed to the exchange, consenting to it, and the comprehensive recalibration of Turkish law and society it entailed, in the name of a broader programme of nation-building. Securing the new state's borders, homogenizing its population, and extending Ankara's authority over the length and breadth of the territory it had inherited from its imperial predecessor were, it was assumed, necessarily interrelated, part and parcel of the modernization project to which the Kemalists had dedicated themselves. If post-Ottoman Turkey was to bootstrap itself into modernity through defensive Westernization, displacing an old noblesse d'épée with a new noblesse d'état and thereby transitioning from a predominantly dynastic to a fully bureaucratic state,${ }^{55}$ it could do so only by deploying more modern techniques of legal organization. Yet, it is not possible to understand this general commitment, this shared set of background assumptions regarding the nature and demands of statehood, without explaining the way in which leading members of the Turkish nationalist movement juggled competing pressures and commitments in an effort to superimpose their own ambitions onto a large, unorganized peasantry. ${ }^{56}$ As Bourdieu himself might have put it, the Turkish Republic's construction proceeded "apace with the construction of a field of power, defined as the space of play within which the holders of capital (of different species) struggle in particular for power over

\footnotetext{
${ }^{55}$ Pierre Bourdieu, "From the King's House to the Reason of State: A Model of the Genesis of the Bureaucratic Field" in Loïc Wacquant, ed., Pierre Bourdieu and Democratic Politics: The Mystery of Ministry (Cambridge: Polity, 2005) 29 at 40, 44, 50. It should be noted, though, that the Ottoman state boasted well-resourced bureaucratic apparatuses, with impressive recruitment standards, traditions of institutional independence, and levels of administrative efficiency and procedural harmonization, as early as the seventeenth century. See especially Rhoads Murphey, Exploring Ottoman Sovereignty: Tradition, Image and Practice in the Ottoman Imperial Household, 1400-1800 (London: Continuum, 2008), ch. 9. These apparatuses were subject to considerable expansion, consolidation, and differentiation in the first half of the nineteenth century, when new ministries (including ministries of justice and foreign affairs) were established. For sustained treatment, see Carter V. Findley, Bureaucratic Reform in the Ottoman Empire: The Sublime Porte, 1789-1922 (Princeton: Princeton University Press, 1980) at 167-90. Indeed, it is arguably precisely this superabundance of state power that made it possible for Marx and Engels to speculate about "Oriental despotism" and "the Asiatic mode of production". Halil Berktay, "Three Empires and the Societies They Governed: Iran, India and the Ottoman Empire" in Halil Berktay and Suraiya Faroqhi, eds., New Approaches to State and Peasant in Ottoman History (London: Frank Cass, 1992) 242 at 253.

${ }^{56}$ Cf. Georgi M. Derluguian, Bourdien's Secret Admirer in the Caucasus: A World-System Biography (Chicago: University of Chicago Press, 2005) at $78 \mathrm{ff}$.
} 
the state, that is, over the statist capital granting power over the different species of capital and over their reproduction". 57

Writing from a Bourdieusian perspective, Yves Dezalay and Bryant Garth have examined the workings of international commercial arbitration, the exportation of European and American legal and economic reforms to Latin America, and the key roles played by lawyers in state-building projects in several east and south Asian societies. ${ }^{58}$ Nicolas Guilhot has looked at the way in which US foreign policy and the agendas of US-centred human rights organizations have been formulated through competition between different groups of lawyers and policymakers - some established, others upwardly mobile. ${ }^{59}$ Still others influenced by Bourdieu have studied the transnational governance instruments produced by the post-1989 wave of legal transplants ${ }^{60}$ or focused on changes to criminal jurisdiction and the legal definition of terrorism after 11 September 2001. ${ }^{61}$ This dissertation engages and builds upon this body of scholarship with a view to developing a finer appreciation of a classic episode in the international legal history of nation-building. Only a micro-analytical account of the sort that Bourdieusian socio-legal theory permits can explain the legal and political infrastructure of the Greek-Turkish exchange in a way that is adequate to its complexity, historical significance, and ongoing resonance.

\section{Distinguishing the Problematic}

That the Greek-Turkish exchange is the locus classicus of a distinct form of nation-building has important implications for the terms under which I engage with international legal doctrine and scholarship. The first such implication relates to the international law of self-determination; the second concerns the multiple legal sources for Turkey's nation-building project. In distinct but

\footnotetext{
${ }^{57}$ Pierre Bourdieu, "Rethinking the State: Genesis and Structure of the Bureaucratic Field", tr. Loï J. D. Wacquant and Samar Farage, in Pierre Bourdieu, Practical Reason: On the Theory of Action (Stanford: Stanford University Press, 1998) 35 at 42 (emphases in original).

58 See, respectively, Dealing in Virtue: International Commercial Arbitration and the Construction of a Transnational Legal Order (Chicago: University of Chicago Press, 1996); The Internationalization of Palace Wars: Lawyers, Economists, and the Contest to Transform Latin American States (Chicago: University of Chicago Press, 2002); Asian Legal Revivals: Lawyers in the Shadow of Empire (Chicago: University of Chicago Press, 2010).

59 Nicolas Guilhot, The Democracy Makers: Human Rights and the Politics of Global Order (New York: Columbia University Press, 2005).

${ }^{60}$ David M. Trubek et al., "Global Restructuring and the Law: Studies of the Internationalization of Legal Fields and the Creation of Transnational Arenas” 44 (1994) Case Western Reserve Law Review 407.

${ }^{61}$ See the articles in 173 and 174 (2008) Actes de la recherche en sciences sociales.
} 
related ways, both involve issues arising from Turkey's unique experience as a former imperial power situated on the margins of Europe - a state with a strained, but distinctly non-colonial, relationship with the international law generated by Europe over the preceding centuries.

At first glance, self-determination may strike one as a promising lens with which to analyze the exchange. It cannot, after all, be denied that various conceptions of selfdetermination - Leninist, Wilsonian, and others - figured prominently in negotiations surrounding the dissolution and creation of states after the First World War - and even less that a diffuse fascination with the broader and still vaguer "principle of nationalities" was in circulation at the time. I am not, however, concerned with the international law of selfdetermination as such in this dissertation.

To begin with, though it may have been ubiquitous both as a legal notion and as a political slogan, no single vision of self-determination had secured enough support to warrant characterization as an international legal norm by the time of the exchange. Ethnicity and other categories were used widely as criteria for redrawing borders, reshuffling domestic legal arrangements, or manufacturing entirely new states, but self-determination itself did not belong to general international law, at least not clearly or uncontroversially. ${ }^{62}$ Indeed, self-determination has a notoriously rocky past. At first, in the late nineteenth and early twentieth centuries, a "principle", legally under-determined and limited in application to Europe and certain portions of the Americas, and subsequently, with increasing vibrancy after the Second World War and especially with the decolonization and national liberation movements of the 1950s and 1960s, a "right", an independent source of entitlement and obligation, self-determination's status has arguably never been fixed. ${ }^{63}$ Indeed, though one can find support for its legality in state practice

\footnotetext{
62 The classic reference is "Report of the International Committee of Jurists Entrusted by the Council of the League of Nations with the Task of Giving an Advisory Opinion upon the Legal Aspects of the Aaland Islands Question", 3 (1920) LNOJ Spec. Sup. 3 at 5 (stating that "Positive International Law does not recognize the right of national groups, as such, to separate themselves from the State of which they form part by the simple expression of a wish, any more than it recognizes the right of other States to claim such a separation"). For recent commentary, see especially Antonio Cassese, Self-Determination of Peoples: A Legal Reappraisal (Cambridge: Cambridge University Press, 1995) at 27, 33; Karen Knop, Diversity and Self-Determination in International Law (Cambridge: Cambridge University Press, 2002) at 63 ff. For contemporaneous discussion, see Sarah Wambaugh, Plebiscites since the World War, with a Collection of Official Documents, Vol. I (Washington: Carnegie Endowment for International Peace, 1933) at 41.

${ }^{63}$ For sweeps, see Ian Brownlie, "An Essay in the History of the Principle of Self-Determination" in C. H. Alexandrowicz, ed., Grotian Society Papers 1968: Studies in the History of the Law of Nations (The Hague: Nijhoff, 1970) 90; Joshua Castellino, International Law and Self-Determination: The Interplay of the Politics of Territorial Possession with Formulations of Post-Colonial "National" Identity (The Hague: Nijhoff, 2000) at 7-43.
} 
and World Court jurisprudence, ${ }^{64}$ it is not entirely settled whether self-determination can even now be said to possess the normative weight requisite to qualify as lex lata - or, in the event that it can, to whom exactly the "right" it makes available attaches. ${ }^{65}$

Additionally, the Kemalists themselves were suspicious of self-determination. With Wilsonian promises of an independent Armenia and Kurdistan still fresh in their minds, few Turkish nationalists had any intention of allowing self-determination - at least that subversive, secessionist vein often affiliated with Rousseauian romanticism ${ }^{66}$ - to exert as much influence in Lausanne as it had in Paris and London three years earlier. True, they did occasionally draw on the rhetoric of self-determination. ${ }^{67}$ But even then they nearly always relied on a variant geared towards Lenin's Petrograd rather than Wilson's Washington; the latter's interpretation of selfdetermination was regarded by many at the time as simply a form of divide et impera. ${ }^{68}$ And this was not without basis: "As for the Turks", noted a contemporaneous historian and diplomat, "the world is little disposed to allow self-determination to peoples of the Moslem faith" ${ }^{69}$ No account of the Greek-Turkish exchange which hopes to capture the concrete historical context

64 The ICJ conferred on self-determination the status of an erga omnes obligation in Case Concerning East Timor (Portugal $v$. Australia) [1996] ICJ Rep. 90 at 102 - this in spite the fact that stateless peoples hoping to draw upon self-determination still have no locus standi in the Peace Palace. For commentary, see Draft Articles on Responsibility of States for Internationally Wrongful Acts, with Commentaries, in Report of the International Law Commission on the Work of Its Fifty-Third Session, UN GAOR, 56 th Sess., Supp. No. 10, UN Doc. A/56/10 (2001) at 85, 111, 113, 127. For a good synthetic discussion, see David Raič, Statehood and the Law of SelfDetermination (The Hague: Kluwer, 2002) at 218-9.

${ }^{65}$ See, e.g., Michla Pomerance, Self-Determination in Law and Practice (The Hague: Nijhoff, 1982) at 68 ("No State has accepted the right of all peoples to self-determination" (emphasis in original)); Richard Gittleman, "The African Charter on Human and Peoples' Rights - A Legal Analysis" 22 (1982) Virginia Journal of International Law 667 at 680 (distinguishing those "not qualified to be included under the rubric 'people' permitted to exercise the right of selfdetermination").

${ }^{66}$ See, e.g., Martti Koskenniemi, "National Self-Determination Today: Problems of Legal Theory and Practice" 43 (1994) ICLQ 241 at 248, 256.

${ }^{67}$ For instance, for an argument to the effect that some of self-determination's defining tropes can be detected in the 1920 "National Pact", the founding charter of the Kemalist movement, see İbrahim Kaya, Social Theory and Later Modernities: The Turkish Experience (Liverpool: Liverpool University Press, 2004) at 79. For details on the "Pact", see infra Chapter II note 84 and accompanying text.

${ }^{68}$ It was the Bolsheviks, and not the Wilsonians, who insisted most forcefully on the specifically national character of self-determination, investing it with the status of a revolutionary call to arms. Erez Manela, The Wilsonian Moment: Self-Determination and the International Origins of Anticolonial Nationalism (Oxford: Oxford University Press, 2007 ) at 41. Wilson adopted a modified form of this position only after it became clear that demands for representative government were being interpreted in stronger terms by subject nationalities than he had expected. Thomas D. Musgrave, Self-Determination and National Minorities (Oxford: Oxford University Press, 1997) at 23-4. For a classic analysis of the rivalry, see Arno J. Mayer, Wilson vs. Lenin: Political Origins of the New Diplomacy, 1917-1918 (New Haven: Yale University Press, 1959).

${ }^{69}$ Albert H. Lybyer, “The Balkan Situation” 10 (1920) Journal of International Relations 404 at 405. 
and specific constellation of forces within which it unfolded can fail to acknowledge that selfdetermination - whatever its precise legal status at the time - was not its driving force.

Hence, I depart from scholarship that explores the link between self-determination and population transfer, ${ }^{70}$ and suggest that the former does not offer the most illuminating lens for examining the Greek-Turkish exchange as the crucible for a distinct mode of nation-building. What is distinctive about the population exchange mechanism, as first developed in the Near East during the 1910s and 1920s, is not the fact that it showed up the less savoury features of self-determination, often employed as an umbrella term for a broad array of disparate phenomena. Rather, it is the fact that it marked a departure both from the practice of introducing protective instruments for minorities - standard in Europe throughout the long nineteenth century and augmented considerably after 1919 - and from the practice of reconstructing entire economies and societies from scratch - the typical case of colonial and neo-colonial governance in Africa and Asia. To bear fruit in the post-Ottoman Near East, the desire to manage ethno-nationalism that underlay minority protection required something in excess of minority protection itself - but also something that stopped short of outright mandatory rule, given that none of the relevant parties deemed this a workable option for Greece and Turkey. The "something" that ultimately materialized - the population exchange was not called forth by the international law (or even political slogan) of self-determination so much as the commitment to craft a functional solution to a particularly challenging conflict which had arisen in a context framed neither as strictly European nor as strictly extra-European.

The second, closely related point flows directly from this distinctiveness. Save for brief occupations of Istanbul and segments of Anatolia immediately after the First World War, Turkey had never been subject to formal administration by a foreign power. It had, to be sure, come under the influence of Western law, both municipal and international, for some time already. In some cases, this influence had been driven by largely diplomatic processes, as with France both before and after 1789 (e.g. long-standing alliances reaching back as far as the sixteenth century, the enormous prestige bestowed upon the Code Napoléon in the nineteenth century). In others, it had run much deeper, penetrating the Ottoman Empire's politicoeconomic core (e.g. a far-reaching regime of capitulatory privileges, control of the public debt by a consortium of European creditors, German ownership and management of railroads). And

\footnotetext{
${ }^{70}$ Drew, supra note 41, esp. at 93-110.
} 
this involved many of the substantive elements of formal colonialism, engendering relations of dependency and debt-accumulation similar in many respects to those in India and elsewhere. ${ }^{71}$ By the first decades of the twentieth century, even the most penetrating scholars of imperialism could be found suggesting as much: just as Hobson warned in 1902 that most of the remaining Turkish dominions would succumb to "a slow, precarious process of absorption" (t2 (the "absorption", when it finally came, proved neither slow nor precarious), so too Lenin, strategizing laterally in 1917, would group Turkey with Persia and China in a class of "semicolonial countries". ${ }^{73}$ Nevertheless, this centuries-long encounter with the West - coming to the fore with the French-inspired Tanzimat reforms of the mid-nineteenth century and culminating in the proclamation of the Turkish Republic in 1923 - involved the incremental marginalization of an otherwise powerful patrimonial state, often through policies of its own devising, not colonialism in the strict legal sense of direct annexation and administration. ${ }^{74}$ If Ottoman Turkey had sometimes been cast as the "Sick Man of Europe", it had also styled itself the Islamic world's "Eternal State" (Devlet-i Ebed-Müddet) - what one delegate at the Conference of Lausanne itself would term "a great Islamic Power". ${ }^{75}$ It may never have been recognized as a fully fledged member of the "family of civilized nations", at least not definitively, but even the most crudely positivistic jurists felt a need to carve out an intermediate class for cases of the type it was deemed to exemplify, thereby distinguishing it from "savage" regions and terrae nullius. ${ }^{76}$ Indeed, the influential classification of "civilized", "barbarous" (or "semi-civilized”), and "savage" (or "non-civilized") states offered by James Lorimer - with Turkey as the

71 C. A. Bayly, "Distorted Development: The Ottoman Empire and British India, circa 1780-1916" 27 (2007) Comparative Studies of South Asia, Africa and the Middle East 332 at 339. See further Huri İslamoğlu and Peter C. Perdue, eds., Shared Histories of Modernity: China, India and the Ottoman Empire (London: Routledge, 2009); Richard S. Horowitz, "International Law and State Transformation in China, Siam, and the Ottoman Empire during the Nineteenth Century" 15 (2004) Journal of World History 445.

${ }^{72} \mathrm{~J}$. A. Hobson, Imperialism: A Study, 3rd Rev. Ed. (London: George Allen \& Unwin Ltd., 1938 [1902]) at 224.

${ }^{73}$ V. I. Lenin, "Imperialism, the Highest Stage of Capitalism" [1917] in Henry M. Christman, ed., Essential Works of Lenin: “What Is to Be Done?” and Other Writings (Mineola, NY: Dover, 1987) 177 at 230.

${ }^{74}$ See especially Rifa'at 'Ali Abou-El-Haj, Formation of the Modern State: The Ottoman Empire, Sixteenth to Eighteenth Centuries, $2^{\text {nd }}$ Ed. (Syracuse: Syracuse University Press, 2005) at 61-72.

${ }^{75}$ Minutes of the Territorial and Military Commission's (TMC's) meeting on 10 January 1923, in Lausanne Conference, supra note 29 , at 313,321 .

${ }^{76}$ For lucid analysis of the distinction, see Jörg Fisch, "Internationalizing Civilization by Dissolving International Society: The Status of Non-European Territories in Nineteenth-Century International Law" in Martin H. Geyer and Johannes Paulmann, eds., The Mechanics of Internationalism: Culture, Society and Politics from the 1840s to the First World W ar (Oxford: Oxford University Press, 2001) 235 at 252 ff. 
archetypal illustration of the "semi-civilized" state - was intended to convey precisely this. ${ }^{77}$ Broadly comparable to Japan or Russia, but with its own sphere of influence and somewhat closer to the periphery than either, Turkey entered the twentieth century straddling two worlds, still as uncertain of its place in the international legal order as others were unsure of its proper position. $^{78}$

Because of this distinctiveness, this dissertation does not attempt to identify one or two Western parents for Turkey's legal reconstitution through the exchange, a key element of any post-colonial critique. Nor does it try to assimilate the Turkish case to a familiar narrative of nineteenth- and early twentieth-century lawyers' attempts to craft appropriate responses to the European "problem of nationalities". Instead, it examines the processes through which shifting relations of power between a variety of actors and institutions facilitated Turkey's transition from empire to nation-state by way of the exchange.

As would be expected, this calls for parsimonious engagement with existing scholarship. Though this dissertation shares many of the political and methodological commitments of recent international legal scholarship taking its lead from the concerns of what during the Cold War was termed the Third World, ${ }^{79}$ it does not position itself as a strictly Third World-oriented analysis of interwar international law, an analysis conducted strictly from the standpoint of the international legal system's periphery. Inasmuch as the task at hand is that of capturing what was distinctive about the population exchange - what made it a mechanism arising from a particular region and with a scope of application that was initially limited to that region scholarship geared toward Third World experiences with state-building and international

${ }^{77}$ James Lorimer, The Institutes of the Law of Nations: A Treatise of the Jural Relations of Separate Political Communities, Vol. I (Edinburgh: W. Blackwood \& Sons, 1883) at 239, 444. For the ideational context that made this vision of world order possible, see Duncan Bell and Casper Sylvest, "International Society in Victorian Political Thought: T. H. Green, Herbert Spencer, and Henry Sidgwick" 3 (2006) Modern Intellectual History 207, esp. at 231-7; Jennifer Pitts, "Boundaries of Victorian International Law" in Duncan Bell, ed., Victorian Visions of Global Order: Empire and International Relations in Nineteenth-Century Political Thought (Cambridge: Cambridge University Press, 2007) 67, esp. at $72-4$.

${ }^{78}$ Perhaps the greatest structural analogies are with China, whose elites generally understood themselves to be at the centre of a universal empire even in the late nineteenth century, by which time they had been forced to conclude unequal treaties with European powers and barred by Japan from exacting tribute from Korea and other historical vassals. Cf. Yasuaki Onuma, A Transcivilizational Perspective on International Law (Leiden: Nijhoff, 2010) at $339-48$.

${ }^{79}$ For programmatic accounts, see Makau Mutua, "What is TWAIL?" 94 (2000) ASIL Pd. 31; B. S. Chimni, "Third World Approaches to International Law: A Manifesto" in Antony Anghie et al., eds., The Third World and International Order: Law, Politics and Globalization (Leiden: Nijhoff, 2003) 47. 
administration, while crucially important as an analogue, cannot serve as a basis for one-to-one comparisons.

Similarly, since this dissertation is not confined to examining the Greek-Turkish exchange in the light of the international law that was developed in and for Europe in response to the "problem of nationalities", I depart from the work of Nathaniel Berman, who has addressed many of the cultural roots and ramifications of European jurists' ambivalence in regards to nationalism. ${ }^{80}$ Berman notes rightly that population transfer was a "relatively marginal solution" to nationalist rivalry. ${ }^{81} \mathrm{My}$ task is precisely to explain why this was so - why, that is, it was this mechanism, and not some other, that had its provenance in the Near East, why it came to be applied exclusively in this region during the 1910 s and 1920 s, and what this reveals about the nature of international law at the time. This task is facilitated by the fact that I set off from a significantly different methodological standpoint than Berman does. While Berman draws mainly from cultural studies, particularly as inflected by deconstruction and psychoanalysis, ${ }^{82} \mathrm{I}$, as just outlined, ground my analysis in historical sociology and Bourdieusian social theory. This has significant consequences for the way in which I develop my argument by contextualizing the relevant treaty texts and preparatory work in social, political, and economic relations (and not cultural relations).

Because of its magnitude and its overtly coercive character, the Greek-Turkish population exchange has always strained the tolerance and imagination of international lawyers. Though often criticized, proposals for the exchange were not condemned so consistently and rigorously as to impede its implementation. Neither, for that matter, did the Greek-Turkish experience, growing out of forces and relations specific to the region, render impossible the extension of the exchange mechanism to other jurisdictions in the decades that followed. Indeed, though the

\footnotetext{
${ }^{80}$ See especially "Modernism, Nationalism, and the Rhetoric of Reconstruction" 4 (1992) Yale Journal of Law and the Humanities 351; “A Perilous Ambivalence: Nationalist Desire, Legal Autonomy, and the Limits of the Interwar Framework" 33 (1992) HILJ 353; “But the Alternative is Despair': European Nationalism and the Modernist Renewal of International Law” 106 (1993) Harvard Law Review 1792.

81 "Alternative", supra note 80, at 1845.

${ }^{82}$ For explicit discussion, see Nathaniel Berman, "Against the Wrong and the Dead: A Genealogy of Left/MPM" 22 (2001) Cardozo Law Review 1005.
} 
notion of population exchange long inhabited something of a legal no-man's-land, its status under international law being somewhat unclear, jurists and diplomats soon pressed ahead with transfers in a wide variety of locales and under a wide range of circumstances. From eastern Europe under Nazi threat and occupation during the 1930s and 1940s to the same region under Allied command immediately after 1945, from the partition of British India through Uganda's mass expulsion of south Asians to the ex post legitimation of forced migration in Cyprus and Yugoslavia, population transfer came to be deployed extensively and ambitiously. If we are to understand the legal valorization of population transfer throughout the twentieth century, and the tacit endorsement of this mechanism in some quarters even today, we must come to grips with its origins in a semi-peripheral region with a specific set of entrenched traditions and institutions. 


\section{CHAPTER I.}

\section{Governing the Ungovernable: \\ Turkey and the International Law of Minority Protection, 1815-1923}

This chapter demonstrates that the Greek-Turkish population exchange was rooted in a nationbuilding project developed against the background of an intra-European tradition of minority protection. I begin with the classic balance-of-power treaties of the nineteenth century, examining the extent to which they involved not only the extension of further entitlements to recognized minorities, but also the legal construction of minorities where none had previously been understood to exist. Both tendencies, the effort to strengthen protective mechanisms for existing minorities and the fabrication of new minorities, were, I argue, rooted in a felt need to grapple with the vagaries of ethno-nationalism - containing it where it was thought to pose a threat to the European state system, cultivating it where it could be put to use for nationbuilding purposes. This was especially pronounced in the case of the Ottoman Empire, retooling relations between the sultan and non-Muslims being a recurring feature of the Concert of Europe's conference diplomacy. Arguably the most critical aspects of the minority protection mechanisms developed by these treaties were engineered in response to the "Eastern Question". If the international legal order produced by the Concert system placed minority protection at the centre of a project of reallocating rights, authorities, and territories across and beyond Europe, it was the continent's heterogeneous southeastern margins that called for closest supervision, not least because this was a region which posed a serious threat to international stability and which deviated most markedly from emergent European norms of centralized statehood.

I then canvass the minority treaties of the post-First World War years. The new technologies of protection called forth by these treaties - the minority petition system was only the most celebrated example - overhauled state apparatuses and redistributed constitutional powers across an enormous swath of territory encircling Europe's politico-economic core, from Poland and the Baltic states in the north to Turkey (and later, though only tentatively, Iraq) in the south. The League of Nations' burgeoning international civil service was marshalled not simply for what we might now view as a typically Foucauldian project of regimenting and 
surveilling nation-state formation. ${ }^{1}$ This service was also brought to bear on the project of fashioning, implementing, and monitoring functional institutions of minority governance in regions that were not subject to mandates. The overriding goal here - a goal shared by Allied diplomats and many central and east European statespersons - was to craft regimes that would formalize ethno-nationalism without extinguishing it.

Finally, I turn briefly to the protective system that was introduced for non-Muslim minorities in post-Ottoman Turkey. Turkey bought its right to republicanism in 1923 by agreeing to certain concessions on minority protection. Chief among these was the incorporation into the Lausanne Peace Treaty of specialized provisions according Turkey's nonMuslim minority communities rights akin to those afforded minorities in central and eastern Europe after 1919. Yet these concessions were not as onerous as they have sometimes been made out to be. Their application was limited to non-Muslims, the substantive and procedural entitlements they enshrined were modest, and, most important of all, they were introduced only because the compulsory exchange with Greece, formalized at Lausanne a full half year before the signature of the final peace treaty, severely limited their applicability by deracinating much of Turkey's non-Muslim population. If "[c]onstituting states is an industry of the modern era", one that circulates as a kind of "global legal commodity" promising "a particular policy and strategy to create stability and control", 2 then it is here, in the Greek-Turkish exchange, that one finds this industry pushed beyond the minority protection instruments to which it had become accustomed in order to see its aim of managing ethno-nationalism through to the end.

\section{Minority Protection as Collective Action - The Long Nineteenth Century}

On some level, the traditional legal-historical assessment is accurate: the treaty has been "the paradigmatic instrument recognizing the right of minorities to fair treatment". ${ }^{3}$ This was

\footnotetext{
1 This, understandably, is a point on which post-colonial historians of international law have concentrated their efforts: see especially Antony Anghie, Imperialism, Sovereignty and the Making of International Law (Cambridge: Cambridge University Press, 2005), ch. 3; Balakrishnan Rajagopal, International Law from Below: Development, Social Movements and Third World Resistance (Cambridge: Cambridge University Press, 2003), ch. 3. But see also Susan Pedersen, "Back to the League of Nations" 112 (2007) American Historical Review 1091 at 1108-9.

2 Outi Korhonen, “The 'State-Building Enterprise': Legal Doctrine, Progress Narratives and Managerial Governance" in Brett Bowden, Hilary Charlesworth, and Jeremy Farrall, eds., The Role of International Law in Rebuilding Societies after Conflict: Great Expectations (Cambridge: Cambridge University Press, 2009) 15 at 15, 26.

${ }^{3}$ Patrick Thornberry, International Law and the Rights of Minorities (Oxford: Clarendon Press, 1991) at 25.
} 
certainly the case in Europe during the nineteenth century, when most of the entitlements associated with the international law of minority protection today - cultural and linguistic rights like the right to speak and school children in one's native tongue, equal access to courts and equal treatment at the hands of state institutions, and so on - were developed by treaty. The great powers of the day were busy cultivating new mechanisms to cope with the demands of colonialism and imperialism. The lease, the condominium, the protectorate - familiar instruments of nineteenth-century international law such as these were, in Lauterpacht's words, "devices of diplomacy", employed as "preparations for annexation" or offering "means of acquiring sufficient power where downright annexation was thought to be politically inexpedient". ${ }^{4}$ Minority-related provisions inserted into international treaties offered an additional set of techniques for governing from a distance, in this case for specifically European matters. Territorial realignments, common to the point of occurring with near-annual frequency in some corners of the continent, would often leave one or another community, distinct from a cultural, linguistic, or religious standpoint from its neighbours, on the wrong side of a new border. Preserving the continental balance of power was deemed paramount, and this was an end that could be achieved only if all parties could be made to keep the peace, be it through persuasion or coercion. Specially drafted treaty provisions and similar instruments were thought adequate to this task, particularly when underwritten by great power assurances of surgical intervention in the event that vulnerable communities were persecuted.

Marking the conclusion of the Napoleonic Wars, which had raised the spectre of a generalized disintegration of Europe's anciens régimes, the Congress of Vienna of 1814-5 generated a series of treaties that contained France by establishing a new regime of intraEuropean coordination that would restore the status quo ante bellum. ${ }^{5}$ In the words of Talleyrand, France's top negotiator at Vienna, it was driven by a commitment on the part of France's principal adversaries to equilibrate "the forces of resistance and the forces of aggression of the

\footnotetext{
${ }^{4}$ Hersch Lauterpacht, "International Law and Colonial Questions, 1870-1914” in International Law, Being the Collected Papers of Hersch Lauterpacht, Vol. II, ed. Elihu Lauterpacht (Cambridge: Cambridge University Press, 1975$) 95$ at 114. ${ }^{5}$ Harold Nicolson, The Congress of Vienna: A Study in Allied Unity: 1812-1822 (New York: Grove, 1946), esp. chs. 6, 14; H. G. Schenk, The Aftermath of the Napoleonic Wars: The Concert of Europe - An Experiment (New York: Howard Fertig, 1967), ch. 6; F. R. Bridge and Roger Bullen, The Great Powers and the European States System 1815-1914 (London: Longman, 1980) at 14, 28. Though a largely peripheral actor in the conflicts that followed the French Revolution, the Ottoman Empire had been destabilized by France's excursions into Egypt and eastern Europe. Paul F. Shupp, The European Powers and the Near Eastern Question 1806-1807 (New York: Columbia University Press, 1931), ch. 17.
} 
various political entities" so as to eliminate the risk of continent-wide conflicts of the kind that had been unleashed by Napoleon. ${ }^{6}$ Importantly, in addition to reshuffling extra-European possessions between Europe's more seafaring states, the congress introduced a variety of protective measures for certain subject nationalities. Thus, Article 1 of the congress' Final Act its first operative paragraph - famously stated that "[l]es Polonais, Sujets respectifs de la Russie, de l'Autriche, et de la Prusse, obtiendront une représentation et des Institutions Nationales réglées d'après le mode d'existence politique, que chacun des Gouvernements auxquels ils appartiennent jugera utile et convenable de leur accorder". ' Commentators have often sought to locate in this and related provisions the seeds of what international lawyers would later term "national minorities", and it is common to date the international law of minority protection from Vienna. ${ }^{8}$

Though important elements of the Napoleonic model of statehood would find their way into the post-Restoration period,' it was widely assumed at Vienna that continental peace, strained by the French Revolution, a powerful engine for diffusing norms of popular sovereignty, ${ }^{10}$ was capable of being reinstated and safeguarded only through synchronized action on the part of the great powers. When necessary, it was now believed, these states would need to intervene boldly to redistribute sovereign authority with a view to preserving the

\footnotetext{
${ }^{6}$ Quoted in Joachim von Elbe, "Peacemaking in 1815" 36 (1942) AJIL 470 at 473.

7 Act of the Congress of Vienna, signed between Austria, France, Great Britain, Portugal, Prussia, Russia and Sweden, 9 June 1815, 64 CTS 453 at 457.

${ }^{8}$ From a voluminous literature, see, e.g., Charles de Visscher, "Protection of Minorities" in Charles de Visscher, The Stabilization of Europe: Lectures on the Harris Foundation, 1924 (Chicago: University of Chicago Press, 1924) 27 at 33; L. P. Mair, The Protection of Minorities: The Working and Scope of the Minorities Treaties under the League of Nations (London: Christophers, 1928) at 26; C. A. Macartney, National States and National Minorities (Oxford: Oxford University Press, 1934) at 159-61; Andre Liebich, "Minority as Inferiority: Minority Rights in Historical Perspective" 34 (2008) Review of International Studies 243 at 253. Others, however, have argued that, like so many other facets of classical international law, minority protection ought to be derived from the Peace of Westphalia. See, e.g., Hurst Hannum, "The Concept and Definition of Minorities" in Marc Weller, ed., Universal Minority Rights: A Commentary on the Jurisprudence of International Courts and Treaty Bodies (Oxford: Oxford University Press, 2007) 49 at 52.

9 See especially David Laven and Lucy Riall, "Restoration Government and the Legacy of Napoleon" in David Laven and Lucy Riall, eds., Napoleon's Legacy: Problems of Government in Restoration Europe (Oxford: Berg, 2000) 1 at 8-9 ff.

${ }^{10}$ From a voluminous literature, see especially Boris Mirkine-Guetzévitch, "L’influence de la Révolution française sur le développement du droit international dans l'Europe orientale" 22 (1928-II) RCADI 295; René-Jean Dupuy, "La Révolution française et le droit international actuel" 214 (1989-II) RCADI 9; Chimène Keitner, The Paradoxes of Nationalism: The French Revolution and Its Meaning for Contemporary Nation Building (Albany: State University of New York Press, 2007), esp. ch. 4.
} 
balance of power formalized in the "public law of Europe" - a phenomenon made possible only through a certain harmonization of the identities and interests of their elites. ${ }^{11}$

The creation of an independent Greece by Russia, Britain, and France - three of the five powers comprising the core of the Concert of Europe, the others being Austria and Prussia - offers a striking, albeit extreme, example of the transformative reach of this commitment. Though reluctant to support insurrection, the three powers - under domestic pressure from democrats and socialists ${ }^{12}$ - threw their weight behind Greek insurgents agitating for independence from Istanbul. Presenting the Ottomans with an ultimatum outlining their conditions "de réconciliation et de paix", the great powers stated that they had resolved "de combiner leurs efforts, et d'en régler l'action, par un Traité formel, dans le but de rétablir la paix entre les Parties Contendantes, au moyen d'un arrangement réclamé, autant par un sentiment d'humanité, que par l'intérêt du repos de l'Europe". ${ }^{13}$ The Porte made noises of resistance in response, producing a state paper condemning intervention in its domestic affairs, ${ }^{14}$ but was ultimately forced to yield. Henceforth the Concert of Europe - centrepiece of an international order of which Europe itself was seen as the nucleus - would ensure that metropolitan rivalries and provincial rebellions alike would be managed through congress diplomacy. ${ }^{15}$ And the system would prove durable, with no less than twenty-six conferences being convened between 1822 and $1913^{16}$ - a fact that has prompted some to present Vienna as the crystallization of a

\footnotetext{
11 Some contemporaneous jurists were scathing in their assessment of this phenomenon. Consider Fiore: “C'est pour cela que dans ce meeting de dictateurs, la règle qui prévalut, fut celle de rétablir les possessions territoriales, dans l'état où elles étaient avant la Révolution française, sans tenir compte de la situation morale des différents pays, des caractères nationaux, des intérêts des peuples, et en se préoccupant uniquement des intérêts des Princes et des Dynasties." Pasquale Fiore, Nouveau droit international public suivant les besoins de la civilisation moderne, tr. Charles Antoine, $2^{\text {nd }}$ Ed., Vol. I (Paris: A. Durand et Pedone-Lauriel, 1885) at 50 (emphasis in original). The crass realism of balance of power doctrine may explain its partial disavowal by international lawyers in the late nineteenth century, when the international legal profession sought increasing autonomy and respectability. See Miloš Vec, "De-Legitimizing 'Balance of Power': Principles in International Legal Doctrine", paper presented at the $4^{\text {th }}$ Research Forum of the European Society of International Law at the University of Tartu (26 May 2011), at 12-5. Cited with permission.

12 Eric Hobsbawm, The Age of Revolution: 1789-1848 (London: Abacus, 1977 [1962]) at 146.

13 Treaty between France, Great Britain and Russia for the Pacification of Greece, signed at London, 6 July 1827, 77 CTS 307, Preamble, Art. 6, at 309, 312. Efforts to terminate “l'Affaire Grecque d'une manière durable et propre à prévenir toute discussion ultérieure sur cette question" would ultimately yield a final agreement: see Arrangement between France, Great Britain and Russia, and Turkey, for the Definitive Settlement of the Continental Boundaries of Greece, signed at Constantinople, 21 July 1832, 82 CTS 477, Preamble, at 479.

${ }^{14}$ See J. T. Abdy, ed., Kent's Commentary on International Law, $2^{\text {nd }}$ Rev. Ed. (Cambridge: Deighton, Bell, and Co., 1878) at 48-9.

15 Cf. Gerry Simpson, Great Powers and Outlaw States: Unequal Sovereigns in the International Legal Order (Cambridge: Cambridge University Press, 2004) at 67-76.

16 Bridge and Bullen, supra note 5, at 4 and also 41-2.
} 
Eurocentric world order premised on the bracketing of war within Europe and the concomitant intensification of competition for extra-European territories and resources. ${ }^{17}$

The 1856 Treaty of Paris, concluded after the Crimean War, the only conflict to reach continental proportions after the post-Napoleonic settlement, deepened and further formalized the Concert system. Of particular importance for present purposes is the fact that it altered relations between the great powers and Sublime Porte. ${ }^{18}$ Turkey gained "admission" into the European state system with this treaty, its preamble addressing the need to preserve the integrity and independence of the Ottoman Empire through "garanties efficaces et réciproques" and Article 7 famously according it the right "à participer aux avantages du droit public et du concert Européens". ${ }^{19}$ The precise legal implications of such statements were always nebulous: it was unclear, for instance, whether the Ottoman Empire could truly be said to have secured recognition as a state on the same formal footing as those comprising the Concert, or whether it had simply been subordinated to European international law as something of a semisovereign. ${ }^{20}$ But the key power-political assumptions were never anything but obvious: it was widely believed that the treaty would neutralize the Black Sea, check Russian advances in the Balkans, and transfer Russia's role as the "protector" of Turkey's non-Muslims to west European states. ${ }^{21}$

This last objective received additional support from Article 9, which noted that the sultan had already issued a decree - "spontanément émané de sa volonté souveraine" a month before the treaty's signature - reaffirming his "généreuses intentions envers les populations Chrétiens de son Empire". 22 Coming at the height of the Tanzimat, a series of reforms designed

\footnotetext{
${ }^{17}$ For two such assessments from significantly different theoretical standpoints, see Carl Schmitt, Theory of the Partisan: Intermediate Commentary on the Concept of the Political, tr. G. L. Ulmen (New York: Telos, 2007 [1975]) at 9, 49, 53; and Michel Foucault, The Birth of Biopolitics: Lectures at the College de France, 1978-79, ed. Michel Senellart and tr. Graham Burchell (Houndsmills: Palgrave Macmillan, 2008) at 59-60.

${ }^{18}$ General Treaty for the Re-Establishment of Peace between Austria, France, Great Britain, Prussia, Sardinia and Turkey, and Russia, signed at Paris, 30 March 1856, 114 CTS 409.

${ }^{19}$ Ibid., at 410, 414. Some saw the Porte as endowed with this right even before Paris: see, e.g., Robert Phillimore, Commentaries upon International Law, Vol. I (Philadelphia: T. \& J. W. Johnson, 1854) at 101.

${ }^{20}$ See, e.g., Hugh McKinnon Wood, "The Treaty of Paris and Turkey's Status in International Law" (1943) 37 AJIL 262, esp. at 269 and 273-4. Cf. Fikret Adanır, "Turkey's Entry into the Concert of Europe" 13 (2005) European Review 395.

${ }^{21}$ See, e.g., George Douglas Campbell Argyll, The Eastern Question; From the Treaty of Paris 1856 to the Treaty of Berlin 1878, and to the Second Afghan War, Vol. I (London: Strahan \& Co., 1879), ch. 1; Harold Temperley, "The Treaty of Paris of 1856 and Its Execution" 4 (1932) Journal of Modern History 523; A. J. P. Taylor, The Struggle for Mastery in Europe 1848-1918 (Oxford: Clarendon Press, 1954) at 83-6.

${ }^{22}$ Treaty of Paris, supra note 18, at 414.
} 
to modernize Turkey's legal and administrative institutions in accordance with the demands of the post-Napoleonic era, ${ }^{23}$ this decree strengthened formal equality in regards to religious expression, educational opportunity, employment in the civil service, and legal adjudication (in the last case via mixed tribunals for the adjudication of disputes involving persons of different faith). ${ }^{24}$ Christian communities in the Near East had figured prominently in relations between the Ottomans and Romanovs for some time already, making repeated appearances in the treaties the Porte had concluded with the Hermitage from the eighteenth century onwards. ${ }^{25}$ Only three years before Paris, a Russian admiral had "proposed" that the sultan extend life-term appointments to Greek Orthodox patriarchs throughout the Empire in the belief that this would both strengthen their hand against Istanbul and deepen their dependence upon Saint Petersburg. ${ }^{26}$

Paris was the culmination of these developments, and tipped the balance in favour of Britain and France. Turkey was now to be "admitted" to the system of European public law, or at least brought within its fold nominally. But this came at the price of its immersion in an increasingly far-reaching regime of control that would enable the great powers to guard Christian interests in the Empire even more rigorously than had Russia. The Ottomans had begun to be absorbed into global circuits of capital centred in northwestern Europe as early as the mid-eighteenth century. And this process had often been mediated by capitulatory arrangements which granted various forms of most-favoured-nation status (as in the final

${ }^{23}$ Roderic H. Davison's Reform in the Ottoman Empire, 1856-1876 (Princeton: Princeton University Press, 1963) remains the leading study, though Edouard Engelhardt's early work La Turquie et le Tanzimat, ou Histoire des réformes dans l'Empire ottoman depuis 1826 jusqu'a nos jours (Paris: A. Cotillon et Cie, 1882) is still useful. A brief tabulation of the legal reforms can be found in Gülnihâl Bozkurt, "Tanzimat and Law” in Tanz̨imat'in 150. Yıldönümü Uluslararası Sempozyumu: Ankara: 31 Ekim - 3 Kasim 1989 (Ankara: Türk Tarih Kurumu Basımevi, 1994) 279. For an interesting analysis of these reforms, see İlber Ortaylı, Imparatorluğun En Uzun Yüzynl (İstanbul: İletişim, 1999), ch. 5.

${ }^{24}$ For an English translation, see Firman and Hatti-Sheriff of the Sultan, relative to Privileges and Reforms in Turkey, 18 $8^{\text {th }}$ February 1856, reproduced in Edward Herslet, The Map of Europe by Treaty; Showing the Various Political and Territorial Changes Which Have Taken Place since the General Peace of 1814, Vol. II (London: Butterworth, 1875) 1243. This decree was also intended to reaffirm and bolster the reform programme outlined in the 1839 rescript which had launched the Tanzimat: see The Hattı Şerif of Gülhane, 3 November 1839, reproduced in J. C. Hurewitz, ed., Diplomacy in the Near and Middle East: A Documentary Record: 1914-1956, Vol. I (New York: Octagon, 1972) 113.

25 The most significant being a 1774 treaty concluded after the 1768-74 Russo-Turkish War and generally interpreted as having accorded Russia sweeping rights of guardianship over Christians on Ottoman territory: see Treaty of Perpetual Peace and Amity between Russia and Turkey, signed at Kuçuk Kainardji, 10(21) July 1774, 45 CTS 349, esp. Art. 7, at 390. For Russian efforts to amplify the meaning of and secure international support for these rights after the treaty's signature, see Roderic H. Davison, “'Russian Skill and Turkish Imbecility': The Treaty of Kuchuk Kainardji Reconsidered” 35 (1976) Slavic Review 463.

${ }^{26}$ M. Şükrü Hanioğlu, A Brief History of the Late Ottoman Empire (Princeton: Princeton University Press, 2008) at 7980 . 
decades of the eighteenth and first decade of the nineteenth century) or by bilateral treaty agreements which provided relatively unfettered access to Ottoman markets (as in the ultraliberal environment of the $1830 \mathrm{~s}$ and 1840s). ${ }^{27}$ The Treaty of Paris ensured that this politicoeconomic assimilation would be consolidated: not only would capitulatory privileges and immunities for non-Muslim foreigners, detailed below, remain in place, ${ }^{28}$ but the sultan would permit the creation of European-managed banks, agree to the establishment and expansion of supervisory financial institutions staffed partly by foreigners, and encourage the importation of European economic science to achieve this end. ${ }^{29}$ The paradox, as a student of the Concert system once noted, was striking: while the great powers had in some ways formally "repudiated the right of interference" in the Ottoman Empire's domestic matters, Paris was in other ways "the point at which Turkey finally passed into a state of tutelage to the European Concert". 30

Ottoman statesmen were acutely aware of the threat posed by Western encroachment, and took steps to minimize it. The wording of the crucial Article 9 of the Treaty of Paris was, for instance, the subject of some contestation, with Ottoman negotiators fiercely resisting language that may have suggested quasi-contractual obligations growing out of the sultan's decree. The great powers would not "take note of" (prendre acte) this decree, since this turn of phrase, when rendered into Turkish (as kaynd ve derhater etmek), was understood by the Sublime Porte to entail a guarantee, something permitting external supervision and enforcement. Instead, they would merely "recognize the high value" (constatent la haute valeur) of its terms; this

${ }^{27}$ Reşat Kasaba, The Ottoman Empire and the World Economy: The Nineteenth Century (Albany: State University of New York Press, 1988) at 32-4, 54-6; Immanuel Wallerstein, Hale Decdeli, and Reşat Kasaba, "The Incorporation of the Ottoman Empire into the World-Economy” in Huri İlamoğlu-İnan, ed., The Ottoman Empire and the World-Economy (Cambridge: Cambridge University Press, 1987) 88 at 92-4. The most well-known, and arguably most important, of these treaties, fixing import and export duties and imposing restrictions upon Ottoman monopolies, was the Convention of Commerce and Navigation between Great Britain and Turkey, signed at Balta-Liman, 16 August 1838, 88 CTS 77. For analysis of this and other mid-nineteenth-century treaties, see Reşat Kasaba, "Open-Door Treaties: China and the Ottoman Empire Compared" 7 (1992) New Perspectives on Turkey 71, esp. at 73-4. For cautionary remarks, however, see also Orhan Kurmuş, "The 1838 Treaty of Commerce Re-examined" in JeanLouis Bacqué-Grammont and Paul Dumont, eds., Économie et sociétés dans l'Empire ottoman, fin du XVIIIe - début du XXe siècle. Actes du colloque de Strasbourg, 1er - 5 juillet 1980 (Paris: Éditions du Centre national de la recherche scientifique, 1983) 411.

${ }^{28}$ Treaty of Paris, Art. 32, supra note 18, at 419 (precluding their renewal or replacement absent Western consent).

${ }^{29}$ Firman and Hatti-Sheriff, supra note 24, at 1248-9. For analysis, see Kasaba, Ottoman Empire, supra note 27, at 53; Edhem Eldem, "Ottoman Financial Integration with Europe: Foreign Loans, the Ottoman Bank and the Ottoman Public Debt” 13 (2005) European Review 431 at 433 ff.

${ }^{30}$ J. A. R. Marriott, The Eastern Question: An Historical Study in European Diplomacy (Oxford: Clarendon Press, 1917) at 274. 
was the most that Turkish negotiators were willing to concede. ${ }^{31}$ Nevertheless, despite such resistance, the Ottomans were clearly on their back foot. Gone were the days when the Empire could hazard the conceit of being a power confident in the eternity and eventual triumph of the dàr al-Islam and oblivious to the demands of permanent diplomacy. ${ }^{32}$ Having gained the right to partake in the European state system's "advantages", it now had to comport itself as a proper European state: a foreign ministry had been set up formally some years before Paris, and now it would be enlarged and improved, with French being adopted as its official working language, the telegraph being employed, its staff becoming increasingly professionalized, and a slate of new embassies being established in Europe and the United States. ${ }^{33}$

Finally, there is the 1878 Treaty of Berlin, a product of the last full-scale nineteenthcentury congress to involve minority protection seriously. Marking the end of the RussoTurkish War of 1877-8 and tellingly styled an agreement "for the Settlement of Affairs in the East", the Treaty of Berlin has often been regarded as the most ambitious attempt to institute a minority protection regime in the Near East prior to 1919. ${ }^{34}$ It laid out the most comprehensive set of minority guarantees to date, a development that owed much to successful lobbying on behalf of Romanian Jews by the Alliance israélite universelle. ${ }^{35}$ And it conditioned recognition of Serbia, Montenegro, and Romania as de jure sovereigns - and Bulgaria as a de facto independent state - on conformity to these guarantees. The relevant provisions were substantively identical in each case, forbidding, inter alia, discrimination on the basis of faith "en ce qui concerne la jouissance des droits civils et politiques, l'admission aux emplois publics,

31 Roderic H. Davison, "Ottoman Diplomacy at the Congress of Paris (1856) and the Question of Reforms" in VII. Türk Tarih Kongresi (Ankara: 25-29 Eylül 1970) - Kongreye Sunulan Bildiriler, Vol. II (Ankara: Türk Tarih Kurumu Basimevi, 1973) 580 at 584-5.

${ }^{32}$ Not until 1793 did the Ottomans open their first permanent embassy in Europe. (They did so in London.) J. C. Hurewitz, "Ottoman Diplomacy and the European State System" 15 (1961) Middle East Journal 141 at 145; A. Nuri Yurdusev, "The Ottoman Attitude toward Diplomacy" in A. Nuri Yurdusev, ed., Ottoman Diplomacy: Conventional or Unconventional? (Houndmills: Palgrave Macmillan, 2004) 5 at 27.

33 J. C. Hurewitz, "The Europeanization of Ottoman Diplomacy: The Conversion from Unilateralism to Reciprocity in the Nineteenth Century" 25 (1961) Belleten 455, esp. at 462-4. See also Carter V. Findley, "The Legacy of Tradition to Reform: Origins of the Ottoman Foreign Ministry" 1 (1970) International Journal of Middle East Studies 334; Carter V. Findley, "The Foundation of the Ottoman Foreign Ministry" 3 (1972) International Journal of Middle East Studies 388.

34 See, e.g., Macartney, supra note 8, at 166; Geoff Gilbert, "Religio-nationalist Minorities and the Development of Minority Rights Law” 25 (1999) Review of International Studies 389 at 401.

35 Carole Fink, Defending the Rights of Others: The Great Powers, the Jews, and International Minority Protection, 1878-1938 (Cambridge: Cambridge University Press, 2004) at 15-38; and also Moria Paz, "A Non-Territorial Ethnic Network and the Making of Human Rights Law: The Case of the Alliance Israélite Universelle" 4 (2010) Interdisciplinary Journal of Human Rights Law 1 at 7-13. 
fonctions, et honneurs ou l'exercice des différentes professions et industries dans quelque localité que ce soit". ${ }^{36}$ However, further requirements were introduced in the case of Turkey. The Porte's heavy-handedness in suppressing rebellions had raised the ire not only of Russia but also of the Western powers. ${ }^{37}$ As such, Articles 61 and 62 compelled Turkey to undertake "améliorations" and "réformes" in Armenian-populated provinces, strengthen the right to offer evidence in Ottoman courts for all its nationals, refrain from restricting the movement of pilgrims, and adopt other measures. ${ }^{38}$ Just as the conflict that had given rise to the Treaty of Berlin had been "une veritable guerre d'humanité", so too would its terms serve as illustrations of "l'intervention collective d'humanité". 39

That no such mechanisms of minority protection were mandated for the great powers was lost neither on Western commentators nor on Turkish elites. In Europe, the one-sided character of European interventionism had already established itself as a leitmotif in political and legal writing. ${ }^{40}$ Critical sentiments only received further support in Berlin's wake. Shortly after the treaty was ratified, Gladstone wrote that it was not "a little amusing to observe with what edifying zeal all the great States of Europe united to force religious liberty upon those new-fledged bantlings of politics, on their very first light of day; and yet these great States have hardly in any case learned ... to adopt it at home". ${ }^{41}$ Ottoman statesmen were alive to the

36 Treaty between Austria-Hungary, France, Germany, Great Britain, Italy, Russia and Turkey for the Settlement of Affairs in the East, signed at Berlin, 13 July 1878, 153 CTS 171, Arts. 5, 27, 35, 44, at 176 (Bulgaria), 182 (Montenegro), 184 (Serbia), 187 (Romania). As part of these stipulations, Muslims seeking to maintain residences in three of the new Balkan states were entitled to have their properties protected, partly through administration at the hands of mixed commissions. Ibid., Arts. 12, 30, 39, at 177-8 (Bulgaria), 183-4 (Montenegro), 186 (Serbia). In the case of Romania, only a general provision guaranteeing the rights possessed by "autres Puissances Européennes" to Ottoman subjects travelling through or sojourning in the country made its way into the treaty. Ibid., Art. 49, at 187.

37 A typical reaction: "The brutality reported of the Turks in Bulgaria raised throughout Europe a cry for the intervention of the Christian Powers, upon grounds of humanity and religion, - thus bringing the fervor of humane impulse and of religious enthusiasm into one of the most confused problems of international law." Joseph P. Thompson, American Comments on European Questions, International and Religious (Boston: Houghton, Mifflin \& Co., 1884) at 105. For the context, see further Richard Millman, Britain and the Eastern Question 1875-1878 (Oxford: Clarendon Press, 1979) at 450-1.

38 Treaty of Berlin, supra note 36, at 189-90.

39 André Mandelstam, La Société des Nations et les puissances devant le problème arménien (Paris: Pédone, 1926) at 17-8 (deemphasized from original).

40 For a classic example, see Giuseppe Mazzini, “On Nonintervention” [1851] in Stefano Recchia and Nadia Urbinati, eds., A Cosmopolitanism of Nations: Giuseppe Mazzini's Writings on Democracy, Nation Building, and International Relations (Princeton: Princeton University Press, 2009) 213 at 217 (denouncing the principle of non-intervention as "Intervention on the wrong side; Intervention by all who choose, and are strong enough, to put down free movements of peoples against corrupt governments").

${ }^{41}$ William E. Gladstone, The Berlin Treaty and the Anglo-Turkish Convention (London: Liberal Central Association, 1878 ) at 14. Support for non-intervention could also be found among jurists; see, e.g., Mountague Bernard, On the 
phenomenon, and had already taken numerous steps to counteract it. The 1876 Ottoman constitution (Kanûn-1 Esâsî, literally "Basic Law"), the first such document of its kind in the Empire and drafted partly in response to European pressure, ${ }^{42}$ had already included as its first and most fundamental provision a statement to the effect that the imperial polity comprised "an indivisible whole from which no part can ever be detached for any motive whatever". ${ }^{3}$ Ottoman sensitivity was heightened further by what transpired in Berlin. Saffet Paşa, Grand Vezier at the time, likened the great powers' stance during the negotiations to that which they had adopted in respect to the partitions of Poland, and an Istanbul newspaper wondered whether the "new science of ethnography" on which the treaty clearly relied would not turn the Empire into an unwieldy federation with loose administrative boundaries. ${ }^{44}$

The Treaty of Berlin and similar instruments testify to the growing strength of a distinctively European understanding of international order, one in which strategic intervention - intervention in the name of preserving the stability of the continental state system - came to be seen as increasingly valuable. As Holland wrote toward the end of the century, Berlin signified "a well-defined stage in the disintegration of the empire of the Turks in Europe, and the redistribution of power in the Balkan peninsula", transforming "into independent States the fringe of vassal provinces which encircled, on the north, the European dominions of the Ottoman Empire". ${ }^{45}$ As it turned out, the treaty did not generate genuinely effective enforcement mechanisms; it could not, for instance, prevent subsequent Romanian persecution

Principle of Non-Intervention: A Lecture Delivered in the Hall of All Souls' College (Oxford: J. H. and Jas. Parker, 1860) at 24 ff (arguing, inter alia, that "the first and highest interest of the great commonwealth of States itself is the independence of its several members").

${ }^{42}$ A fact which led Lorimer to denounce it as a political tactic: "The Corân was not violated by a promise made to the infidel to do what was impossible, and yet that promise took away from the other parties to the Treaty of Paris the last formal pretext for interference in the internal affairs of the Ottoman Empire." James Lorimer, "Does the Corân Supply an Ethical Basis on Which a Political Superstructure Can Be Raised?” [1877-8] in James Lorimer, Studies National and International, Being Occasional Lectures Delivered in the University of Edinburgh 1864-1889 (Edinburgh: William Green \& Sons, 1890) 132 at 142. Of course, as Lorimer well knew, "interference in the internal affairs of the Ottoman Empire" only intensified in the years that followed.

43 For an English translation, see The Ottoman Constitution, promulgated the 7th Zilbridje, 1293 (11/23 December, 1876) 2 (1908) AJIL Sup. 367 at 367. This constitution was short-lived, remaining in force for only two years, but would resurface in 1908, during the "second constitutional era". See infra Chapter II note 58 and accompanying text.

${ }^{44}$ Roderic H. Davison, "The Ottoman Empire and the Congress of Berlin" in Ralph Melville and Hans-Jürgen Schröder, eds., Der Berliner Kongress von 1878. Die Politike der Grossmächte und die Probleme der Modernisierung in Südosteuropa in der zweiten Hälfte des 19. Jahrbunderts (Wiesbaden: Steiner, 1982) 205 at 213.

45 Thomas Erskine Holland, "The Execution of the Treaty of Berlin" [1882], in Thomas Erskine Holland, Studies in International Law (Oxford: Clarendon Press, 1898) 226 at 250, 252. But see also William Norton Medlicott, The Congress of Berlin and After: A Diplomatic History of the Near Eastern Settlement 1878-1880 (London: Methuen \& Co., $1938)$ at $133-4$. 
of Jews ${ }^{46}$ or Ottoman repression of Armenians. ${ }^{47}$ But it did bolster the collective regime of minority protection inaugurated at Vienna and confirmed by Paris. This regime licensed even deeper intrusions than before into the domestic legal systems of eastern states - states whose status as nominal vassals of the Porte (e.g. Bulgaria) restricted them to what many German jurists termed Halbsouveränität, ${ }^{48}$ or whose formal independence (Serbia, Montenegro, and Romania) was conditioned on their recognition as subordinates in the European state system. Small wonder it became somewhat fashionable at this juncture - when fascination with the European sovereign state form ran high - to refer to sovereign equality as a principle "rapidly becoming obsolete", 49

What one finds in each of these treaties - snapshots of a diffuse and deeply conflictual process rather than foundational reference-points for a coherent body of law of the sort that Holland seems to have had in mind when speaking of a "corpus iuris publici orientalis" 50 - is a certain commitment to discipline ethno-nationalism, generally regarded as a source of instability. If a group that found itself in the position of a minority in a given state were seriously marginalized or persecuted, the international legal order produced by the Concert of Europe might well come under threat. European powers were generally unwilling to tolerate such disorder, and were prepared to police situations of actual or perceived crisis. ${ }^{51}$ Indeed, contemporaneous surveys of the Concert's interventions in the Ottoman Empire were typically quite blunt in their condemnation of Ottoman policy in regards to subject peoples and in their assessment of Ottoman statesmen's increasingly limited agency. ${ }^{52}$ Additionally, however, one

\footnotetext{
46 See, e.g., Francis Rey, "La question israélite en Roumanie" 10 (1903) RGDIP 460. For a documentary history, see Lucien Wolf, Notes on the Diplomatic History of the Jewish Question (London: Spottiswoode, Ballantyne \& Co. Ltd., 1919) at 36-45.

47 See, e.g., Gustave Rolin-Jacquemyns, "L’Arménie, les Arméniens et les traités” 21 (1889) RDILC 291. For the context, see Jeremy Salt, Imperialism, Evangelism and the Ottoman Armenians, 1878-1896 (London: Frank Cass \& Co., 1993); Vahakn N. Dadrian, The History of the Armenian Genocide: Ethnic Conflict from the Balkans to Anatolia to the Caucasus, 3 ${ }^{\text {rd }}$ Rev. Ed. (Providence: Berghahn Books, 1997), ch. 8.

${ }^{48}$ K. Omer Lutfi, Die völkerrechtliche Stellung Bulgariens und Ostrumeliens (Erlangen: E. Th. Jacob, 1903) at 24-46. See further J. H. W. Verzijl, International Law in Historical Perspective, Vol. I (Leiden: Sijthoff, 1972) at 260.

49 T. J. Lawrence, “The Primacy of the Great Powers" in T. J. Lawrence, Essays on Some Disputed Questions in Modern International Law, 2 ${ }^{\text {nd }}$ Ed. (Cambridge: Deighton, Bell \& Co., 1885) 208 at 209.

50 Thomas Erskine Holland, The European Concert in the Eastern Question (Oxford: Clarendon Press, 1885) at 2.

51 On this "policing" function, see Georges-Henri Soutou, "Le Concert européen, de Vienne à Locarno" in Jean Bérenger and Georges-Henri Soutou, eds., L'ordre européen du XVIe au XXe siècle (Paris: Presses de l'Université de Paris-Sorbonne, 1998) 117 at $122 \mathrm{ff}$.

52 A good example is provided by Edouard Engelhardt, an experienced diplomat and international lawyer: "En dehors de ces diverses initiatives que consacrent des traités publics ou des protocoles plus ou moins solennels, initiatives communes ou individuelles, par lesquelles les grandes puissances de l'Europe ont imposé leurs volontés à
} 
also finds a commitment to make minorities where none formerly existed, whether through territorial realignments, inducements for domestic reform, or shifts in alliance networks and guardianship relations. Certain communities were not aware of their "appropriate" legal status; content or discontent, they simply did not perceive themselves to be minorities. The institution of minority protection would go some way to rectifying this, "enlightening" communities hitherto ignorant of their "real" position in the international legal system and arming them with a host of rights which they would otherwise not have been able to access. Ethno-nationalism was not simply something to be honed and hedged in; it was also something to be cultivated and channelled.

Both tendencies - shielding legal minorities where they existed, creating them where they were thought to be needed - came to the fore most powerfully in the Near East. And two indigenous legal traditions played key facilitative roles here. The millet system, operational in various forms for centuries but crystallized in the nineteenth century, ${ }^{53}$ ensured that members of non-Muslim communities were afforded a measure of internal sovereignty as "nations", governing themselves mainly through communal laws derived from ecclesiastic tradition, in return for their ongoing loyalty to Istanbul. ${ }^{54}$ The system pluralized the Ottoman legal order to a significant degree, but it also contained important elements of hierarchy: during most of its existence, all Greek Orthodox Christians (Albanians, Bulgarians, Greeks, Romanians, Serbs, and others) were under the authority of the Greek patriarch, while many other Christians (Armenians, Copts, Chaldeans, Ethiopians, Georgians, and others) fell within the jurisdiction of the Armenian patriarch. ${ }^{55}$ The system was modified and augmented in the mid-nineteenth century, when reforms established mixed tribunals and supplemented existing mechanisms of

la Turquie, soit dans le règlement de ses difficultés sociales et politiques, soit dans l'accomplissement de ses devoirs humanitaires, il n'est aucun intérêt gouvernemental d'ordre intérieur au sujet duquel le Divan n'ait reçu de l'étranger des directions plus ou moins impératives." Le droit d'intervention et la Turquie: étude historique (Paris: A. Cotillon \& Cie, 1880) at 44.

${ }^{53}$ M. O. H. Ursinus, "Millet" in C. E. Bosworth et al., eds., The Encyclopaedia of Islam: New Edition, Vol. VII (Leiden: Brill, 1990) 61 at 63.

54 The standard reference for the system's development remains Benjamin Braude and Bernard Lewis, eds., Christians and Jews in the Ottoman Empire: The Functioning of a Plural Society, Two Vols. (New York: Holmes \& Meier, 1982).

55 See especially Kemal H. Karpat, "Ottoman Relations with the Balkan Nations after 1683" in Kemal H. Karpat, Studies on Ottoman Social and Political History: Selected Articles and Essays: Selected Articles and Essays (Leiden: Brill, 2002) 385 at 393; Fatma Müge Göçek, "The Decline of the Ottoman Empire and the Emergence of Greek, Armenian, Turkish, and Arab Nationalisms" in Fatma Müge Göçek, ed., Social Constructions of Nationalism in the Middle East (Albany: State University of New York Press, 2002) 15 at 18. 
intra-confessional administration with a general right of equality applicable to all Ottoman subjects. ${ }^{56}$

These reforms ran alongside enhanced reliance on a second set of legal arrangements the capitulations. Originally unilaterally revocable pledges (adhnames) by the sultan to ensure that non-Muslim foreigners could reside and do business in Ottoman territory, the capitulations had been introduced centuries earlier to streamline relations with the Empire's political allies and trading partners by granting a number of extraterritorial privileges to their nationals. ${ }^{57}$ In addition to privileges of a personal character, such as the freedom to practise a religion of one's choice and the freedom to travel freely throughout the Empire, most capitulations provided for a considerable number of economic (e.g. tax and customs exemptions) and juridical (e.g. consular courts wielding jurisdiction in cases involving disputes between foreigners) privileges. ${ }^{58}$ The provision of such privileges spurred the growth of powerful corporations like the Levant Company, armed with the licenses, connections, and commercial know-how requisite to occupy the commanding heights of Mediterranean trade. ${ }^{59}$ By the second and third quarters of the nineteenth century, they had largely been transformed into instruments of politico-economic subjugation, delegitimating the Porte's claim to what had come to be regarded as the most

\footnotetext{
${ }^{56}$ See generally Davison, Reform, supra note 23. For the mixed courts, see in particular Jasper Yeates Brinton, The Mixed Courts of Egypt (New Haven: Yale University Press, 1930).

${ }^{57}$ An arrangement between Süleyman I and François I historically dated to 1535 has long been regarded as the locus classicus of the regime by Turkish and non-Turkish scholars alike (typical examples are provided by Nihat Erim, Devlettlerarası Hukuk ve Siyasi Tarih Metinleri, Vol. I (Ankara: Türk Tarih Kurumu Basımevi, 1953) at 5-7; Philip Marshall Brown, "The Capitulations" 1 (1922-3) Foreign Affairs 71 at 77). For the text, one of the few to be couched in the form of a "treaty", see Traité de paix, d'amitié et de commerce [février 1535], reproduced in I. de Testa, Recueil des traités de la Porte ottomane avec les puissances étrangères depuis le premier traité conclu, en 1536, entre Suléyman I et François I, jusqu'à nos jours, Vol. I (Paris: Amyot, 1864) 15. Such assessments have come into question recently, as there is little evidence that the 1535 document was actually ratified by the sultan. See Joseph Matuz, "À propos de la validité des capitulations de 1536 entre l'Empire ottoman et la France" 24 (1992) Turcica 183; Halil Inalc1k, "Imtiyāzāt" in Bernard Lewis et al., eds., The Encyclopaedia of Islam: New Edition, Vol. III (Leiden: Brill, 1986) 1179 at 1183; Edhem Eldem, "Capitulations and Western Trade" in Suraiya N. Faroqhi, ed., The Cambridge History of Turkey, Vol. III (Cambridge: Cambridge University Press, 2006) 283 at 290; Daniel Goffman, "Negotiating with the Renaissance State: The Ottoman Empire and the New Diplomacy" in Virginia H. Aksan and Daniel Goffman, eds., The Early Modern Ottomans: Remapping the Empire (Cambridge: Cambridge University Press, 2007) 61 at 68-9. ${ }^{58}$ Nasim Sousa, The Capitulatory Régime of Turkey: Its History, Origin, and Nature (Baltimore: The Johns Hopkins Press, 1933) at 70-86; Maurits H. van den Boogert, The Capitulations and the Ottoman Legal System: Qadis, Consuls, and Beratlis in the $18^{\text {th }}$ Century (Leiden: Brill, 2005), ch. 1.

${ }^{59}$ For good histories, see Mortimer Epstein, The Early History of the Levant Company (London: Routledge, 1908); Alfred C. Wood, A History of the Levant Company (London: Oxford University Press, 1935). For a revealing case study, emblematic of the "system of overlapping circles of relatives, social and business acquaintances, collaborators and 'friends"' through which such corporations operated, see Despina Vlami, "Entrepreneurship and Relational Capital in a Levantine Context: Bartholomew Edward Abbott, the 'Father of the Levant Company' in Thessaloniki (Eighteenth-Nineteenth Centuries)" 6 (2009) Historical Review 129 at 156.
} 
rudimentary attributes of statehood - the capacity to exercise sovereign power over a delimited territory and population. ${ }^{60}$ The extraterritorial jurisdiction they afforded came to be abused not only by the European merchants whose activities they facilitated but also by the growing number of local "protégés" with whom these merchants collaborated and to whom letters patent (berats) were issued. ${ }^{61}$ So deeply entrenched had the capitulations become by the midnineteenth century that only through replacement of Ottoman with European legal institutions was it generally deemed possible to entertain their abrogation. For Friedrich Martens, extraterritoriality would "lose its significance and legal foundation" only "if existing conditions in the Orient change and governments of local states offer to foreigners sufficient guarantees concerning the inviolability of their persons and property". ${ }^{2}$ Similarly, a British minister observed when asked to abolish consular jurisdiction in Tunis after France had entered the country and introduced its own system of courts, "[t]he institutions which have grown up under the Capitulations with Turkey have been found essential for the protection of foreigners under the peculiar circumstances of the Ottoman Empire, and the necessity for them disappears when Tribunals organized and controlled by an European Government take the place of the Mussulman Courts". ${ }^{63}$

The balance-of-power treaties of the nineteenth century influenced both the millet system and the capitulations. On the one hand, entirely new minorities were created, as when independent Catholic and Protestant millets received formal recognition from Istanbul at the height of the Tanzimat. ${ }^{64}$ No such millets had previously existed in law; Catholics, for instance,

60 " [T] he sovereign which represents the state in its international relations must be able ... to extend his or its power equally throughout the whole of his or its domains. When this cannot be done, the state and its sovereign either fall out of the pale of the international law, or are admitted by other states and sovereigns upon sufferance. ... The present condition and treatment of the Ottoman Empire afford a striking illustration of this practice.” John Norton Pomeroy, Lectures on International Law in Time of Peace, ed. Theodore Salisbury Woolsey (Boston: Houghton, Mifflin and Co., 1886) at 51.

61 Attempts were made by Ottoman authorities as early as the eighteenth century to clamp down on the proliferation of berats, in some cases by issuing new berats to ostensibly "loyal" non-Muslim merchants. Such efforts generally yielded no more than short-term results. See van den Boogert, supra note 58, at 105-12; Ali İhsan Bağ1ş, Osmanlı Ticaretinde Gayrî Müslimler: Kapitülasyonlar - Avrupa Tüccarlar - Beratl Tüccarlar - Hayriye Tüccarlar (1750-1839) (Ankara: Turhan Kitabevi, 1983), esp. ch. 2; Bruce Masters, “The Sultan’s Entrepreneurs: The Avrupa Tüccaris and the Hayriye Tüccaris in Syria” 24 (1992) International Journal of Middle East Studies 579.

${ }^{62}$ Friedrich Martens, Das Consularwesen und die Consularjurisdiction im Orient, tr. H. Skerst (Berlin: Weidmannsche Buchhandlung, 1874) at 320 (translation mine).

${ }^{63}$ Quoted in Mark Frank Lindley, The Acquisition and Government of Backward Territory in International Law, Being a Treatise on the Law and Practice relating to Colonial Expansion (London: Longmans, 1926) at 313.

${ }^{64}$ Vartan H. Artinian, "The Formation of Catholic and Protestant Millets in the Ottoman Empire" 28 (1975) Armenian Review 3, esp. at 8, 11. 
had found refuge on Ottoman soil for centuries (as had, more famously, Sephardic Jews), but had simply been subsumed beneath the jurisdiction of the Greek and Armenian patriarchs. While such enlargements and refinements of the millet system were driven in part by the Ottomans' own commitment to keep pace with developments in the West, they were also fed by external pressure, such as American and British intervention on behalf of missionaries operating in the Near East. ${ }^{65}$ On the other hand, existing minorities would often be armed with more sophisticated resources of material and symbolic mobilization. The already mentioned transformation of the Peloponnese into an independent Christian kingdom is a classic example of this phenomenon, leveraging an already powerful millet (or, more precisely, a part thereof) into a position of de jure statehood in a few short years. Considerable factionalism surrounded the question of independence within the Greek Orthodox millet itself: members of its Istanbul elite resisted calls for a pan-Hellenic alliance, ${ }^{66}$ while bandits and irregular militia in mainland Greece often fought against state-centralization initiatives once political independence had been achieved. ${ }^{67}$ But the outcome was still far-reaching: assisted by European powers, members of a millet had bootstrapped themselves into statehood virtually overnight. Efforts to create viable states for other Balkan nations in the final decades of the century, culminating in the Treaty of Berlin, would radicalize inter-ethnic relations throughout the Near East. Amid the waves of internecine violence and counter-insurgent police action, the Empire's Muslims (and, increasingly, Turkish-Muslims) themselves grew fonder of the notion that they comprised an independent millet. ${ }^{68}$ Once again, ethno-nationalism was not merely a force to be fettered, but also one to be fostered.

The fact that differences of faith figured as explicitly as they did in the Ottoman treaties points to the importance of the tension between the "public law of Europe" and the Ottoman juridico-political order. In regulating majority-minority dynamics on Europe's semi-periphery,

65 See, e.g., Joseph L. Grabill, Diplomacy and the Near East: Missionary Influence on American Policy, 1810-1927 (Minneapolis: University of Minnesota Press, 1971) at 14-5; Paul William Harris, Notbing but Christ: Rufus Anderson and the Ideology of Protestant Foreign Missions (New York: Oxford University Press, 1999) at 104-5. See further Chapter IV.

66 That an independent Greece would likely seek greater ecclesiastic autonomy - and thus attenuate the authority of the Ecumenical Patriarch in Istanbul - had a hand in this. G. Georgiades Arnakis, "The Greek Church of Constantinople and the Ottoman Empire" 24 (1952) Journal of Modern History 235 at 248.

67 Achilles Batalas, "Send a Thief to Catch a Thief: State-Building and the Employment of Irregular Military Formations in Mid-Nineteenth-Century Greece" in Diane E. Davis and Anthony W. Pereira, eds., Irregular Armed Forces and Their Role in Politics and State Formation (Cambridge: Cambridge University Press, 2003) 149, esp. at 154.

68 Bruce Masters, Christians and Jews in the Ottoman Arab World: The Roots of Sectarianism (Cambridge: Cambridge University Press, 2001) at 134. 
European powers showcased their capacity to exercise control over large tracts of territory and also cultivated a tighter, more streamlined vision of what it meant to be "European". One day, it was assumed, the "Sick Man of Europe" would pass away. ${ }^{69}$ And when this transpired, the Empire's last non-Muslim communities would go their own way, breaking from the fold to form their own states. Until that day came, though, it was in the interests of the Concert - and of the international legal order it safeguarded - to maintain as much stability as possible. What is more, if the Ottoman state was constantly teetering on the brink of dissolution, embodying the heterogeneous polity par excellence, ${ }^{70}$ then part of what it meant to be European lay precisely in not being heterogeneous. ${ }^{71}$ Where state-centralization efforts had already precipitated strong national identities, as in Britain and France, the "problem" had in some sense been "solved": England's relation to Wales and Scotland was rarely, if ever, structured as one between a majority and two minorities; and while enemies of Paris might point to a Brittany or Alsace, France itself would not recognize their inhabitants as minorities in law. ${ }^{72}$ However, where such centralization had not been achieved, as in the House of Osman's dominions, the task of the great powers - their civilizing mission - was to ensure that non-Muslim communities enjoyed protection as minorities. Reorganizing the Near East did not, therefore, permit the Concert simply to flex its interventionist muscles, converting an empire whose minorities were often dispersed and without national consciousness into a playground for nation-building. It also rendered minority protection a mechanism whose sphere of application was spatially and temporally elsewhere, in regions that had "not yet" achieved the "level" of legal and

\footnotetext{
69 There was often a crypto-theological tinge to this line of thought. As late as the mid-nineteenth century, for instance, one finds the projected disintegration of the Ottoman polity being linked to scriptural prophesies of "restoration" in the Holy Land. See, e.g., G. S. Faber, The Predicted Downfall of the Turkish Power, the Preparation for the Return of the Ten Tribes (London: Thomas Bosworth, 1853).

${ }^{70}$ See, e.g., Thomas Thornton, The Present State of Turkey; or A Description of the Political, Civil, and Religious, Constitution, Government, and Laws of the Ottoman Empire ..., $2^{\text {nd }}$ Ed (London: Joseph Mawman, 1809) at 59-60 ff.

71 As early as 1795, ambitious treatise writers could assert that "if we compare the conduct of CHRISTIAN nations, with that of nations profeffing any other religion, (whatever may be their ftages of improvement, or in whatever æra of their glory,) the refult I believe will be uniform and univerfal, that the one will be eminent over the other for regularity, equity, and benevolence". Robert Ward, An Enquiry into the Foundation and History of the Law of Nations in Europe, from the Time of the Greeks and Romans, to the Age of Grotius, Vol. II (London: A. Strahan and W. Woodfall, 1795) at 1-2. Such sentiments only gained currency over time: "The cruelties in Servia, in 1815, the awful massacre at Scio, and the atrocities committed on the Christians in almost every city of the Turkish empire at the time of the Greek revolution, prove that the old Turkish mode of treating Christians is not forgotten ...." C. M. Kennedy, The Influence of Christianity upon International Law (Cambridge: Macmillan, 1856) at 115.

${ }^{72}$ See, e.g., Oscar I. Janowsky, Nationalities and National Minorities (With Special Reference to East-Central Europe) (New York: Macmillan, 1945) at 18.
} 
administrative concentration perfected by a France. ${ }^{73}$ Even before Berlin, the influential Gustave Rolin-Jaequemyns felt comfortable writing that the Concert had a mission "agir dans un intérêt d'humanité, et plus particulièrement, dans ce siècle", to represent "l'ensemble de l'Europe" in its relations with "les peuples orientaux". 74

In sum, it was in the nineteenth century that much of what is now recognized as the international law of minority protection was developed. The Concert of Europe fashioned, apportioned, and dissolved states, devoting the brunt of its energy to the Near East. In the words of Holland, it "remade the map of Europe in 1815, liberated Greece in 1827, constituted Belgium in 1839, regulated the Ottoman Empire in 1856, freed the Balkan States in 1878, and later meddled with the navigation of the Danube and the Suez Canal, the boundaries of Greece, and the fate of Crete". ${ }^{75}$ In some cases this was done to protect communities previously recognized as minorities. In others the wholesale fabrication of minorities was deemed necessary. Both types of endeavour were grounded in a felt need to engage ethno-nationalism containing it where it might threaten and cultivating it where it might buttress the European state system. And both played key roles in furthering the Eurocentric international system the Concert safeguarded. Minority protection was essential to the Concert's capacity to deploy force in the name of inter-state equilibrium. It was also integral to its self-constitution as a tightly integrated Europe, confident in the normative supremacy of its models of statehood and disposed to see minority protection as a governmental instrument applicable principally in the East.

\section{Managing Minorities in a New World Order}

Historians of international law have long characterized 1919 as a watershed, transforming the discipline - its theory, doctrine, and practice - from top to bottom. International law had proven no more able to control industrial and military rivalry between Manchester and the Rhineland than to manage majority-minority relations in the few multinational empires that

\footnotetext{
73 A view of France shared widely for some time to come; see, e.g., Théodore Ruyssen, Les minorités nationales d'Europe et la Guerre mondiale (Paris: Les presses universitaires de France, 1923) at 82.

${ }^{74}$ Gustave Rolin-Jaequemyns, "Le droit international et la phase actuelle de la question d'Orient" 8 (1876) RDILC 293 at 368 (partly de-emphasized from original).

75 Thomas Erskine Holland, Lectures on International Law, ed. T. A. Walker and W. L. Walker (London: Sweet \& Maxwell Ltd., 1933) at 105.
} 
remained. Inter-state competition, reaching toxic levels in the final decade of the nineteenth century, fuelled struggles for territory and resources throughout Africa, Asia, and the Americas. All of this rendered classic international law a thing of the past, a resource to be mined here and there, perhaps, but hardly the lynchpin of international relations it had previously been. "Sovereignty", however understood, was now to be disaggregated and disciplined in the name of a new world order.

Such assessments are often exaggerated, resting on an excessively static understanding of nineteenth- and early twentieth-century international law and overplaying post-Versailles international law's claims to novelty. ${ }^{76}$ The latter half of the long nineteenth century had seen greater professional organization and increased codification of positive law. The Institut de droit international and International Law Association were up and running by the time its final decades rolled around, treatise writers worked hard to cobble together a "scientific" canon capable of withstanding Austinian charges of imprecision and ineffectiveness, the first professional journals of international law entered into circulation, the 1899 and 1907 Hague Conferences developed a legal framework that sought to cast a regulatory net over the conduct of warfare, and new treaties were rolled together with bits and pieces of state practice and opinio juris to generate a barrage of international wrongs, such as the blanket prohibitions of slavery that surfaced toward the fin de siècle. ${ }^{77}$ In 1912, one commentator would observe that "[t]he half century beginning with the Declaration of Paris in 1856 and ending with the London Conference in 1909 has seen greater progress in the direction of internationalism and more successful attempts to improve and codify international law than any other in history, or perhaps more than all previous half-centuries combined". ${ }^{78}$ The League of Nations itself could be characterized as a reformatory rather than revolutionary project. Far from supplanting the Concert of Europe, it sublimated characteristically nineteenth-century obsessions with alliance networks and multilateral diplomacy into an aspirationally, if not always actually, global system of

\footnotetext{
${ }^{76}$ For an attempt to demonstrate that the assault on 'sovereignty' encountered so often in post-1919 scholarship was driven partly by ignorance or misreading of nineteenth-century treatises, see Anthony Carty, "19 th Century Textbooks and International Law", Ph.D. dissertation, University of Cambridge (1972) at i-xxiii.

${ }^{77}$ For the strongest available account of the period, see Martti Koskenniemi, The Gentle Civilizer of Nations: The Rise and Fall of International Law 1870-1960 (Cambridge: Cambridge University Press, 2001), esp. ch. 1. See further Martti Koskenniemi, "The Legacy of the Nineteenth Century" in David Armstrong, ed., Routledge Handbook of International Law (London: Routledge, 2009) 141.

78 Amos S. Hershey, "History of International Law since the Peace of Westphalia" 6 (1912) AJIL 30 at 50.
} 
interdependence. ${ }^{79}$ Pace Schmitt, who bemoaned the dissolution of the jus publicum Europaeum and denounced the League as facilitative of a larger "leap into the nothingness of a universality lacking any grounding in space or on land", ${ }^{80}$ the Concert system was not replaced so much as expanded and augmented. ${ }^{81}$

Yet the customary periodization - that the system inaugurated in 1919 departed from the international law produced by the European Concert - is not without merit. Something new had indeed emerged. The great powers' membership had been altered, with Austria, Russia, and Prussia/Germany falling from grace, and Japan and the United States rising to take their place. Justifiably or not, international lawyers of the period routinely cast their predecessors as diehard voluntarists whose commitment to state sovereignty rendered international order all but impossible. ${ }^{82}$ And there was a decidedly institutionalist bent to the international law developed after the war: whereas the old law of nations had not contained many "rules for its own modification", one jurist later reflected, the new international law aimed "to eliminate war as an institution", and was therefore "under a necessity to develop dynamic rules" to limit the threat of conflict. ${ }^{83}$ Nowhere was this felt with greater force than in regards to minority protection.

79 The League, Inis Claude wrote, "was intended to introduce radical changes in the operation of the multistate system, rather than to accomplish or even to presage the replacement of that system". Inis L. Claude Jr., Swords into Plowshares: The Problems and Progress of International Organization, $3^{\text {rd }}$ Rev. Ed. (New York: Random House, 1964$)$ at 50.

${ }^{80}$ Carl Schmitt, The Nomos of the Earth in the International Law of the Jus Publicum Europaeum, tr. G. L. Ulmen (New York: Telos, 2003 [1950]) at 237.

${ }^{81}$ It is telling that even so prominent an advocate of the League as Hudson felt compelled to distinguish sharply between the League Council, in which "the hegemony of the Great Powers was recognized", and the Assembly, in which "the principle of the equality of states found its full expression". Manley O. Hudson, Progress in International Organization (Stanford: Stanford University Press, 1932) at 34. Such sentiments were anything but uncommon; see, e.g., Philip Marshall Brown, International Society: Its Nature and Interests (New York: Macmillan, 1923) at 126-7 ("The 'Primacy of the Great Powers' thus finds its full recognition and the equality of nations its full repudiation in the organization and control of the Council."). By way of illustration, consider also Arts. 11 and 19 of the League Covenant - the former stipulating that "war or threat of war" is "a matter of concern to the whole League", the latter authorizing the League Assembly to "advise the reconsideration" of "treaties which have become inapplicable". Both are arguably best read as indicators of the League's commitment to a general "community interest" derived from the Concert system. Stephen C. Neff, "Conflict Termination and Peace-Making in the Law of Nations: A Historical Perspective" in Carsten Stahn and Jann K. Kleffner, eds., Jus Post Bellum: Towards a Law of Transition from Conflict to Peace (The Hague: T. M. C. Asser Press, 2008) 77 at 85-6. For the provisions themselves, see Covenant of the League of Nations Adopted by the Peace Conference at Plenary Session, April 28, 1919,13 (1919) AJIL Sup. 128 at 132, 136.

82 Cf. P. H. Kooijmans, The Doctrine of the Legal Equality of States: An Inquiry into the Foundations of International Law (Leyden: A. W. Sythoff, 1964) at 191-2 ff.

83 Josef L. Kunz, "The Law of Nations, Static and Dynamic" 27 (1933) AJIL 630 at 630. For a taxonomy of the various tropes of reconstruction to which this and similar sentiments gave rise, see Thomas Skouteris, The Notion of Progress in International Law Discourse (The Hague: T. M. C. Asser, 2010) at 103-20. 
Since tensions between majority and minority communities had been integral to the Great War's eruption, minority protection was placed at the forefront of reconstruction efforts after the war.

International guarantees of minority protection were designed to apply to the war's victors only marginally. And much of their normative architecture was developed in relation to the Near East. Writing for the Permanent Court in the influential Greco-Bulgarian "Communities" case, Anzilotti, for instance, linked his definition of the crucial term "community" 84 to the Near East: "the material benefits which from time immemorial in the East individuals of the same race, religion, language and traditions, have derived from uniting into communities, are well known", he wrote, adding that the instrument in question in that case - a 1919 convention regulating a population exchange between Greece and Bulgaria - regarded "the conception of a 'community' from the point of view of [the] exclusively minority character which it has had for centuries past in the East". ${ }^{85}$ Indeed, if minority protection came in certain circumstances to be seen as a necessary precondition for recognition, such that a state's admission to "membership of the community of states was conditional on not ill treating minorities", 86 this was so only inasmuch as the state to which recognition was to be extended was always already assumed to deviate from dominant Western paradigms of national statehood. Centuries of state-formation in the West, often involving massive forced migration, had generated societies with cohesive identities and institutions. Where nationhood had not (yet) been consolidated, minority protection was to provide the palliative. As if it were not enough, then, that "the initiative for protecting minorities came, not from the minorities themselves, but from outside", ${ }^{87}$ such protection was typically limited to regions in which new states had been established or existing states reconstituted by the great powers.

The techniques of protection available after the war can be grouped into four classes: custom-tailored minority treaties, the most typical solution in central and eastern Europe (Czechoslovakia, Greece, Poland, Romania, and the Serb-Croat-Slovene state); specific bilateral

\footnotetext{
84 “'A] group of persons living in a given country or locality, having a race, religion, language and traditions of their own and united by this identity of race, religion, language and traditions in a sentiment of solidarity, with a view to preserving their traditions, maintaining their form of worship, ensuring the instruction and upbringing of their children in accordance with the spirit and traditions of their race and rendering mutual assistance to each other". The Greco-Bulgarian "Communities", Advisory Opinion, PCIJ Rep. Series B No. 17 (1930) at 21.

85 Ibid., at 20, 21-2.

86 A. W. Brian Simpson, Human Rights and the End of Empire: Britain and the Genesis of the European Convention (Oxford: Oxford University Press, 2004) at 113.

${ }^{87}$ Jacob Robinson et al., Were the Minorities Treaties a Failure? (New York: Institute of Jewish Affairs, 1943 ) at 6.
} 
or multilateral agreements enshrining minority protection (Danzig, Memel, and Upper Silesia); chapters concerning minority protection inserted into general peace treaties (Austria, Bulgaria, Hungary, and Turkey); and declarations required of certain states (Albania, Estonia, Finland, Latvia, and Lithuania) upon admission to the League. ${ }^{8}$ One or another form of minority protection was thus to be implanted in a string of states running from the Baltic to the Mediterranean, the so-called "minorities belt", with the instrument in question being selected and attuned in situ. (The "belt" would later be extended to Iraq, which was compelled to issue a largely disregarded declaration of commitment to minority protection as a condition of its emancipation from mandatory rule and admission to the League. ${ }^{89}$ ) Outlined by the Permanent Court in an oft-quoted passage from its 1935 advisory opinion in Minority Schools in Albania, the system had two basic objectives. On the one hand, it aimed to "secure for certain elements incorporated in a State, the population of which differs from them in race, language or religion, the possibility of living peaceably alongside that population and co-operating amicably with it". On the other hand, it sought to preserve "the characteristics which distinguish them from the majority" with a view to "satisfying the ensuing special needs". ${ }^{0}$

The most ambitious mechanism was the minority treaty. The first such treaty - the socalled "Little Treaty of Versailles" - was concluded with Poland in 1919. ${ }^{91}$ Partitioned time and again over the course of the nineteenth century through war and diplomatic Diktat, beleaguered,

\footnotetext{
${ }^{88}$ For succinct tabulations, see Athanasia Spiliopoulou Åkermark, Justifications of Minority Protection in International Law (The Hague: Kluwer, 1997) at 105-6; Natan Lerner, "The Evolution of Minority Rights in International Law" in Catherine Brölman, René Lefeber, and Marjoleine Zieck, eds., Peoples and Minorities in International Law (Dordrecht: Nijhoff, 1993) 77 at 83; Anna Meijknecht, Towards International Personality: The Position of Minorities and Indigenous Peoples in International Law (Antwerp: Intersentia, 2001) at 123.

89 The issue of minority protection entered Iraq in full force only in 1930, and the Permanent Mandates Commission, the League organ authorized to supervise mandatory rule, was anything but convinced that Britain's formal withdrawal would bode well for the country's Kurds and Assyrians. Susan Pedersen, “Getting Out of Iraq in 1932: The League of Nations and the Road to Normative Statehood" 115 (2010) American Historical Review 975 at 992-8; and also Nelida Fuccaro, "Minorities and Ethnic Mobilisation: The Kurds in Northern Iraq and Syria" in Nadine Méouchy and Peter Sluglett, eds., The British and French Mandates in Comparative Perspectives (Leiden: Brill, 2004) 579 at 586.

${ }^{90}$ Minority Schools in Albania, Advisory Opinion, PCIJ Rep. Series A/B No. 64 (1935) at 17. As the Court explained, this approach itself demanded a twofold strategy: "The first is to ensure that nationals belonging to racial, religious or linguistic minorities shall be placed in every respect on a footing of perfect equality with the other nationals of the State. The second is to ensure for the minority elements suitable means for the preservation of their racial peculiarities, their traditions and their national characteristics. These two requirements are indeed closely interlocked, for there would be no true equality between a majority and a minority if the latter were deprived of its own institutions, and were consequently compelled to renounce that which constitutes the very essence of its being as a minority." Ibid.

91 Treaty of Peace between the United States of America, the British Empire, France, Italy, and Japan, and Poland, signed at Versailles, June 28, 1919, 225 CTS 412.
} 
territorially fractured Poland had long served as a fulcrum for intra-European rivalry. For Mazzini, it had been "a nation thrown into the grave alive". "For Marx and Engels, it was nothing less than "the cement which holds together the three great military despots: Russia, Prussia and Austria". ${ }^{93}$ With Europe's imperial houses now in disarray, it was to be reconstituted, armed with a new batch of legal and political institutions, and reinserted into an international legal order that had itself been overhauled. Article 1 set the tone, ensuring that the provisions which followed would be "recognised as fundamental laws, and that no law, regulation or official action shall conflict or interfere with these stipulations". Article 2 explained that Poland undertook to "assure full and complete protection of life and liberty to all inhabitants of Poland without distinction of birth, nationality, language, race or religion". And Article 7 provided similarly across-the-board guarantees of equality, stating that "[a]ll Polish nationals shall be equal before the law and shall enjoy the same civil and political rights without distinction as to race, language or religion". The term "nationals" was defined broadly in Articles 3 through 6, including, inter alia, Austrian, German, Hungarian, and Russian citizens resident habitually in Poland at the time of the treaty's entry into force or born on Polish soil to parents resident habitually in the country at this time. Rights pertaining to the use of language, the practice of religion, and the establishment and maintenance of educational and other institutions were enshrined in Articles 2, 7, 8, and 9. Provisions were inserted to provide the Jewish minority with rights in connection with the allocation of public funds for education, as well as a guarantee that its members would not be required to work on the Sabbath (Articles 10 and 11 respectively). Article 12 made it clear that these stipulations constituted "obligations of international concern" and would be "placed under the guarantee of the League of Nations", disputes arising from a "difference of opinion as to questions of law or fact" being referable to the World Court. ${ }^{94}$

No less telling is the letter Georges Clemenceau, France's prime minister and president of the Paris Peace Conference, sent to Warsaw along with the treaty. ${ }^{95}$ Clemenceau explained

\footnotetext{
92 Giuseppe Mazzini, “The European Question: Foreign Intervention and National Self-Determination” [1847] in Recchia and Urbinati, supra note 40, at 193, 194.

${ }^{33}$ Karl Marx and Friedrich Engels, "For Poland" [1875], tr. Paul Jackson, in The First International and After: Political Writings, Vol. III (London: Penguin / New Left Review, 1974) 388 at 391.

${ }^{94}$ For these provisions, see Polish Minority Treaty, supra note 91, at 416-9.

95 "Letter addressed to M. Paderewski by the President of the Conference transmitting to him the Treaty to be signed by Poland under Article 93 of the Treaty of Peace with Germany", reproduced in Harold W. V. Temperley, ed., A History of the Peace Conference of Paris, Vol. V (London: Oxford University Press, 1921) 432.
} 
that international law had long shielded minorities from persecution, albeit usually with somewhat different mechanisms: instead of being enmeshed in a network of institutions controlled from Geneva, as it now was, minority protection had been nested in balance-ofpower regimes coordinated by the Concert. That it was now the League, and not some great power, that would be responsible for monitoring compliance with the Polish treaty should, he argued, assuage Warsaw's fears of illegitimate intervention.

"Under the older system the guarantee for the execution of similar provisions was vested in the Great Powers. Experience has shown that this was in practice ineffective, and it was also open to the criticism that it might give to the Great Powers, either individually or in combination, a right to interfere in the internal constitution of the states affected which could be used for political purposes. Under the new system the guarantee is entrusted to the League of Nations. The clauses dealing with this guarantee have been carefully drafted so as to make it clear that Poland will not be in any way under the tutelage of those Powers who are signatories to the treaty." 96

This was a position that would find a home in many studies of international law before long. Claiming that the minority treaties were designed to counter long-standing accusations that the great powers armed themselves with rights of interference in the domestic affairs of weaker states became routine. ${ }^{97}$

Another passage from Clemenceau's letter illustrates well the power dynamics at work beneath the Polish treaty. Underscoring the point that Poland's reconstitution had been achieved by the great powers, he left no room for doubt as to who held the reigns:

"I must also recall to your consideration the fact that it is to the endeavours and sacrifices of the Powers in whose name I am addressing you that the Polish nation owes the recovery of its independence. It is by their decision that Polish sovereignty is being re-established over the territories in question and that the inhabitants of these territories are being incorporated in the Polish nation. It is on the support which the resources of the Powers will afford to the League of Nations that, for the future, Poland will to a large extent depend for the secure possession of these territories. There rests, therefore, upon these Powers an obligation, which they cannot evade, to secure in the most permanent and solemn form guarantees for certain essential rights which will afford to

\footnotetext{
96 Ibid., at 434.

${ }^{97}$ See, e.g., Helmer Rosting, "Protection of Minorities by the League of Nations" 17 (1923) AJIL 641 at 647; P. E. Corbett, "What is the League of Nations?" 5 (1924) BYIL 119 at 145.
} 
the inhabitants the necessary protection whatever changes may take place in the internal constitution of the Polish State." 98

The great powers were determined to maintain control over a minority protection regime of which they were the principal authors. And they were also committed to making this determination known, in Warsaw and elsewhere. Poland's reintegration as an independent sovereign state equipped to resist a resurgent Germany or a revolutionary Russia had occurred during a curious juncture in international history. And it involved a state of affairs that could be sustained, if at all, by the ongoing involvement of the great powers. The force of Clemenceau's words can hardly be overemphasized: it was on the "decision" of these powers that Poland's independence had been restored, and it was on this "decision" that its economy and society would depend for the foreseeable future. ${ }^{99}$

The typology exemplified by the Polish treaty - a highly conditional form of sovereignty designed largely by exogenous actors and installed by a combination of suasion and force - was transplanted into each of the following treaties, from Czechoslovakia, with which the immediately following treaty was concluded, to the Serb-Croat-Slovene state, Romania, and so on down the line in a cascading series until finally an agreement was concluded with Danzig. One cannot, of course, plot a straight course from Poland in 1919 to Turkey in 1923. The Lausanne Peace Treaty was drafted under significantly different circumstances and afforded fewer opportunities for intervention than the Polish Minority Treaty, its minority protectionrelated provisions being relatively diluted. But the structural similarities between the various post-war instruments, the Lausanne Peace Treaty included, are undeniable. ${ }^{100}$ It was estimated in 1925 that the post-First World War settlement had been responsible for roughly eighty million people changing nationalities, and that something in the vicinity of twenty of these

98 "Letter addressed to M. Paderewski", supra note 95, at 434.

${ }^{99}$ Cf. Carole Fink, "The Minorities Question at the Paris Peace Conference: The Polish Minority Treaty, June 28, 1919” in Manfred F. Boemeke, Gerald D. Feldman, and Elisabeth Glaser, eds., The Treaty of Versailles: A Reassessment After 75 Years (Cambridge and Washington: Cambridge University Press / German Historical Institute, 1998) 249 at 273 (analyzing Poland as "a fragile republic encumbered by extraordinary internationally imposed controls on its domestic legislation and administration").

100 For a cross-section, see Protection of Linguistic, Racial and Religious Minorities by the League of Nations: Provisions Contained in the Various International Instruments at Present in Force, C. L. 110. 1927. I. (Geneva: League of Nations, 1927). For glosses, see, e.g., Akermark, supra note 88, at 106-8; Francesco Capotorti, Study on the Rights of Persons Belonging to Ethnic, Religious and Linguistic Minorities, UN Doc. E/CN.4/Sub.2/384 (1991) at 18, 1626 generally. 
eighty had come to be members of legal minorities. ${ }^{101}$ It was within the legal frameworks typified by the Polish Minority Treaty and set out, with requisite adaptations, in later minority and peace treaties, the Lausanne Peace Treaty included, that much of this transformation was achieved.

A new group of institutional apparatuses was to ensure the functioning of this system. Predicated on the idea that minorities should be able to access the League Council when their treaty rights had been violated and domestic avenues of redress exhausted, a "Minorities Section" was established within the League Secretariat to filter complaints sent to Geneva. For a petition to be deemed receivable and transmitted to a further "Minorities Committee", convened by and comprised of Council members, it needed to be vetted for formal and substantive "receivability" by the Minorities Section. ${ }^{102}$ In 1923 the Council laid out five conditions that petitions - generally submitted by individuals and not groups ${ }^{103}$ - would have to satisfy in order to complete this vetting procedure. The petition had to "have in view the protection of minorities in accordance with the Treaties"; could not have been "submitted in the form of a request for a severance of political relations between the minority in question and the State of which it forms a part"; must not have derived "from an anonymous or unauthenticated source"; must not have contained "violent language"; and needed to "contain information or refer to facts which have not recently been the subject of a petition submitted to the ordinary procedure". ${ }^{104}$ The fourth criterion - the least precise - was the most determinative: its vagueness bolstered the vetting officials' already considerable discretionary authority, and seems to have permitted various cultural biases to be smuggled into their decision-making. ${ }^{105}$ Unsurprisingly, navigating the petitions system - involving a large number

\footnotetext{
101 William E. Rappard, International Relations as Viewed from Geneva (New Haven: Yale University Press, 1925$)$ at 44. For an even larger estimate, see Macartney, supra note 8, at 211.

${ }^{102}$ For the procedure, see H. B. Calderwood, The Protection of Minorities by the League of Nations (Geneva: Geneva Research Information Committee, 1931) at 7-9; Julius Stone, International Guarantees of Minority Rights: Procedure of the Council of the League of Nations in Theory and Practice (London: Oxford University Press, 1932) at 35-6, chs. 3-5 generally.

${ }^{103}$ Cf. Louis B. Sohn, "The Rights of Minorities" in Louis Henkin, ed., The International Bill of Rights: The Covenant on Civil and Political Rights (New York: Columbia University Press, 1981) 270 at $274 \mathrm{ff.}$

104 "Resolution Adopted by the Council on September 5 ${ }^{\text {th }}$, 1923", reproduced in Protection of Linguistic, Racial or Religious Minorities by the League of Nations: Resolutions and Extracts from their Minutes of the Council, Resolutions and Reports adopted by the Assembly, relating to the Procedure to be followed in Questions concerning the Protection of Minorities, C. 24. M. 18. 1919. I. (Geneva: League of Nations, 1929) 7.

105 See Jane K. Cowan, "Who's Afraid of Violent Language? Honour, Sovereignty and Claims-Making in the League of Nations" 3 (2003) Anthropological Theory 271.
} 
of procedural rules ${ }^{106}$ - proved challenging. ${ }^{107}$ Turkey would be subject to petitions, often from Armenian citizens understandably troubled by their extremely precarious status. ${ }^{108}$ But the main sources were central and east European in origin - chiefly from ethnic Germans in Poland and Hungarians in Czechoslovakia and Romania, until recently at the helm of powerful empires and clearly dissatisfied with the post-war settlement, but also from Jews in Romania, Albanians in Greece, and others.

Crucial to the implementation of both the minority treaties and the petitions system which buttressed it was the delimitation of the space in which minority protection was to apply. The League Covenant contained no provision necessitating universal observance of minority rights among League members. Wilson's second draft had included an article providing something broadly along these lines, requiring "all new States to bind themselves as a condition precedent to their recognition as independent or autonomous States, to accord to all racial or national minorities within their several jurisdictions exactly the same treatment and security, both in law and in fact, that is accorded the racial or national majority of their people" ${ }^{109}$ But this and similar proposals, such as repeated insistence on the part of the Japanese delegation that a clause recognizing the principle of racial equality be included, ${ }^{110}$ had proven unworkable. ${ }^{111}$

\footnotetext{
${ }^{106}$ For a semi-official discussion from a member of the Minorities Section, see Pablo de Azcárate, League of Nations and National Minorities: An Experiment (Washington: Carnegie Endowment for International Peace, 1945) at 102-8. For a more recent outline, see Jennifer Jackson Preece, National Minorities and the European Nation-States System (Oxford: Clarendon Press, 1998) at 80-3.

${ }^{107}$ For an especially challenging context, see Julius Stone, Regional Guarantees of Minority Rights: A Study of Minorities Procedure in Upper Silesia (New York: Macmillan, 1933).

108 Gustave Köver, Histoire d'une trahison: le calvaire des minorités nationales et la Société des Nations (Genève: Editions du Bureau central des minorités, 1939) at 35-40. Other petitions were submitted by Greek communities in Istanbul and on the Black Sea coast, and by the Christians of Mosul: Gustave Köver, L'erreur initiale de la Société des Nations: Documents pour server à l'histoire de la question minoritaire (Genève: Édition du Bureau central des minorités, 1940) at 4566.

109 “Wilson's Second Draft or First Paris Draft, January 10, 1919, with Comments and Suggestions by D. H. M.”, reproduced in David Hunter Miller, The Drafting of the Covenant, Vol. II (New York and London: G. P. Putnam's Sons, 1928) 65 at 91.

110 See Paul Gordon Lauren, "Human Rights in History: Diplomacy and Racial Equality at the Paris Peace Conference" 2 (1978) Diplomatic History 257.

111 David Hunter Miller, advisor to the American delegation at the Paris Peace Conference, found Wilson's proposal both too weak, in that it was to apply only to new states, and too strong, given that universalizing entitlements like the freedom of language was in his eyes logistically impossible. See the commentary in "Wilson's Second Draft", supra note 109, at 91; and also David Hunter Miller, The Drafting of the Covenant, Vol. I (New York and London: G. P. Putnam's Sons, 1928) at 47. For further discussion, see Malcolm D. Evans, Religious Liberty and International Law in Europe (Cambridge: Cambridge University Press, 1997) at 88.
} 
The entire system would eventually break down, in no small part due to charges of double standards stemming from such partial application. In September 1934, Józef Beck of Poland proposed that the League's minority protection obligations be extended to all League members, and indexed continued Polish cooperation to such universalization. Commanding "l'approbation spontanée" of the entire "nation polonaise", as one Warsaw-based commentator put it, ${ }^{112}$ this proposal received support from other delegates - including Tevfik Rüştü Bey, the Turkish delegate - the following day. ${ }^{113}$ Snowballing into a more general movement, it led to the delegitimation of the entire system. Germany, long a critic of Anglo-French advocacy of minority rights ${ }^{114}$ and now a staunch supporter of its ethnic kin in Poland and elsewhere before the Permanent Court, ${ }^{115}$ had already pulled out of the League in November $1933 .{ }^{116}$ Poland's decision to condition further cooperation on the universalization of minority protection, combined with the support it received from other League members, brought this process to a head. The last nails in the coffin might well have come from the usual suspects: the establishment of bilateral regimes escaping League control, ${ }^{117}$ the inelasticity of available dispute resolution procedures, ${ }^{118}$ and, not least, Geneva's abysmal track record in constraining the use of force, exemplified by Italy's invasion of Abyssinia and the devastating Spanish Civil War. But it is telling that it was disputes about the scope of minority protection that led to the League's ultimate deracination. ${ }^{119}$

\footnotetext{
112 Stanislaw J. Paprocki, La Pologne et le problème des minorities. Recueil d'informations (Varsovie: Institut pour l'étude des questions minoritaires, 1935) at 10.

113 Robinson, supra note 87 , at 179.

114 As early as 1917, Austrian and German authorities had denounced as hypocritical claims that the Allied war effort was driven by a dedication to self-determination (pointing as evidence to Ireland, Finland, the Boer Republics, and north African territories under British, French, and Italian colonial rule). Antonio Cassese, SelfDetermination of Peoples: A Legal Reappraisal (Cambridge: Cambridge University Press, 1995) at 24.

115 Germany would take a number of such grievances to the Court - relating to Warsaw's eviction of German farmers, seizure of German-owned industrial establishments and agricultural enterprises, and interference in the operation of minority schools. See German Settlers in Poland, Advisory Opinion, PCIJ Rep. Series B No. 6 (1923); Case Concerning Certain German Interests in Polish Upper Silesia (The Merits) (Germany v. Poland) PCIJ Rep. Series A No. 7 (1926); Case Concerning the Factory at Chorzón (Claim for Indemnity) (Merits) (Germany v. Poland) PCIJ Rep. Series A No. 17 (1928); Rights of Minorities in Upper Silesia (Minority Schools) (Germany v. Poland) PCIJ Rep. Series A No. 15 (1928); Case Concerning the Polish Agrarian Reform and the German Minority (Application for the Indication of Interim Measures of Protection) (Germany $v$. Poland) PCIJ Rep. Series A/B No. 58 (1933).

116 "Notification by the German Government of Its Intention to Withdraw from the League of Nations", C. 605. M. 282. 1933. V., 15 (1934) LNOJ 16.

${ }_{117}$ See, e.g., J. H. W. Verzijl, International Law in Historical Perspective, Vol. V (Leiden: Sijthoff, 1972) at 188.

118 See, e.g., Maurice Bourquin, Dynamism and the Machinery of International Institutions: A Critical Study of a Twenty Years' Experiment (Geneva: Geneva Research Centre, 1940) at 50.

119 As an influential commentator would later put it, minority protection was sapped of its legitimacy by the fact that it was "treated as a mere expedient, to be adopted with discriminatory effect, not as an expression of a
} 
I have already noted that the minority treaties and their accompanying machinery have often been understood to signal a radical augmentation of the minority protection provisions that were inserted into the balance-of-power treaties of the nineteenth century. I have also noted that this claim is frequently supported with a sharp distinction between pre- and post1919 international law. Hard-and-fast epochal divisions of this sort are nearly always misleading, and this certainly is a case in which positing an unbridgeable gap between the international law of the long nineteenth century and that of the interwar period would be misguided. Yet, once again, it cannot be denied that international law underwent far-ranging changes after Versailles. The rigid vision of absolute sovereignty found in so many of the classic nineteenth-century discussions of fully "civilized" states was relaxed somewhat after the war. Aiming for an efficient international distribution of territory while arbitrating the 1928 Island of Palmas dispute, Huber, for instance, could write that "the establishment of sovereignty may be the outcome of a slow evolution, of a progressive intensification of State control"120 - a depiction with which most pre-1919 treatise writers, accustomed to presenting European sovereignty as a cryptometaphysical "supreme power" or "supreme authority", 121 would have been somewhat uncomfortable, at least when discussing specifically intra-European affairs. ${ }^{122}$ The drive to institute minority protection regimes under the supervision of the League testified to the breadth of this change. Earlier attempts to extend protection to minorities or to regulate majority-minority relations appeared makeshift in comparison, outgrowths of temporary, unsustainable truces in a game of inter-imperial rivalry rather than harbingers of a properly

universally valid, normative approach to problems of human relations". Inis L. Claude Jr., National Minorities: An International Problem (Cambridge, MA: Harvard University Press, 1955) at 35. For contemporaneous engagement with the question, see H. B. Calderwood, "Proposed Generalization of the Minorities Regime" 28 (1934) American Political Science Review 1088.

${ }^{120}$ Island of Palmas (Netherlands $v$. United States) 2 RIAA 829 (1928) at 867.

${ }^{121}$ From an enormous literature, see, e.g., Henry Wheaton, Elements of International Law, With a Sketch of the History of the Science, Vol. I (London: B. Fellowes, 1836) at 9, 68-9, 136; Herbert Wolcott Bowen, International Law: A Simple Statement of Its Principles (New York: G. P. Putnam's Sons, 1896) at 3; Lassa Oppenheim, International Law: A Treatise, Vol. I, ed. Ronald F. Roxburgh, 2nd Ed. (London: Longmans, Green, \& Co., 1912) at 177.

122 The sovereign claims of extra-European states were generally subject to a significant degree of gradation in the hands of European jurists. In the case of the states comprising British India, for instance, it was believed that "[r]ather than signifying a quality that a state either possessed or failed to retain, sovereignty could be held by degrees, with full sovereignty reserved for the imperial power". Lauren Benton, A Search for Sovereignty: Law and Geography in European Empires, 1400-1900 (Cambridge: Cambridge University Press, 2010) at 245, 236-50 generally. For a similarly illuminating discussion, juxtaposing the development of doctrines of divisible sovereignty for the extra-European world and the consolidation of sovereign equality between European "civilized" states in the nineteenth century, see Edward Keene, Beyond the Anarchical Society: Grotius, Colonialism and Order in World Politics (Cambridge: Cambridge University Press, 2002), ch. 4. 
cosmopolitan future in which sovereignty might be modulated and calibrated to suit specific ends.

Part of this shift can be explained by a move towards a mode of pragmatism viewed as key to managing conflict, manufacturing viable states, and preventing the outbreak of yet another bellum omnium - again, with the important qualification that the twentieth-century turn to pragmatism was more an internal refinement of positivism, itself never entirely free from natural law, ${ }^{123}$ than a clean break from it. Writing in the American Political Science Review in 1926, one student of international relations argued that the League was "neither an anomaly nor a socalled superstate, but simply a corporation - that very convenient invention for getting joint business accomplished with which we are all familiar". ${ }^{124}$ This was a characterization that would have been all but unthinkable even a few years earlier and that clearly suggested sympathy with a managerialism derived from the United States' recently acquired great power status, not to mention Wilson's formative influence over the League project. The symbolic force - indeed, the very affective resonance - of ethno-nationalism needed to be controlled, to be utilized for other, more rational ends. "Suppress the League", wrote William Rappard, senior League diplomat, in 1925, "and you liberate instincts of domination, which are at present at least restrained. Fortify the League, on the other hand, and you bridle and repress these dangerous instincts which threaten not only the welfare of millions of Europeans, but thereby also the peace of the world." 125 Five years earlier another writer had been even more mellifluous: the "new world order" would be realized only if "international coöperation", understood both as "a matter of law" and as "a matter of policy, self-interest, and spiritual attitude", succeeded in taming violent nationalism, "so firmly fixed in the minds of men and the consciousness of states that we may not expect it to disappear". ${ }^{126}$

\footnotetext{
123 See Koskenniemi, Gentle Civilizer, supra note 77, at 130-2; and also Martti Koskenniemi, "Into Positivism: Georg Friedrich von Martens (1756-1821) and Modern International Law" 15 (2008) Constellations 189 at 190-1, 201-3. For an attempt to demonstrate that it was this tense relationship between positivism and naturalism that was responsible for the popularization of evolutionary and other forms of teleological thinking among late nineteenthcentury British international lawyers, see Casper Sylvest, "International Law in Nineteenth-Century Britain" 75 (2004) BYIL 9 at 12, 40-1, 48.

${ }^{124}$ Dayton Voorhees, "The League of Nations: A Corporation, not a Superstate” 20 (1926) American Political Science Review 847 at 847.

125 Rappard, supra note 101, at 56.

${ }^{126}$ Frederick Charles Hicks, The New World Order: International Organization, International Law, International Coöperation (Garden City, NY: Doubleday, Page \& Co., 1920) at 15-6.
} 
Such pragmatism had profound repercussions on the state. Already under attack, not least from political theories of polity formation growing out of the work of John Dewey and others, ${ }^{127}$ state sovereignty entered the increasingly disenchanted post-1919 world battered from war and bruised by calls for supranational institution-building. Jurists often spoke of "the growing interdependence of nations and the appearance of rudimentary organs of international government". ${ }^{28}$ For many, sovereignty could no longer be understood as purely as had once been the case: "Nous ne reconnaissons pas ce pouvoir", wrote one Japanese scholar in 1931, “comme absolu, c'est-à-dire comme illimité, bien que nous le considérions comme suprême, cestà-dire [sic] comme le plus élevé dans le domaine du droit interne". ${ }^{129}$ Though many jurists saw the emerging international legal order as supportive of - rather than inimical to - state sovereignty, ${ }^{130}$ even they tended to regard the absolutist strains in traditional conceptions of European sovereignty as increasingly untenable. The League sought, with varying degrees of success, to reconcile state sovereignty and world order under conditions which frequently blurred classical boundaries. ${ }^{131}$ One result was that the line between municipal and international law often became difficult to draw, as in the question of what could and could not be shielded from international legal scrutiny through characterization as a "matter of domestic jurisdiction" pursuant to Article 15 of the League Covenant ${ }^{132}$ - a provision of unstable scope and content even at the drafting stage. ${ }^{133}$ The new technologies of minority governance had a powerful role

127 A case in point is the "pluralistic theory of the State" proposed by the young Harold Laski in Studies in the Problem of Sovereignty (New Haven: Yale University Press, 1917) at 23-4. Even earlier, in the 1890s, Charles E. Merriam, founder of the Social Science Research Council and advisor to Presidents Hoover and Roosevelt, underscored the legal divisibility of sovereignty and the concomitant importance of the "semi-sovereign" in international law. C. E. Merriam, History of the Theory of Sovereignty since Roussean (New York: Columbia University Press, 1900) at 209-16.

128 S. W. Armstrong, "The Doctrine of the Equality of Nations in International Law and the Relation of the Doctrine to the Treaty of Versailles" 14 (1920) AJIL 540 at 563.

129 Sakutaro Tachi, "La souveraineté et le droit territorial de l'État" 38 (1931) RGDIP 406 at 408-9 (emphases mine). Cf. Cornélius Alexandre Rudesco, Étude sur la question des minorités de race, de langue et de religion (Lausanne: Librairie Payot \& Cie., 1928) at 97.

130 Such sovereignty would, they conceded, be curtailed in some respects, as in the minority treaties. But it would also feed off the protection it received from its immersion in a state system marked by greater security. See, e.g., Geoffrey Butler, "Sovereignty and the League of Nations" 1 (1920-1) BYIL 35 at 41.

${ }^{131}$ Cf. Baron Heyking, "The International Protection of Minorities - The Achilles' Heel of the League of Nations" 13 (1927) TGS 31 at 47.

132 Art. 15, para. 8 declared that "[i]f the dispute between the parties is claimed by one of them, and is found by the Council to arise out of a matter which by international law is solely within the domestic jurisdiction of that party, the Council shall so report, and shall make no recommendation as to its settlement". League Covenant, supra note 81 , at 134 .

133 Kelsen called this "one of the worst drafted provisions of the Covenant", rejecting outright the notion that "there are objects which by their nature escape from the control of international law". Hans Kelsen, Legal Technique 
to play here. By bolstering the "international community's" capacity to intervene in the newly established or reconstituted states of central and eastern Europe without going so far as to strip them of their formal sovereignty, it was hoped that the League would be able to mediate relations between the domestic and international spheres.

\section{Before and After the Exchange}

Considered superficially, Turkey's encounter with the interwar international law of minority protection seems conventional, more or less in keeping with experiences in central and eastern Europe after the fall of the Habsburgs, Hohenzollerns, and Romanovs. The Allies succeeded in inserting into the Lausanne Peace Treaty a set of provisions guaranteeing a slate of basic rights to Turkey's non-Muslim communities. These provisions were retailored, abbreviated variants of some of the protection clauses the Allies had built into the peace treaties with Poland and other states.

On closer inspection, though, what occurred in Turkey was quite distinctive. Although some of the Lausanne Peace Treaty's provisions had the same character as those in the central and east European minority treaties, this was not so much a case of straightforward, one-to-one transplantation as one of creative evolution. To begin with, the Turkish political elite flatly refused to extend legal minority status to Muslim communities. In this it followed the millet system, which had afforded certain non-Muslim communities a measure of autonomy but had not contemplated similar treatment for non-Turkish Muslim communities. In addition, those rights that were extended to non-Muslims were limited, in some cases quite severely. As a general rule, the minority provisions in the Lausanne Peace Treaty abridged the relevant portions of the European minority treaties. Finally, and most crucially, the system as a whole was made contingent on the Greek-Turkish population exchange. The Turkish delegation

in International Law: A Textual Critique of the League Covenant (Geneva: Geneva Research Centre, 1939) at $125,127$. Brierly claimed that domestic jurisdiction could not be restricted to "such generally non-controversial matters as a state's choice of constitution, its right to regulate immigration, tariffs, naturalization, and the like"; it also arguably involved issues "of a more contentious kind, such as the treatment of racial or linguistic or religious minorities, misgovernment producing repercussions in other states, selfish exploitation of undeveloped countries, unfair preferences in matters of traffic or customs, and innumerable others". J. L. Brierly, "Matters of Domestic Jurisdiction" 6 (1925) BYIL 8 at 13-4. For a more charged critique of the somewhat muddled conceptions of formal and substantive "universality" on which this and related provisions of the Covenant implicitly rely, see Georg Schwarzenberger, The League of Nations and World Order: A Treatise on the Principle of Universality in the Theory and Practice of the League of Nations (London: Constable \& Co., 1936), ch. 3. 
consented to the comparatively meagre minority protection clauses that were built into the Lausanne Peace Treaty only on the condition that the number of individuals to whom they could apply was curtailed through a compulsory population exchange. Turkish conformity to even the most rudimentary elements of the Versailles system of minority protection was thus tethered to the exchange's implementation. If the Lausanne peace settlement was "the international birth certificate of the new Turkey", ${ }^{134}$ the population exchange would exercise guardianship rights over minority protection in the new state.

These points require independent analysis. Members of the Turkish delegation at Lausanne tended to see themselves neither as heirs of a vanquished Central Power nor as forerunners of a new state with limited bargaining power, but as victors in a national liberation struggle seeking both to resist partition and to depose a despotic ancien régime. Turkey was finally to take its place in the "family of civilized nations" - not as a marginal participant, as in previous arrangements like the Treaty of Paris, but on its own terms, as an entity powerful enough to turn "civilizational" rhetoric to its advantage, ${ }^{135}$ even at the risk that this would entail further subordination to the West. ${ }^{136}$ And as with many other matters with serious politicoeconomic implications, like the question of how the concessions the Ottomans had granted to Western companies for the purpose of infrastructural projects such as railroad construction were to be handled, an especially thorny issue given the Turkish Republic's status as the Ottoman Empire's legal successor ${ }^{137}$ they pressed hard on the question of minority protection.

In the first instance, this position of perceived (if not actual) strength, departing markedly from the position Poland found itself in 1919, enabled the Turkish delegation to push

\footnotetext{
134 René Albrecht-Carrié, A Diplomatic History of Europe since the Congress of Vienna (New York: Harper \& Brothers, 1958) at 403.

135 Worth comparing, if only by way of analogy with a state typically characterized as a great power but bearing many of the hallmarks of a semi-peripheral entity, is the tendency of many Russian jurists of the time to couch Russia's war against Germany as a struggle for “civilization”. Eric Myles, “Humanity', 'Civilization' and the 'International Community' in the Late Imperial Russian Mirror: Three Ideas 'Topical for our Days"' 4 (2002) JHIL 310 at 329. For the broader dynamics, see Lauri Mälksoo, "The History of International Legal Theory in Russia: A Civilizational Dialogue with Europe” 19 (2008) EJIL 211.

${ }^{136}$ Cf. Benedict Kingsbury, "Sovereignty and Inequality" 9 (1998) EJIL 599 at 607; Yasuaki Onuma, "When was the Law of International Society Born? An Inquiry of the History of International Law from an Intercivilizational Perspective" 2 (2000) JHIL 1 at 21-2.

137 An instrument concluded at Lausanne established the Republic's successorship in regards to concessionary contracts and related agreements in territories not detached from Turkey: see Protocol relating to Certain Concessions Granted in the Ottoman Empire, signed at Lausanne, July 24, 1923, 28 (1924) LNTS 203, Arts. 1-2, at 203-4. For contemporaneous analysis, see Jean Teyssaire, "Les concessions et le traité de Lausanne" 35 (1928) RGDIP 447 at 459-62.
} 
the Allies on a problem of first-order importance - that of determining the meaning and scope of "minority" in the context at hand. The Allies suggested, if only half-heartedly, that "minority" should be understood in a broad sense, including, in addition to non-Muslims, those communities which shared the Islamic faith but were distinct from an ethnic, cultural, or linguistic standpoint from the Turkish majority. In response, Turkey sought to convince the Allies that minority status should be attached to non-Muslims alone. This, the Turkish delegation argued, would accord with realities on the ground. Centuries of living with the millet system had brought about a situation in which social relations were mediated first and foremost by distinctions of faith: Muslim and non-Muslim communities were distinguished legally in many respects. It would be pointless, and possibly counterproductive, to try to wipe the slate clean of this social residuum. A better option, the delegation intimated, was to work within it, making use of some of its elements to reconfigure existing social structures from the inside out. ${ }^{138}$ Leaving aside the fact that the Turkish argument about the embeddedness of the millet system was somewhat misleading (Ottoman authorities had begun to lay the groundwork for radical legal reforms before any of the Lausanne agreements were concluded), ${ }^{139}$ there was the fact that employing religion as the sole criterion for determining minority status flew in the face of established minority protection practices elsewhere.

Turkey's position on this issue proved insurmountable. Nowhere in the section of the Lausanne Peace Treaty concerning minority protection - comprised of Articles 37 through 44, with 45 added as a reciprocity clause vis-à-vis Greece to ensure the same treatment for Turkish Muslims in western Thrace ${ }^{140}$ - did the term "minority" appear unaccompanied by "nonMoslem". Article 39 declared that "Turkish nationals belonging to non-Moslem minorities will enjoy the same civil and political rights as Moslems", Article 40 granted members of these same communities the right to "establish, manage and control at their own expense any charitable, religious and social institutions", Article 41 obligated the state to make instruction in native languages available in "those towns and districts, where a considerable proportion of nonMoslem nationals are resident", and so on. At no point in these or any other provisions were

\footnotetext{
${ }^{138}$ For the legal context and ultimate fallout, see infra Chapter III notes 157-9 and accompanying text.

139 For brief but useful surveys, see Niyazi Berkes, The Development of Secularism in Turkey (Montreal: McGill University Press, 1964), ch. 13; Stanford Shaw and Ezel Kural Shaw, History of the Ottoman Empire and Modern Turkey, Vol. II (Cambridge: Cambridge University Press, 1977) at 305-10.

140 Treaty of Peace, signed at Lausanne, July 24, 1923, 28 LNTS 11 at 31-7.
} 
similar entitlements extended to non-Turkish Muslims. In each case, the term "minority" was qualified by the immediately preceding term, "non-Moslem".

That minority status was understood along these lines followed directly from the Ottoman millet system. Not only did the Peace Treaty contain no stipulation to the effect that Turkey recognize any of its non-Turkish Muslim communities as national minorities, but it effectively restricted the application of minority status to those non-Muslim communities which had traditionally commanded dominant positions within the millet system: the Greeks, Armenians, and Jews. ${ }^{141}$ Religion had been the primary formal marker of identity under the millet system, and Muslims had only rarely, and exceptionally, been distinguished along ethnic lines for purposes of legal administration. Even as late as 1912, a British diplomat could still write that "[a]ll Musulmans, whether Shia or Sunni, Turk, Arab or Kurd, are simply entered on the register as 'Moslems"'. ${ }^{142}$

As has so often been the case, it was the Kurds - the most sizable non-Turkish group inhabiting the territory that would soon comprise the Turkish Republic ${ }^{143}$ - who bore the brunt of this restriction. Not only were the Kurds overwhelmingly Muslim, but most were affiliated with the same school of Sharía - the Hanafī school - as the majority of Turks. The Kemalists had made a point of peddling the "Turkey" of the future as a home for Turks and Kurds alike during the Greek-Turkish War, with Mustafa Kemal himself resorting to the rhetoric of panIslamic solidarity in order to galvanize the anti-imperialist cause. Indeed, leaning on shared religious affiliations, the Kemalists had often presented themselves as future governors of a federal, consociational "land of Turks and Kurds" during the course of the war. ${ }^{144}$ But at Lausanne, earlier promises of regional autonomy and eventual independence to Kurds, for which provision was made in the unratified 1920 Treaty of Sèvres, ${ }^{145}$ were laid aside; most Turkish nationalists viewed these promises as tantamount to an attempt to splinter their

141 Baskın Oran, Türkiye'de Az̧nlıklar: Kavramlar, Teori, Lozan, İc Mevzuat, İctihat, Uygulama (İstanbul: İletişim, 2004) at 47-60.

142 Quoted in Mark Mazower, The Balkans: A Short History (New York: The Modern Library, 2002) at 41.

143 The Republic's first census, conducted in 1927 and including details on religious affiliations and native languages, some for the first time, put the total number of Kurds at nearly 1,200,000, or approximately $10 \%$ of the total population. See A. A. Pallis, "The Population of Turkey in 1935" 91 (1938) Geographical Journal 439 at 442.

144 See, e.g., Bülent Gökay, "The Kurdish Question in Turkey: Historical Roots, Domestic Concerns and International Law" in Nazila Ghanea and Alexandra Xanthaki, eds., Minorities, Peoples, and Self-Determination: Essays in Honour of Patrick Thornberry (Leiden: Nijhoff, 2005) 315 at 321.

145 Treaty of Peace between the Allied Powers and Turkey, signed at Sèvres on August 10, 1920, 15 (1921) AJIL Sup. 179, Arts. 62-4, at 192-3. 
country, and refused flatly and consistently to accept them. ${ }^{46}$ The Kurds were not alone in this regard. Arabs, present in large numbers in southeastern Anatolia, and a number of other Muslim groups, such as Albanians, Bosnians, and Circassians who had found refuge on Ottoman soil after being forced out of the Balkans and Caucasus from the third quarter of the nineteenth century onwards, were denied minority status. Despite the fact that some such groups, like the Circassians, were often highly resistant to Turkish nationalism, ${ }^{147}$ they were widely deemed amenable to assimilation. Potentially even more threatening from the Kemalists' standpoint, if the Turkish delegation had not appended the modifier "non-Moslem" to references to minorities throughout the Lausanne Peace Treaty, but instead contented itself with more generic references to "religious minorities", groups like the Alevi - a quasi-Shi'i sect commanding the allegiance of a fifth of all Muslims in Turkey even today ${ }^{148}$ - may have qualified as minorities under international law. ${ }^{149}$ Turkey's position departed from most accounts of nationhood in circulation after the First World War, which generally privileged shared ethnic, cultural, and linguistic bonds over explicitly, or exclusively, religious sources of social identification. ${ }^{150}$

Second, even if one brackets the question of religion, one cannot help but be struck by the fact that those provisions that did make their way from the minority treaties to the Lausanne Peace Treaty were nearly always diluted. To be sure, both in style and in substance, most of

${ }^{146}$ For revealing glosses from a doyen of international legal academia (and the editor of the Conference of Lausanne's Turkish-language minutes), see Seha L. Meray, Devletler Hukukuna Giriss, Vol. I (Ankara: Ajans-Türk Matbaas1, 1959) at 51, 191 ff. On the background dynamics, see David McDowall, A Modern History of the Kurds (London: Tauris, 1997) at 137-43; Wadie Jwaideh, The Kurdish National Movement: Its Origins and Development (Syracuse: Syracuse University Press, 2006) at 133-8; Jean Allain, International Law in the Middle East: Closer to Power than Justice (Aldershot: Ashgate, 2004) at 18-9.

${ }_{147}$ Ryan Gingeras, Sorronful Shores: Violence, Ethnicity, and the End of the Ottoman Empire, 1912-1923 (Oxford: Oxford University Press, 2009), esp. chs. 4, 5.

148 Though the Alevis were not subject to group persecution at the time, some Turkish nationalists feared that they would exert a destabilizing influence. See, e.g., Hamit Bozarslan, "L'alévisme et l'impossible équation du nationalisme en Turquie" in Alain Dieckhoff and Riva Kastoryano, eds., Nationalismes en mutation en Méditerranée orientale (Paris: CNRS Éditions, 2002) 133 at 139. The reluctance of many Turkish nationalists to countenance protection for Muslim groups like the Alevis followed not simply from a desire to maintain high levels of social cohesion, seen widely as requisite for political unity and independence, but also from long-standing disputes regarding their fundamental allegiances. The Alevis were the subject of political and confessional wrangling between the Ottomans and Safavids for centuries - a conflict in which they were frequently less pawns than strategically conscious players. Ayfer Karakaya Stump, "Subjects of the Sultan, Disciples of the Shah: Formation and Transformation of the Kizilbash/Alevi Communities in Ottoman Anatolia", Ph.D. dissertation, Harvard University (2008).

${ }^{149}$ Baskın Oran, "The Minority Concept and Rights in Turkey: The Lausanne Peace Treaty and Current Issues" in Zehra F. Kabasakal Arat, ed., Human Rights in Turkey (Philadelphia: University of Pennsylvania Press, 2007) 35 at 37.

${ }^{150}$ Cf. Preece, supra note 106, at 72. 
these provisions echoed those in the central and east European minority treaties: Articles 37, 38, 39, 40, and 44 of the Lausanne Peace Treaty were, for instance, near-identical reproductions of Articles 1, 2, 7, 8, and 12 of the Polish Minority Treaty respectively. ${ }^{151}$ Be that as it may, important divergences persisted. And though some of these divergences appeared at first blush to involve stringent requirements tailored specifically to the Turkish context, the procedural mechanics they generated nearly always stood in the way of their successful implementation. More often than not, in fact, they valorized rather than constrained state power.

A striking, and exceptionally important, illustration is provided by Article 42. With this provision, Turkey undertook "to take, as regards non-Moslem minorities, in so far as concerns their family law and personal status, measures permitting the settlement of these questions in accordance with the customs of those minorities". ${ }^{152}$ On its face, it laid the groundwork for special legal instruments for non-Muslims in regards to a sensitive set of social relations, thereby limiting the reach of the new Turkish state. It is not hard to see that this too was something of a continuation of the Ottoman millet system. Just as this system had preserved a certain sphere of internal autonomy for non-Muslim communities in regards to family law, so the "new Turkey" was to ensure that these communities would determine the character of a great many legal structures to which they would be subjected as citizens of the Turkish Republic. A systematically revamped legal system, one grounded in new codes which had been imported from continental Europe, was to be fashioned. And this process would not unfold behind the backs of Turkey's Christians and Jews. Instead, it would include them in every stage of the requisite preparatory work.

Yet, this was not the entire story. Article 42 proved to be the most problematic of the various provisions that were bundled together under the rubric of minority protection in the Turkish peace treaty. This was due to the fact that it involved an intriguing, and somewhat impractical, procedure for regulating legal reform - namely, establishing "special commissions composed of representatives of the Turkish Government and of representatives of each of the minorities concerned in equal number" to review relevant proposals. "In case of divergence" in regards to the pace or trajectory of legal reform, it went on to explain, "the Turkish Government and the Council of the League of Nations will appoint in agreement an umpire

${ }^{151}$ Lausanne Peace Treaty, supra note 140, at 31, 33; Polish Minority Treaty, supra note 91, at 416-9.

152 Lausanne Peace Treaty, supra note 140, at 35. 
chosen from amongst European lawyers" to negotiate a compromise and settle the issue. ${ }^{153}$ Unsurprisingly, the work of these commissions - indeed, their very existence - proved divisive, with government officials being at pains to find pretexts for their liquidation and many members of the millets-turned-minorities themselves expressing doubts as to their usefulness. In 1925, two years after Lausanne and one year after the entry into force of the first full constitution of the Turkish Republic, these committees informed the Turkish ministry of justice that they no longer saw any reason why their activities should continue. Evidently the Turkish state's decision to overhaul its constituent legal structures, particularly its decision to press ahead with new legal codes, had convinced them that they would be afforded much the same civil and political entitlements they would otherwise have pursued through alternative means. Crucially, a significant amount of pressure had been applied to the representatives of these nonMuslim communities to achieve such conformity. First with the Jewish community, perceived to be the most "faithful" of the lot and the least likely to resist further Turkification, ${ }^{154}$ then with the Armenians and Greeks, the state had curtailed the activities of specialized educational institutions $^{155}$ and co-opted or replaced minority representatives, going as far as to arrest recalcitrant committee members in some cases. ${ }^{156}$ What began as a putative attempt to salvage bits and pieces of Ottoman pluralism thus turned into a full-blown programme in neo-Jacobin centralization, ${ }^{157}$ a key component of a drive to subordinate minorities to the sovereignty of the new state. ${ }^{158}$ As Aktar observes, with this move, "non-Muslim citizens were stripped of all the

\footnotetext{
153 Ibid.

${ }^{154}$ Descendants of Iberian Sephardim who had been resettled in the Empire after fleeing the Inquisition, Ottoman Jews were often favoured by authorities in Istanbul on account of their loyalty. See, e.g., Feroz Ahmad, "Unionist Relations with the Greek, Armenian, and Jewish Communities of the Ottoman Empire, 1908-1914" in Braude and Lewis, Vol. I, supra note 54, at 401, 402-3, 425-8. The feelings were mutual. In 1915, for instance, at the height of the Armenian genocide, Henry Morgenthau, the American ambassador in Istanbul, received assurances from Ottoman authorities that Jews would be afforded special protection. For legal discussion, see A. M. K. Rabinowicz, "Classical International Law and the Jewish Question" in H. Meijers and E. W. Vierdag, eds., Essays on International Law and Relations in Honour of A. J. P. Tammes (Leyden: Sijthoff, 1977) 205 at 225.

155 Aron Rodrigue, French Jews, Turkish Jews: The Alliance Israélite Universelle and the Politics of Jewish Schooling in Turkey, 1860-1925 (Bloomington: Indiana University Press, 1990) at 162-6.

156 Samim Akgönül, Türkiye Rumlar: Ulus-Devlet Çăğndan Küreselleşme Cağına Bir Ažnliğm Yok Oluş Süreci, tr. Ceylan Gürman (İstanbul: İletişim, 2007) at 69-74.

157 Cf. Birol Caymaz, Türkiye'de Vatandaşlık: Resmî İdeoloji ve Yansımalar (İstanbul: İstanbul Bilgi Üniversitesi Yayınlar1, 2007) at 27.

${ }^{158}$ For a strong expression of the prevailing sentiment among Turkish jurists, see Y1lmaz M. Altuğ, Turkey and Some Problems of International Law (İstanbul: Yenilik Basımevi, 1958) at 153 (arguing that " $\mathrm{t}$ ] he minority is subordinate to the sovereignty of the state and it must respect the juridical order on which its rights depend".).
} 
distinctions that came with belonging to a religious and ethnic community whose security was guaranteed by international agreements and 'legally' Turkified”. ${ }^{159}$

Seeing as how the Polish Minority Treaty had served as a standard-bearer for later minority treaties, and that portions of these treaties had, in turn, filtered into most international legal instruments of the time, the fact that similarities should have existed between it and the Lausanne Peace Treaty is not especially noteworthy. What is noteworthy is that Lausanne's relevant provisions were weaker, not being backed up with vigorous mechanisms of international protection. "Of the nationality provisions of the Peace Treaties, those of the Lausanne Treaty" were, a contemporaneous scholar wrote, "the most defective"; despite flimsy assurances of referral to the League Council, "the authority permitted to Turkey for promulgating such Nationality Laws as she pleases" was essentially "supreme". ${ }^{160}$ So removed was Turkey from east-central Europe's minority protection paradigm that Erik Colban, head of the League's Minorities Section, asserted that "the minorities procedure adapted for the European States does not give the desired result when applied to Turkey". ${ }^{161}$

Third, many of the minority protection instruments that were built into the Lausanne Peace Treaty were rendered moot by the fact that this agreement was concluded half a year after the Convention concerning the Exchange of Greek and Turkish Populations, appended, as mentioned earlier, to the Peace Treaty as part of the package of international legal agreements that came to comprise the general peace settlement. The importance of this chronology cannot be overstated. The Convention of Lausanne set out the basic parameters of the exchange, establishing an internationally staffed institution (the "Mixed Commission") to supervise the movements of those displaced and dispense compensation for losses incurred during their unfolding. It was understood by all parties to the Lausanne negotiations, and with especial force by Turkish delegates, to be a prerequisite not simply to the conclusion of a lasting peace, but to the resolution of the general "minorities problem". ${ }^{162}$ Had it not been for this agreement, it was

\footnotetext{
${ }^{159}$ Ayhan Aktar, “Cumhuriyetin İlk Yıllarında Uygulanan 'Türkleştirme' Politikaları” in Ayhan Aktar, Varlık Vergisi ve "Türkleștirme” Politikalar (İstanbul: İletişim, 2000) 101 at 113 (translation mine).

160 William O'Sullivan Molony, Nationality and the Peace Treaties (London: Allen and Unwin, 1934) at 101.

161 Quoted in Martin Scheuermann, Minderheitenschutz contra Konfliktverbütung? Die Minderheitenpolitik des Völkerbundes in den zwanziger Jahren (Marburg: Verlag Herder-Institut, 2000) at 366-7, 369. Scheuermann analyzes the Minorities Section's assessment of petitions emanating from or related to Turkey, and argues that "[i]n no other country did international diplomatic interventions in regards to minority questions remain as weak and ineffective as they did in Turkey". Ibid., at 345, 344-70 generally (translation mine).

162 See the discussion in Chapter III.
} 
widely assumed that the prospects of achieving peace would have been slim to none. ${ }^{163}$ And since the exchange "cleansed" Turkey of the vast majority of its remaining non-Muslim population, it also reduced the relevance of Lausanne's minority protection provisions to an exceedingly small segment of the Turkish Republic's citizenry. Almost negligible in numbers, the minorities comprising this segment could thenceforth be coerced or cajoled into toeing the line favoured by the Turkish-Muslim majority all the more easily. The Allies had originally sought to partition Asia Minor along ethno-confessional lines. Intelligence reports prepared for the Paris Peace Conference had recommended the creation of a truncated Turkish state in central Anatolia, suggesting that with its "solid block of Turkish Moslems", this region would serve as a natural home for any post-Ottoman Turkey, "not the least of its assets" being "freedom from the burden of governing alien peoples of different faith, whose oppression by the Turk has reacted upon him morally and politically, with well-known evil effects". ${ }^{164}$ This recommendation had been heeded by the drafters of the Treaty of Sèvres, which, among other things, had envisioned a "national home" for Armenians and autonomy (with the prospect of potential future independence) for Kurds. ${ }^{165}$ Seeing as how this project had come to naught, it was now believed that stable, peace-abiding nation-states could be constructed in the Near East by way of a full-scale population exchange that would achieve the goals of minority protection by other means.

What one sees in all this is the normative architecture of interwar international law straining to develop an adequate mechanism to contain ethno-nationalist conflict in a unique region. Short of a mandate, the population exchange was the most brutal - and brutalizing method of establishing order available at the time. As will be discussed in Chapter Three, nearly all those with a hand in designing the Greek-Turkish exchange voiced their discomfort at one point or another. And many jurists of the period recognized it as a significant departure from minority protection. "The Lausanne agreement", one student of the exchange would write a few years later, "does not comply with the new principles of minority protection" but "proposes an

\footnotetext{
163 Baskin Oran, "The Story of Those who Stayed: Lessons from Articles 1 and 2 of the 1923 Convention" in Renée Hirschon, ed., Crossing the Aegean: An Appraisal of the 1923 Compulsory Population Exchange between Greece and Turkey (New York: Berghahn, 2003) 97 at 97.

164 "Outline of Tentative Report and Recommendations Prepared by the Intelligence Section, in Accordance with Instructions, for the President and the Plenipotentiaries, January 21, 1919”, as reproduced in David Hunter Miller, My Diary at the Conference of Paris, with Documents, Vol. IV (New York: Appeal Printing, 1924) 209 at 257.

165 Treaty of Sèvres, Arts. 62-4, 88-93, supra note 145, at 192-3, 198-9.
} 
entirely different way". ${ }^{166}$ Redslob was even sharper, arguing that the population exchange, while useful as a means of forging "l'unité nationale", flouted conventional minority protection protocols: "L'option entre le sol et la famille nationale, cette option qui est aujourd'hui concédée dans chaque traité de paix en vertu d'un droit coutumier, elle n'est pas accordée dans le Pacte de Lausanne". ${ }^{167}$ Nevertheless, the sentiment that recourse needed to be had to a compulsory exchange if the region was to stand a chance of achieving stability was a widely shared one. If Greeks and Turks remained "mixed", sectarian violence would almost certainly spiral further out of control. Hence the felt need for a concomitantly bold "solution" to the "problem" - a need felt as much by Turkish as by Greek and Allied authorities. Nation-building called for strict control over territories and populations, the fortification of peace by power. A compulsory exchange was needed to realize the objectives for which minority protection had been developed.

166 Leonidas Leontiades, "Der griechisch-türkische Bevölkerungsaustausch" 5 (1935) ZaöRV 546 at 552 (translation mine). See also Georgios S. Streit, Der Lausanner Vertrag und der griechisch-türkische Bevölkerungsaustausch (Berlin: Georg Stilke, 1929) at 24.

167 Robert Redslob, Le principe des nationalités: les origines, les fondements psychologiques, les forces adverses, les solutions possibles (Paris: Sirey, 1930) at 166, 168. 


\section{CHAPTER II.}

\section{En Route to the Exchange:}

\section{Demographic Engineering in the Near East, 1913-9}

In 1954, in the wake of the Second World War-era popularization of population transfers, Thomas Baty, noted British jurist and adviser to the Japanese government, observed that the word "state" lent itself to two distinct interpretations. The first envisioned the state as an independent sovereign entity, the other as the economic and social organization requisite for the existence of this entity - the state's national bedrock and precondition. Each interpretation illuminated something essential about the concept of the state. And each was hardwired into its genealogy. "[N]ot only", wrote Baty, "has the word 'state,' now used as a technical term of international law, connotations of ideas of pompous magnificence on the one hand, and mere 'condition' on the other, but ... it has actually been derived etymologically from ... both of the two". ${ }^{1}$

Baty's sensitivity to the ambiguity of the term had been shared by others for some time. ${ }^{2}$ In fact, only a few years earlier, in Der Nomos der Erde, Carl Schmitt had concluded an analysis of a sentence from book one of Rousseau's $D u$ contrat social with the observation that Rousseau made full use of the ambivalence inherent in the French état. Since this word's first character may be written in upper as well as in lower case - the former being the traditional form for the state as an independent sovereign, the latter generally being used as a placeholder for a particular condition (as in l'état de droit) - Rousseau's decision to retain the lower case for the one sense just as much as for the other was, he suggested, both politically charged and theoretically significant. The state, Rousseau seems to have been insinuating, ought not to be absolutized. ${ }^{3}$ In Schmitt's eyes, though, this move - a most "perplexing and almost primitive artifice" - obfuscated statehood's solemnity, obliterating at one stroke "the whole rationalizing

\footnotetext{
${ }^{1}$ Thomas Baty, International Law in Twilight (Tokyo: Maruzen Co., 1954) at 311.

2 See, e.g., H. C. Dowdall, "The Word 'State” 39 (1923) LQR 98.

${ }^{3}$ For a brief discussion, see "A Note on the Translations" in Jean-Jacques Rousseau, The Social Contract and Other Late Political Writings, ed. Victor Gourevitch (Cambridge: Cambridge University Press, 1997) xliv at lii-liv.
} 
power of the concept 'state"'. Un État should never be conflated with un état, he emphasized, least of all for the sake of "word-play".

The internal connection between these two denotations of "state" - the one underscoring the sovereignty essential to the state's political power and legal authority, the other speaking to the national preconditions for the exercise of such sovereignty - is clearly discernible in the transfers and exchanges carried out in the Near East during the 1910s. Each of these movements was driven by the need - felt widely among the relevant countries' statesmen - to align ethnicity with territory, nation with state, more closely than had previously been the case. Absent such an alignment, such a subsumption of état under État, prospects for peace in the Near East would remain remote; ethno-nationalism would not facilitate stateformation efforts so much as hamper them.

As late as 1928, one finds Stelios Seferiades, a leading Greek jurist of the interwar period, arguing that the expression "population exchange" was "complètement nouvelle dans l'histoire des traités". ${ }^{6}$ Nevertheless, the Greek-Turkish exchange needs to be understood as the culmination of a series of earlier experiments in demographic engineering in the Near East. Though these antecedents were small in scale, local in scope, generally voluntary in character, and not always implemented fully, they supplied the parameters within which the later endeavour would be designed. Once it became clear that the minority protection instruments employed in central and eastern Europe after 1919 would not be enough to put an end to conflict in the Near East, the techniques which had been developed during these experiments were channelled into the final - compulsory and comprehensive - exchange that was undertaken between Greece and Turkey.

This chapter sets the stage for the in-depth analysis of the Greek-Turkish exchange that follows in Chapters Three and Four. Its purpose is twofold: to situate the Greek-Turkish exchange in a body of international treaty law relating to transfers and exchanges developed in the 1910s, and to explain the socio-political preconditions of demographic engineering in the

\footnotetext{
${ }^{4}$ Carl Schmitt, The Nomos of the Earth in the International Law of the Jus Publicum Europaeum, tr. G. L. Ulmen (New York: Telos, 2003 [1950]) at 149-50.

${ }^{5}$ Ibid., at 150. Dismissing this as an idiosyncrasy, or as a trivial illustration of Schmitt's politics, elides the fact that it recruits a broadly post-Hegelian conception of the state as the guarantor of the common good - a conception that was influential in anti-liberal circles during the late nineteenth and early twentieth centuries. See especially Quentin Skinner, "States and the Freedom of Citizens" in Quentin Skinner and Bo Stråth, eds., States and Citizens: History, Theory, Prospects (Cambridge: Cambridge University Press, 2003) 11 at 21-2.

6 Stelio Séfériadès, "L'échange des populations" 24 (1928-IV) RCADI 307 at 335.
} 
Near East during the second decade of the twentieth century. I first examine a number of late Ottoman experiments in demographic engineering. I then consider the social and political context within which these enterprises took place. The two elements of my analysis are intertwined: understanding the movements of the 1910s demands an investigation into the forces at work in the crystallization and normalization of a specifically Turkish nationalism in the late Ottoman Empire; similarly, it is only by examining the body of treaty law through which these movements were formalized that such nationalism's relationship with law can be appreciated.

\section{Early Experiments in Demographic Engineering}

Ottoman rulers had shifted communities from one province to another by force for centuries, usually to consolidate political power and further administrative control. Indeed, while the practice of relocating select non-Muslim children to Istanbul for training as members of the sultan's elite order of Janissary guards - termed devssirme, literally "collection" - was abolished in the late sixteenth century, ${ }^{7}$ settling Muslims from Anatolia in southeastern Europe through mass deportations (sürgüns) was a practice employed well into the nineteenth century. ${ }^{8}$ Rulers of newly independent or quasi-independent states in the Balkans - where such deportations came to be seen as key to the region's politico-economic "backwardness" - returned the favour in the nineteenth century by expelling many of their Muslims inhabitants. ${ }^{10}$ Nevertheless, despite the residual influence of these practices and the floating of similar proposals, ${ }^{11}$ it was not until

\footnotetext{
7 See, e.g., Stanford J. Shaw, History of the Ottoman Empire and Modern Turkey, Vol. I (Cambridge: Cambridge University Press, 1976) at 113-4.

${ }^{8}$ For an influential discussion of "deportation and emigration as a tool of reorganization" during the Empire's classical period, see Halil İnalc1k, "Ottoman Methods of Conquest” 2 (1954) Studia Islamica 103 at 122-9. Interestingly, though such practices were condemned by many, they were not subject to across-the-board denunciation. Writing in the early sixteenth century, Machiavelli, for example, famously lauded Ottoman "direct rule" (by which he seems partly to have meant mass resettlement) as "[o]ne of the best and most effective solutions" to the problem of holding and administering conquered territory. Niccolò Machiavelli, The Prince, ed. Quentin Skinner and Russell Price (Cambridge: Cambridge University Press, 1988 [1532]) at 8-9.

9 See, e.g., Wayne S. Vucinich, "The Nature of Balkan Society under Ottoman Rule" 21 (1962) Slavic Review 597 at $606 \mathrm{ff}$. And for a classic survey of the political economy of Ottoman rule in the Balkans that accords great significance to this perspective, see Perry Anderson, Lineages of the Absolutist State (London: Verso, 1979) at 361-94. 10 See, e.g., Nedim İpek, Rumeli'den Anadolu'ya Türk Göcleri (1877-1890) (Ankara: Türk Tarih Kurumu Basımevi, 1994); Justin McCarthy, Death and Exile: The Ethnic Cleansing of Ottoman Muslims, 1821-1922 (Princeton: Darwin Press, 1995).

11 At the peace talks that followed the Russo-Turkish War of 1877-8, Grand Vezier Saffet Paşa had proposed that Muslims north of the Balkan mountains be exchanged with Bulgar Christians south of the mountains. The
} 
the first decades of the twentieth century that transfers and exchanges appeared on the scene in the form of international movements juridified at least partly by bilateral and multilateral treaties. Indeed, moving over the terrain that commences with the First Balkan War in 1912 and concludes with the cessation of hostilities growing out of the Greek-Turkish War in 1922, one cannot help but notice the appearance of a new form of statecraft - the last-ditch measure of mass expulsion. Premised on demographic engineering, this new mode of nation-building quickly acquired the reputation of an effective, if still not entirely palatable, instrument of statecraft in the region. ${ }^{12}$ If, as one commentator wrote of the Balkan Wars' conclusion, "the end of the Ottoman Empire, long foreseen and long dreaded as the certain prelude to Armageddon, had come, and come in the best possible way", with "young nations of high promise" having "been brought to the birth", 13 then population movements governed at least partly by international law played a key role in facilitating this transformation.

The first attempt to coordinate an exchange of populations in the Near East took place in 1913. Following the Ottoman army's defeat in the First Balkan War in the face of a joint attack from Bulgaria, Greece, and Serbia, approximately 400,000 Muslims (many, but not all, ethnic Turks) had fled eastward from Bulgaria, some being resettled in Istanbul and others transferred to hinterland provinces in Anatolia. In addition to this mass dispersion, though, large numbers of ethnic Turks and Bulgarians living near the border between the two states, totalling roughly 50,000 in each case, had fled eastward and westward across the Maritza, the river demarcating the historic boundary between western and eastern Thrace (and, today, Greece and Turkey). ${ }^{14}$ Determined to address the problems which had been caused by this displacement - one in a series of mass migrations after Bulgaria achieved formal independence in $1908^{15}$ - Bulgarian and Ottoman authorities agreed to oversee a population exchange in areas

proposal had been rejected by the Russians. Fuat Dündar, Ittibat ve Terakki’nin Müslümanlar İkân Politikası (19131918) (İstanbul: İletişim, 2001) at 67.

${ }^{12}$ For an argument to the effect that early twentieth-century population movements were driven by fundamentally new methods of identifying social groups and designing policy, grounded above all in ethno-nationalism, see Reşat Kasaba, A Moveable Empire: Ottoman Nomads, Migrants, and Refugees (Seattle: University of Washington Press, 2009) at $136 \mathrm{ff}$.

${ }^{13}$ J. A. R. Marriott, The Eastern Question: An Historical Study in European Diplomacy (Oxford: Clarendon Press, 1917) at 407.

14 This was a long-contested area, even housing a short-lived "Republic of Pomaks" (Pomaks being Bulgarianspeaking Muslims) between 1876 and 1886. A.-G. Drandar, Les événements politiques en Bulgarie depuis 1876 jusqu'a nos jours (Bruxelles: Librairie européenne C. Muquardt, 1896) at 373-81.

${ }^{15}$ For the circumstances under which independence was declared, see R. J. Crampton, Bulgaria (Oxford: Oxford University Press, 2007) at 174-9. A full third of Bulgaria's population appears to have been Muslim (the majority 
immediately abutting the border for the remaining population. ${ }^{16}$ This exchange was to confer retroactive legitimacy upon the movements which had already taken place, and, though formally a voluntary affair, it was also to encourage those who remained to move without delay; Bulgarian Muslims - a group whose legal status had long been somewhat ambiguous ${ }^{17}$ - were, for instance, to be provided with the option of remaining Bulgarian subjects or leaving for Ottoman territory and thereby becoming subjects of the sultan. ${ }^{18}$ What is more, it was to be undertaken under the auspices of a mixed (i.e. Bulgarian-Ottoman) commission established for the sake of maintaining order along the border. The outbreak of the First World War ultimately blocked the implementation of the agreement, but it served as a generic, somewhat rough-andready model for the exchanges that would follow in the Balkans in the years to come.

The instrument governing the exchange - a protocol to the general peace treaty that had been signed between the two countries after the war - made it clear that the exchange was intended to bolster the power of the state over the people inhabiting the outer limits of its territory. The governments of the two states were to oversee a process of societal tinkering that was already underway, reaching agreement "pour faciliter l'échange facultatif mutuel des populations bulgare et musulmane de part et d'autre ainsi que de leurs propriétés dans une zone de 15 kilom. au plus, le long de toute la frontière commune". ${ }^{19}$ And it was the mixed commission established pursuant to the protocol ${ }^{20}$ that was to do much of the heavy lifting, being entrusted with the responsibility of managing the movement of peoples and overseeing indemnification efforts. Though spatially circumscribed and a by-product of broader conflict between regional rivals, the exchange struck at the heart of the aspirations of modernizing elites

ethnically Turkish) in 1908, a fact which predictably engendered considerable anxiety among Bulgarian nationalists. Yonca Köksal, "Minority Policies in Bulgaria and Turkey: The Struggle to Define a Nation" 6 (2006) Southeast European and Black Sea Studies 501 at 506.

${ }^{16}$ For the text of the treaty, see Treaty of Peace between Bulgaria and Turkey - Constantinople, September 16 (29), 1913, 107 BFSP 706.

17 At the time Bulgarian officials often presented the Pomaks as Bulgarians in all but faith; see, e.g., Délégation bulgare à la Conférence de la Paix, Exposé sur la question de la Thrace occidentale (n.p.: 1919) at 2. This was resisted by many Turkish nationalists, as well as by large numbers of Pomaks themselves.

18 Peter Loizos, “Ottoman Half-Lives: Long-Term Perspectives on Particular Forced Migrations” 12 (1999) Journal of Refugee Studies 237 at 239. It should be noted that this was, among other things, one in a series of moves by Bulgaria to exercise greater control over its Turkish minority after 1908 - others being the transformation of highranking imams into fully fledged state functionaries and the institution of strong mechanisms of supervision over Turkish schools. André Girard, Les minorités nationales ethniques et religieuses en Bulgarie (Paris: Marcel Giard, 1933) at 53-4.

19 Turkish-Bulgarian Peace Treaty, supra note 16, at 714.

20 "Des commissions mixtes nommées par les deux Gouvernements procéderont à l'échange et à l'indemnisation, s’il y a lieu, de différences résultant de l'échange de biens entre villages et particuliers en question.” Ibid. 
to win recognition as leaders of genuinely modern nation-states - states wielding distinct national identities and capable of exercising effective control over their respective territories and populations.

This first effort was followed by another in 1914. In 1913 forces under the command of high-ranking officials within the Ottoman governing elite had been instructed to have large numbers of Greek farmers and townspeople abandon their homes on the Aegean coast, leaving them little choice but to seek refuge on nearby islands controlled by Greece. This move was roughly coincidental with the persecution of Muslim peasants in western Thrace by Greeks who had fled Ottoman territory during the 1912-3 Balkan Wars, but, understandably, it met with considerable indignation - in Greek $^{21}$ as well as in west European ${ }^{22}$ circles. In 1914, by which time Ottoman authorities had expelled no less than 100,000 Greeks from the Aegean littoral, ${ }^{23}$ a number of authorities in Athens, most prominently Venizelos, Greece's prime minister at the time, and Galip Kemâli Bey, a counsellor to the Ottoman embassy in Athens, took steps to stabilize the situation and render the previous moves permanent by negotiating a voluntary exchange between the Muslims of Greek Macedonia and the ethnic Greeks of the Aegean coastal province of Aydin. As before, the exchange was to be administered by a mixed commission. This initiative too came to nothing, though, with the outbreak of the First World

\footnotetext{
${ }^{21}$ While negotiating the protocol, Kemâli Bey reported that the Greek foreign minister had told him that the state in Greece was such that, absent Turkish cooperation on a coordinated exchange, it would be "impossible au Gouvernement hellénique contenir opinion publique", as the influx of 50,000 Greek refugees had produced "une perturbation dans les affaires intérieures et financières" of the country. "S. E. Ghalib Kémaly Bey, Ministre ottoman à Athènes, à S. A. Saïd Halim Pacha, Grand Vizir et Ministre des affaires étrangères ottoman - Athènes, le 14 juin 1914" and "S. E. Ghalib Kémaly Bey, Ministre ottoman à Athènes, à S. A. Saïd Halim Pacha, Grand Vizir et Ministre des affaires étrangères ottoman - Athènes, le 16 juin 1914", reproduced in Bilâl Şimşir, ed. Ege Sorunu: Belgeler, Vol. II (Ankara: Türk Tarih Kurumu Basimevi, 1982) 518 and 530, at 518 and 530 respectively.

22 A British diplomat wrote that "the movement was a highly-organised one, having for its object to drive out the whole Greek population of the country extending from the south shore of the Marmara to the Cheshme Peninsula, more especially that of the rural districts. The principle of action would appear to have been to effect this object as far as possible by intimidation and without any unnecessary resort to physical violence. This programme was successfully carried out in a large number of the rural districts, with the result that there has been an enormous dislocation of population, attended by only as much ill-treatment as is inseparable from a movement of this nature in view of the ignorance and latent fanaticism of the Moslem population." "Sir L. Mallet to Sir Edward Grey Constantinople, July 5, 1914”, in Şimşir, supra note 21, at 573, 573. Interestingly, some commentators drew parallels with developments elsewhere: "On ne peut pas, en effet, ne pas être frappé par le parallélisme des sentiments et des faits, que présentent les ravages turcs en Asie-Mineure et la brutale agression des Allemands sur la Belgique et le nord-est de la France: c'est la mème fourberie et la mème duplicité diplomatique, le même mépris du droit, le mème cynisme, le mème mélange d'arrogance et de platitude, le mème esprit de destruction à l'égard des antiquités et des œvres d'art." Félix Sartiaux, "Le sac de Phocée et l'expulsion des Grecs ottomans d'Asie-Mineure en juin 1914" 24 (1914) Revue des deux mondes 654 at 655.

23 See, e.g., Kasaba, A Moveable Empire, supra note 12, at 127; Fuat Dündar, Modern Türkiye'nin Şifresi: Ittihat ve Terakkinin Etnisite Mübendisliği (1913-1918) (İstanbul: İletişim, 2008) at 194-216.
} 
War impeding its execution before it ever had a real chance to be tested. Once again, the failure was due not so much to a refusal to abide by pacta sunt servanda as to a factual change rendering the treaty's implementation impossible. ${ }^{24}$ Nonetheless, thousands had by then either fled or been subjected to informal transfer and resettlement, creating a fait accompli which the formal exchange would have streamlined, systematized, and supplied with legal legitimacy. ${ }^{25}$

Though the institutional mechanisms of this exchange were never set in motion, one sees here something akin to "the beginnings of a conscious policy of demographic restructuring and ethnic homogenization", ${ }^{26}$ an undertaking more ambitious than the sort of frontier tinkering that one had with the 1913 exchange between Turkey and Bulgaria. Like this earlier exchange, the 1914 exchange was guided by the recognition that tensions between majority and minority communities in the two states could be managed most effectively if both states took steps to supplement minority protection mechanisms ${ }^{27}$ by diluting the strength of (potential or actual) fifth columns. Indeed, a contemporary student of the transfers of the 1910s has gone so far as to describe that drive to secure ever greater levels of ethno-confessional homogeneity one sees at work on both ends of the Aegean during the 1914 exchange as an internationalized vendetta: here the international legal system's commitment to sovereign equality reveals itself to be little more than a formalized blood feud. ${ }^{28}$ Going beyond the earlier exchange, however, the 1914 exchange foresaw a more professional and autonomous mixed commission - charged as before with coordinating the exchange and with controlling the appraisal, liquidation, and compensation of property, but now equipped with the rudiments of properly bureaucratic organization. This commission was to be comprised of four individuals selected by the two

\footnotetext{
${ }^{24}$ For details, see Ayhan Aktar, "Nüfusun Homojenleştirilmesi ve Ekonominin Türkleştirilmesi Sürecinde Bir Aşama: Türk-Yunan Nüfus Mübadelesi 1923-1924" in Ayhan Aktar, Varlı Vergisi ve "Türkleştirme” Politikalar (İstanbul: İletişim, 2000) 17 at 27; Mustafa Aksakal, The Ottoman Road to War in 1914: The Ottoman Empire and the First World War (Cambridge: Cambridge University Press, 2008) at 43-4.

${ }^{25}$ Yannis G. Mourelos, "The 1914 Persecutions and the First Attempt at an Exchange of Minorities between Greece and Turkey" 26 (1985) Balkan Studies 389 at 404, 410-1.

${ }^{26}$ Mark Levene, “Creating a Modern 'Zone of Genocide': The Impact of Nation- and State-Formation on Eastern Anatolia, 1878-1923” 12 (1998) Holocaust and Genocide Studies 393 at 407.

27 The peace treaty concluded between Greece and Turkey in 1913 had assured a measure of legal autonomy to Muslims in Greece, with matters relating to family law, the law of succession, and the legal status of religious foundations being governed by Shari"a. See Charalambos N. Fragistas, "Le droit musulman en Grèce" 4 (1954) Annales de la Faculté de droit d'Istanbul 129; Samim Akgönül, "Les vestiges du système ottoman dans le traitement des minorités en Grèce et en Turquie" in Sylvie Gangloff, ed., La perception de l'béritage ottoman dans les Balkans (Paris: L'Harmattan, 2005) 43 at 46. Similar guarantees were available to Greeks in Turkey via the millet system and the various minority protection clauses in the multilateral treaties to which the Porte had bound itself.

${ }^{28}$ Dündar, Modern Türkiye'nin Şifresi, supra note 23, at 216-7.
} 
states as well as a "neutral arbiter", appointed, as diplomatic notes exchanged between Athens and Istanbul explained, by "a European state chosen by agreement between the two countries". ${ }^{29}$ While this arbiter "was to take no part in the discussions of the Mixed Commission", he "was to have power to settle finally all differences arising in it". ${ }^{30}$ If the exchange sought to manage majority-minority relations by foregrounding the ethnoconfessional identity of the dominant nation, strengthening its hold over the state's territory and its place within the state's population, the mixed commission was to drive much of this process. Its work would be suspended by the Great War. But the idea of a professionalized body which took the interests of concerned states into account without stripping itself of institutional autonomy was to prove an enticing one for many of the region's statesmen.

Third, one has what was arguably the most important precedent of all, and the first actually to be implemented - the 1919 agreement between Greece and Bulgaria for a full-scale exchange of populations. This was the largest and most ambitious undertaking yet. It did not simply make a systematic and comprehensive (though still voluntary) exchange of populations possible between two rivals, embroiled in a decades-long struggle over Macedonia and Thrace that had spilled over into regular (the Balkan Wars) as well as irregular warfare (bands of komitadji guerrillas launching raids into rural areas on both sides of the border). ${ }^{31}$ It also succeeded in establishing a set of robust institutions for the management of the upheaval. Chief among these was a mixed commission.

The Greek-Bulgarian exchange was governed by a convention signed between the two countries at Neuilly-sur-Seine in 1919 alongside Bulgaria's general peace treaty. Its chief purpose was to pave the way for a smooth "reciprocal emigration" between the two countries, mainly in contested Macedonia and western Thrace, ${ }^{32}$ and it provided a host of mechanisms that

\footnotetext{
29 Stephen P. Ladas, The Exchange of Minorities: Bulgaria, Greece and Turkey (New York: Macmillan, 1932) at 22. The words belong to Ladas, to whom copies of the main notes were made available, rather than to the notes themselves.

30 Ibid.

31 All of this had taken a toll: between 1912 and 1917 alone, the number of Bulgarians and Turks in Macedonia is recorded in some sources as having fallen by approximately 50,000 and 40,000 respectively, with the total number of Greeks increasing by nearly 15,000 in turn. Jordan Ivanoff, Les Bulgares devant le Congrès de la Paix. Documents historiques, ethnographiques et diplomatiques (Berne: Paul Haupt librairie académique, 1919) at 299.

32 Art. 56 of the peace treaty Bulgaria had signed in 1919 stated that Sofia undertook "to recognise such provisions as the Principal Allied and Associated Powers may consider opportune with respect to the reciprocal and voluntary emigration of persons belonging to racial minorities". Treaty of Peace between Belgium, the British Empire, China, Cuba, Czechoslovakia, France, Greece, the Hedjaz, Italy, Japan, Poland, Portugal, the Serb-Croat-Slovene State, Siam and the United States, and Bulgaria, signed at Neuilly-sur-Seine, November 27, 1919, 225 CTS 332 at 344. As
} 
would go on to resurface in the 1923 Greek-Turkish exchange. "The High Contracting Parties recognise", the first article of the convention stated, "the right of those of their subjects who belong to the racial, religious or linguistic minorities to emigrate freely to their respective territories". ${ }^{33}$ In terms that would later be reproduced nearly verbatim in the convention regulating the Greek-Turkish exchange, Article 5 explained that "[e]migrants shall lose the nationality of the country which they leave the moment they quit it and shall acquire that of the country of destination from the moment of their arrival there". ${ }^{44}$ The exchange was to apply to "every person over 18 years of age", and to do so over "a period of two years from the date of constitution of the mixed Commission". ${ }^{35}$ And, as with its predecessors, the bulk of the convention's remaining provisions - Articles 6 through $13^{36}$ - established a regime for transferring movable and liquidating immovable properties that was to be directed by a multinational commission financed by "the Governments concerned". 37

This last point is especially important. Mixed commissions had been called into existence by the 1913 and 1914 agreements. But neither of the two had produced anything on the scale of the commission established for the Greek-Bulgarian exchange. Unlike its predecessors, this was a commission with a veritable army of "agents and instrumentalities" 38 at its disposal; one of the few contemporaneous commentators on the endeavour to have gathered detailed information on the operation records a sizable number of "neutral technical advisers" attached directly to the commission, including an "expert agronomist" and an "expert architect". ${ }^{39}$ These and other officials were stationed in a variety of different locations and affiliated with a variety of different committees and sub-commissions, with the principal nodes of the logistical network that grew out of their interactions being centred in Sofia, Saloniki, and Komotini. It was a complex arrangement, designed to reflect the complexity of the enterprise it was intended to tie together. As the largest and most elaborate venture of its kind, the Greek-

set out in the Convention of Neuilly-sur-Seine's preamble, the population exchange grew out of this provision: Convention between Greece and Bulgaria respecting Reciprocal Emigration, signed at Neuilly-sur-Seine, November 27, 1919, 1 LNTS 67 at 68.

33 Ibid., at 68-9.

34 Ibid., at 69. See also infra Chapter III note 173 and accompanying text.

${ }^{35}$ Convention of Neuilly-sur-Seine, Art. 4, supra note 32, at 69.

36 Ibid., at 69-71.

37 Ibid., Art. 13, at 71

38 The expression is Ladas': supra note 29, at 64.

${ }^{39}$ Ibid. For a breakdown of the liquidations effected by the commission, see André Wurfbain, L'échange gréco-bulgare des minorités ethniques (Lausanne: Librairie Payot \& Cie, 1930) at 212 and part 3 more generally. 
Bulgarian exchange not only demanded a modern machinery of nation-building, but demonstrated - materially and forcefully - the possibility of setting such machinery in motion.

Each of these early experiments - the 1913 exchange between Turkey and Bulgaria, the 1914 exchange between Greece and Turkey, and, finally, the 1919 exchange between Greece and Bulgaria, the first actually to be implemented - played an important role in the development of a corpus of legal precedents in regards to the management of large-scale human movements. But the Greek-Turkish exchange's antecedents do not end here. An exchange had been contemplated in 1919 for Kosovo, then as now claimed by rival factions of (Christian) Serbs and (predominantly Muslim) Albanians. ${ }^{40}$ More importantly, the Treaty of Sèvres - the peace treaty the defeated Ottomans concluded with the Allied Powers after the First World War - called for a population exchange between Greece and Turkey in a brief and generally unnoticed provision. This provision, Article 143, explicitly authorized a voluntary exchange between the two countries: "Within six months from the coming into force of" the treaty, they would "enter into a special arrangement relating to the reciprocal and voluntary emigration of the populations of Turkish and Greek race in the territories transferred to Greece and remaining Turkish respectively". "Sèvres would never enter into force, and the exchange for which it called would never be realized, but the fact that this scheme was considered as seriously as it was points to a growing recognition that it constituted an acceptable, if still exceptional, means of nation-building. If Sèvres was about "la libération d'une grande partie des peuples soumis à la domination turque, comme une suprême intervention d'humanité de l'Europe", ${ }^{2}$ it was also about the crisp partition of a region whose "mixed" character was so widely regarded as unsustainable that even the idea of mandates over a partitioned Ottoman Empire was floated briefly in $1919 .^{43}$

\footnotetext{
40 The proposal would be laid aside as impractical, given the acrimony between the different groups. Margaret MacMillan, Paris 1919: Six Months That Changed the World (New York: Random House, 2003) at 361-2.

${ }^{41}$ Treaty of Peace between the Allied Powers and Turkey, signed at Sèvres on August 10, 1920, 15 (1921) AJIL Sup. 179 at $209-10$.

42 Alexandre Devedji, L'échange obligatoire des minorités grecques et turques en vertu de la convention de Lausanne du 30 janvier 1923 (Paris: Imprimerie du Montparnasse et de Persan-Beaumont, 1929) at 41.

43 Report of the American Section of the International Commission on Mandates in Turkey, reproduced in Papers Relating to the Foreign Relations of the United States: The Paris Peace Conference 1919, Vol. XII (Washington: United States Government Printing Office, 1947) 751. For commentary, see Harry Nicholas Howard, The King-Crane Commission: An American Inquiry in the Middle East (Beirut: Khayats, 1963); Leonard V. Smith, "Wilsonian Sovereignty in the Middle East: The King-Crane Commission Report of 1919" in Douglas Howland and Luise White, eds., The State of Sovereignty: Territories, Laws, Populations (Bloomington: Indiana University Press, 2009) 56. Protestant missionaries
} 
The 1923 endeavour relied on these early experiences in many ways, but it also went beyond them, not least on account of its scope of application and strictly compulsory character. As will be seen in Chapter Three, many of the legal terms by which the earlier transfers and exchanges were governed would find their way into the convention regulating the GreekTurkish exchange. More revealingly still, the similarities between the political and legal rationales advanced in these earlier enterprises and the logic at work behind the Greek-Turkish population exchange are not hard to discern. In the latter case, too, one encounters that peculiar compulsion to "unmix" and "pacify", triggered partly by a series of displacements that has already been instigated, ${ }^{44}$ that can be detected in the experiments of the 1910 s. Here also it was thought necessary to place the requisite authority in the hands of a complex international organization, a third party armed with sufficient savoir faire to stand above the fray and keep watch over the process without siding with one or the other group. Since vulnerable minorities could be shielded from persecution neither through a mandatory programme of systemic reconstruction nor through that unstable combination of domestic legal reform and international treaty obligation which had gained currency in connection with central and eastern Europe after 1919, it was believed that they had to be segregated physically, making it literally impossible - or so, at least, it was hoped - for them to remain embroiled in conflict. In a crucial sense, then, it was only after experience with voluntary exchanges (the earlier exchange between Greece and Bulgaria in particular) revealed that this method of nation-building tended to fall short of its goal of fashioning stable nation-states that recourse was had to a compulsory and fully institutionalized procedure (the Greek-Turkish enterprise itself). ${ }^{45}$ What had formerly been attempted only on a small scale, and even then only with limited resources, was now to be undertaken in a much broader context and as part of a systemic exercise in nation-building.

Far from being a "merely political" sentiment, the idea that curbing ethno-nationalism culminated in population exchange in the Near East was articulated by another innovation of the period - the Permanent Court of International Justice. In an advisory opinion requested by the Council of the League of Nations for the purpose of shedding light on the function and

had pressed for an American mandate even earlier. See especially Hans-Lukas Kieser, Nearest East: American Millennialism and Mission to the Middle East (Philadephia: Temple University Press, 2010) at $93 \mathrm{ff}$.

${ }^{44}$ Cf. Christa Meindersma, "Populations Exchanges: International Law and State Practice - Part 2" 9 (1997) International Journal of Refugee Law 613 at 651.

45 Theodora Dragostinova, "Navigating Nationality in the Emigration of Minorities between Bulgaria and Greece, 1919-1941" 23 (2009) East European Politics 185 at 202, 204. 
authority of the mixed commission that had been established pursuant to the Treaty of Neuillysur-Seine, the World Court held that the 1919 Greek-Bulgarian exchange had been undertaken for one purpose and one purpose only - putting an end to majority-minority conflict. Writing on behalf of the Court, Anzilotti made the point succinctly: "The general purpose of the instrument is thus, by as wide a measure of reciprocal emigration as possible, to eliminate or reduce in the Balkans the centres of irredentist agitation which were shown by the history of the preceding periods to have been so often the cause of lamentable incidents or serious conflicts". "The mixed commission did not command the right "to dissolve a community" as such; but it was entitled "to verify whether dissolution ha[d] taken place, in order then to carry out the measures prescribed in this event by the Convention" ${ }^{47}$ As a result, the key task before it was to determine when the "bonds of solidarity" which constituted a legal "community" came to be "dissolved" by way of emigration. ${ }^{48}$ This would allow it to proceed with liquidation and indemnification efforts on as sound a basis as possible, which, in turn, would further efforts to put the segregation of the two peoples on a firm politico-economic footing.

Of course, the Ottoman Empire did not always view its foreign relations through the prism of ethnicity - or, indeed, even that of faith. Since the early seventeenth century, it had, for instance, been careful to keep its relations with Persia on a non-sectarian, even "secular", basis. As the preeminent Sunni power, with Islam's most sacred cities - and, by extension, rightful title to the caliphate - in its possession, Ottoman Turkey was Shī'a Persia’s natural foe. But from the seventeenth century on, such rivalry had been managed with little regard either to theological divergences or (as became increasingly important in the late nineteenth century) "racial" differences. The Treaty of Zuhab, concluded in 1639 and a basis for most bilateral arrangements between the two empires until their final dissolution in the twentieth century, ${ }^{49}$ bracketed questions of theological affiliation in order to stabilize relations and demarcate the common border. ${ }^{50}$

\footnotetext{
46 The Greco-Bulgarian “Communities”, Advisory Opinion, PCIJ Rep. Series B No. 17 (1930) at 19.

${ }^{47}$ Ibid., at 24 .

48 Ibid., at 25.

${ }^{49}$ Treaty of Peace and Frontiers: The Ottoman Empire and Persia, 17 May 1639, 105 BFSP 763.

50 Maurice Harari, "The Turco-Persian Boundary Question: A Case Study in the Politics of Boundary-Making in the Near and Middle East", Ph.D. dissertation, Columbia University (1958) at 6-7. It was only in the nineteenth century that the ulema, the class of Islamic legal scholars, began to lose some of its traditional influence to its more secular counterparts (though even then most high-ranking imams and müftüs managed to retain some power by ingratiating themselves with governmental authorities). See, e.g., Kemal H. Karpat, "Ifta and Kaza: The Ilmiye State
} 
"Turkey in Europe", on the other hand, was an altogether different matter - an "anomaly", as international lawyers were wont to put it, well into the interwar period. In 1894 Westlake would write that " $[\mathrm{t}]$ he case of Turkey must ... be left out of sight, because of the anomalous position of that empire, included on account of its geographical situation in the political system of Europe, but belonging in other respects rather to the second group of contrasted populations". "She may", he went on, "benefit by European international law so far as it can be extended to her without ignoring plain facts, but her admission to that benefit cannot react on the statement of the law, which is what it is because it is the law of the European peoples." ${ }^{, 51}$ Likewise, the third edition of Lassa Oppenheim's seminal treatise would note that Turkey's "position as a member of the Family of Nations was anomalous, because her civilisation fell short of that of the Western States", explaining that "it was for that reason that the so-called Capitulations were still in force, and that other anomalies still prevailed". ${ }^{2}$ And the sentiments, however crude, were not entirely without basis in the territorial distribution of powers: the Balkans were home to three competing "civilizational blocs" (Slavic-Orthodox, Turkish-Muslim, and Germano-Latin) and at least two broad juridico-political traditions (multinational and neo-Jacobin), intermeshed in complex political and legal arrangements that foreigners often found difficult to untangle. ${ }^{53}$ It should perhaps come as little surprise, then, that an age given to overhauling and reallocating sovereign powers drastically should have resorted to large-scale population movement as an instrument of conflict resolution in this region. As one interwar student of the last phase of the "Eastern Question" wrote, the late Ottoman Empire comprised "an interesting laboratory for the study of the dynamic changes in

and Modernism in Turkey, 1820-1960" in Colin Imber and Keiko Kiyotaki, eds., Frontiers of Ottoman Studies: State, Province, and the West, Vol. I (London: Tauris, 2005) 25 at 28-30. That the Ottomans' relations with the Persians, while clearly coloured by a wide array of political and theological rivalries, remained essentially unaltered by these and other shifts in power in Istanbul testifies to the resilience of the geopolitical order which had been established between the two states in previous centuries.

${ }^{51}$ John Westlake, Chapters on the Principles of International Law (Cambridge: Cambridge University Press, 1894) at 103. This assessment is still mild in comparison with Westlake's account of "uncivilized peoples", capable in his view of achieving European "civilization" only rarely without "the training and discipline which results from European government or control”. John Westlake, "Territorial Sovereignty, Especially with Relation to Uncivilised Regions" in The Collected Papers of John Westlake on Public International Law, ed. Lassa Oppenheim (Cambridge: Cambridge University Press, 1914) 131 at 180.

${ }^{52}$ Lassa Oppenheim, International Law: A Treatise, Vol. I, ed. Ronald F. Roxburgh, 3 ${ }^{\text {rd }}$ Ed. (London: Longmans, 1920) at 34.

${ }^{53}$ For a useful discussion, see Georges Castellan and Alexandre Jevakhoff, "Les Balkans et le Moyen-Orient" in François Boulet, ed., Les traités de paix 1919-1920 et l'Europe au XXème siècle: Versailles, Saint-Germain-en-Laye, Neuillysur-Seine, Trianon, Sèvres (Paris: Les presses franciliennes, 2007) 339 at 340. 
international law", as it was in this, "perhaps better than in any other single area", that one could observe at close hand "the terrific forces which make for international change" ${ }^{54}$ To gain an appreciation of how exactly such "international change" took root, I turn now to the social and political forces at work in the late Ottoman Empire and early Turkish Republic that fed the socio-historical processes through which demographic engineering came into its own as a distinct mode of nation-building.

\section{A Refuge for the Displaced}

Neither the public rationales offered for the various experiments in demographic engineering that preceded the Greek-Turkish exchange nor the actual processes through which they were implemented can be appreciated absent an understanding of the broader social and political context within which they arose. Demographic engineering was not unknown elsewhere. Both White Russians and Bolsheviks, for instance, employed public administrators with technocratic experience to oversee far-reaching land reforms and resettlement programmes in central Asia and Siberia. ${ }^{55}$ It bears noting, though, that these efforts were undertaken with a view to optimizing management of productive resources within a territorially integrated empire. ${ }^{56}$ Indeed, it was in the Near East that the idea of orchestrating large-scale migrations between states (or states-in-the-making) first gained wide circulation as a modern, institutionally buttressed technique of international legal nation-building. Specifically, it was in the hands of the Committee of Union and Progress (İtihat ve Terakki Cemiyeti, known contemporaneously in the West by the broader appellation of "Young Turks" or "Jeunes-Turcs") that population exchange developed into something of a routine mechanism for conflict resolution. The Committee was the Kemalist movement's immediate precursor in power. It was against the background of the ethno-nationalist ideology it cultivated after its rise to power, and the

\footnotetext{
54 Wilbur Wallace White, The Status in International Law of the Fragments of the Ottoman Empire (Chicago: University of Chicago Press, 1938) at 331.

55 Peter Holquist, "In Accord with State Interests and the People's Wishes': The Technocratic Ideology of Imperial Russia’s Resettlement Administration” 69 (2010) Slavic Review 151. For further illustrations, see István Deák, "How to Construct a Productive, Disciplined, Monoethnic Society: The Dilemma of East Central European Governments, 1914-1956" in Amir Weiner, ed., Landscaping the Human Garden: Twentieth-Century Population Management in a Comparative Framework (Stanford: Stanford University Press, 2003) 205.

56 One official involved in the restructuring of land holdings in Russian Siberia referred to this as a "good technology for ruling". Holquist, supra note 55, at 179.
} 
centralized techniques of administration to which it had recourse in an effort to keep the Ottoman Empire from disintegrating beneath the centrifugal pressures of secessionist nationalism and great power intrigue, that notions of population exchange began to gain popularity.

Though the Committee was officially committed to a vision of common Ottoman citizenship whose roots reached back to the mid-nineteenth century, ${ }^{57}$ and though its ranks initially included many non-Turks, it grew decreasingly reluctant after 1908-9 to advance policies designed to strengthen the Turkish-Muslim "core" of Ottoman state and society (the Ottoman Empire's Muslims had long been characterized as the millet-i hâkime, or "ruling nation"). Over the course of 1908 and 1909, it deposed the reigning sultan, curtailed his successor's powers, and inaugurated a period of quasi-parliamentary rule by restoring and revising the 1876 Ottoman constitution after nearly three decades of suspension. ${ }^{58}$ Thenceforth numerous attempts were made to tighten Istanbul's grip over the provinces through a series of ham-fisted modernization and state-centralization initiatives: the prioritization of Turkish in courts and schools, curtailment of freedom of association and freedom of the press, augmentation of the authority of provincial governors, establishment of well-organized police, gendarme, and security services, provision of sweeping constitutional powers for the institution of martial law and conduct of counter-insurgency operations, strategic use of militias and paramilitaries to tackle Armenian, Albanian, and eventually Arab insurgencies, and, after the outbreak of total war in 1914, the genocidal deportation and massacre of Anatolia's Armenian population. ${ }^{59}$ Materially, these moves were designed to "save the state" (devleti kurtarmak) by

\footnotetext{
${ }^{57}$ References to the "Jeune Turquie" began appearing in print at least as early as 1855, at a time when reformists of various stripes (most known colloquially as the "new" or "young" Ottomans) started rallying around Westerninspired programmes of modernization. Most such programmes had as their central goal the development of a pan-Ottoman basis for imperial revival. Şerif Mardin, The Genesis of Young Ottoman Thought: A Study in the Modernization of Turkish Political Ideas (Princeton: Princeton University Press, 1962) at 40. Mardin dates the first usage of "Young Turk" even earlier, to 1829. Ibid., at 41, fn.

${ }^{58}$ For a detailed account of the supplanting of the ancien régime, see Aykut Kansu, The Revolution of 1908 in Turkey (Leiden: Brill, 1997), ch. 4. The tension between the Committee's formal commitment to Ottomanism and its increasingly strident vision of Turkish nationalism is sometimes presented as the product of a split within the Young Turk movement, with the Committee being the nationalist driving force behind a larger, less well-defined movement which also included liberals and other advocates of minority rights. For a classic articulation, see Bernard Lewis, The Emergence of Modern Turkey, $3^{\text {rd }}$ Ed. (Oxford: Oxford University Press, 2002) at $213 \mathrm{ff}$.

${ }^{59}$ For discussion of most of these measures, see Stanford J. Shaw and Ezel Kural Shaw, History of the Ottoman Empire and Modern Turkey, Vol. II (Cambridge: Cambridge University Press, 1977) at 285-8, 306-10. For sources on the Armenian genocide, on which Shaw and Shaw are notably reticent, see supra Introduction note 54, and also the discussion in Chapter IV.
} 
stifling opposition wherever local landowning elites were able to contest Istanbul's authority ${ }^{60}$ and by cultivating an indigenous Turkish-Muslim commercial class that could reverse comprador-facilitated economic intervention. ${ }^{61}$ Ideologically, they reflected Istanbul's desire to deflect European charges of "fanaticism" and "backwardness". As the Ottoman state was widely (if somewhat mistakenly) viewed as anachronistic, falling short of modern Western standards of statehood, it was only by attenuating existing structures of pluralism that the Committee believed it stood a chance of "catching up" to "contemporary civilization". ${ }^{2}$

The result of these developments was an acute case of heightened centre-periphery tensions. ${ }^{63}$ Complete with ever more trenchant forms of nationalism in Armenian, Albanian, and Arab provinces, and progressively violent reactions from the Porte, including mass-scale forced migration and, most catastrophically, genocide, the Committee of Union and Progress' heavy-handed drive toward centralization often backfired, engendering more ressentiment than it did solidarité. Administrative consolidation in the name of "national sovereignty" (the expression seems to have entered Turkish - as hakimiyet-i milliye - for the first time through the Committee's publications ${ }^{64}$ ) was frequently resisted, particularly when accompanied, as it often was, by efforts to strengthen Turkish or Muslim groups at the expense of their non-Turkish or non-Muslim counterparts. In fact, the Committee's policies often retrenched precisely those insurgent nationalisms they were meant to suppress: far from being passive recipients of yet another wave of modernization iniatives imposed from above, non-Muslim provincial notables in many provinces regularly turned governmental innovations to their benefit, using them to

\footnotetext{
${ }^{60}$ It should be noted, though, that these moves were not wholly unprecedented. A key piece of reform legislation enacted in 1864 with a view to bringing Arab sheikhs and other tribal authorities within the jurisdiction of newly established courts does not seem to have engendered significant resistance even among otherwise disgruntled Arab elites. Keiko Kiyotaki, "The Implementation of the Administrative Law of 1864 in the Province of Baghdad" in Markus Köhbach, Gisela Prochházka-eisl, and Claudia Römer, eds., Acta Viennensia Ottomanica. Akten des 13. CIEPO - Symposiums vom 21. bis 25. September 1998 in Wien (Wien: Selbstverlag des Instituts für Orientalistik, 1999) 215.

${ }^{61}$ Tark Zafer Tunaya, Türkiye'de Siyasal Partiler, Vol. III, $2^{\text {nd }}$ Ed. (İstanbul: Hürriyet Vakf1 Yayınlar1, 1989) at 34368. The belief that the Empire's non-Muslims had exploited their dominance over European trade, often by lending financial and logistical support to insurrectionary organizations, had been widespread among Ottoman revivalists and Turkish nationalists for decades already. For the macro-level dynamics, see generally Fatma Müge Göçek, Rise of the Bourgeoisie, Demise of Empire: Ottoman Westernization and Social Change (Oxford: Oxford University Press, 1996).

${ }^{62}$ This often involved attempts to orientalize the Empire's Arabs, Kurds, and other non-Turkish Muslims. Ussama Makdisi, “Ottoman Orientalism” 107 (2002) American Historical Review 768, esp. at 795.

${ }^{63}$ M. Şükrü Hanioğlu, A Brief History of the Late Ottoman Empire (Princeton: Princeton University Press, 2008) at 167 ff. See further Şerif Mardin, “Center-Periphery Relations: A Key to Turkish Politics?” 102 (1973) Daedalus 169, esp. at $181,187$.

${ }^{64}$ Hanioğlu, supra note 63, at 165.
} 
augment social and legal structures derived from the millet system so as to bolster fragile or incipient national identities. ${ }^{65}$ The Committee's official reliance on Ottomanism as an overarching point of reference for the Empire's citizenry went some way to temper such peripheral movements, particularly in Arab provinces, where secessionism does not appear to have emerged as a genuinely serious source of political mobilization until the mid-1910s. ${ }^{66}$ Yet, undergirding this public commitment was a dedication to the increasing Turkification of the Empire's economy and society. Such ethno-nationalism inspired most of the Committee's policies in regards to engineered population movements. ${ }^{67}$

The stance adopted by the Committee of Union and Progress with respect to the galvanization of the Empire's Turkish-Muslim "core" was closely associated with an awareness of the social consequences that had attended the Ottoman Empire's numerous territorial losses. Some of these losses had been due to large-scale rebellions in the provinces, often fuelled, or at least fanned, by European powers. Others, such as the loss of Tripolitania and other provinces (forming present-day Libya) to Italy in 1912, stemmed from full-blown war, frequently with these same powers. A point of particular sensitivity was the mass displacement of Balkan

65 See, e.g., Yonca Köksal, "Rethinking Nationalism: State Projects and Community Networks in 19th_Century Ottoman Empire" 51 (2008) American Behavioral Scientist 1498 at 1509-10. Note that this was not a new development. For the view that Bulgarian notables' engagement with Tanzimat-era administrative councils and financial institutions was key to the production of new modes of governance, see M. Safa Saraçoğlu, "Some Aspects of Ottoman Governmentality at the Local Level: The Judicio-Administrative Sphere of the Vidin County in the 1860s and 1870s" 9 (2008) Ab Imperio 223. For an argument that such processes struck even deeper into everyday life, with "ordinary" men and women and men in the vilayet of the Danube (Tuna) playing critical roles in the Tanzimat's operationalization, see Milen V. Petrov, "Everyday Forms of Compliance: Subaltern Commentaries on Ottoman Reform, 1864-1868” 46 (2004) Comparative Studies in Society and History 730.

${ }^{66}$ C. Ernest Dawn, "The Rise of Arabism in Syria" in C. Ernest Dawn, From Ottomanism to Arabism: Essays on the Origins of Arab Nationalism (Urbana, IL: University of Illinois Press, 1973) 148 at 152-4; C. Ernest Dawn, "The Quality of Arab Nationalism" in Derek Hopwood, ed., Arab Nation, Arab Nationalism (Houndsmills: Macmillan, 2000) 41 at 44; Hasan Kayal1, Arabs and Young Turks: Ottomanism, Arabism, and Islamism in the Ottoman Empire, 19081918 (Berkeley: University of California Press, 1997) at 12-3; Adeed Dawisha, Arab Nationalism in the Twentieth Century: From Triumph to Despair (Princeton: Princeton University Press, 2003) at 33, ch. 2 generally. Even those accounts of Arabism's growth which attempt to demonstrate its influence before 1914 tend to concede that it did not generate calls for independence until the First World War was well underway: see, e.g., Rashid Khalidi, "Ottomanism and Arabism in Syria Before 1914: A Reassessment" in Rashid Khalidi et al., ed., The Origins of Arab Nationalism (New York: Columbia University Press, 1991) 50. The most notable exception is, of course, Egypt, formally bound to Istanbul until the Empire's dissolution but effectively autonomous or under European administration after Muhammad Ali. See generally Afaf Lutfi al-Sayyid Marsot, Egypt in the Reign of Mubammad Ali (Cambridge: Cambridge University Press, 1984); Khaled Fahmy, All the Pasha's Men: Mehmed Ali, His Army and the Making of Modern Egypt (Cambridge: Cambridge University Press, 1997).

${ }^{67}$ For admirable lucidity, see Nesim Şeker, "Demographic Engineering in the Late Ottoman Empire and the Armenians" 43 (2007) Middle Eastern Studies 461 at 464. An unpersuasive recital of the opposing argument can be found in Erol Ülker, "Contextualising 'Turkification': Nation-Building in the Late Ottoman Empire, 1908-18” 11 (2005) Nations and Nationalism 613. 
Muslims to which a succession of Ottoman military defeats had given rise. Large migrations of Muslims from the Balkans had occurred more or less without pause since the late 1860s. Due largely to Russian-Ottoman rivalry in the Balkans and Caucasus and a series of related conflicts with Serbian, Bulgarian, and Greek forces, these movements were sometimes generated or legitimated by bilateral agreements. ${ }^{68}$ Roughly 20,000 Tatars from Russia are reported to have been settled in the Ottoman Empire in the 1860s. ${ }^{69}$ And nearly 850,000 Muslims appear to have entered the Ottoman Empire as refugees between 1876 and 1896, with no less than 276,389 recorded in 1876 alone. $^{70}$ Whereas in 1820 an estimated 60\% of the Ottoman Empire's citizens had been Muslim, by 1914 the same statistic had climbed to 80\%. ${ }^{71}$ Not surprisingly, these migrations had focused the energies of large chunks of the Ottoman state's Turkish-Muslim citizenry around new or hitherto marginal causes, contributing to the popularization of Turkish nationalism (and, in some cases, pan-Turkism) as a counterweight to Ottomanism and Islamism, the two other "routes to modernity" generally regarded as viable and available at the time. $^{72}$ But while highly significant in their cultural and ideological after-effects, ${ }^{73}$ none of these movements seems to have reconfigured the Turkish socio-political imaginary quite as radically and systematically as the events of the 1910s would. It was only with the Balkan Wars and the First World War that such a reconfiguration would occur, the ensuing en masse displacement of Muslims - perhaps as much as 400,000 between 1912 and $1920,{ }^{74}$ or over $60 \%$ of the Balkan

\footnotetext{
${ }^{68}$ For details, see Kemal Karpat, Ottoman Population, 1830-1914: Demographic and Social Characteristics (Madison: University of Wisconsin Press, 1985) at 60-77. For the causes of emigration from the Balkans, see Alexandre Toumarkine, Les migrations des populations musulmanes balkaniques en Anatolie (1876-1913) (İstanbul: Les éditions Isis, 1995) at 39-67.

${ }^{69}$ Brian Glyn Williams, "Hijra and Forced Migration from Nineteenth-Century Russia to the Ottoman Empire: A Critical Analysis of the Great Crimean Tatar Emigration of 1860-1861" 41 (2000) Cabiers du monde russe 79.

70 Stanford J. Shaw, "Ottoman Population Movements during the Last Years of the Empire, 1885-1914: Some Preliminary Remarks” 1 (1980) Osmanl Arasttrmalar 191 at 193.

${ }^{71}$ Michael Mann, The Dark Side of Democracy: Explaining Ethnic Cleansing (Cambridge: Cambridge University Press, 2005) at 114.

${ }^{72}$ Feroz Ahmad, The Young Turks: The Committee of Union and Progress in Turkish Politics, 1908-1914 (Oxford: Clarendon Press, 1969) at 154-5. Ottoman political theorists of the turn of the twentieth century often viewed these as the three main modes of ideological mobilization. For the locus classicus, see Yusuf Akçura, Ü̧ Tarž-ı Siyaset (Ankara: Türk Tarih Kurumu, 1976 [1904]). For an influential, though dated, gloss, see Niyazi Berkes, The Development of Secularism in Turkey (Montreal: McGill University Press, 1964) at 337-46, 359-66.

${ }^{73}$ Refugees from Russia soon came to establish themselves as leading voices in the emergent Turkish-Muslim intelligentsia; for a suggestive overview, see Howard Eissenstat, "Turkic Immigrants / Turkish Nationalism: Opportunities and Limitations of a Nationalism in Exile" 25/26 (2003) Turkish Studies Association Bulletin 25.

${ }^{74}$ McCarthy, supra note 10, at 161.
} 
Muslim population from 1912 to $1923^{75}$ - playing a key role in the growth of Turkish revanchism. $^{76}$

The conviction that Asia Minor served as a kind of "sanctuary" for displaced Turks and Muslims was quite common among those forced to abandon their homes in the Balkans during the final years of Ottoman rule. This, it was widely assumed, was the one territory upon which Turkish nationalism should - and, from a properly tactical standpoint, could - concentrate the full force of its energies with a view to mounting a "regeneration" of the "Turkish nation". Directly or indirectly driven from the Balkans, ${ }^{77}$ economically the Empire's most dynamic region and the one which generally supplied it with the greatest number of civilian personnel, the Committee of Union and Progress' leading figures sought to restructure Anatolia, viewed both as the foundation and as the future of the "Turkish nation", their chief point of ideological allegiance, in accordance with the cultural and political requirements of an idealized "Turkish homeland", ${ }^{78}$ Demographic engineering was, in fact, so crucial a part of the Committee's policies that provincial and district-level civil servants were sometimes instructed to prepare detailed ethnographic maps and statistical tables, down to even the most isolated villages. ${ }^{79}$ The settlement of Turks and Muslims in strategically sensitive portions of Anatolia and eastern Thrace was only one facet of a broader programme of Turkification in which not only non-

${ }^{75}$ Dominic Lieven, "Dilemmas of Empire 1850-1918. Power, Territory, Identity" 34 (1999) Journal of Contemporary History 163 at 168.

${ }^{76}$ Fikret Adanır and Hilmar Kaiser, "Migration, Deportation, and Nation-Building: The Case of the Ottoman Empire" in René Leboutte, ed., Migrations et migrants dans une perspective historique: permanences et innovations (Brussels: P. I. E. - Peter Lang, 2000) 273 at 279-80; Çağlar Keyder, "Bir Türk Milliyetçilik Tarihi ve Coğrafyası" in Çağlar Keyder, Memâlike-i Osmaniye'den Avrupa Birliǚ'ne (İstanbul: İletişim, 2003) 73 at 77-9.

77 By the time the Balkan Wars broke out in 1912, migrations and territorial changes had so modified the demographic composition of the Balkans that only Albania seems to have had a majority Muslim population. Kemal H. Karpat, "The Muslim Minority in the Balkans" in Kemal H. Karpat, Studies on Turkish Politics and Society: Selected Articles and Essays (Leiden: Brill, 2004) 523 at 529.

${ }^{78}$ See, e.g., Dündar, Müsliumanlar İskân Politikası, supra note 11, at 36-8.

${ }^{79}$ Fuat Dündar, "The Settlement Policy of the Committee of Union and Progress 1913-1918" in Hans-Lukas Kieser, ed., Turkey Beyond Nationalism: Towards Post-Nationalist Identities (New York: Tauris, 2006) 37 at 39. Interestingly, the sultans' decision in the nineteenth century to import German and French methods of compiling statistics had been one of the factors in the production of a Westernized Ottoman bureaucracy: see Fatma Müge Göçek and M. Şükrü Hanioğlu, "Western Knowledge, Imperial Control, and the Use of Statistics in the Ottoman Empire" in Jayne L. Warner, ed., Cultural Horizons: A Festscbrift in Honor of Talat S. Halman (Syracuse: Syracuse University Press / Yap1 Kredi Yayınlar1, 2001) 105 at 111; Kemal H. Karpat, "The Ottoman Adoption of Statistics from the West in the $19^{\text {th }}$ Century" in Kemal H. Karpat, Studies on Ottoman Social and Political History: Selected Articles and Essays (Leiden: Brill, 2002) 132, esp. at 136-40. 
Muslim but Muslim groups such as Kurds, Arabs, Bosnians, Albanians, Circassians, and others were shuffled from one region to another in the name of national security. ${ }^{80}$

These tendencies only grew stronger in response to the Allied Powers' attempted dismemberment of the Ottoman Empire in line with the 1916 Sykes-Picot Agreement, ${ }^{81}$ and the subsequent British-backed Greek invasion of western Anatolia in 1919, ${ }^{82}$ which the Turkish national movement succeeded in countering with substantial Soviet support in arms and capital. $^{83}$ Many of the Committee's highest ranking officials would quickly come to form the bedrock of the Ankara-based nationalist movement, comprising the bulk of the leadership of Mustafa Kemal's "National Forces" (Kuva-i Milliye). The very terms of the movement's "National Pact" (Misak-1 Millî) made it clear that Anatolia would constitute the geographical core of the new, post-Ottoman Turkish state, Kemal and his followers pledging to continue the war until such time as their position on this matter had secured international recognition. ${ }^{84}$ The displacement and settlement policies of the Committee had redistributed communities in Asia Minor and the Balkans so "efficiently" that Kemal's nationalist movement inherited an Anatolia more thoroughly Turkish-Muslim - and therefore more likely to submit to total mobilization as part of an anti-imperialist resistance movement - than at any earlier time. ${ }^{85}$ All that was necessary was to tap into the frustrations and aspirations of this multitude so as to concentrate it around a common programme of national struggle. In the war's aftermath, after the expected military victory, the Committee's appetite for demographic engineering would be brought to bear upon the last and arguably most recalcitrant non-Muslim minority of all - the Greek minority. Thus, as Zürcher puts it, “[t]he feeling that Anatolia was the 'Turk's last stand', the

\footnotetext{
${ }^{80}$ Dündar, "Settlement", supra note 79, at 41-2.

${ }^{81}$ Exchange of Letters between France and Great Britain respecting the Recognition and Protection of an Arab State in Syria, 9 May 1916, 221 CTS 323.

82 Britain's complicity in the invasion was anything but tangential. See, e.g., Abe Attrep, “'A State of Wretchedness and Impotence': A British View of Istanbul and Turkey, 1919" 9 (1978) International Journal of Middle East Studies 1; Erik Goldstein, “Great Britain and Greater Greece, 1917-1920” 32 (1989) Historical Journal 339.

83 The relationship was not merely one of "assistance": between 1921 and 1923, at the height of the Greek-Turkish War, trade with Turkey appears to have comprised something on the order of a full quarter of Bolshevik Russia's Asian trade. Violet Conolly, Soviet Economic Policy in the East: Turkey, Persia, Afghanistan, Mongolia and Tana Tuva, Sin Kiang (London: Oxford University Press, 1933) at 36. See further Stefanos Yerasimos, Türk-Soryet Iliskileri: Ekim Devriminden "Milli Mücadele"ye (İstanbul: Gözlem, 1979); Bülent Gökay, A Clash of Empires: Turkey between Russian Bolshevism and British Imperialism, 1918-1923 (London: Tauris, 1997).

${ }^{84}$ See the text of the "National Pact", as reproduced in Arnold J. Toynbee, The Western Question in Greece and Turkey: A Study in the Contact of Civilisations, 2nd Ed. (London: Constable and Co. Ltd., 1923) at 209. For the Turkish original, see Reşad Ekrem Koçu, Osmanl Muahedeleri, Kapitülasyonlar, 1300-1920, ve Lozan Muahedesi, 24 Temmuz 1923 (İstanbul: Muallim Ahmet Halit Kitaphanesi, 1934) at 267-8.

85 Dündar, "Settlement", supra note 79 , at 42.
} 
homeland that had to be secured at all cost, directly led to the attempts of the Young Turks and their Kemalist successors to homogenize the population of Anatolia and to turn it into a land for Turks only". ${ }^{86}$

The precise extent to which the policies put in place by the Committee of Union and Progress' intelligentsia can be linked to the administrative mechanisms favoured by the Kemalist movement are open to debate. Yet the implications of Zürcher's central insight - that the one was in many ways organically linked with the other - lend themselves to generalization without much difficulty. The overwhelming majority of those comprising the core of the Kemalist national movement, responsible for every reform of any consequence during the first three decades of the Turkish Republic's history, shared a common social background, virtually identical educational credentials, a strikingly analogous set of political commitments, and a similar willingness to track, and in many cases simply import, the cultural, administrative, and technological innovations of the West. The commonalities would be downright astonishing, in fact, were they not amenable to empirical verification:

"What we are left with is a group of 37 persons with a very clear and coherent profile. A generation of men, born in the 1880s in Muslim families in an urban environment in Southeastern Europe and in the coastal areas of the Marmara and the Aegean; people, formed in the colleges, which the Ottoman Empire had established after European models in the nineteenth century, who knew at least one European language and who went on to professional careers in the service." ${ }^{, 7}$

Save for the Ottoman noblesse d'épée, significantly delegitimized by a series of humiliating military defeats and obvious economic dependence on the West, this ambitious generation - in many ways a classic illustration of an upwardly mobile patriotic group fixated on nationalist renewal $^{88}$ - had little standing in the way of its seizing power, which it did first with the Young Turks' palace revolution in 1908 and then with Kemal's nationalist movement in Anatolia. Of course, neither its provenance in nor its experience of expulsion from the Balkans is capable of

\footnotetext{
${ }^{86}$ Erik Jan Zürcher, "How Europeans Adopted Anatolia and Created Turkey" 13 (2005) European Review 379 at 388.

${ }^{87}$ Ibid., at 385. See also Erik-Jan Zürcher, “The Young Turks: Children of the Borderlands?” 9 (2003) International Journal of Turkish Studies 275 at $279-82$.

88 And, in this very broad sense, not terribly different from similar groups in central and eastern Europe. See, e.g., Miroslav Hroch, "From National Movement to the Fully-formed Nation: The Nation-building Process in Europe" in Gopal Balakrishnan, ed., Mapping the Nation (London: Verso, 1996) 78 at 85-6.
} 
accounting fully for the developmental trajectory of the early Turkish Republic, at least not when considered in isolation. Still, that the bulk of those responsible for the consolidation of the Kemalist nation-state shared a background displaying such extraordinary uniformity is neither accidental nor unimportant. The loss of the Empire's wealthiest, most thoroughly Westernized, and socio-economically least feudal provinces was a matter of extreme urgency, and one that was to have lasting consequences for the homogenization policies to which the Kemalists, like the Committee of Union and Progress before them, ${ }^{89}$ committed themselves.

It is a matter of some importance that this prioritization of ethnic homogenization owed much to the writings of European intellectuals sympathetic to economic nationalization. ${ }^{90}$ Friedrich List, theorist of the aptly termed "national system" of economics, nineteenth-century British free trade doctrine's protectionist rival, ${ }^{11}$ was a mainstay here, supplementing the reception of largely French positivist literature on social engineering. ${ }^{92}$ But far and away the most influential - and illuminating - figure was Alexander Israel Helphand, the Second International theoretician, revolutionary, arms dealer, and spy widely credited with having facilitated Lenin's re-entry into Russia in 1917 and with having formulated the theory of the permanent revolution that would later be picked up and developed by Trotsky. ${ }^{93}$ According to Helphand, a resident of Istanbul and close advisor to the Committee's inner circle in the 1910 s, ${ }^{94}$ the Ottoman state had no choice but to abrogate the capitulations, do away with the Public Debt Organization (Düyun-1 Umumiye) formed by British and French financiers to absorb government revenue through tax collection after the Empire's effective bankruptcy in

\footnotetext{
${ }^{89}$ Erik Jan Zürcher, The Unionist Factor: The Rôle of the Committee of Union and Progress in the Turkish National Movement, 1905-1926 (Leiden: Brill, 1984), chs. 3, 4; Erik Jan Zürcher, “The Ottoman Legacy of the Turkish Republic: An Attempt at a New Periodization” 32 (1992) Die Welt des Islams 237 at 247.

90 Zafer Toprak, Türkiye'de "Milli İktisat” (1908-1918) (İstanbul: Yurt Yayınlar1, 1982) at 25-35.

91 Eric Hobsbawm, Nations and Nationalism since 1780: Programme, Myth, Reality, 2nd Ed. (Cambridge: Cambridge University Press, 1992) at 29-31. For the conditions that made such protectionism attractive to German elites, see Giovanni Arrighi, The Long Twentieth Century: Money, Power, and the Origins of Our Times (London: Verso, 1994) at 61-2. 92 Şevket Pamuk, "The Ottoman Economy in World War I" in Stephen Broadberry and Mark Harrison, eds., The Economics of World War I (Cambridge: Cambridge University Press, 2005) 112 at 119. See further Donald Quataert, "The Age of Reforms, 1812-1914" in Halil İnalc1k and Donald Quataert, eds., An Economic and Social History of the Ottoman Empire, Vol. II (Cambridge: Cambridge University Press, 1994) 759 at 763-5; Roman Szporluk, Communism and Nationalism: Karl Marx versus Friedrich List (Oxford: Oxford University Press, 1988) at 228-9.

${ }^{3}$ Heinz Schurer, "Alexander Helphand-Parvus - Russian Revolutionary and German Patriot” 18 (1959) Russian Review 313 at $318,326$.

94 Z. A. B. Zeman and W. B. Scharlau, The Merchant of Revolution: The Life of Alexander Israel Helphand (Parvus) $1867-$ 1918 (London: Oxford University Press, 1965), ch. 6.
} 
the $1870 \mathrm{~s},{ }^{95}$ and ensure that a thoroughly "native" (i.e. Turkish-Muslim) bourgeoisie, sovereign over capital accumulation and equipped to resist European imperialism, was gradually built. ${ }^{96}$ Should formal transfers and exchanges of Ottoman subjects prove necessary for the achievement of these objectives, then this too would have to be countenanced.

Differences notwithstanding, both the Committee and the Kemalists would take proposals of the kind that Helphand offered to heart, with the latter making use of the GreekTurkish exchange to deepen and expand the anti-liberal economic policies launched by the former in the 1910s (Kemal himself would declare in 1936 that the Turkish revolution had always been developed in accordance with "a system other than "liberalism" ${ }^{97}$ ). Once approximately one sixth of the total land in western Anatolia that could be cultivated had been vacated, ${ }^{98}$ and the proportion of Christians had dropped from one in five citizens (in 1913) to one in forty (in 1923), ${ }^{99}$ it was no difficult business for the Kemalists to press ahead with the Committee's plan to institute a new property regime favouring a thoroughly "indigenous" Turkish bourgeoisie. Indeed, "land reform" of this sort was key to the development of such a bourgeoisie, as approximately $80 \%$ of ethnic Turks inhabiting the early Republic belonged to the peasantry. ${ }^{100}$

That the Greek-Turkish exchange had been instigated in part by Greece's determination during the Greek-Turkish War to achieve the "Great Idea" (Megali Idea) of an enlarged Hellenic

95 Donald C. Blaisdell, European Financial Control in the Ottoman Empire: A Study of the Establishment, Activities, and Significance of the Administration of the Ottoman Public Debt (New York: Columbia University Press, 1929); Herbert Feis, Europe the World's Banker 1870-1914: An Account of European Foreign Investment and the Connection of World Finance with Diplomacy before the War (New York: Augustus M. Kelley, 1930) at 332-41; Roger Owen, The Middle East in the World Economy 1800-1914 (London: Methuen, 1981) at 191-200.

96 M. Asim Karaömerlioğlu, "Helphand-Parvus and His Impact on Turkish Intellectual Life" 40 (2004) Middle Eastern Studies 145, esp. at 152-3. Such assessments were comparatively novel for the Young Turks, whose grasp of political economy tended to be rather shaky. Çağlar Keyder, "The Ottoman Empire" in Karen Barkey and Mark von Hagen, eds., After Empire: Multiethnic Societies and Nation-Building - The Soviet Union and the Russian, Ottoman, and Habsburg Empires (Boulder: Westview Press, 1997) 30 at 37; Yavuz Selim Karak1şla, "The Emergence of the Ottoman Industrial Working Class, 1839-1923" in Donald Quataert and Erik Jan Zürcher, eds., Workers and the Working Class in the Ottoman Empire and the Turkish Republic 1839-1950 (London: Tauris, 1995) 19 at 32.

97 Quoted in Donald E. Webster, "State Control of Social Change in Republican Turkey" 4 (1939) American Sociological Review 247 at 247. For Kemal's most influential statement of economic policy, see Mustafa Kemal, "Gazi Mustafa Kemal Paşa Hazretlerinin İlk Türkiye İktisat Kongresindeki İftitahī Nutukları” in A. Afetinan, ed., İzmir İktisat Kongresi (17 Şubat-4 Mart 1923) (Ankara: Türk Tarih Kurumu Basımevi, 1989) 57.

98 Çağlar Keyder, The Definition of a Peripheral Economy: Turkey 1923-1929 (Cambridge: Cambridge University Press / Éditions de la maison des sciences de l'homme, 1981) at 23.

${ }^{99}$ Çăglar Keyder, "The Consequences of the Exchange of Populations for Turkey” in Renée Hirschon, ed., Crossing the Aegean: An Appraisal of the 1923 Compulsory Population Exchange between Greece and Turkey (New York: Berghahn, 2003) 39 at 43.

100 Gülten Kazgan, "Millî Türk Devletinin Kuruluşu ve Göçler" 30 (1970-1) İstanbul Üniversitesi İktisat Fakeültesi Mecmuast 311 at 323. 
state - a guiding principle of its foreign policy often defended by Greek international lawyers ${ }^{101}$ and widely seen as foundational to its claim to modernity ${ }^{102}$ - played a significant role here as well. Of all the non-Muslim millets, it had arguably been the Greeks who had benefited most visibly from the Ottoman Empire's incorporation into the European world economy from the late eighteenth century onwards, being engaged in international trade, tax farming, money lending, and a variety of other activities. ${ }^{103}$ Increasingly powerful Western corporations, employing Istanbul as a regional marketing and distribution centre, had long preferred to work with local Greeks rather than with the comparatively few Muslim entrepreneurs who were on hand. ${ }^{104}$ During and after the Great War, politically and commercially active elements of the Greek millet saw an opportunity to realize the Megali Idea, with Venizelos himself calling for "the creation of a great and powerful Greece, constituting not an extension of the State by conquest, but a natural return to the limits within which Hellenism has flourished ever since the prehistoric period". ${ }^{105}$ Predictably, they also bore the brunt of the Turkish-Muslim elite's xenophobic reaction when it came to feel that it had its proverbial back against the wall. The bulk of those transferred to Greece were urban, literate, and commercially dynamic; they were generally in command of a broad array of professional skills, armed with substantial experience in lucrative trades and industries, and in possession of a high degree of cosmopolitan social

101 To take but one example, Neoklis Kazazis of the University of Athens argued that every state is entitled to pursue the goal of national integration "as long as it does not violate the sovereign rights of neighbouring states". Quoted in Anastasia Stouraiti and Alexander Kazamias, "The Imaginary Topographies of the Megali Idea: National Territory as Utopia” in P. Nikiforos Diamandouros, Thalia Dragonas, and Çağlar Keyder, eds., Spatial Conceptions of the Nation: Modernizing Geographies in Greece and Turkey (London: Tauris, 2010) 11 at 19.

102 See, e.g., Richard Clogg, A Concise History of Greece, $2^{\text {nd }}$ Ed. (Cambridge: Cambridge University Press, 1992), ch. 3.

103 It remains somewhat unclear, however, what the precise causal relations were, i.e. whether Ottoman Greeks owed most of their politico-economic power to collaboration with European states, or whether these states instead chose to employ them as intermediaries because they were already positioned to do so. Reşat Kasaba, "A Time and a Place for the Nonstate: Social Change in the Ottoman Empire during the "Long Nineteenth Century" in Joel S. Migdal, Atul Kohli, and Vivienne Shue, eds., State Power and Social Forces: Domination and Transformation in the Third World (Cambridge: Cambridge University Press, 1994) 207 at 213. For arguments to the effect that, in many cases, Ottoman Greeks did not facilitate but instead resisted the Empire's penetration by Western capital in the midnineteenth century, viewing foreigners as competitors rather than collaborators, see also Reşat Kasaba, The Ottoman Empire and the World Economy: The Nineteenth Century (Albany: State University of New York Press, 1989) at 58-60, 75-83, 85; and also Reşat Kasaba, "Was There a Compradore Bourgeoisie in Mid-Nineteenth-Century Western Anatolia?" 11 (1988) Review 215.

104 See, e.g., Yavuz Koese, "Nestlé in the Ottoman Empire: Global Marketing with Local Flavour 1870-1927” 9 (2008) Enterprise and Society 724 at 733, 742.

105 "The Proposed Extermination of the Hellenic Race in Asia Minor" in Eleutherios Venizelos, Greece in Her True Light: Her Position in the World-Wide War as Expounded by El. K. Venizelos (New York: n.p., 1916) 183 at 191. 
capital. ${ }^{106}$ By contrast, the majority of those who found themselves in Turkey were farmers and tradespersons from Macedonia and western Thrace, areas that had been neglected in Athens' effort to expand its sphere of socio-economic influence in the late nineteenth and early twentieth centuries. ${ }^{107}$

Not without justification, then, some have argued that since " $[t]$ he policy of creating a 'national economy,' which the Kemalist regime inherited from the Young Turk regime, meant the transfer of the economic position of the Christian minority to the Turkish-Muslim majority", the economic division between Muslim and non-Muslim, the key to the political economy of late Ottoman rule, led directly to the expulsion of Greeks from what remained of Turkey after the Greek-Turkish War. ${ }^{108}$ In 1857, The Times had been able to boast of London's financial (and, by extension, political) superiority vis-à-vis Istanbul: “The Turks have a fine territory and no money, energy, or skill; we have all three, and they pour into Turkey as naturally as water finds its level". ${ }^{109}$ Likewise, the Moniteur ottoman, the Porte's official newspaper, had lauded the capitulations as the key to Turkey's economic openness: "In no part of the world does foreign merchandise pay so low an import duty as in Turkey .... [F]or the space of three hundred years the Sultans have realized an object which civilized Europe is now earnestly labouring to accomplish". ${ }^{110}$ No longer, it was believed, would such brash expressions of overconfidence by foreigners and overt avowals of co-optation by local elites go unanswered.

In sum, the population transfers and exchanges of the 1910s and early 1920s cannot be understood absent an appreciation of the revanchism fostered by Turkish nationalists - first by the Committee of Union and Progress, and later, more systematically, by the Kemalists - in an effort not simply to cope with but positively to capitalize upon the confusion caused by war and displacement. If the revitalized international law envisioned by the diplomats of Versailles and

106 See, e.g., Ladas, supra note 29, at 729; Dimitri Pentzopoulos, The Balkan Exchange of Minorities and Its Impact upon Greece (Paris: Mouton \& Co / École pratique des hautes études, 1962) at 102; and, for a broader analysis, Elisabeth Kontogiorgi, "Economic Consequences following Refugee Settlement in Greek Macedonia, 1923-1932" in Renée Hirschon, ed., Crossing the Aegean: An Appraisal of the 1923 Compulsory Population Exchange between Greece and Turkey (New York: Berghahn, 2003) 63.

107 See, e.g., Kemal Ar1, Büyük Mübadele: Türkiye'ye Zorunlu Gọ̈c (1923-1925) (İstanbul: Tarih Vakf1 Yurt Yayınlar1, 1995) at 177; Aktar, supra note 24, at 46-7; and, for some statistics, see Mehmet Çanl, "Yunanistan'daki Türklerin Anadolu'ya Nakledilmesi I" 129 (1994) Tarih ve Toplum 54 at 59-60.

108 Haldun Gülalp, "Capitalism and the Modern Nation-State: Rethinking the Creation of the Turkish Republic" 7 (1994) Journal of Historical Sociology 155 at 158-9.

${ }_{109}$ Quoted in A. P. Thornton, Doctrines of Imperialism (New York: John Wiley \& Sons, 1965) at 101.

110 "On Freedom of Commerce in the Ottoman Empire" Moniteur ottoman [n.d.], reproduced in David Ross, ed., Opinions of the European Press on the Eastern Question. Translated and Extracted from Turkish, German, French, and English Papers and Reviews (London: James Ridgway \& Sons, 1836) 1 at 4-5, 6. 
fostered by the lawyers and functionaries of the League of Nations was to facilitate the construction of a "new Turkey" projecting stability throughout the eastern Mediterranean, this would be due in no small part to the efforts of a Turkish nationalist movement committed to creating a "modern" Western nation-state. As the ultima ratio of the international law of minority protection in a region in which minority protection itself could not but have limited traction, population exchange was thought to be a necessary evil. Turkey may, as one contemporaneous writer noted, have been "taking a leaf out of Western political conceptions" of national statehood, but it was also committing itself to a mechanism of nation-building that the West itself was not yet able to stomach. ${ }^{111}$

\section{Toward a Definitive Arrangement}

Drawing out the specifically legal implications of this rather messy sequence of events - some, like the treaties of the 1910s, of an explicitly legal character, others, like the Committee of Union and Progress' activities, more generally social, political, or economic - is no simple matter. The assumption that claims to statehood warranted recognition only insofar as the state whose existence was thereby called into existence housed a specific nation had received support from legal and political scholars for some time prior to the 1910s. As early as Vattel's Le droit des gens, one finds hints that the state is best conceived as a kind of outward representation of the nation; Vattel himself sometimes presents the latter as logically, or perhaps even temporally, prior to the former. ${ }^{112}$ And in the form of the famous "principle of nationality", the attempt to conjoin statehood tightly with nationhood would be deployed with devastating force by Mazzini in the mid-nineteenth century and go on to figure prominently in the writings of political theorists and international lawyers in the late nineteenth and early twentieth centuries. Rudolf von Jhering would write that "an iron hand" is needed "for nations to get back from a condition of political barbarism to one of political order", ${ }^{113}$ Heinrich von Treitschke would

111 Winthrop D. Lane, "Why Greeks and Turks Oppose Being 'Exchanged" 18 (1923) New York Times Current History 86 at 90.

112 One example: "Le Souverain répréfente fa Nation entiére, il en réunit dans fa perfonne toute la Majefté". Emer de Vattel, Le droit des gens. Ou Principes de la loi naturelle, appliqués à la conduite et aux affaires des Nations et des Souverains, Vol. I (Londres: n.p., 1758) at 285.

113 Rudolf von Jhering, Law as a Means to an End, tr. Isaac Husik (Boston: Boston Book Company, 1913 [1877]) at 235. 
argue that "[i]n a single State the whole range of culture could never be fully spanned", ${ }^{114}$ and T. J. Lawrence would explain that Staatenbunden like Switzerland belonged to a "lower type of union" and were "in a condition of unstable equilibrium", the only truly secure state being that which housed one, and only one, nation. ${ }^{115}$ These and similar views exerted considerable influence over Turkish jurists, who received them as part of a convoluted process of transfiguring and appropriating European legal codes, and European legal thought more generally. ${ }^{116}$ (Henri Bonfils' handy Manuel de droit international public had, for instance, been rendered into Ottoman Turkish in 1908 as Hukuk-i Umumiye-yi Düvel, and would before long benefit from wide circulation. ${ }^{117}$ ) By the 1910s, the influence had become so palpable that Mahmut Esat, later to become the Turkish Republic's first minister of justice and its agent before the Permanent Court in the Lotus case, could structure the entirety of his doctoral dissertation around an argument to the effect that the Ottoman capitulations were incompatible with the specifically national character of the modern state. ${ }^{118}$

Still, it was not until the 1910s that there emerged a body of international treaty law capable of regulating and facilitating en masse migration with a view to achieving this mutual alignment of nation and state. If minority protection was nominally a norm in central and eastern Europe, enshrined in international treaties and constitutionally incorporated into domestic legislation, then transferring and exchanging populations was this norm's exception in Europe's near abroad, the application of minority protection's goal of domesticating ethnonationalism to conditions in which minority protection itself was deemed insufficient. Put differently, the international law of population exchanges was developed as part of a drive to resolve inter-ethnic and inter-confessional conflicts through less conventional methods than minority protection. Shuffling large numbers from one side of the Aegean to the other, or from

\footnotetext{
114 Heinrich von Treitschke, Politics, tr. Blanche Dugdale and Torben de Bille (London: Constable and Co., 1916 [1897-8]) at 16 .

115 T. J. Lawrence, The Principles of International Law, $4^{\text {th }}$ Ed. (Boston: D. C. Heath \& Co., 1910) at 70.

116 For surveys, see Esin Örücü, "The Impact of European Law on the Ottoman Empire and Turkey" in W. J. Mommsen and J. A. de Moor, eds., European Expansion and Law: The Encounter of European and Indigenous Law in 19thand 20th-Century Africa and Asia (Oxford: Berg, 1992) 39; Gülnihâl Bozkurt, Batı Hukukunun Türkiye'de Benimsenmesi: Osmanl Devleti’nden Türkiye Cumburiyeti’ne Resepsiyon Süreci (1839-1939) (Ankara: Türk Tarih Kurumu Bas1mevi, 1996), part 2.

${ }^{117}$ For some details, see Cemil Aydin, The Politics of Anti-Westernism in Asia: Visions of World Order in Pan-Islamic and Pan-Asian Thought (New York: Columbia University Press, 2007) at 231, fn.

118 Mahmoud Essad, Du régime des capitulations ottomanes: leur caractère juridique d'après l'histoire et les textes (Stamboul: S. A. de papeterie et d'imprimerie, Fratelli Haim, 1928). The dissertation had been defended in Fribourg in 1919. For the way in which this stance fed Esat's litigation strategy in the Lotus case, and of its reception by the Permanent Court, see generally The Case of the S. S. "Lotus" (France v. Turkey) PCIJ Rep. Series A No. 10 (1927).
} 
one stretch of the Balkans to another, would diminish the risks of majority-minority conflict by furthering the ethnic homogeneity of each concerned state. And it would do so in a distinct way - not limited to standard European mechanisms of minority protection, but also clearly distinct from the neo-colonialism of the mandates system. 


\section{CHAPTER III.}

\section{"A Subject Which Excites the Deepest Interest throughout the Civilised World"1: Lausanne and the Craft of Diplomatic Nation-Building}

Lausanne was in many ways a natural location for a conference to bring Turkey's involvement in the Great War to an end. There was, of course, Switzerland's age-old isolation from continental rivalry. And then there was the fact that Turkish nationalism had maintained a curiously close relationship with the city and its university. Many members of the Young Turk elite, and of the Kemalist intelligentsia which succeeded it, held doctoral degrees, often in law, from Swiss universities. Lausanne itself was so favourite a destination that a Swiss jurist who served as advisor to the Turkish government after the peace conference would note that some members of the Committee of Union and Progress were referred to as "les Lausannois". ${ }^{2}$ Even so, the conference has long been remembered for its duration: the proceedings commenced in November 1922 and none of the instruments save the convention regulating the exchange and a related agreement on the restitution of interned civilians and exchange of prisoners of war were signed until July of the following year, the disagreements ranging widely and reaching at times a fevered pitch. This acrimoniousness was a by-product of ongoing disputes between the Kemalists and their antagonists - disputes played out within a shared socio-linguistic field informed in great part by the international legal doctrine of the day.

In this chapter I turn to two of the most illuminating aspects of Lausanne's preparatory work - the various delegations' views on the place of ethno-nationalism in the exchange process, and the exchange's design as a mechanism geared to a specific region, one which abutted, but was not integral to, Europe. Was the exchange simply the product of an elite demographic engineering enterprise legitimized in advance by a "science" of nation-building and necessitating little if any direct engagement with ethnicity? Or did it call for such

\footnotetext{
1 Lord Curzon's characterization of "the question of the protection of minorities", which he, like others at Lausanne, linked tightly to the issue of "the great transference of populations". TMC minutes (12 December 1922), in Lausanne Conference on Near Eastern Affairs (1922-1923): Records of Proceedings and Draft Terms of Peace, Cmd. 1814 (London: His Majesty's Stationery Office, 1923) at 173, 175177.

2 Georges Sauser-Hall, "La réception des droits européens en Turquie" in Recueil de travaux publié à l'occasion de l'Assemblée de la Société suisse des juristes à Genève, du 4 au 6 septembre 1938 (Genève: Imprimerie Albert Kundig, 1938) 323 at 345. For details, see Masami Arai, Turkish Nationalism in the Young Turk Era (Leiden: Brill, 1992) at 76-80; and, more comprehensively, Hans-Lukas Kieser, Türklüğe İbtida: 1870-1939 İsviçre'sinde Yeni Türkiye'nin Öncüleri, tr. Atilla Dirim (İstanbul: İletişim, 2008).
} 
engagement from the very beginning, romanticized notions of popular will undergirding the otherwise technical business of coordinating migration, settlement, and compensation? If both were at work in the negotiations, how exactly was this so? Was there, perhaps, something regionally specific, something distinctively "Near Eastern", about the population exchange?

I first argue that debates regarding the exchange were informed by a profound ambiguity in regards to ethno-nationalism. On the one hand, the exchange was a technocratic effort to bracket ethno-nationalism, or at least to minimize its attraction by ensuring that the movements already underway were governed by law and that conflict was therefore kept to a minimum. On the other hand, the exchange tethered the sovereignty of Greece and Turkey to the ethnicities of their "founding peoples", recruiting - and legitimizing - the very ethnonationalism which had made the exchange procedure necessary. I then argue that the exchange comprised a method of nation-building with a distinct range of spatial application. If some doubted the wisdom of implanting minority protection in central and eastern Europe, room for doubt was that much greater in the case of Greece and Turkey, where the need for a "more radical remedy" to "minority problems" was widely felt. ${ }^{3}$ Likewise, though the idea of a mandate had won support even among some Turks, ${ }^{4}$ establishing a mandate over any predominantly Turkish territory had never been more than a remote possibility. ${ }^{5}$ Indeed, if the exchange proved as adept at curbing ethno-nationalism as it did, this was due mainly to the fact that it had been designed with the characteristics of a particular region in mind - a region whose semi-peripheral status demanded a mechanism that departed radically from minority governance (in Europe) and mandatory rule (beyond Europe).

\section{Bargaining Ethno-Nationalism}

\footnotetext{
3 A. A. Pallis, "The Exchange of Populations in the Balkans" 97 (1925) The Nineteenth Century and After 376 at 377. ${ }^{4}$ See, e.g., Stanford J. Shaw, From Empire to Republic: The Turkish War of National Liberation 1918-1923: A Documentary Study, Vol. II (Ankara: Türk Tarih Kurumu Basimevi, 2000) at 429-37. For related proposals, see Tar1k Zafer Tunaya, Türkiye'de Siyasal Partiler, Vol. II, $2^{\text {nd }}$ Ed. (İstanbul: Hürriyet Vakfi Yayınlar1, 1986) at 245-63.

5 The most radical Turkish reaction is captured accurately, albeit hyperbolically, in the words of a contemporaneous publicist: " $[\mathrm{H}]$ aving lived independently for a thousand years, the Turks will not allow foreigners to so much as ride horses in their country under the pretence of a mandate or trusteeship". Ahmet Selâhattin Bey, "Vekâlet ve Müzaheret", [1919] Tarik, reproduced as "Mandat ve Yardım" in Lozan'm 50. Yıl Armağan (İstanbul: Fakülteler Matbaas1, 1978) 3 at 6 (translation mine).
} 
The sub-commission tasked with negotiating the terms of the Greek-Turkish exchange met on more occasions than any other at Lausanne, ${ }^{6}$ and its minutes testify to a concerted effort on the part of all delegates to put an end to the violence with which the Near East had come to be so closely associated. The exchange's relationship to ethno-nationalism raised a complex array of issues that tended to be approached from two very different angles.

The first such angle elided ethno-nationalism altogether, and did so in the name of a need to "unmix" the peoples of the Near East through the most rational, technically sophisticated means available. Frequently employed by the great powers, but also finding a home in some of Turkey's own demands, this was a strategy driven by a preponderantly managerial analysis of the territorial frontiers and demographic compositions of the two states to be reconstructed by the exchange. The argument on its behalf had as its major premise the conjecture that the exchange could be conceived and implemented in abstracto - as a fundamentally self-contained enterprise, fuelled by what one contemporaneous jurist deftly termed the "constructive and practical idealism"7 then being developed by League officials. This enterprise would, to be sure, bump up against ethno-nationalism. Yet it would retain an irreducibly "scientific" core of intentional design, strong enough to impede, or at least defer, the international system's disintegration in the face of such nationalism. ${ }^{8}$

Thus, efforts to reconfigure the region did not imply an "intention to attack the sovereignty of Turkey" - and even less a wish to intervene so as "to create an imperium in imperio or a State within a State". "Rather, as emphasized by Nansen, who, as the League's High Commissioner for Refugees, would inaugurate discussion on the question of the exchange, the impetus behind moving hundreds of thousands of people from one end of the Aegean to the other was an overwhelmingly pragmatic one: "the Great Powers are in favour of" an exchange, he said, "because they believe that to unmix the populations of the Near East will tend to secure the true pacification of the Near East", this being "the quickest and most efficacious way of dealing with the grave economic results which must result from the great movement of

\footnotetext{
${ }^{6}$ A total of twenty-four, the next closest sub-commissions being those responsible for issues of property and contract and for minority protection strictly understood. For a tabulation see the explanatory note in Lausanne Conference, supra note 1 , at ii.

7 Arnold D. McNair, "Equality in International Law" 26 (1927) Michigan Law Review 131 at 135.

${ }^{8}$ Cf. Nathaniel Berman, "But the Alternative is Despair': European Nationalism and the Modernist Renewal of International Law" 106 (1993) Harvard Law Review 1792 at 1864 ff (analyzing attempts to impede "the cracking of the surface of the state system by nationalist desire").

9 TMC minutes (9 January 1923), in Lausanne Conference, supra note 1, at 289, 299.
} 
populations which has already occurred". ${ }^{10}$ Lord Curzon, lead British delegate and former viceroy of India, ${ }^{11}$ went out of his way to reassure the Turks - to whom he was otherwise openly hostile ${ }^{12}$ - that "[n]o one wanted to interfere with their independence or sovereignty". On the contrary, "everyone wanted to build up a sovereign independent Turkish State", but felt that "no solution would ever be reached if every statement made were to be met by Turkey wrapping herself up in her cloak and saying that [Allied proposals were] incompatible with her sovereign independence". ${ }^{13}$ Whatever may have been the personal and professional motivations at work here, such statements had the effect of rendering the exchange ascetic and unassuming, something of a mechanical exercise lying at a distance from the dirty business of attending to particular ethno-national aspirations. The socio-historical context within which any prospective exchange would need to take place was to be given short thrift, or at most given no more consideration than was required to ensure that the process generated a successful outcome.

A second approach struck a very different note. Most of those present in Lausanne were also wont to see ethno-nationalism as deeply integral to the exchange, albeit for different reasons and with different degrees of demonstrated conviction. The Turkish delegation generally preferred to throw its weight behind the proposition that debates relating to the international legal form of the exchange could not be disconnected from questions concerning the ethnic composition of the future Turkish state. Turkey had experienced more than its share of violence - and by no means only in the context of the Armenian genocide. In its eyes, much of this violence had been linked to Western powers exploiting extraterritorial privileges and immunities afforded by consular jurisdiction or exercising treaty-based rights of guardianship

10 TMC minutes (1 December 1922), in Lausanne Conference, supra note 1, at 111, 114.

11 A tenure during which he seems to have attempted to partition Bengal by separating Hindus and Muslims. Eric D. Weitz, "From the Vienna to the Paris System: International Politics and the Entangled Histories of Human Rights, Forced Deportations, and Civilizing Missions" 113 (2008) American Historical Review 1313 at 1337. For original materials pertaining to his time in India, see George Nathaniel Curzon, Lord Curzon in India: Being a Selection from His Speeches as Viceroy and Governor-General of India 1898-1905 (London: Macmillan, 1906). A contemporaneous assessment can be found in H. C. Lipsett, Lord Curzon in India 1898-1903 (London: Everett \& Co., 1903).

12 As an American delegate wrote in his personal diary, "Curzon seemed to have no understanding of the Turkish national aspirations; he did no good to the cause of the Allies by browbeating Ismet at the conference table as if the latter had been one of his 'natives' in India". Joseph C. Grew, Turbulent Era: A Diplomatic Record of Forty Years, 1904-1945, ed. Walter Johnson, Vol. I (Boston: Houghton Mifflin Co., 1952) at 553. Similarly, the memoirs of Turkey's second highest ranking delegate speak of the Allies' lack of appreciation for the Turks' "new mentality". Rıza Nur, Lozan Hatıraları (İstanbul: Boğaziçi Yayınları, 1999) at 50 (translation mine).

13 TMC minutes (13 December 1922), in Lausanne Conference, supra note 1, at 204, 214. 
over Christian communities. ${ }^{14}$ For İsmet Paşa, the chief Turkish delegate, Turkey's support for a compulsory exchange followed from its "legitimate desire to prevent minorities in Turkey becoming weapons in the hands of foreigners". ${ }^{15}$ So long as Turkey harboured sizable and resourceful non-Muslim communities, willing and able to assist Western powers as fifth columnists, it would be unable to achieve internal security and contribute to international peace.

Statements from other participants can be read in similar terms - as attempts not to displace ethno-nationalist politics so much as to harness it to a project of international legal nation-building. Portraying the exchange as a method of effecting Turkish withdrawal from Europe, Curzon, for instance, would suggest that, with the exchange, "[i]n Europe the greater part, if not the whole, of the Turkish population in Greek territory ... will cease to be a minority population because they will return to Turkey". ${ }^{16}$ Why "return"? What exactly did use of this term entail? As the only Turks to whom this comment could apply were natives of the Balkans, the implication was clearly that Turkish presence in Europe remained - after nearly six centuries of Ottoman presence in the Balkans and several centuries of earlier Turkic Völkerwanderungen - an essentially, irredeemably, alien one. The Turks, Curzon was suggesting, were a jarringly foreign presence, physically occupying European territory, yes, but culturally and religiously set apart from - or, at best, incidental to - "Europe". ${ }^{17}$ After all, even those episodes of apparent interpenetration between the "public law of Europe" and the dār al-Islam spearheaded by the Ottomans, such as Turkey's controversial admission into the European state system in the 1856 Treaty of Paris, owed more to raison d'etat than to any "cultural" or "civilizational" bond, Istanbul having acquired the attendant "advantages" largely to maintain the continental balance of power. Unlike the first approach, then, a managerial, technocratic approach to the exchange, this second approach saw the exchange as a messy, even sinister,

\footnotetext{
${ }^{14}$ Russia's move in the nineteenth century to merge its "humanitarian" vision for the Balkans with a distinctly postNapoleonic appeal for national independence for Slavic peoples is a classic case in point. After Napoleon, Russia "n'intervient plus dans les Balkans au seul nom de l'intervention d’humanité, mais au nom des nationalités". Boris Mirkine-Guetzévitch, "L'influence de la Révolution française sur le développement du droit international dans l'Europe orientale" 22 (1928-II) RCADI 295 at 424.

15 TMC minutes (13 December 1922), supra note 13, at 207.

16 TMC minutes (12 December 1922), supra note 1, at 177.

17 That this is neither a conjecture nor a one-time comment is evidenced by the fact that Curzon was given to making such statements regularly. "Personally", he once wrote, "I have always thought that the right policy was to turn the Turks out of Constantinople and confine them to Asia". On another occasion, he stated that "[t]he presence of the Turks in Europe has been a source of unmitigated evil to everybody concerned. I am not aware of a single interest, Turkish or otherwise, that during nearly 500 years has benefited by that presence." Quoted, respectively, in Shaw, From Empire to Republic, supra note 4, at 400; and Margaret MacMillan, Paris 1919: Six Months That Changed the World (New York: Random House, 2003) at 373.
} 
affair - something to be broached not only with "scientific" acumen, as through entire nationstates might be created by sheer dint of will, but also, and at least equally, by attending to ethnonationalism's lure.

Before considering in detail these two strands of argument - the one shirking direct, unmediated engagement with ethno-nationalism, the other geared precisely toward such engagement - it is worth underscoring the complexity of the diplomatic context within which the delegates at Lausanne worked. The exchange was debated against the background of a wide range of legal disputes - and this in spite of the fact that most delegates at Lausanne were not themselves lawyers. ${ }^{18}$ Most of these disputes involved political questions that pitted Kemalist Turkey against Britain, France, several other great powers, ${ }^{19}$ and even, in some cases, officials like Nansen from the League of Nations, an organization with which Turkey had yet to establish official relations. ${ }^{20}$ By way of these struggles, nearly always waged within a social arena bounded by the discursive structures of international law, the juridico-political architecture of post-Ottoman Turkey would be assembled.

Relations between Turkey and the Allies, and also among the Allies themselves, underwent rapid change in the months leading up to the conference. Though efforts had been made to ensure that the great powers would act in concert, they were unable to maintain a unified stance on all issues. Curzon secured the position of the conference's president, and, wielding enormous symbolic capital, would direct most discussions as primus inter pares. In this he was assisted by the fact that, as he himself would confess in private, he had "the art of getting on with Orientals" 21 an "art" bolstered by the intrepid work of British code-breakers, who supplied him with a constant stream of intercepted telegrams between Ankara and

\footnotetext{
${ }^{18}$ Most delegates at Lausanne were career diplomats rather than trained lawyers. In the case of Turkey, İsmet, the chief delegate, was a general, while Riza Nur, the second highest ranking delegate, was a physician. Even so, all delegations, the Turkish included, were supported by sizable contingents of legal and other advisers. Arguably the most influential lawyer within the Turkish delegation, Mehmet Münir (later Mehmet Münir Ertegün), had formerly served in the Ottoman ministry of foreign affairs, where he had been deemed of value for his analytical skills and strong linguistic proficiencies. İsmet drew on his services - both legal and linguistic - at Lausanne. See Bilâl Şimşir, Bizim Diplomatlar (Ankara: Bilgi Yayınevi, 1996) at 294-6.

19 The powers with a stake in the Lausanne negotiations were chiefly European. Japan, though present at the conference, had little interest in the Near East. The United States, also represented, used the negotiations mainly to contest European hegemony over Levantine trade through an "open door" policy. For a good illustration, see Thomas A. Bryson, "Admiral Mark L. Bristol, an Open-Door Diplomat in Turkey" 5 (1974) International Journal of Middle East Studies 450 at $453 \mathrm{ff}$.

${ }^{20}$ Turkey was not yet a member of the League; it would join comparatively late, in 1932.

${ }^{21}$ Quoted in Harold Nicolson, Curzon, The Last Phase, 1919-1925: A Study in Postwar Diplomacy (London: Constable \& Co., 1934) at 298.
} 
Lausanne. ${ }^{22}$ France had broken ranks with Britain, and also with Italy, adhering to those portions of the Sykes-Picot Agreement which had dealt with the partition of majority Arab territories but otherwise lending support and war matériel to the Turkish nationalists. ${ }^{23}$ Italy had had to drop its earlier demands for territorial compensation in Anatolia on account of Kemal's growing strength and the Allies' unwillingness to deliver on their promises to that effect, ${ }^{24}$ though Mussolini's personal presence at the conference assured Italian control over the strategically important Dodecanese. ${ }^{25}$

As already mentioned, the British had supported the Greek occupation of western Anatolia. But this support had not been unequivocal: in a classic illustration of multivectoral realpolitik, the Foreign Office had extended support to the Greek cause only to a degree, never so much that a failure on the part of the Greeks would jeopardize Britain's broader geopolitical ambitions. Any number of reasons can be cited for this: a desire to maintain nominally cordial relations with the French, insufficient domestic support for another costly foreign adventure, divided domestic opinion on the merits of the Treaty of Sèvres, and others. Above all, though, it was a calculated assessment of the risks inherent in the Greek expedition that underpinned British ambivalence. Ottoman Turkey was to have been Britain's cordon sanitaire on the road to India. ${ }^{26}$ Now that it had collapsed, the responsibilities of shielding the "Jewel of the Crown" were to be shifted to an appropriately enlarged Greece. ${ }^{27}$ But this, naturally, was a gamble, and

\footnotetext{
${ }^{22}$ G. H. Bennett, British Foreign Policy during the Curzon Period, 1919-1924 (London: St. Martin's Press, 1995$)$ at 91. The Turks caught on to this at a certain point: see "No. 154: Gazi Mustafa Kemal Paşa'dan Lozan'da Heyeti Murahhasa Riyasetine”, reproduced in Bilâl Şimşir, ed., Lozan Telgraflar: Türk Diplomatik Belgelerinde Loz̧an Barıș Konferansı, Vol. I (Ankara: Türk Tarih Kurumu Basımevi, 1990) 230. Curzon had ample experience in this regard, having established a battery of intelligence agencies during his tenure in India. Richard J. Popplewell, Intelligence and Imperial Defence: British Intelligence and the Defence of the Indian Empire 1904-1924 (London: Frank Cass, 1995), ch. 2.

23 Aryeh Shmuelevitz, "Atatürk's Policy toward the Great Powers: Principles and Guidelines" in Uriel Dann, ed., The Great Powers in the Middle East 1919-1939 (New York: Holmes \& Meier, 1988) 311 at 313; Michael Llewellyn Smith, Ionian Vision: Greece in Asia Minor, 1919-1922, 2nd Ed. (London: C. Hurst \& Co., 1998) at 240. For the agreement concluded between France and the Ankara government, the first the latter concluded with any west European state, see Agreement with a View to Promoting Peace, with Protocol relating thereto, Protocol concerning Its Coming into Force, and Exchange of Notes, signed at Angora, October 20, 1921, 54 LNTS 177.

${ }^{24}$ H. James Burgwyn, Italian Foreign Policy in the Interwar Period 1918-1940 (Westport: Greenwood, 1997 ) at 14.

25 Dilek Barlas, "Friends or Foes? Diplomatic Relations between Italy and Turkey, 1923-36" 36 (2004) International Journal of Middle East Studies 231 at 233.

${ }^{26}$ For a typical articulation, see Valentine Chirol, "Our Imperial Interests in Nearer and Further Asia" in The Empire and the Century: A Series of Essays on Imperial Problems and Possibilities by Various Writers (London: John Murray, 1905) 728 at $728 \mathrm{ff}$.

27 D. K. Fieldhouse, Western Imperialism in the Middle East 1914-1958 (Oxford: Oxford University, 2006) at 45. A memorandum circulated within the Foreign Office in 1920 read as follows: "The idea which prompted our support of Greece was ... the natural expression of our historical policy - the protection of India and the Suez Canal. For a century we had supported Turkey as the first line of defence in the Eastern Mediterranean. Turkey had proven a
} 
not one to which the Foreign Office would commit itself blindly. Among other things, a conflict with Turkey could lead to full-blown rebellion in British India, where support for Kemal was strong, especially as his nationalists were careful to portray themselves as engaged in a jih $\bar{a} d$ to save the caliphate. ${ }^{28}$

The Allies would try to weaken the Turkish camp even before the negotiations began by extending two invitations, rather than simply one, to "Turkey" - the first to Kemal's provisional government in Ankara, by then in effective control of most of Asia Minor, and the second to the sultan's court, so confined to Istanbul that Cemil Bilsel, one of the early Republic's foremost international lawyers, would later characterize it as having become "a wholly municipal government". ${ }^{29}$ The ploy was not subtle. By opting for two invitations, the Allies hoped to split the Turks, lessening the bargaining power Ankara had amassed after repulsing Allied forces. The initiative came to nothing, though, as Ankara had already denounced the Ottoman court as collaborationist. It rejected the proposal, and the parties agreed that the conference would be convened with Kemal's government as the sole representative of "Turkey". 30

All of this strengthened Turkey's hand. Rather than arriving in Lausanne as a defeated Central Power, the Turks made a point of presenting themselves as the commanding force on most issues, that of the population exchange included. Their strategy was dictated in most

broken reed and we fell back on the second line, the line from Salamis to Smyrna. Geographically the position of Greece was unique for our purpose: politically she was strong enough to save us expense in peace, and weak enough to be completely subservient in war." Quoted in Theo Karvounarakis, "End of an Empire: Great Britain, Turkey and Greece from the Treaty of Sevres to the Treaty of Lausanne" 41 (2000) Balkan Studies 171 at 172 (deemphasized from original).

${ }^{28}$ Azmi Özcan, Pan-Islamism: Indian Muslims, the Ottomans and Britain (1877-1924) (Leiden: Brill, 1997), ch. 6. Efforts to win support for Turkey among Muslims in India and elsewhere were not new; they had been deployed impressively by Abdülhamid II, the last sultan to wield effective authority, in the late nineteenth century. See especially Kemal H. Karpat, The Politicization of Islam: Reconstructing Identity, State, Faith, and Community in the Late Ottoman State (Oxford: Oxford University Press, 2001) at 211-4, 233-9. For the connection with Kemalist strategy, see Engin Deniz Akarlı, "The Tangled Ends of an Empire and Its Sultan" in Leila Tarazi Fawaz and C. A. Bayly, eds., Modernity and Culture: From the Mediterranean to the Indian Ocean (New York: Columbia University Press, 2002) 261 at $278-9$.

${ }^{29}$ M. Cemil [Bilsel], Lozan, Vol. I (İstanbul: Ahmet İhsan Matbaas1, 1933) at 444 (translation mine).

${ }^{30}$ Pointing to the invitation as illustrative of Istanbul's collaboration with Western powers, Kemal's Ankara assembly would go on to abolish the sultanate in early November 1922. See, e.g., Bülent Tanör, Osmanl-Türk Anayasal Gelismeleri (1789-1980) (İstanbul: Yap1 Kredi Yayınlar1, 1998) at 277-80. By that point, journalists had already recorded references by him to the sultan as "une poupée sans importance". "Extrait du journal Le Figaro (Paris) du 1.10.1922 - une interview de Mustapha Kemal", in Bilâl Şimşir, ed., Dıș Basında Atatürk ve Türk Deurimi, Vol. I (Ankara: Türk Tarih Kurumu Basımevi, 1981) 36 at 38. 
respects by the nationalist movement's founding charter, the "National Pact". ${ }^{31}$ Drafted three years earlier, this document stipulated that independence for "the Turkish people" was a sine qua non for any lasting resolution to the "war in the East". Its sixth article concentrated the full force of this position, proclaiming that "complete independence and liberty" constituted "a fundamental condition" of this "people's" "life and continued existence". ${ }^{32}$

Fixed on this imperative, the Turkish delegation argued in favour of a strong interpretation of sovereign equality. State sovereignty, it maintained, was inviolable, an absolute point of reference conditioned solely by the need to preserve the integrity of the international legal system. Absent a robust commitment to formal equality between nations, the new order the League's advocates hoped to produce would effectively be a dead letter. In espousing this position - which has long attracted charges of "positivism" the Bolsheviks, who had signed a "treaty of friendship" with Ankara the year before ${ }^{34}$ and backed many of the Kemalists' substantive claims. ${ }^{35}$ The Kemalists were highly ambivalent on proletarian revolution, ${ }^{36}$ but the alliance, which owed much to the Soviets' desire to avoid international isolation and shore up their southern flank, ${ }^{37}$ supplied them with much-needed leverage at Lausanne and also irked delegates from other parties, ${ }^{38}$ perhaps none more so than

31 Baskın Oran, "Lausanne Barış Antlaşması" in Baskın Oran, ed., Türk Dış Politikası: Kurtuluş Savaşından Bugüne Olgular, Belgeler, Yorumlar (İstanbul: İletişim, 2001) 215 at 219.

32 "National Pact", as reproduced in Arnold J. Toynbee, The Western Question in Greece and Turkey: A Study in the Contact of Civilisations, 2nd Ed. (London: Constable and Co. Ltd., 1923) at 209, 210.

33 See, e.g., Alfred-Maurice de Zayas, "International Law and Mass Population Transfers" 16 (1975) HILJ 207 at 224.

34 Treaty of Friendship between Russia and Turkey, Moscow, March 16, 1921, 118 BFSP 990. For analysis, see especially Bülent Gökay, A Clash of Empires: Turkey between Russian Bolshevism and British Imperialism, 1918-1923 (London: Tauris, 1997) at 109-12.

35 Above all, that respecting the status of the Turkish straits: see, e.g., TMC minutes (8 December 1922), in Lausanne Conference, supra note 1, at 154-65. Cf. Ali Fuad, La question des Détroits: ses origines, son évolution, sa solution à la Conférence de Lausanne (Paris: Imprimerie du Montparnasse et de Persan-Beaumont, 1928) at 135-43; Samy Kabbara, Le régime des Détroits (Bosphore et Dardanelles) avant et depuis le traité de Lausanne (Lyon: Imprimerie BOSC Frères \& RIOU, 1929) at 88-98.

36 As some Bolsheviks were well aware; see, e.g., Sultan Galiev, "The Social Revolution and the East" [1919] in Alexandre S. Bennigsen and S. Enders Wimbush, eds., Muslim National Communism in the Soviet Union: A Revolutionary Strategy for the Colonial World (Chicago: University of Chicago Press, 1979) 131 at 137.

37 Archival records indicate that Kemal's representatives made it clear to their Bolshevik counterparts that Ankara would support Moscow's designs on the Caucasus. In turn, the Bolsheviks assured the Kemalists that forging an alliance was key to the Soviet state's survival, and that Russia's large Muslim population was exceedingly anxious to maintain direct land ties with its co-religionists to the south. Arsen Avagyan, "Kemalistler, Ittihatçlar ve Bolşevikler: Kurtuluş Şavaşı'nda Ankara-Sovyet İlişkileri” 159 (2007) Toplumsal Tarih 14 at 18-9. See also the earlier Soviet Appeal to Muslim Workers in Russia and the East, 3 December 1917, reproduced in Hurewitz, Diplomacy in the Near and Middle East: A Documentary Record: 1914-1956, Vol. II (New York: Octagon, 1972) 27.

38 See, e.g., TMC minutes (14 December 1922), in Lausanne Conference, supra note 1, at 216, 217. 
Curzon, who had previously chaired a British governmental committee formed to combat Bolshevism in the Middle East. ${ }^{39}$ Indeed, it allowed them to treat Lausanne as a kind of prolongation of war by other means. After all, a large Greek army was prepared to cross the Maritza and march on Istanbul at a moment's notice, ${ }^{40}$ and İsmet, a key architect of the repulsion of Greek forces only two years earlier, likened the conference to a military struggle "which the Turkish delegation mobilized for and worked 24 hours around the clock". ${ }^{4}$

Consider the conference proceedings. The Territorial and Military Commission, one of several such commissions into which Curzon divided the conference, was, among other things, tasked with negotiating the terms of the exchange. Nansen was invited to address the conference at its eighth meeting on the ground that he "had for some time been in negotiation with both Turkey and Greece on the subject". ${ }^{42}$ He would take the opportunity to recount his experiences, having shuttled back and forth between Athens and Istanbul for months prior to Lausanne, and also to press for the immediate implementation of a comprehensive population exchange. Amid what turned out to be a pointed call to action, Nansen characterized the exchange as "a matter ... of real importance to the peace and economic stability of the Near East". ${ }^{43}$ He stressed that the idea of an exchange had won extensive support among elites in both Greece and Turkey, as well as of the great powers. Hence, unlike the mandates system, in which he was also invested, ${ }^{44}$ the exchange would not be an exclusive outgrowth of Western diplomacy, but would instead involve all concerned actors. ${ }^{45}$ Further, Nansen underscored his willingness to continue serving as a diplomatic go-between for the purpose of hammering out a

\footnotetext{
39 John Fisher, "The Interdepartmental Committee on Eastern Unrest and British Responses to Bolshevik and Other Intrigues against the Empire during the 1920s" 34 (2000) Journal of Asian History 1 at 2.

${ }^{40}$ Douglas Dakin, "The Importance of the Greek Army in Thrace during the Conference of Lausanne 1922-1923” in Greece and Great Britain during World War I: First Symposium Organized in Thessaloniki (December 15-17, 1983) by the Institute for Balkan Studies in Thessaloniki and King's College in London (Thessaloniki: Institute for Balkan Studies, 1985) 211.

41 Quoted and translated in Fatma Müge Göçek, "The Politics of History and Memory: A Multidimensional Analysis of the Lausanne Peace Conference, 1922-1923" in Israel Gershoni, Hakan Erdem, and Ursula Woköck, eds., Histories of the Modern Middle East: New Directions (New York: Columbia University Press, 2002) 207 at 214.

42 TMC minutes (1 December 1922), supra note 10, at 111, 113.

43 Ibid., at 113.

${ }^{44}$ Nansen was a member of the Permanent Mandates Commission. For contextual discussion, see Daniel Gorman, "Liberal Internationalism, the League of Nations Union, and the Mandates System" 40 (2005) Canadian Journal of History 449 at $471 \mathrm{ff}$.

45 "In addition to the support given to the proposal by the Great Powers, I understand that the two Governments principally interested both desire that an agreement should be made. The Turkish authorities have assured me on no fewer than four occasions that they are in favour of such an exchange. The Greek Government has given me the same assurance in a series of official documents." TMC minutes (1 December 1922), supra note 10, at 114.
} 
conclusive arrangement. Though he had already been able to "bring some small relief with the funds placed at [his] disposal by the members of the League to the starving refugees of both nationalities", "far more needed to be done and he alone was not in a position to do it. While Turkey was not a member of the League of Nations, Nansen felt comfortable suggesting to his "Turkish friends that they could confide their interests in this matter to the Council of the League with absolute confidence, and they would be in safe hands". ${ }^{47}$

Ultimately, what was most important for Nansen was that all of the state parties should get on with the business of organizing a coordinated exchange. The exchange was not an outbreak of ethno-nationalism in extremis, an inter-ethnic or inter-confessional catastrophe that had shattered what little balance of power had existed in the Near East, but simply a "matter", 48 a "question" that demanded a "quick and efficient" resolution "with a minimum of delay". 49 Moreover, if this was a "matter" which deserved "the immediate and earnest consideration ... of the delegates gathered in Lausanne", this was so first and foremost because of its "real importance to the peace and economic stability of the Near East". ${ }^{0}$ That "the economic aspect of the matter" was "a most important aspect" 51 was indeed a fact that could not be overlooked:

"More can be done by a prompt and efficient exchange of minority populations to prevent these disastrous economic results from coming about than by any other measure which can be taken. Such an exchange will provide Turkey immediately and in the best possible conditions with the population necessary to continue the exploitation of the cultivated lands which the departed Greek populations have abandoned. The departure from Greece of its Moslem citizens would create the possibility of rendering self-supporting a great proportion of the refugees now concentrated in the towns and in different parts of Greece." 52

The attendant "difficulties" were obviously "immense". ${ }^{3}$ Among other things, "the displacement of populations of many more than 1,000,000 people" would necessitate "uprooting these people from their homes, transferring them to a strange new country, ... registering, valuing and liquidating their individual property which they abandon, and ...

\footnotetext{
46 Ibid., at 113.

47 Ibid., at 117.

${ }^{48}$ See, e.g., ibid., at 113.

${ }^{49}$ Ibid., at 116-7.

${ }^{50}$ Ibid., at 113.

${ }^{51}$ Ibid., at 115.

52 Ibid., and also at 116.

${ }^{53}$ Ibid., at 114.
} 
securing to them the payment of their just claims to the value of this property". ${ }^{4}$ But these were "technical difficulties - difficulties, that is to say, of securing the just, prompt and efficient application of any agreement that may be made". ${ }^{55}$ And they were "not insuperable". Two members of the commission responsible for seeing through the earlier 1919 Greek-Bulgarian exchange had already assured Nansen of as much. ${ }^{57}$ The treaty which had governed this earlier exchange could, in fact, "be taken as a model". ${ }^{8}$ That Turkey and Greece were "in the fortunate position of having at their disposal experts in this question of exchange" would only make this easier. $^{59}$

It is striking that Nansen, anything but reticent on the exchange's organizational "machinery" (a term of his own choosing ${ }^{60}$ ), had little of substance to say about the fact that such an enterprise would involve not only the mobilization but also the legalization - and hence, by extension, legitimation - of a series of factual changes whose eventual outcome was to be a wholesale reconfiguration of the Near East's ethno-confessional map. Obviously, any exchange would need to be a product of methodical calculation, and in highlighting the need for such caution Nansen was reiterating a point around which a rough-and-ready consensus had already formed. But the exchange would also need to wrestle with - and to enlist - a considerable measure of völkisch romanticism, rendering it far less cut-and-dry an affair than the rather arid procedures on which Nansen pinned his hopes. Nansen himself was not prepared to recognize as much publicly at Lausanne: one searches in vain in his transcribed speech for an indication that "the economic aspect of the matter" was not for him of far and away the greatest importance. $^{61}$

None of this was lost on İsmet Paşa, the first to respond to Nansen's speech. Though Turkey was not a League member and could therefore attach no more than a "personal

\footnotetext{
54 Ibid.

55 Ibid., at 115.

56 Ibid.

57 Ibid., at 115-6.

58 Ibid., at 116.

${ }^{59}$ Ibid. It is not clear who precisely Nansen had in mind here. Given the context, one can only assume that he was referring to diplomats experienced in negotiating earlier transfers and exchanges.

${ }^{60}$ Ibid.

${ }^{61}$ A search of the French minutes yields similar results; see "Séance du vendredi 1er décembre 1922" in Conférence de Lausanne sur les affaires du Proche-Orient (1922-1923). Recueil des Actes de la Conférence, Vol. I (Paris: Imprimerie nationale, 1923) at 95, 96-9.
} 
character" to Nansen's statement, ${ }^{62}$ it agreed, he explained, that immediate progress needed to be made on the issue of an exchange. From Ankara's vantage-point, the exchange concerned a much broader set of issues than Nansen had suggested. The terms of the exchange could not be negotiated in the abstract; they were intertwined, at all levels, with the question of the legal status of minorities in the post-Ottoman Near East. Indeed, İsmet maintained, the problem of determining the form of the impending exchange could not be separated from the problem of determining what kind of legal arrangements would need to be made in order to manage majority-minority relations in the Near East. ${ }^{63}$ And this, in turn, testified to the exchange's testy relationship with ethno-nationalism: as the question of the exchange was closely related to that of minority protection, the former could not be broached, let alone resolved, without determining which groups were to be moved and which were to be afforded protection as national minorities.

This meeting of the Territorial and Military Commission came to an end without İsmet having an opportunity to elaborate his delegation's position in any great detail, but in subsequent meetings it soon became apparent that his attempt to conjoin the issue of the exchange tightly with that of minorities had serious implications for Turkey's stance in regards to ethno-nationalism. Already on 1 December İsmet had argued that, for Turkish authorities, the principal purpose of any exchange would have to be the definitive resolution of the "minorities problem". Ankara, he had explained, would insist that any exchange that might unfold would need to include Greeks resident in Izmir and Istanbul - both cosmopolitan centres of vital importance to commercial activity in the eastern Mediterranean, but both also lynchpins of the irredentist project of achieving a "greater Greece" ${ }^{64}$ In a long memorandum he read before a meeting on 12 December, ${ }^{65}$ İsmet went further. The memorandum proved to be an extended analysis of the place of minorities in Ottoman history, running the gamut from Mehmed II's grant of privileges to non-Muslims after the conquest of Constantinople to the

\footnotetext{
62 TMC minutes (1 December 1922), supra note 10, at 117. This brought a sharp rebuke from Curzon, who insisted that Nansen's status was irrelevant, the only pertinent issue being the fact that the exchange concerned the material interests of Greece and Turkey. Ibid., at 118. This stance was not entirely unfounded, as, in the long run, Nansen's humanitarian credentials appear to have facilitated the exchange rather than stifled it: as one biographer would later point out, "[i]f for no other reason, he had drawn the fire of public opinion". Roland Huntford, Fridtjof Nansen and the Unmixing of Greeks and Turks in 1924 (Oslo: Norwegian Academy of Science and Letters, 1999) at 15.

63 TMC minutes (1 December 1922), supra note 10, at 117.

64 Ibid., at 120.

65 "Statement read by Ismet Pasha", annex to TMC minutes (12 December 1922), supra note 1, at 190.
} 
high watermark of secessionist nationalism in the late nineteenth century and finally to "the lamentable Armenian question". ${ }^{66}$ Studded with purposefully selected passages from Voltaire ${ }^{67}$ and a litany of legal treatises, ${ }^{68}$ it was intended to establish that "[i]ntervention in the name of the Christian religion" had marked Turkey's relations with the West for centuries. ${ }^{69}$ While the Turks had "never failed to acknowledge the rights of the non-Moslem elements so long as the latter did not abuse the generosity of the country in which they lived in comfort" (a claim purportedly evidenced by the fact that Jews had only seldom complained of Turkish rule) ${ }^{70}$ they had been forced to quell uprisings among subject nationalities collaborating with Russia and other powers when the Empire went into decline.

For İsmet, a compulsory exchange guaranteed stability and development, curbing external interference and securing internal order. Ankara, he explained, believed that "the amelioration of the lot of the minorities in Turkey" depended "above all on the exclusion of every kind of foreign intervention and of the possibility of provocation coming from outside". ${ }^{71}$ It was convinced that this objective was achievable only through a comprehensive exchange, and that "the best guarantees for the security and development of the minorities remaining after the application of the measures for reciprocal exchange would be those supplied both by the laws of the country and by the liberal policy of Turkey with regard to all communities whose members have not deviated from their duty as Turkish citizens". ${ }^{72}$ A compulsory exchange was also useful as a response to the recent displacement of large numbers of Turks and Muslims in the Balkans. "[T]here were", İsmet stressed, "over a million Turks without food or shelter in countries in which neither Europe nor America took nor was willing to take any interest" ${ }^{73}$ Only an exchange could relieve these people of their plight, and in the process achieve a

\footnotetext{
${ }^{66}$ Ibid., at 197.

67 Ibid., at 191.

68 Chief among them Philip Marshall Brown's Foreigners in Turkey; Their Juridical Status (Princeton: Princeton University Press, 1914). Brown's book - a slim study growing out of his time in the American embassy in Istanbul - lent support to İsmet's position; see, e.g., at 23-4, 118. For İsmet's reference, see "Statement read by Ismet Pasha”, supra note 65, at 190-1.

${ }^{69}$ Ibid., at 192.

70 Ibid., at 201 and similarly at 203-4 ("As for the Jewish community, the spirit of loyalty which it has always shown to the Turkish Government leads to the presumption that its members will continue peacefully to collaborate with their Turkish fellow-citizens for the betterment and prosperity of the country."). See also TMC minutes (13 December 1922), supra note 13, at 208 (“[T] his hard-working and intelligent element ... deserved to be held up to all other sections of the population as a pattern of quiet and unruffled conduct.").

71 "Statement read by Ismet Pasha", supra note 65, at 204.

72 Ibid.

73 TMC minutes (12 December 1922), supra note 1, at 189.
} 
"neutralisation of the action of" irredentism and sectarian conflict. ${ }^{74}$ Turkey's earlier experiences with transfers and exchanges, which could serve as "valuable precedents" in this regard, ${ }^{75}$ had already confirmed as much, if largely in a negative fashion on account of their not having gone far enough.

Curzon would also link the issue of minorities to that of the population exchange. And he would also see this link as suggestive of a nervy relationship with ethno-nationalism. On the one hand, the exchange was "a thoroughly bad and vicious solution, for which the world would pay a heavy penalty for a hundred years to come". ${ }^{76} \mathrm{He}$ "deeply regretted" it, ${ }^{77}$ underscored "the suffering [it] entailed", ${ }^{78}$ and sought to minimize Allied responsibility by explaining that Western powers "had attempted to do no more than to act in the rôle of mediators", intervening only after the exchange had become unavoidable so as "to secure the conclusion of an agreement capable of practical application and of a character to reduce the inevitable suffering". ${ }^{79}$ On the other hand, Curzon was also at pains to note that should the exchange be implemented under the terms of a formal treaty, it would almost certainly result in "the question of the minorities" being "to a certain extent simplified". ${ }^{80}$ Even as he voiced discomfort with the exchange mechanism, and particularly its roots in an unruly ethno-nationalism, Curzon felt compelled to underscore its necessity, even desirability.

Statements made by other delegations displayed a structurally analogous ambivalence about ethno-nationalism. In a report to Curzon, Montagna, the chair of the Territorial and Military Commission's sub-commission on the exchange, noted that "the compulsory solution was regarded by everyone with repugnance" - only to follow it with the claim that " $[\mathrm{t}]$ aking the statistics of the Turkish delegation as a basis, we were able to prove mathematically that it was not necessary for Turkey to remove the Greeks of Constantinople in order to establish the Moslems of Greece on her territory". "B1 Barrère, chief negotiator for France, emphasized that conflict in the Near East could not be resolved without attending to the politico-economic

74 "Statement read by Ismet Pasha", supra note 65, at 202.

75 Ibid., at 203.

76 TMC minutes (13 December 1922), supra note 13, at 212.

77 Ibid.

78 TMC minutes (27 January 1923), in Lausanne Conference, supra note 1, at 406, 412.

${ }^{79}$ Ibid.

80 TMC minutes (12 December 1922), supra note 1, at 177.

81 "Report addressed to Lord Curzon, President of the First Commission, by M. Montagna, President of the SubCommission on the Exchange of Populations", annex to TMC minutes (10 January 1923), in Lausanne Conference, supra note 1, at 328, 330-1. 
consequences of the proposed exchange: "commercial, industrial and agricultural activity" was "necessary to every country for repairing damages due to a long series of wars and for exploiting undeveloped wealth", and Turkey could not "fail to recognise how vitally important it is for it to preserve certain educated, industrious and hard-working elements of the population". ${ }^{82}$ However, he also voiced a certain sympathy for Turkey's attempt "to develop itself as a nation, ... to assert its independent political existence, to reconcile all the requirements of progress with its own national tradition".83 The ethno-nationalist modernization project of which the exchange was so integral an element was not one that could simply be tossed aside.

Considered as a totality, Lausanne's travaux reveal a striking degree of vacillation in regards to the nature and purpose of ethno-nationalism in the exchange's design and implementation. Whether the exchange was to be understood as a submission to the ethnonationalist movements that had led to en masse migration and expulsion, or instead as a technocratic response to a potentially overwhelming security and economic crisis - at Lausanne, this was not a question to be answered so much as an ambiguity to be formalized.

\section{An Enterprise neither European nor Non-European}

The notion that the exchange mechanism marked a significant departure from European practices of nation-building, minority protection chief among them, was brought to the fore with especial force in two, closely related positions that İsmet adopted during the Lausanne negotiations. Both concerned questions at the heart of Turkey's attempt to reconstitute itself as a national state, but each was supported with a distinct line of reasoning.

The first such position stemmed from the belief - exceedingly common among Turkish nationalists after Sèvres and particularly after the Greek-Turkish War - that minority protection alone would not be up to the task of ensuring peace in the Near East. The League's protective mechanisms aimed to shield minority groups in situ, ensuring a modicum of domestic and international security without uprooting peoples from their "ancestral homes". While the Turkish delegation saw the question of the exchange as closely linked to that of minorities, and

\footnotetext{
82 TMC minutes (12 December 1922), supra note 1, at 181.
}

83 Ibid. 
while it was willing to concede that some protective instruments would need to be installed, it was adamant on limiting their application to non-Muslims, refusing flatly to countenance the kind of robust regime of minority protection that had become more or less pro forma in central and eastern Europe following the Paris Peace Conference. In line with the Ottoman millet system, minority protection was to be extended solely to Turkey's non-Muslim citizens; nonTurkish Muslims simply would not be recognized as members of minorities. Further diluting the force of whichever protective instruments would ultimately be introduced was the fact that the total number of non-Muslims in Turkey had fallen sharply during the war, and was fated to fall even further with the completion of the exchange. Given the demographic realities that would arise after the exchange had been completed, a full-blown minority protection regime was essentially superfluous: with the exchange, there simply would not be minorities of sufficient number or political weight to warrant instituting any such regime on Turkish soil. Thus, whichever instruments would be introduced could not bear anything more than a generic resemblance, both in form and in application, to those which had been installed in the newly formed states of central and eastern Europe. If protective mechanisms were to be transmitted to Turkey from one or another member of the European "belt of minority states", this could not but be a highly attenuated and circumscribed process.

The second position concerned the ambit of Turkey's sovereignty - or, to be more precise, the felt need to eradicate all forms of extraterritoriality so as to acquire and safeguard "the same rights as every nation that was sovereign, independent and master of its destinies". ${ }^{4}$ Ismet's position in regards to the complex issues that were raised by this general problematic of sovereignty - first and foremost, those concerning the conditions under which civil and criminal jurisdiction could legitimately be asserted - was one that was rooted firmly in history. In addition to according a significant degree of autonomy to its non-Muslim minorities through the millet system, the Ottoman Empire had always granted wide-ranging privileges and immunities to subjects of foreign sovereigns who were resident on Ottoman territory via an elaborate system of capitulations. ${ }^{85}$ The soon-to-be-established Turkish Republic could not

${ }^{84}$ Minutes of the Commission on the Régime of Foreigners' (CRF's) meeting on 2 December 1922, in Lausanne Conference, supra note 1 , at $465,469$.

85 As noted in Chapter I, the two systems - the one designed for the rimmi (the non-Muslim subject of an Islamic sovereign), the other for the müstemin (the non-Muslim foreigner resident on Islamic soil) - ran parallel in some ways, meshing to form complex jurisdictional arrangements; see, e.g., Lauren Benton, Law and Colonial Cultures: Legal Regimes in World History, 1400-1900 (Cambridge: Cambridge University Press, 2002) at 108-9. Still, their 
adhere to anything that smacked of these privileges and immunities; Turkish and non-Turkish jurists had long regarded them as anomalous and exceptional, ${ }^{86}$ and so an uncompromising, across-the-board abrogation of the extraterritorial regime they made possible was required. This, in turn, was an objective that stood a greater likelihood of being achieved with the nationalization project of which the population exchange was an integral part. After all, once the latter had been finalized, most of the material conditions which had engendered and justified the maintenance of the capitulatory regime would have evaporated: because the commercial "colonies" ${ }^{\prime 7}$ set up by European merchants and maintained largely by local nonMuslims would have disappeared, the capitulations would quite literally have come to be stripped of their material foundations, with Turkey thereby ceasing to be a "virtual open and free market for Europe". ${ }^{88}$ Unlike central and eastern Europe, where nation-building generated mechanisms to manage majority-minority relations, and hence greater levels of legally entrenched pluralism, the Turkish case was to be one of diminished decentralization, with the exchange facilitating the dismantling of the capitulatory regime.

Take, to begin with, the first of these two positions - that relating specifically to the issue of minority protection. In principle, İsmet was not opposed to minority protection, at least so long as it did not entail "exceptional treatment more rigorous than that applied to other countries" 89 and Turkish authorities remained free to adapt the relevant "provisions to the local needs and special position of the minorities in Turkey". ${ }^{00}$ Turkey was, he reminded his fellow

relation is open to interpretation and not entirely clear; see Maurits H. van den Boogert, The Capitulations and the Ottoman Legal System: Qadis, Consuls, and Beratlis in the $18^{\text {th }}$ Century (Leiden: Brill, 2005) at 30-1, 55-6.

${ }^{86}$ From a vast literature, see, e.g., James Lorimer, The Institutes of the Law of Nations: A Treatise of the Jural Relations of Separate Political Communities, Vol. I (Edinburgh: W. Blackwood \& Sons, 1883) at 313-4; John Westlake, Chapters on the Principles of International Law (Cambridge: Cambridge University Press, 1894) at 101-3; Elihu Root, "The Basis of Protection to Citizens Residing Abroad" in Elihu Root, Addresses on International Subjects, ed. Robert Bacon and James Brown Scott (Cambridge, MA: Harvard University Press, 1916) 43 at 48; Lassa Oppenheim, International Law: A Treatise, Vol. I, ed. Ronald F. Roxburgh, $3^{\text {rd }}$ Ed. (London: Longmans, 1920) at 34.

${ }^{87}$ The term was employed loosely by Allied delegates in reference to commercial establishments, a feature of eastern Mediterranean trade at least as far back as the fondachi operated for trading and tax-farming purposes by Genoese, Venetian, and other merchants during the Renaissance. For references to such "colonies", see, e.g., CRF minutes (28 December 1922), in Lausanne Conference, supra note 1, at 480, 483, 484, 496; CRF minutes (6 January 1923), in Lausanne Conference, supra note 1, at 508, 511. On their proto-history, see Kate Fleet, European and Islamic Trade in the Early Ottoman State: The Merchants of Genoa and Turkey (Cambridge: Cambridge University Press, 1999), esp. at 134-41.

${ }^{88}$ Thomas Naff, "The Ottoman Empire and the European States System" in Hedley Bull and Adam Watson, eds., The Expansion of International Society (Oxford: Clarendon Press, 1984) 143 at 158.

${ }^{89}$ TMC minutes (13 December 1922), supra note 13, at 210. See also TMC minutes (9 January 1923), supra note 9, at 301 .

${ }^{90}$ Ibid., at 292. 
delegates, "acutely sensitive" when it came to questions concerning its sovereignty and independence, as "up to the present day Turkish sovereignty had always been infringed on the plea of humanitarian considerations". ${ }^{11}$ It was willing to recognize "the rights of non-Moslem minorities in accordance with the principles accepted by various European States and embodied in treaties". ${ }^{92}$ But in a significant departure from post-1919 minority protection practices, which have often been seen as signalling a move away from the protection of religious freedom to the protection of ethno-linguistic autonomy, ${ }^{93}$ Turkey could not grant minority status to its nonTurkish Muslims. There simply "were no Moslem minorities in Turkey", and "no distinction was made either in theory or in practice between the various elements of the Moslem population". ${ }^{94}$

What is more, İsmet was also convinced that minority protection, in and of itself, would never be enough to keep Muslims and Christians from "tear[ing] themselves to pieces for nothing but the advantage of political interests". ${ }^{95}$ If the Allies insisted on concentrating on minority protection alone, and did not give the issue of a compulsory, full-scale exchange serious consideration, post-Ottoman Turkey would find itself in much the same situation as its imperial predecessor: just as the sultan's court in Istanbul had tried to contend with attempts by Russia and other European powers to splinter the Empire, so too would Ankara need to counter attempts on the part of the great powers, and perhaps even the League of Nations Council, to exploit their powers of supervision over minorities for political ends. The Turks had come to Lausanne prepared to acquiesce in a certain measure of minority protection but committed above all to the exchange: İsmet's delegation was, in fact, under strict orders that the exchange was to be its "main objective" in regards to the issue of minorities. ${ }^{96}$

\footnotetext{
91 TMC minutes (14 December 1922), supra note 38, at 219.

92 Ibid., at 221.

93 See, e.g., Mark Levene, "The Limits of Tolerance: Nation-State Building and What it Means for Minority Groups" 34 (2000) Patterns of Prejudice 19 at 28-9. But see Kalliopi K. Koufa and Constantinos Svolopoulos, "The Compulsory Exchange of Populations Between Greece and Turkey: The Settlement of Minority Questions at the Conference of Lausanne, 1923, and Its Impact on Greek-Turkish Relations" in Paul Smith, Kalliopi Koufa, and Arnold Suppan, eds., Ethnic Groups in International Relations (New York: New York University Press, 1991) 275 at 289.

94 TMC minutes (9 January 1923), supra note 9, at 301.

95 "Statement read by Ismet Pasha", supra note 65, at 203.

96 Şimşir, Lozan Telgraflar, supra note 22, at xiv (translation mine). On this see Ayhan Aktar, "Türk-Yunan Nüfus Mübadelesi ve Diplomasi” in Ayhan Aktar, Türk Milliyetçiliği, Gayrimüslimler ve Ekonomik. Dönüşüm (İstanbul: İletişim, 2006) 99 at 107-9.
} 
It is revealing, and well worth noting, that in making this argument İsmet took note of Clemenceau's letter to Paderewski on the occasion of the finalization of the Polish Minority Treaty, pointing in particular to Clemenceau's assurance that the League would take greater care when managing majority-minority relations than had the Concert of Europe. ${ }^{97}$ For İsmet, the policies Clemenceau articulated were predicated on the view that minority protection was applicable to some but not to all states, thereby falling foul of principles of sovereign equality and non-interference, ${ }^{98}$ and İsmet remained unconvinced by assurances of impartial supervision on the part of the League: "The present organisation of the League of Nations does not, in spite of the opinion of the French statesman, appear to be such as to avoid this serious defect [i.e. the possibility of great power interference]". ${ }^{99}$ This much had become clear, he added sharply, from "the aggressive designs of Greece on Turkish Asia Minor", in his view an exemplary "campaign of devastation and carnage intermingled with all kinds of abominable crimes". ${ }^{100}$ The only way forward, then, was to take concrete steps to alter conditions on the ground in such a way as to render "certain minorities inaccessible to provocations from outside"101 - that is, to proceed with "the most radical and humane remedy" of all, namely a total exchange of populations between the two countries. ${ }^{102}$ Once the exchange had been completed, neither foreign sovereigns nor even an international organization of the League's ambition would be able to undermine Turkey's national sovereignty, at least not with the kind of impunity which had been possible under Ottoman rule and which newly installed regimes in central and eastern Europe made possible. At root, it was "to the unity and indivisibility of

\footnotetext{
${ }^{97}$ See supra Chapter I notes 95-9 and accompanying text.

98 Bilsel's commentary on the negotiations makes the point starkly. With the institution of new mechanisms of minority protection after 1919, "powerful states were held to one standard, while other states were held to another". This demanded a decision: "Europe must choose between two paths: either everyone within a state must be as much a subject of the nation as a subject of the state, or else borders must be redrawn and population exchanges undertaken in accordance with nations in order to remedy the situation. There can be no state within a state.” M. Cemil [Bilsel], Lozan, Vol. II (İstanbul: Ahmet İhsan Matbaas1, 1933) at 266, 269 (translations mine).

99 "Statement read by Ismet Pasha", supra note 65, at 202.

100 Ibid., at 202-3. As already mentioned, Turkey did not maintain official relations with the League of Nations, and İsmet Paşa made a point of highlighting this in the aftermath of Nansen's introductory speech. However, it would eventually "come around" on this issue. As İsmet explained later in the conference, Turkey had always regarded the League "with all due respect and consideration" (TMC minutes (13 December 1922), supra note 13, at 209), and would take steps to join it once the terms of the peace had been settled and it had acquired a new international legal personality, though it still rejected Allied proposals to have a League representative stationed in Turkey in the interim (TMC minutes (9 January 1923), supra note 9, at 301 (İsmet "could not see any utility in it")).

101 "Statement read by Ismet Pasha", supra note 65, at 202 and similarly at 203 (speaking of "agitations from outside").

102 Ibid., at 203.
} 
Turkey" that Ankara bound itself most firmly. ${ }^{103}$ If all relevant "rights, duties, advantages and obligations" were now "to be shared by all Turkish citizens alike", this was so because the situation on the ground was soon to have been altered with a view to "bringing about perfect understanding between all Turkish citizens". ${ }^{104}$

Though they too favoured the exchange procedure, Allied delegates sometimes sought to persuade İsmet and his colleagues that Turkey should assimilate itself more closely to minority protection. Some delegates pointed to Ottoman traditions of legal pluralism to underscore the need for strong entitlements for non-Muslims. Curzon himself took time in one session to recount the various privileges which the millet system had extended to non-Muslim subjects of the sultan and which had been bolstered by unilateral decrees and multilateral treaties in the nineteenth century. Indeed, he suggested, even when the Ottoman Empire initiated its first full-scale modernization efforts, it did not strip its non-Muslim subjects of these privileges, but instead reinforced and further formalized them. From the rescript which launched the Tanzimat reforms of the early nineteenth century through the decree that accompanied the 1856 Treaty of Paris to the 1878 Treaty of Berlin itself, the sultans had prescribed new and renewed existing privileges, in both cases acting in what Curzon (with some justification) depicted as conformity with Shari' a tradition. These privileges ought, Curzon argued, to be enshrined in the laws to be promulgated by the Republic that was to be founded after Lausanne. It would also be preferable if the observance and implementation of such laws were placed under League authority. This would provide an effective means of ensuring Turkey's compliance with its international treaty obligations. ${ }^{105}$

Interestingly, a similar argument came from a Balkan delegate. İsmet had laid stress on external pressures when sketching the dissolution of Ottoman authority in southeastern Europe, playing up Russia's role and marginalizing nationalist forces endogenous to the region itself. In response to this, Spalaikovitch, representing the Serb-Croat-Slovene state, tried to turn İsmet's analysis on its head by insisting that he ignored a "second factor" - namely, "the feeling of the Christian nationalities in the Balkans, who were unable to forget their national ideals". ${ }^{106}$ It was "this national feeling", Spalaikovitch argued, which had "played a decisive rôle in the

103 TMC minutes (9 January 1923), supra note 9, at 302.

104 Ibid.

${ }^{105}$ For the argument in full, see TMC minutes (14 December 1922), supra note 38, at 222-3.

106 TMC minutes (12 December 1922), supra note 1, at 187. 
creation of all modern States", those of central and eastern Europe included. ${ }^{107}$ And it was this same "national feeling" that drove "the present birth of a new, Kemalist, national Turkey". ${ }^{108}$ The legal implications were obvious: just as minority protection had been adopted by the newly formed or reformed states of central and eastern Europe, at least nominally, so Turkey would have to submit to the "practical system" which had arisen out of the war and which had "been adopted by all civilised nations". ${ }^{109}$ Turkey should not be worried that compliance with this new order would injure its sovereignty. There had been an "evolution" in "the legal ideas and institutions of Europe as regards the international problem of minorities", and "[t]he days of individual or collective intervention" were "over". ${ }^{110}$ Turkey could not "exclude herself from" this order, this "new régime of universal international law", so long as "she really desire[d] to take her place among modern States". ${ }^{11}$

İsmet was happy to concede that Turkey would need to undertake comprehensive reforms to "take her place among modern States". But he was not willing to go so far as to claim that it needed to bring its legal and administrative institutions entirely in line with central and east European practices. Again, the issue of minorities was linked closely to that of the exchange, and minority protection was to be extended to the few non-Muslim communities that were to remain in Turkey after the exchange. But it was this exchange, and not minority protection itself, that would do most of the difficult work in curbing violence in the region: physical segregation of Greeks and Turks would yield functional stability, reining in an ethnonationalism to which a certain deference was to be extended but which could not be permitted to run amok; minority protection would serve as an ancillary mechanism, minimizing whatever majority-minority tensions might still remain after the exchange had been completed. And, in a piercing turn, İsmet warned that any breakdown in the negotiations resulting from protracted disagreement on the question of minority protection would more than likely help, rather than hinder, Ankara's hand in the long run: "Should a rupture take place ..., and should the minorities problem be regarded as a convenient pretext for it, the Turkish delegation were convinced that, once these truths were known, the voices raised in favour of the Turkish

\footnotetext{
107 Ibid.

108 Ibid.

109 Ibid., at 188.

110 Ibid.

111 Ibid.
} 
delegation would come not only from Angora, but also from the conscience of all peoples". ${ }^{112}$ That Ismet had in mind potential revolts in the colonial world, particularly in India, where British power was being tested and support for Kemal had yet to wane, is not difficult to gather. Insisting on minority protection pure and simple was not an option here.

Second, and as something of a supplement to this first argument, experience with the Ottoman capitulatory regime had, İsmet argued, taught the Turks to be highly suspicious of decentralization. In another long-winded and heavily historical memorandum, this one read before the Commission on the Régime of Foreigners on 2 December 1922, roughly a week prior to his memorandum on the state of minorities in Turkey before the Territorial and Military Commission, İsmet maintained that the abrogation of the capitulations was permitted to Turkey under international law. ${ }^{113}$ To begin with, a careful analysis of the documentary record supported the decades-old Turkish argument that the capitulations were "essentially unilateral acts". ${ }^{114}$ Some European jurists may have interpreted the capitulations, anomalous though they were, as international treaties, ${ }^{115}$ but, in truth, they could not be characterized as such, at least if "treaty" was understood strictly to mean an instrument imposing legally binding obligations on all state parties. They had instead to be understood as decree-like grants of privileges by the sultan of a limited and essentially revocable nature. That Turkey was now going ahead and exercising its right to revoke them could not, therefore, be held against it. ${ }^{116}$

112 TMC minutes (14 December 1922), supra note 38, at 220.

113 "Memorandum read by the Turkish Delegate at the Meeting of December 2, 1922, of the Commission on the Régime of Foreigners", annex to CRF minutes (2 December 1922), supra note 84, at 471.

114 Ibid., at 478. See also CRF minutes (2 December 1922), supra note 84, at 469.

115 That the capitulations were treaties sensu stricto was often simply assumed rather than argued for. Thus, the most comprehensive pre-Lausanne study of the capitulations, G. Pélissié du Rausas's Le régime des capitulations dans l'Empire ottoman, Vol. I (Paris: Imprimerie C. Saillard, 1902) began with the sentence (at 1) that "[1]a condition des étrangers dans l'Empire Ottoman est réglée par une série de traités intervenus entre la Porte et la plupart des Etats chrétiens de l'Europe et de l'Amérique, auxquels on donne communément le nom de Capitulations". This position would be affirmed by Allied delegates during the course of the Lausanne negotiations: see, e.g., CRF minutes (2 December 1922), supra note 84, at 470 (the Italian delegate remarking that "the Capitulations were based on treaties"); CRF minutes (6 January 1923), supra note 87, at 516 (the same delegate suggesting that "the Capitulations were nothing more nor less than conventions concluded between the parties thereto in their mutual interest"). For contemporaneous discussion of the question, which was never resolved satisfactorily, see Shih Shun Liu, Extraterritoriality: Its Rise and Its Decline (New York: Columbia University Press, 1925), ch. 9. For more recent consideration, see Viorel Panaite, The Ottoman Law of $W$ ar and Peace: The Ottoman Empire and Tribute Payers (Boulder: East European Monographs / New York: Columbia University Press, 2000) at 239-48; Dariusz Kołodziejczyk, Ottoman-Polish Diplomatic Relations (15 $5^{\text {th }}-18^{\text {th }}$ Century): An Annotated Edition of 'Ahdnames and Other Documents (Leiden: Brill, 2000) at 3-6.

116 Ottoman and Turkish elites had long maintained this position - and had it rejected or ignored by most Western jurists and statesmen. Cf. Feroz Ahmad, “Ottoman Perceptions of the Capitulations 1800-1914” 11 (2000) Journal of Islamic Studies 1. 
Further, even if the capitulations were to be characterized as treaties, instruments that were reciprocally binding rather than unilaterally granted and unilaterally revocable, the circumstances which had given rise to them had been subject to fundamental change. Hence, in this instance, rebus sic stantibus trumped the otherwise general rule of pacta sunt servanda, releasing Turkey from its capitulatory obligations without breaching international public law's basic principles or running foul of its own commitment to international legal order. ${ }^{117}$ Both lines of reasoning, but particularly the latter, were supported by a third, more sweeping argument: if the capitulations were to be situated within their historical contexts, to be approached as legal artefacts intelligible only within the specific temporal and spatial circumstances which had produced them, one could only conclude that they were informed by a conception of personal law that had long since become "an anomaly and an anachronism". ${ }^{118}$ In other words, since "modern legal conceptions" mandated that "each State, in order to be considered as an independent State, must enjoy, within the limits of its frontiers, a complete and full independence", Ankara could "in no wise agree to the re-establishment of the Capitulations, which are in direct conflict with the modern conception of a State and with the principles of public law". ${ }^{119}$ Once again, İsmet was on direct orders from Ankara to stand his ground on this issue - and to walk out of the negotiations should this prove necessary. ${ }^{120}$

It is important that, in making this argument, İsmet took time to note that "no such régime exists in any of the other European countries, not even in Greece and the other Balkan States" ${ }^{\prime 21}$ (though it also bears reminding that extraterritorial regimes of various kinds had been in place in China, Japan, and a number of other non-European states ${ }^{122}$ ). For İsmet, the war to

117 "Memorandum read by the Turkish Delegate", supra note 113, at 478-9. For the doctrinal developments in respect to rebus sic stantibus on which Turkey relied, see L. H. Woolsey, “The Unilateral Termination of Treaties" 20 (1926) AJIL 346 at 349-50.

118 "Memorandum read by the Turkish Delegate", supra note 113, at 479.

119 Ibid.

120 Şimşir, Lozan Telgraflar, supra note 22, at xiv.

121 "Memorandum read by the Turkish Delegate", supra note 113, at 479. See also CRF minutes (6 January 1923), supra note 87, at 511, 514. He would make the same point even more strongly elsewhere: "Not only have the Balkan States been free from all capitulatory restrictions ever since they came into existence, but also no such régime has been set up in the States created after the great war, for instance Poland, Czechoslovakia, Lithuania, Esthonia, \&c. Such a régime does not even exist in Greece.” CRF minutes (28 December 1922), supra note 87, at 491-2.

${ }^{122}$ Indeed, the resemblances were anything but passing. Even as late as the mid-nineteenth century, by which time the "standard of civilization" had begun to circulate widely in international legal circles, some British jurists seem not to have drawn sharp distinctions between the extraterritorial privileges British officials enjoyed over large swaths of Africa and the Pacific and the more formal extraterritorial jurisdiction they were authorized to exercise in Turkey and China. W. Ross Johnston, Sovereignty and Protection: A Study of British Jurisdictional Imperialism in the Late 
which an end was now to be put had been "carried on contrary to all rules"; time after time "the Turkish nation had been completely disarmed and deprived of the resources which international law placed at the disposal of nations desirous of peace". ${ }^{123}$ As "the Turkish people, like all other peoples, was ... obliged to be extremely jealous in all that concerned its existence, independence and rights", ${ }^{124}$ it now sought to make full use of the resources made available to it by modern international law to bolster its sovereign power. A key component in this struggle was the abolition of the capitulations. They had long been regarded by Turkish nationalists as deeply inimical to Turkey's economy and society, running counter to attempts on the part of leading Ottoman diplomats from the late eighteenth century onwards to reframe the Empire's relations with Western powers on the basis of general principles of sovereign equality and reciprocity. ${ }^{125}$ The Committee of Union and Progress - regarded by British authorities in particular as substantially indistinguishable from the Kemalists on hand at Lausanne ${ }^{126}$ - had moved to abrogate them unilaterally in 1914, ${ }^{127}$ at a time when Turkish-Ottoman newspapers encouraged their readers to adopt Weltpolitik with exhortations like "We must now fully realize that our honor and our people's integrity cannot be preserved by those old books of international law, but only by war". ${ }^{128}$ But this had fallen on deaf ears, securing formal recognition from none of the relevant Western states save for Germany and Austria-Hungary. ${ }^{29}$ They were now to be

Nineteenth Century (Durham: Duke University Press, 1973) at 29. For area-specific studies of China and Japan, the closest analogues, see Francis C. Jones, Extraterritoriality in Japan and the Diplomatic Relations Resulting in Its Abolition, 1853-1899 (New Haven: Yale University Press, 1931); Wesley R. Fishel, The End of Extraterritoriality in China (Berkeley: University of California Press, 1952); G. W. Keeton, The Development of Extraterritoriality in China, Two Vols. (New York: Howard Fertig, 1969).

123 TMC minutes (13 December 1922), supra note 13, at 206, 207.

124 Ibid.

${ }^{125}$ For analysis of an important case, see Sinan Kuneralp, "Ottoman Diplomacy and the Controversy over the Interpretation of Article 4 of the Turco-American Treaty of 1830" 31 (2000) Turkish Yearbook of International Relations 7. This was echoed by numerous statements at Lausanne, as in İsmet's declaration that Turkey was "ready to conclude with the Governments concerned treaties of commerce, settlement and extradition, and consular conventions, on the basis of reciprocity and the principles of general international law". "Memorandum read by the Turkish Delegate", supra note 113, at 480 (emphasis mine).

126 G. R. Berridge, Gerald Fitrmaurice (1865-1939), Chief Dragoman of the British Embassy in Turkey (Leiden: Nijhoff, 2007) at 238.

${ }^{127}$ Ottoman Circular Announcing the Abrogation of the Capitulations, 9 September 1914, reproduced in Hurewitz, supra note 37 , at 2 .

128 Quoted in Mustafa Aksakal, The Ottoman Road to War in 1914: The Ottoman Empire and the First World War (Cambridge: Cambridge University Press, 2008) at 21.

129 Nasim Sousa, The Capitulatory Régime of Turkey: Its History, Origin, and Nature (Baltimore: The Johns Hopkins Press, 1933) at 195-6; Norman Bentwich, "The Abrogation of the Turkish Capitulations" 5 (1923) Journal of Comparative Legislation and International Law 182 at 183; Jean-Albert Mazard, Le régime des capitulations en Turquie pendant la guerre de 1914 (Alger: Imprimerie Jean Gaudet, 1923); Ahmed Rechid, "La condition des étrangers dans la République de Turquie" 46 (1933-IV) RCADI 165 at 180-2. Germany had been dangling the carrot of a 
done away with once and for all. That the population exchange would effectively liquidate the "colonies" whose operation the capitulations facilitated made the realization of this goal much easier than would otherwise have been the case.

Neither İsmet nor his interlocutors sought explicitly to link the question of the capitulations and their abolition back to that of the population exchange. Nevertheless, it was evident that the exchange, once concluded, would alter the territorial distribution of powers and peoples in the Near East so thoroughly and irreversibly as to make the continuation of the capitulatory regime pointless, perhaps even impossible. In brief, the commercial "colonies" that European nationals had operated on Ottoman territory with the help of local non-Muslims had diminished dramatically, both in size and in strength, during the preceding years: even the Jews, a British delegate noted with alarm, "members of a non-Moslem community of which the Turkish delegation themselves admit that Turkey has never had reason to complain, are liquidating their property and leaving Smyrna". ${ }^{130}$ As a result, the putative rationale for the capitulations had lost much of its bite: as there were far fewer European merchants in the Empire, so there was far less need for a capitulatory regime.

Allied delegates were willing to recognize the formal abrogation of the capitulations. However, in return for this recognition, they insisted that Turkey undertake a series of legal and administrative reforms. These reforms were to be designed with a view to assuaging the fears of non-Muslims in Turkey, and ought preferably to be coordinated by European jurists. Among other things, the Allies demanded that Turkey staff courts presiding over suits involving foreigners, civil as well as criminal, with foreign judges, "recommended to the Turkish Government by the Permanent International Tribunal [sic] of The Hague" but "appointed by the Turkish Government without any interference on the part of foreign Powers". ${ }^{131}$ The problem was not simply that the "machinery of justice in Turkey" was fundamentally

termination of its capitulations for some time already. Reader Bullard, Large and Loving Privileges: The Capitulations in the Middle East and North Africa (Glasgow: Jackson, Son, \& Co., 1960) at 32; Halil İnalcık, "Imtiyāzāt" in Bernard Lewis et al., eds., The Encyclopaedia of Islam: New Edition, Vol. III (Leiden: Brill, 1986) 1179 at 1188. This was contemporaneous with the Drang nach Osten, a long-term strategy of expansion aimed in part at gaining control over Near Eastern markets that would culminate in the Berlin-to-Baghdad railway project. See, e.g., Şevket Pamuk, The Ottoman Empire and European Capitalism, 1820-1913: Trade, Investment and Production (Cambridge: Cambridge University Press, 1987) at 68-72, 79-81. The scale and depth of German ambition should not be underestimated: between 1888 and 1914, Berlin's share in direct foreign investment in the Ottoman Empire grew from 1\% to 27\%. Donald Quataert, "The Age of Reforms, 1812-1914” in Suraiya Faroqhi et al., eds., An Economic and Social History of the Ottoman Empire, Vol. II (Cambridge: Cambridge University Press, 1994) 759 at 774.

${ }^{130}$ CRF minutes (28 December 1922), supra note 87, at 487 and similarly at 488.

131 Ibid., at 482. 
"defective"; ${ }^{132}$ this much could be resolved through more intensive institution-building and bureaucratic differentiation. Rather, the problem was a deep-structural one: Turkey needed to provide "such guarantees as regards legislation and the administration of justice as will inspire confidence in all those who will be obliged to have recourse thereto". ${ }^{133}$ Existing legal and administrative structures were simply not up to snuff. ${ }^{134}$

None of this was entirely novel. Nor, for that matter, was it entirely limited to the Turkish case. On the contrary, incremental reductions in extraterritorial jurisdiction in other states where capitulatory and unequal treaty regimes of one type or another were operative had nearly always been conditioned on the willingness and ability of local legal and political elites to ensure that contracts were enforced, property rights respected, and, perhaps most importantly, pro-Western reforms undertaken. If Turkey were to be permitted to do away with the capitulations for good - and it should be so permitted, given that even Allied delegates had to confess that Turkey's "aspiration to be free of unwarranted interference" was an essentially "legitimate" one $\mathrm{P}^{135}$ - this would need to come with a condition - namely, that it bind itself to a comprehensive programme of modernization so as to put at ease those foreigners who had "established themselves in Turkey and built up important enterprises there in reliance on the guarantees offered to them by the [capitulatory] treaties". ${ }^{136}$ And just as it had taken some time for comparable programmes to reach maturity in Japan, where, as its own chief delegate put it, "[i]t was only after hard work ..., lasting more than twenty years, that the Powers were able to agree to the Capitulations being brought to an end", ${ }^{137}$ so too would it take a "transitory period"138 for Turkey to suppress Kadijustiz, develop a well-trained and independent judiciary, and promulgate a new batch of secular legal codes, as applicable to non-Muslims as they were to

\footnotetext{
132 Ibid., at 497.

133 CRF minutes (2 December 1922), supra note 84, at 467. A British delegate put this even more forcefully, speaking of the Turks' "duty ... to do their utmost to reassure foreigners". CRF minutes (28 December 1922), supra note 87 , at 487.

134 This was a common assessment at the time, and one which, at its most extreme, was accompanied by sweeping denunciations like the claim that "un Droit Turc n'a jamais existé" and that "l'admission de la Turquie comme membre de la famille des Nations européennes" had therefore been "une déplorable erreur". Charles-Hippolyte Lebeau, Essai sur la justice en Turquie (Paris: Marcel Rivière et Cie., 1924) at 87-8, 89.

${ }_{135}$ CRF minutes (28 December 1922), supra note 87, at 494.

${ }^{136}$ CRF minutes (2 December 1922), supra note 84, at 467.

137 Ibid., at 470; CRF minutes (28 December 1922), supra note 87, at 483. Cf. R. P. Anand, "Family of 'Civilized' States and Japan: A Story of Humiliation, Assimilation, Defiance and Confrontation" in R. P. Anand, Studies in International Law and History: An Asian Perspective (Leiden: Nijhoff, 2004) 24 at 55-6.

${ }^{138}$ CRF minutes (28 December 1922), supra note 87, at 483 and also at 495.
} 
Muslims. ${ }^{139}$ After all, any attempt to nationalize Turkey's economy and society in one fell swoop, to do away with all legal protections that were afforded to nationals of Western states, would undermine investor "confidence" in Turkey's leaders and institutions, doing irreparable damage to the "[g]reat business houses" of Istanbul and Izmir. ${ }^{140}$ And this, as Curzon declared, would have disastrous consequences for the Turks themselves and any attempt to "facilitate the economic restoration of that vigorous people". ${ }^{141}$ The point was really quite simple: "Unless you have a judicial system which makes life possible for the European traders and skilled advisers whom you require and for commercial travellers to go about your country, Turkey will gradually be reduced to the condition, not of a great and prosperous nation, but of a little country lost in the wastes of Asia". ${ }^{142}$

Fearful that demands such as these were simply ruses, makeshift devices with which to preserve, and perhaps even bolster, the substance of the capitulations while doing away with their form, ${ }^{143}$ Ismet would have only so much of this. In the same way that he had been willing to accept only a limited number of minority protection instruments, and even then only so long as their scope of application was restricted to the exceedingly small number of non-Muslims that would remain in Turkey after the exchange, in this context too İsmet insisted that the

${ }^{139}$ Note that the Japanese analogue had particularly deep roots: Cemil Aydın, The Politics of Anti-Westernism in Asia: Visions of World Order in Pan-Islamic and Pan-Asian Thought (New York: Columbia University Press, 2007), ch. 4; Renée Worringer, “'Sick Man of Europe' or 'Japan of the Near East'?: Constructing Ottoman Modernity in the Hamidian and Young Turk Eras" 36 (2004) International Journal of Middle East Studies 207.

${ }_{140}$ Curzon was vigorous on this point: "While they have made sufficient fortunes for themselves, they have contributed very largely to the prosperity and wealth of Turkey. If you decline to consider any revision of your judicial system and stand, as Ismet Pasha did this morning, on an absolute refusal, believe me, you will bring that system down with a crash." CRF minutes (28 December 1922), supra note 87, at 497.

141 Ibid., at 499.

142 Ibid., at 498. Such sentiments were common. Nansen warned that "the flight of the Greek and Armenian populations from Constantinople" would result in the "complete commercial and financial suicide" of the country, stripping it of its "richest asset". Fridtjof Nansen, "Reciprocal Exchange of Racial Minorities between Greece and Turkey", C. 736. N447. 1922, 4 (1923) LNOJ 126 at 129. And Toynbee argued that "if western enterprise is alarmed and outraged by Turkey's new policy towards foreigners ..., it will boycott Turkey and prefer to invest its energies in China, Mexico or any other field where the risks and difficulties are even slightly less great than in the dominions of Angora". Arnold J. Toynbee, "The East after Lausanne" 2 (1923-4) Foreign Affairs 84 at 95. In the short term, these predictions proved largely accurate: the per capita gross national product of the Turkish Republic in 1923, the year of its formal declaration, stood a full $40 \%$ below its pre-First World War levels, a drop explainable only if one takes into account the flight of non-Muslim capital during and after the war and the concomitant loss of commercial skills and contacts. Sevket Pamuk, "Economic Change in Twentieth-Century Turkey: Is the Glass More Than Half Full?" in Reşat Kasaba, ed., The Cambridge History of Turkey, Vol. IV (Cambridge: Cambridge University Press, 2006) 266 at 276.

${ }^{143} \mathrm{CRF}$ minutes (2 December 1922), supra note 84, at 468. As a journalist present at the negotiations would note, the fear was linked closely to Allied strategy: "The Allies deemed it profitable to try to rescue all that could be rescued from the sinking ship of the capitulatory regime.” Ali Naci Karacan, Lozan Konferansi ve İsmet Passa (İstanbul: Maarif Matbaas1, 1943) at 106 (translation mine). 
capitulations' abrogation could not bring with it the institution of any tough-minded supervisory mechanisms. Turkey had "been at work on reorganisation and reform for half a century ..., and ha[d] thus succeeded in creating institutions which are entirely consonant with modern needs". ${ }^{144}$ Under no circumstances could he accept "outside interference" with "the drafting of Turkish internal legislation". ${ }^{145}$ And, crucially, this was a position to which he remained wedded on account of his commitment to press ahead with a compulsory exchange. The "principle of nationalities", however exactly it was to be understood, had to receive "equal application everywhere" if it was to be applied anywhere. "Just as the Greeks established at Marseilles could not reasonably think of creating there an independent Greek State or of annexing it to their mother-country", so too, İsmet argued, "the Greeks or Armenians in Turkey could not legitimately desire the same thing in Turkey". ${ }^{146} \mathrm{He}$ would make certain concessions, such as agreeing to obligate Turkish authorities to enlist the expertise of legal advisers selected from a list drawn up by the Permanent Court of International Justice in some of its courts and also agreeing to allow issues of personal status involving Allied nationals to be decided by courts of Allied states. ${ }^{147}$ But he could go no further than this. The exchange made it possible for "Turkey to have a judicial system" which would "be one and the same for all people in her territory - foreign and Turkish alike". ${ }^{148}$ Physical segregation enabled the Kemalists "to apply in Turkey the system which is in force everywhere else". ${ }^{49}$

In combination, both of these arguments - the one geared toward minority protection, the other concerned with the capitulatory regime - positioned the population exchange, and Turkey's commitment to it, at a distance from the more familiar European practices of the time. In the one case just as much as in the other, İsmet's aim was to bolster Turkey's sovereignty to the greatest extent possible, and to do so in a way that accorded with the distinctive features of the context at hand. Curzon would chide İsmet for being "highly sensitive respecting questions of supervision" 150 on a number of occasions during the negotiations, exasperated at having to respond time and again to "the old argument regarding the infringement of Turkish

\footnotetext{
${ }^{144}$ CRF minutes (6 January 1923), supra note 87, at 510.

145 TMC minutes (14 December 1922), supra note 38, at 226.

146 "Statement read by Ismet Pasha", supra note 65, at 203.

${ }_{147}$ CRF minutes (28 December 1922), supra note 87, at 485; CRF minutes (27 January 1923), in Lausanne Conference, supra note 1 , at 521,523 .

148 Ibid., at 522.

${ }^{149}$ CRF minutes (6 January 1923), supra note 87, at 509 .

150 TMC minutes (14 December 1922), supra note 38, at 219.
} 
sovereignty". 151 "I do implore Ismet Pasha", he declared at one point, "to abandon this argument, to wrap up and put away in a cupboard this phantom of Turkish sovereignty which none of us wants to injure". ${ }^{152}$ İsmet's rejoinder to such comments, as recorded in summary form by the minutes' compiler, was a tellingly blunt one: “The integrity of Turkey had", he declared, "been guaranteed by means of promises from the highest authorities and also by solemn treaties, and yet Turkish sovereignty had repeatedly been violated and Turkey had been dismembered again and again. How could Turkey help having misgivings?" 153 Given the tenor and firmness of this stance, it is not surprising that Turkey should have succeeded in resisting efforts to impose the kind of regime that had been crafted for central and east European states after 1919. What is striking, though, is that it should have been by way of a young and highly unusual mechanism, one whose scope of application was effectively limited to the Near East and whose precise status under international law had yet to be settled, that Turkey should have been transformed into a national state. Indeed, so keen were many at Lausanne to limit the reach of this mechanism that Child, lead American delegate, would explicitly raise the thorny question of the exchange's prospective precedential force under international law: "We believe", he warned far-sightedly, "that new precedents which tend to establish the right of nations to expel large bodies of their citizens to become burdens upon other nations must be carefully considered before countenance is given them, lest a new and unwholesome principle find foothold to vex international law and justice". ${ }^{154}$

\section{Two Tensions Enshrined}

The package of international legal instruments ultimately produced by the Conference of Lausanne would reflect the tensions inherent in these negotiations - that concerning the place of ethno-nationalism in the exchange's design and execution, and that relating to the regionally specific character of the exchange mechanism. The Convention concerning the Exchange of Greek and Turkish Populations (and a related agreement on the restitution of interned civilians and exchange of prisoners of war) would be annexed to the Peace Treaty when it and fourteen

\footnotetext{
${ }^{151}$ CRF minutes (28 December 1922), supra note 87, at 496.

152 Ibid.

153 TMC minutes (14 December 1922), supra note 38, at 219.

154 TMC minutes (12 December 1922), supra note 1, at 187.
} 
other instruments were finally signed in July 1923 to form the complete peace settlement with Turkey. The fact that it had been signed in January, some six months prior to all but the restitution and prisoner exchange agreement, led many commentators, then as well as later, to speculate that it had been regarded by diplomats at Lausanne as a prerequisite for a final and lasting peace. ${ }^{155}$

In line with Ottoman tradition, the Peace Treaty contained no stipulation that Turkey recognize Kurds, Arabs, or any of its other non-Turkish Muslim communities as national minorities. Nor did it make any allowance for Kurdish autonomy or an Armenian "national home", as the Treaty of Sèvres had. The Turks had remained firm in the face of half-hearted Allied demands that such "homes" be created in Asia Minor for Armenians and Assyrians, meeting "all the questions put to them" on these matters "with an absolute and clear refusal". 156 Reflecting this, the Peace Treaty restricted the application of minority status to those nonMuslim groups which had traditionally commanded dominant positions within the millet system: the Greek, Armenian, and Jewish communities. ${ }^{157}$ Article 39 was the touchstone here, requiring that Turkey supply its non-Muslim citizens - a reference understood to be limited to these three communities - with the same civil and political entitlements as its Muslim citizens. This and a number of other, issue-specific provisions of the treaty - the already mentioned Articles 37 through $44^{158}$ - fixed the parameters within which Turkey would henceforth address minority protection: in order to ensure observance of the general right to equality enshrined in Article 39, it was provided that Greeks, Armenians, and Jews could practise their religion freely (Article 38), make free and full use of their native tongues (Article 39), maintain educational and charitable foundations without undue state interference (Article 40), and so on. ${ }^{159}$ Minority protection was thus introduced into Turkey. But it came in a highly attenuated and problematic

\footnotetext{
155 Baskin Oran, "The Story of Those who Stayed: Lessons from Articles 1 and 2 of the 1923 Convention" in Renée Hirschon, ed., Crossing the Aegean: An Appraisal of the 1923 Compulsory Population Exchange between Greece and Turkey (New York: Berghahn, 2003) 97 at 97.

156 TMC minutes (9 January 1923), supra note 9, at 308. As Grew would observe, "[t] here is no subject upon which the Turks are more fixed in obstinacy". Turbulent Era, supra note 12, at 531. This stance was naturally opposed by an increasingly vocal Armenian diaspora: see the documents reprinted in the American Committee Opposed to the Lausanne Treaty's The Lausanne Treaty, Turkey and Armenia (New York: n. p., 1926).

${ }^{157}$ Curson glossed the decision with apprehension: "The sub-commission originally pressed for the inclusion of all racial minorities, Moslem and non-Moslem - for instance, the Kurds, Circassians and Arabs. The Turkish delegation insisted that these minorities required no protection, and were quite satisfied with their lot under Turkish rule. I hope that this will be the case". TMC minutes (9 January 1923), supra note 9, at 296.

158 Treaty of Peace, signed at Lausanne, July 24, 1923, 28 LNTS 11 at 31-7.

${ }^{159}$ Ibid., at 31-3.
} 
form. Not only was its application restricted to demographically negligible groups of nonMuslims, thereby underscoring the primacy of a specifically Turkish-Muslim ethnos, but this restricted application followed directly from the population exchange, which made it factually impossible and normatively implausible for a genuinely robust minority protection regime to be put into effect.

Importantly, Turkey could comply with these treaty obligations if and only if it promulgated newer, more "modern" legal codes (which, in turn, would provide some measure of "compensation" to the Western powers for the capitulations' abolition). ${ }^{160}$ This much the Kemalists were prepared to undertake, as it coincided with their own commitment to part with Ottoman traditions of legal pluralism and adopt many of the West's legal and administrative innovations so as to "catch up" with the exemplars of "contemporary civilization". ${ }^{161}$ So much so that they agreed to permit "a number of European legal counsellors" selected from a list drafted by the Permanent Court to be posted for a certain period in Istanbul and Izmir for the sake of participating in legislative commissions, observing the operation of Turkish courts, and preparing reports for the Turkish minister of justice when needed - all "with a view to the institution of such reforms as may be rendered advisable by the development of manners and civilization". ${ }^{162}$ What the Kemalists were not willing to do, though, was to allow the most visible elements of the extraterritorial consular regime enshrined in the capitulations to be preserved.

To be sure, some of the Lausanne settlement's provisions betrayed the continuing influence of the exploitative relations the capitulations had made possible. In addition to the European legal advisors, there was, for instance, the apportionment of the Ottoman public debt, ${ }^{163}$ the limitation of tariffs and related measures for a number of years, ${ }^{164}$ and the placing of matters of personal status and family law involving non-Muslim nationals of the Allied Powers within the jurisdiction of their respective countries' courts. ${ }^{165}$ However, while certainly not

\footnotetext{
160 A quid pro quo analyzed well in Edgar Turlington, "The Settlement of Lausanne” 18 (1924) AJIL 696 at 697-9.

161 See, e.g., Mustafa Kemal, “Ankara Hukuk Fakültesinin Açllısında (5.XI.1925)”, in Taha Parla, ed., Türkiye'de Siyasal Kültürün Resmî Kaynaklar, Vol. III (İstanbul: İletişim, 1992) 292 at 293.

162 Declaration relating to the Administration of Justice, signed at Lausanne, July 24, 1923, 36 LNTS 161 at 163. The four men to be selected as advisors were Georges Sauser-Hall (Switzerland), Goeman Borgesius (Netherlands), Fritz Sterzel (Sweden), and one Follache (Spain) - two judges and two law professors.

${ }^{163}$ Lausanne Peace Treaty, supra note 158, Arts. 46-57, at 37-51.

${ }^{164}$ Commercial Convention, signed at Lausanne, July 24, 1923, 28 LNTS 171.

165 Convention concerning the Exchange of Greek and Turkish Populations, and Protocol, signed at Lausanne, January 30, 1923, 32 LNTS 75, Art. 16, at 85. For a concise breakdown of these and related concessions, see Philip
} 
negligible, ${ }^{166}$ none of this alters the fact that the most noticeable features of the regime were eliminated by Article 28 of the Lausanne Peace Treaty, which formalized "the complete abolition of the Capitulations in Turkey in every respect". ${ }^{167}$ If the capacity to enact and enforce legislation freely is, as the Permanent Court would observe in a few years' time, "one of the most obvious forms of the exercise of sovereign power", 168 the abolition of the capitulations tied closely to the drive towards ethnic homogeneity and territorial sovereignty that underpinned the population exchange - marked a key moment in the augmentation of Turkey's capacity to exercise this power. Indeed, as Manley Hudson noted, it was foundational to Turkish elites' desire to achieve "two main objectives" - "to create a Turkish nation of Turkish people living on Turkish territory, and to win for this nation a place of equality among the nations of the Western World". ${ }^{169}$

The text of the Convention of Lausanne is revealing. Its first two articles called for the institution of a compulsory exchange between "Turkish nationals of the Greek Orthodox religion" and "Greek nationals of the Moslem religion", but also allowed exceptions to this rule in the case of Muslims inhabiting western Thrace and Greeks established in Istanbul (and, when read in conjunction with Article 14 of the Lausanne Peace Treaty, two Aegean islands that had been assigned to Turkey). ${ }^{170}$ By any account, this was a rather murky and untidy attempt to align ethnicity with territory throughout the Near East: it was often unclear which of the two state parties ought to be assigned control over a given community, these being ill-defined, ${ }^{171}$ and the

Marshall Brown, "From Sèvres to Lausanne" 18 (1924) AJIL 113 at 114; and similarly Philip Marshall Brown, "The Capitulations" 1 (1922-3) Foreign Affairs 71 at 79-81.

166 Indeed, it has been maintained that, despite having secured its political independence, Turkey was in some respects “one of the few countries where 'Open Door' conditions actually held", at least for a limited period after 1923. Çağlar Keyder, The Definition of a Peripheral Economy: Turkey 1923-1929 (Cambridge: Cambridge University Press / Éditions de la maison des sciences de l'homme, 1981) at 9 and 69-71 for details. On these short-term limitations on protectionism, see Korkut Boratav, Türkiye'de Devletçilik, 2nd Ed. (Ankara: İmge, 2006) at 33-5.

${ }^{167}$ Lausanne Peace Treaty, supra note 158, at 27.

${ }^{168}$ Legal Status of Eastern Greenland (Denmark v. Norway) PCIJ Rep. Series A/B No. 53 (1933) at 48.

169 Manley O. Hudson, "Law Reform in Turkey" 13 (1927) American Bar Association Journal 5 at 5.

170 Convention of Lausanne, supra note 165, at 77; Lausanne Peace Treaty, supra note 158, at 17. The islands in question were Imbros/Gökçeada and Tenedos/Bozcaada.

171 For instance, Turkish-speaking Orthodox Christians inhabiting central Anatolia (Karamanlides in Greek, Karamanllar in Turkish) were subject to the exchange procedure - despite the fact that they were often inclined to self-identify as "Turks" and were opposed to the move. See Richard Clogg, "A Millet Within a Millet: The Karamanlides" in Dimitri Gondicas and Charles Issawi, eds., Ottoman Greeks in the Age of Nationalism: Politics, Economy, and Society in the Nineteenth Century (Princeton: Darwin Press, 1999) 115 at 115 and 131-2; Renk Özdemir, "Borders of Belonging in the 'Exchanged' Generations of Karamanlis" in Ahmet İçduygu and Kemal Kirişci, eds., Land of Diverse Migrations: Challenges of Emigration and Immigration in Turkey (İstanbul: İstanbul Bilgi University Press, 2009) 29. 
availability of exceptions, however limited, allowed for the creation of dangerously porous and vulnerable enclaves. Articles 8 through 17 explained that the exchange procedure was to be coordinated by a mixed commission, an institution funded by all of "the States concerned". ${ }^{172}$ Article 7 stipulated that those subject to the exchange would be stripped of their previous citizenship and transformed into nationals of the state to which they had been transferred immediately upon arrival. ${ }^{173}$ This was an automatic process of re-nationalization, and, as such, a far cry from other ways of dealing with problems of citizenship arising from situations of state succession. For instance, no plebiscite - a mechanism of limited application even in Europe ${ }^{174}-$ was organized for the resolution of conflict between Greece and Turkey. Turkey pressed for plebiscites in western Thrace, and also in the oil-rich former Ottoman province of Mosul, but both requests were denied. ${ }^{175}$ The only exception was the ethnically mixed border province of Alexandretta (Hatay), incorporated into France's Syrian mandate after 1923 but annexed by Turkey after a controversial plebiscite in $1938 .{ }^{176}$ The right of option, enabling individuals to choose their citizenship after state dissolution, had been popularized in post-Versailles Europe, and enjoyed some limited traction in post-Ottoman territories: Articles 31 through 35 of the

\footnotetext{
172 Convention of Lausanne, supra note 165, at 79-85.

173 Ibid., at 79.

${ }^{174}$ Sarah Wambaugh, Plebiscites since the World War, with a Collection of Official Documents, Vol. I (Washington: Carnegie Endowment for International Peace, 1933) at 42 (noting that "the Allies avoided a plebiscite in every region of first importance save that of Upper Silesia, and that when they resorted to a plebiscite it was as a method of compromise, to escape from a dilemma rather than as a deliberate choice").

175 Mosul was the more complex of the two, not having been resolved at Lausanne and having led to protracted negotiations between Britain and Turkey thereafter. A 1924 investigation conducted by a League expeditionary force resulted in a report underscoring the logistical challenges of holding a plebiscite and the inevitability of placing Mosul under the same mandate as Baghdad and Basra. Though resistance within Turkey was strong, the Kemalists eventually agreed to recognize Britain's mandate south of the boundary the expedition had recommended (the so-called "Brussels line") in exchange for a 10\% per annum cut of Iraq's oil revenues. For the PCIJ's opinion on the League Council's powers in the matter, see Interpretation of Article 3, Paragraph 2, of the Treaty of Lausanne (Frontier between Turkey and Iraq), Advisory Opinion, PCIJ Rep. Series B No. 12 (1925). For the plebiscitary question, see Wambaugh, supra note 174, at 538-44. For analysis of the negotiations, see Quincy Wright, "The Mosul Dispute" 20 (1926) AJIL 453; Berriedale Keith, "The League of Nations and Mosul" 8 (1926) Journal of Comparative Legislation and International Law 38; Abdul-Malik Salim Al-Zaibag, "The Mosul Boundary Question", M.A. thesis, Tufts University (1948), esp. chs. 5, 6; David Cuthell, "A Kemalist Gambit: A View of the Political Negotiations in the Determination of the Turkish-Iraqi Border” in Reeva Spector Simon and Eleanor H. Tejirian, eds., The Creation of Iraq, 1914-1921 (New York: Columbia University Press, 2004) 80; Sarah D. Shields, Fezzes in the River: Identity Politics and European Diplomacy in the Middle East on the Eve of World War II (Oxford: Oxford University Press, 2011).

176 Significantly, the evidence suggests that Turkey's successful annexation owed more to French reluctance to become embroiled in another Levantine conflict than to the actual number of votes cast. For details, see Majid Khadduri, "The Alexandretta Dispute" 39 (1945) AJIL 406; Ahmet Özgiray, "Turco-French Relations and the Syrian Border Question (1924-1930)" in Daniel Panzac, ed., Histoire économique et sociale de l'Empire ottoman et de la Turquie (1326-1960). Actes du sixième congres international tenu à Aix-en-Provence du 1er au 4 juillet 1992 (Leuven: Peeters, 1995) 671.
} 
Lausanne Peace Treaty provided a two-year right of option for certain persons resident in territories detached from Turkey, conditioned on the consent of the receiving state. ${ }^{177}$ But once again, expulsions and other movements had already segregated the region's constituent communities to a significant degree, and were to segregate them even further with the completion of the compulsory population exchange between Greece and Turkey. This diluted the relevance and efficacy of any residual right of option that was made available. ${ }^{178}$ Even more to the point, no right of option was deployed to resolve the Greek-Turkish conflict itself; in this case, nothing less than the compulsory exchange was deemed enough.

All in all, then, the Lausanne settlement reflected the vicissitudes of the negotiations which made it possible. The population exchange, as crafted at Lausanne, offered a unique method of resolving conflict, one which was driven not only by ethno-nationalism but also by its supposed opposite - a technocratic effort to bring increasingly elaborate means of legal administration to bear upon a given territory and population. The exchange was also positioned at a considerable distance from minority protection and related intra-European mechanisms of nation-building, thereby underscoring its roots in a specific region with a specific set of embedded legal and political practices.

${ }^{177}$ Lausanne Peace Treaty, supra note 158, at 29-31.

178 Cf. Norman Bentwich, "Nationality in Mandated Territories Detached from Turkey" 7 (1926) BYIL 97 at 98. 


\section{CHAPTER IV.}

\section{Litigating the Exchange before the World Court:}

\section{Humanitarianism and the Mobilization of an International Legal Community}

For Europeans, the Ottoman Empire had always been an object of mixed emotions - fear, revulsion, fascination, and others. In the nineteenth century, though, a comparatively new cluster of sentiments, first and foremost the compulsion to partition and salvage, began to gain prominence, displacing gradually and by increments the formerly predominant fascination with the sultan's court and wealth. The background narrative is a familiar one: the emergence of new forms of legal and administrative rationalization combined with capital accumulated from the colonization and exploitation of the extra-European world to generate increasingly sophisticated technologies of warfare and statecraft in northwestern Europe, strengthening Europeans' sense of cultural superiority over non-Europeans. In the case of the Ottomans, this process began to gain momentum in the mid-eighteenth century, when Mediterranean power dynamics, already realigned through shifting patterns of trade and conflict, entered a period of systemic overhaul. At first, the Ottomans managed to negotiate this new terrain through a combination of diplomacy and patch-and-mend reform. When they could not play one great power off another, they tried to stave off outright partition by marshalling their residual military strength. Such an approach - standard for the Ottomans throughout the long nineteenth century - obviously had its risks. And it would come to an abrupt end with the First World War. Thenceforth, the Empire would, it was widely believed, have to be reconstructed and redeemed - or, more precisely, reconstructed in order to be redeemed.

The explosion of interest in the Near East that one encounters among humanitarians after 1914, particularly after the Armenian genocide was formally underway in early 1915, owed much to the fact that Turkey had by that point become both the agent and victim of an unprecedentedly high level of volatility. Humanitarian intervention's doctrinal crystallization in the nineteenth century had been closely related to great power involvement in the Near East. “L'origine et le développement de l'idée d'intervention d'humanité paraissent liés dans une

certaine mesure à l'histoire de la question d'Orient", wrote Antoine Rougier in an influential study, adding “c'est au fur et à mesure des excès commis par le gouvernement turc que la 
diplomatie tente de cette idée de timides applications et que la doctrine se précise". After 1914, wholesale, often indiscriminate destruction and displacement, both of persons and of properties, transformed the Near East into a cause célèbre for professional humanitarians. Almost overnight, the region was turned into something of a testing-ground for new policies of legal reconstruction being developed by Western governments, the League of Nations, and the various charitable organizations they either supported or tolerated. It was Turkey, argued a Cambridge lawyer in 1924, that was "[t] he particular case thinly concealed behind most of the generalities concerning humanitarian intervention", observing that "the discussion of humanitarian intervention has become so bound up with atrocities in the Near East that it may be doubted whether it would have been quite so freely admitted by its supporters in the case of barbarities incidental to internal disputes in any other State". ${ }^{2}$ Firm, precise borders were now to be fixed and patrolled by an international legal community dedicated to securing perpetual peace through the sublimation of nationalism. And this was to be achieved through the strategic exercise of a humanitarian power that was increasingly embodied in international organizations. ${ }^{3}$

This chapter considers this drive to reconstruct the Near East by examining the Permanent Court of International Justice's 1925 opinion in Exchange of Greek and Turkish Populations from the perspective of wide-ranging disputes concerning the place of ethnicity and religion in the exchange process. I first contextualize these disputes by discussing the various organizations involved in the Near East's reconstruction during the execution of the exchange. I do so by way of an historical investigation into their provenance in the Anglo-American missionary movement, paying particular attention to this movement's close engagement with the Near East, a key locus of its activities from the early nineteenth century onwards. I then move on to discuss the Permanent Court's judgment on its own terms. Through close analysis of the way in which it broached the issue of "les établis", Greek residents of Istanbul exempted from the exchange, I demonstrate that the Court drew a sharp distinction between domestic and international law, bypassing Turkish concerns about the exchange's implementation so as to

\footnotetext{
1 Antoine Rougier "La théorie de l'intervention d'humanité" 12 (1910) RGDIP 468 at 472.

2 P. H. Winfield, "The Grounds of Intervention in International Law" 5 (1924) BYIL 149 at 161-2. Such sentiments were exceedingly common at the time; see, e.g., André Mandelstam, "La protection des minorités" 1 (1923-I) RCADI 363 at 373, 382 (arguing that "[1]a cause principale de l'intervention constante des grandes Puissances en Turquie a été dans le caractère despotique de l'Empire ottoman" and that "les Puissances se pénétraient peu à peu de la conviction que le respect du droit humain ne devait pas être imposé aux seuls Turcs"). ${ }^{3}$ Cf. Samuel Moyn, The Last Utopia: Human Rights in History (Cambridge, MA: Harvard University Press, 2010) at 220.
} 
shield as much of Istanbul's Greek enclave as possible from the exchange. In doing so, the Court contained ethno-nationalism in a structurally homologous way to that whereby the humanitarians who poured into the Near East before and during the exchange sought to "civilize" it. If the latter brought the full weight of their political and economic power to bear upon the task of curbing the causes and consequences of a semi-peripheral conflict with serious international repercussions, the former circumvented Turkish law in interpreting the Convention of Lausanne with a view to maximizing the treaty-based rights of Istanbul's Greeks.

\section{"To Bring upon Turkey the Pressure of Moral Force"}

Western philanthropic interest in the Near East, a notable feature of European-Ottoman relations for decades, grew strong during and particularly after the First World War, with humanitarian organizations linked to missionary movements responding regularly to the turmoil into which the region was plunged. Re-entering the Near East in the wake of the Paris Peace Conference, these organizations often aimed to effect a systemic transfiguration of Turkey into a steadfast member of the "family of civilized nations". By parcelling the Ottoman Empire along ethno-confessional lines, with Greeks and Turks being "unmixed", a "national home" being set up for Armenians, and regional autonomy qua proto-independence being extended to Kurds, the Near East might be brought in line with prevailing norms of national statehood, which, in turn, would go some way to anchor the region as a whole in an international legal order that was itself undergoing systemic reconfiguration. As noted by James Barton, the leading representative of Near East Relief, a US-based philanthropic organization founded in 1915 to assist Armenians fleeing genocide, ${ }^{4}$ facilitating Turkey's transition from an empire to a national state governing itself under international law would "allow the nations to bring upon Turkey the pressure of moral force", compelling "Turkey to set her house in order, to revise her court procedure, the relation of the official classes to the minority populations, her educational system, her moral standards, so that she may become a worthy member of the great

\footnotetext{
4 The best source of information remains James L. Barton, Story of Near East Relief (1915-1930): An Interpretation (New York: Macmillan, 1930). See also the documents in James L. Barton, "Turkish Atrocities": Statements of American Missionaries on the Destruction of Christian Communities in Ottoman Turkey, 1915-1917 (Ann Arbor, MI: Gomidas Institute, 1998).
} 
sisterhood". 5 Indeed, Barton stressed, the Lausanne negotiations had made this transition something of a necessity:

"While many may recoil from having a country with the reputation of Turkey come into the sisterhood of nations, nevertheless the principle seems to have been accepted at Lausanne, and we may expect that after the treaties have been signed Turkey will be admitted into that great group of nations banded together for perpetual peace and good order. ... Turkey would hesitate to perpetuate new atrocities if she knew that at the next session of the Council of the League of Nations she was to be arraigned for the act."

Barton was no lone figure. Institutionally, he had served as a secretary of the American Board of Commissioners for Foreign Missions, an umbrella organization for a disciplined and exceedingly resourceful Protestant missionary movement on which even British diplomats stationed in the Near East relied for up-to-date information. ${ }^{7}$ And Near East Relief - an organization which still (as the Near East Foundation) touts itself as the "first true international development organization", having "pioneered international humanitarian assistance" and much of the accompanying culture industry ${ }^{8}$ - was the largest humanitarian organization operating in the region at the time of the population exchange. 'As for Barton's views, they were anything but the whims of an eccentric, being broadly consonant with those shared by a wide range of officials associated with the humanitarian avant-garde of the 1910s and 1920s. During the Balkan Wars, Anglican clergy frequently called for the eradication of "the immoral system of unmitigated force applied by the Turks in their travesty of government"10 - a development made all the more remarkable by the fact that the British establishment to which the Church of

\footnotetext{
${ }^{5}$ James L. Barton, "A Program for the Near East" (1923) 108 Annals of the American Academy of Political and Social Science 153 at $158-9$.

${ }^{6}$ Ibid.

${ }^{7}$ G. R. Berridge, British Diplomacy in Turkey, 1583 to the Present: A Study in the Evolution of the Resident Embassy (Leiden: Nijhoff, 2009) at 135.

${ }^{8}$ Near East Foundation, "Near East Foundation Celebrates 90th Year; First U.S. International Development Organization; Pioneer of American Philanthropy Abroad", available online at: http://www.neareast.org/images/u ploads /90thanniv 1.pdf (last accessed 6 April 2011) at 1, 2. Such claims would not, of course, go uncontested; see, e.g., Harald Fischer-Tiné, "Global Civil Society and the Forces of Empire: The Salvation Army, British Imperialism, and the 'Prehistory' of NGOs (ca. 1880-1920)" in Sebastian Conrad and Dominic Sachsenmaier, eds., Competing Visions of World Order: Global Moments and Movements, 1880s-1930s (New York: Palgrave Macmillan, 2007) 29 at 52.

${ }^{9}$ Dzovinar Kévonian, Réfugiés et diplomatie bumanitaire. Les acteurs européens et la scène proche-orientale pendant l'entre-deuxguerres (Paris: Publications de la Sorbonne, 2004) at $287 \mathrm{ff}$.

${ }^{10}$ Quoted in Albert Marrin, The Last Crusade: The Church of England in the First World War (Durham: Duke University Press, 1974) at 239.
} 
England was so essential had often maintained a certain distance from missionary philanthropy, ${ }^{11}$ and that it was only toward the end of the First World War that Protestant missionaries began to have recourse to quasi-legal notions of "supranationality" to combat internment and repatriation. ${ }^{12}$ For their part, the governmental authorities with which missionaries dealt generally hesitated to adopt explicitly theological language only when such action proved politically inexpedient, as when the British, fearing rebellion in India, famously vetoed a Franco-Russian draft of a diplomatic protest against the deportation and massacre of Armenians that spoke of "crimes against Christendom" (the wording was subsequently altered to "crimes against civilization and humanity" and eventually found its way into international law on that basis). ${ }^{13}$

Barton and his colleagues pressed hard to realize their vision of a reinvigorated Near East, supplying assistance to the region's refugees so as to ensure its inclusion in a reformed international legal order. From 1919 to 1923, Near East Relief was reported to have spent something in the vicinity of forty million US dollars in Turkey. ${ }^{14}$ The lead American delegate at the Conference of Lausanne quoted an even higher figure for his government's relief expenditures - seventy-five million through one committee alone - before remarking that the United States demanded "no return for this expenditure unless it be assurance that this conference ... will find means to wipe away at once the causes for this waste of human life and

\footnotetext{
11 Susan Thorne, “The Conversion of Englishmen and the Conversion of the World Inseparable': Missionary Imperialism and the Language of Class in Early Industrial Britain” in Frederick Cooper and Ann Laura Stoler, eds., Tensions of Empire: Colonial Cultures in a Bourgeois World (Berkeley: University of California Press, 1997) 238 at 243-6.

12 An October 1919 issue of the International Review of Missions appears to be the first time the term appears in English. Though lawyers would struggle for years to develop a precise definition, "supranationality" soon came to serve as a quasi-legal moniker for missionary work. John Stuart, "Beyond Sovereignty?: Protestant Missions, Empire and Transnationalism, 1890-1950" in Kevin Grant, Philippa Levine, and Frank Trentmann, eds., Beyond Sovereignty: Britain, Empire and Transnationalism, c. 1880-1950 (Houndsmills: Palgrave Macmillan, 2007) 103 at 109.

13 The expression was not used in the post-First World War treaties, the otherwise ambitious Treaty of Sèvres included, partly because US representatives to the 1919 Commission on the Responsibility of the Authors of the War and on Enforcement of Penalties were committed to the view that " $t]$ here is no fixed and universal standard of humanity", and that this precludes the "laws and principles of humanity ... from consideration in a court of justice, especially one charged with the administration of criminal law". Commission on the Responsibility of the Authors of the War and on Enforcement of Penalties, Report Presented to the Preliminary Peace Conference, reproduced in 14 (1920) AJIL Sup. 95 at 134, 144. While the notion of "crimes against humanity" would retain its fascination for many international lawyers, it was not until after the Second World War that it would begin to acquire an exact legal definition. See Egon Schwelb, "Crimes against Humanity" 23 (1946) BYIL 178 at 180-3; David Matas, "Prosecuting Crimes against Humanity: The Lessons of World War I" 13 (1989-90) Fordham International Law Journal 86 at 87-92; M. Cherif Bassiouni, Crimes against Humanity in International Criminal Law, 2nd Rev. Ed. (The Hague: Kluwer, 1999) at 62-9. See further Sévane Garibian, "From the 1915 Allied Joint Declaration to the 1920 Treaty of Sèvres: Back to an International Criminal Law in Progress" 52 (2010) Armenian Review 86.

14 Leland James Gordon, American Relations with Turkey 1830-1930: An Economic Interpretation (Philadelphia: University of Pennsylvania Press, 1932) at 246.
} 
human suffering". ${ }^{15}$ This bolstered the colossal loans the great powers and League of Nations had already made available to Greece, partly through the establishment of the Greek Refugee Settlement Commission, an organization entrusted with the task of assisting the mixed commission foreseen by the Convention of Lausanne with its resettlement and compensation efforts. $^{16}$

The project Barton and other humanitarians launched in the Near East was an ambitious one. A Near East Relief official was the first American national not in the direct employment of the US government to receive accreditation from Kemal's parliament. ${ }^{17}$ Though missionaries had been at work in the region for nearly a century, Near East Relief brought a level of financial support and organizational sophistication that could not be matched, quickly absorbing many existing groups into its fold. ${ }^{18}$ An agreement being concluded between Near East Relief and the nationalist government shortly thereafter, ${ }^{19}$ the formal exchange would unfold under its watch, with its personnel and affiliates assuming much of the responsibility for undertaking the nuts-and-bolts work of resettlement and aid provision on the ground. ${ }^{20}$ Indeed, as Barton pointed out proudly, "[t]he first transfer of Moslem and Greek populations under the

15 TMC minutes (12 December 1922), in Lausanne Conference on Near Eastern Affairs (1922-1923): Records of Proceedings and Draft Terms of Peace, Cmd. 1814 (London: His Majesty's Stationery Office, 1923) at 173, 185. The Ankara government would devote only a fraction of the amount that its Athenian counterpart allotted to the settlement of refugees. For details, see Mihri Belli, Türkiye-Yunanistan Nüfus Mübadelesi: Ekonomike Açıan Bir Bakıs, tr. Müfide Pekin (İstanbul: Belge, 2006) at 88, 94-5; John A. Petropulos, “The Compulsory Exchange of Populations: GreekTurkish Peacemaking, 1922-1930” 2 (1976) Byzantine and Modern Greek. Studies 135 at 156.

${ }^{16}$ For the agreement setting up the Greek Refugee Settlement Commission, see the Declaration relating to the Settlement of Refugees in Greece and the Creation for this Purpose of a Refugees Settlement Commission, signed on behalf of Great Britain, France and Italy, at Geneva, September 29, 1923, 20 LNTS 41. Despite the size of the loans, Greek authorities dragged their feet, leading many refugees to join the Greek Communist Party. Venizelos' decision in 1930 to lay aside outstanding claims relating to properties lost or abandoned during the exchange only strengthened these tendencies; once staunch supporters of Venizelos, refugees came to form the backbone of the country's syndicalist left. Onur Yıldırım, "The 1923 Population Exchange, Refugees and National Historiographies in Greece and Turkey" 40 (2006) East European Quarterly 45 at 51; Triadafilos Triadafilopoulos, "The Political Consequences of Forced Population Transfers: Refugee Incorporation in Greece and West Germany" in Rainer Ohliger, Karen Schönwälder, and Triadafilos Triadafilopoulos, eds., European Encounters: Migrants, Migration, and European Societies since 1945 (Aldershot: Ashgate, 2003) 99 at 107-10, 115. For a full-length study, see Renée Hirschon, Heirs of the Greek Catastrophe: The Social Life of Asia Minor Refugees in Piraeus (Oxford: Clarendon Press, 1989).

17 This national, one Annie P. Allen, "familiar both with the language and the people" as Barton put it, quickly "won the confidence and the respect of official Angora". Story, supra note 4, at 142. See further Kévonian, supra note 9, at 292.

18 An illustrative example being female Congregrationalist missionaries from New England, nearly all of whom would come to join Near East Relief's ranks by the 1930s. Constantia Kiskira, “Evangelising' the Orient; New England Womanhood in the Ottoman Empire, 1830-1930" 16 (1998) Archivum Ottomanicum 279 at 282.

${ }^{19}$ For the full text, see Barton, Story, supra note 4, at 149-50.

${ }^{20}$ Ibid., at 154. 
terms of the Treaty of Lausanne was made under the authority and supervision of the Near East Relief'. ${ }^{21}$ Neither Greece nor Turkey opposed this. Though Near East Relief moved aggressively to position itself at the head of the exchange operation, both states supported its involvement; they even asked it to begin implementing the exchange before the mixed commission had been assembled. ${ }^{22}$

The specifically legal implications were equally far-reaching. With the help of Near East Relief and similar organizations, and with the active support and participation of Turkish nationalists, the exchange was to lay the groundwork for a national state that would (or, more precisely, would claim to) rupture the existing legal order radically and irrevocably. An ostensibly ossified Shari'a was to be replaced with a set of laicist codes adapted from Swiss, Italian, French, and German originals (for civil, criminal, administrative, and commercial law respectively), a new batch of legal and administrative institutions fortified with competent personnel, and excessively discretionary decision-making supplanted once and for all by the work of an independent and well-trained judiciary. In the words of a Swiss jurist appointed as legal adviser to the young Turkish Republic in Lausanne's wake, the substantive outcome of this process was a Turkey which had "complètement transformé son armature juridique" by the time the final years of the 1920s rolled around. "23 "Il n'y a pas d'autre exemple dans l'histoire", he proclaimed, "d'une transformation aussi radicale et aussi foudroyante" - a rather hyperbolic statement made all the more striking by the fact that this "transformation" was ultimately not effected through mandatory rule. ${ }^{24}$

That this project was premised on a parochial, and somewhat circular, understanding of nation-building is clear: though formalized judicial procedures and constitutionally entrenched separations of powers of the sort that humanitarians had in mind were frequently outgrowths of specifically northwest European experiences, they were believed to lend themselves to transplantation, to the Near East and elsewhere, without great difficulty. Indeed, if the "good governance" touted by many of today's think tanks "takes institutions that are the products of a particular history and trajectory of political development and posits them as the principal

\footnotetext{
${ }^{21}$ Ibid., at 165 .

22 Ibid., at 166-7.

23 Georges Sauser-Hall, "La réception des droits européens en Turquie" in Recueil de travaux publié à l'occasion de l'Assemblée de la Société suisse des juristes à Genève, du 4 au 6 septembre 1938 (Genève: Imprimerie Albert Kundig, 1938) 323 at 345.

24 Ibid.
} 
solutions to undesirable political dynamics and outcomes", 25 the liberal internationalism underpinning the missionary humanitarianism of organizations like Near East Relief fell prey to much the same delusion. Not entirely unlike many of today's militants of "democracy promotion", ${ }^{26}$ a set of norms and structures deriving from a spatially and temporally circumscribed set of circumstances found themselves elevated to the status of summa bonaapplicable across time and space, as fitting for the nomads of central Anatolia then as they had been for the burghers of Berlin a century earlier. Organized, legally sanctioned population exchanges were novel, but the trappings of national statehood they were intended to generate were not.

Much of the pathos and narcissism of the missionary movement operating in the late Ottoman Empire could not, of course, be duplicated under the conditions of the interbellum. But the orientalism on which many missionaries had relied continued to thrive in this atmosphere, albeit only after having been finessed by a new batch of international organizations. Pace Grewe, for whom the concept of civilization had effectively disappeared by $1919,{ }^{27}$ the civilizing mission was alive and well. One need only think here of Article 22 of the League of Nations Covenant, which famously spoke of a "sacred trust of civilization" linking mandatory powers to those "peoples not yet able to stand by themselves under the strenuous conditions of the modern world", 28 or of the "standard of civilization", that fluctuating nineteenth-century criterion for ranking states and regions which fed post-First World War attempts to grade territories detached from the German and Ottoman empires as " $\mathrm{A}$ ", "B", and " $\mathrm{C}$ " mandates. ${ }^{29}$ Working with Near East Relief and others, the League was to ensure that a measure of peace and prosperity was to be brought to the Near East. Though the exchange would not overhaul every facet of the Near East's economy and society, as the mandates system was intended to do, the technologies of power it marshalled were considerable.

\footnotetext{
25 Nehal Bhuta, “Against State-Building” 15 (2008) Constellations 517 at 526 (emphases in original).

26 Cf. Yves Dezalay, "Les courtiers de l'international: héritiers cosmopolites, mercenaires de l'impérialisme et missionnaires de l'universel" 151/152 (2004) Actes de la recherche en sciences sociales 5 at 13.

27 Wilhelm G. Grewe, The Epochs of International Law, tr. and rev. Michael Byers (Berlin: Walter de Gruyter, 2000 [1984]) at 582, 581-5 generally.

${ }^{28}$ Covenant of the League of Nations adopted by the Peace Conference at Plenary Session, April 28, 1919,13 (1919) AJIL Sup. 128 at 137.

${ }^{29}$ On this transition, see, e.g., Georg Schwarzenberger, "The Standard of Civilisation in International Law" 8 (1955) Current Legal Problems 212 at 220, 227; Edward Keene, Beyond the Anarchical Society: Grotius, Colonialism and Order in World Politics (Cambridge: Cambridge University Press, 2002) at 122, ch. 5 generally. For a sustained discussion of the historical evolution of the "standard", see Gerrit W. Gong's classic The Standard of "Civilization" in International Society (Oxford: Clarendon Press, 1984).
} 
A key force behind the implementation of the population exchange was the Office of the League of Nations High Commissioner for Refugees. It shaped general policy on the movements and provided macro-level logistical support throughout their unfolding. This was part of a broader programme of employing the League - despite complaints of ineffectiveness, ${ }^{30}$ a comprehensive "system of world-services" in the words of one, particularly influential technocrat $^{31}$ - as a vehicle for forging a new governmental regime for displaced persons in Europe and beyond. It was largely through the Office of the High Commissioner and its immediate successor, the Nansen International Office for Refugees, that displaced or even "nomadic" peoples, as they had formerly often been known, came to be identified widely as "refugees", objects of state interest and international concern. ${ }^{32}$ It was also on account of this office that some measure of protection was made available to such persons, mainly through the popularization of a new travel document (the "Nansen passport") 33 and the entry into force of the 1933 Refugee Convention, an instrument intended to apply first and foremost to Russian, Armenian, Turkish, and Assyrian refugees. ${ }^{34}$ The First World War had inaugurated a period of increased surveillance of citizens and aliens alike in a number of Western states, with passport controls being introduced or augmented, domestic systems of documentary identification gaining currency, and non-nationals coming to be subjected to intensive regimes of reporting. ${ }^{35}$

\footnotetext{
${ }^{30}$ For a typical example, see Edwin DeWitt Dickinson, The Equality of States in International Law (Cambridge, MA: Harvard University Press, 1920) at 371, 374 (describing League institutions as having only "a little real power", and this mostly of "an advisory or ministerial character").

31 Alfred Zimmern, The League of Nations and the Rule of Law, 1918-1935 (London: Macmillan / St. Martin's, 1936) at 310.

${ }^{32}$ Nevzat Soguk, States and Strangers: Refugees and Displacements of Statecraft (Minneapolis: University of Minnesota Press, 1999) at 127.

33 Otto Hieronymi, "The Nansen Passport: A Tool of Freedom of Movement and of Protection" 22 (2003) Refugee Survey Quarterly 36; John Torpey, The Invention of the Passport: Surveillance, Citizenship and the State (Cambridge: Cambridge University Press, 2000) at 127-9. See also Egidio Reale, "Le problème des passeports" 50 (1934-IV) RCADI 85; François Borella, "Le passeport” 64 (1960) RGDIP 301.

34 Convention relating to the International Status of Refugees, signed on October 28, 1933, 159 LNTS 3663 . It would not be until after the Second World War, when the United Nations High Commissioner for Refugees was established and the 1951 Convention relating to the Status of Refugees entered into force, that something approaching a fully fledged legal regime for protecting refugees would emerge. For contemporaneous contextualization of the 1933 convention, see Louise W. Holborn, "The Legal Status of Political Refugees, 19201938” 32 (1938) AJIL 680 at 689-90. For a more recent analysis, see James C. Hathaway, The Rights of Refugees under International Law (Cambridge: Cambridge University Press, 2005) at 87-91.

35 This was the case even in traditionally immigrant-receiving states like the United States, where new legislation was often so restrictive that it effectively precluded immigration in all cases save those in which the applicant was in possession of a sizable personal fortune or had succeeded in securing a wealthy sponsor. Similar restrictions were introduced in Germany, Italy, and elsewhere. See, e.g., H. A. Citroen, European Emigration Overseas, Past and Future (The Hague: Nijhoff, 1951) at 19; Adam McKeown, "Global Migration, 1846-1940" 15 (2004) Journal of World History 155 at 167, 172 ff. For critical analysis, see John Torpey, "The Great War and the Birth of the
} 
After 1919, though, the coordinated resettlement of whole peoples came to the fore as a fully fledged problem, with the League of Nations setting out to undertake its resolution.

In his capacity as the League's High Commissioner for Refugees, Nansen was at the forefront of these endeavours - so much so that a biographer would later describe him as the "first of his kind", "an international civil servant intruding on what had hitherto been the preserve of diplomats and politicians". ${ }^{36}$ In 1922 Nansen established an "Advisory Committee of Voluntary Organizations" to obtain asylum for or otherwise extend protection to refugees, and secured financial support for his efforts from League member states. ${ }^{37}$ At its inception, this committee counted sixteen organizations as members, among them the International Committee of the Red Cross, the World's Committee of the YMCA, and Near East Relief itself. By 1936, by which time Nansen had died, its membership had expanded to no less than forty such organizations. ${ }^{38}$

In the context of the population exchange, what made Nansen especially effective - and especially useful - was his ability to win the support of each of the state parties without sacrificing his own reputation for humanitarian impartiality. The Kemalists, for instance, might simply have branded him persona non grata due to his closeness to the great powers or his work on behalf of Armenian refugees. İsmet Paşa had, after all, been clear at Lausanne that the Turkish delegation could accord no more than a "personal character" to Nansen's statements, as he was a representative of the League and Turkey had yet to join this organization. ${ }^{39}$ And this would have been very much in keeping with the way in which late Ottoman and early republican politicians tended to engage with League officials. To take but one example, the final report of a League committee charged with overseeing the implementation of the Treaty of Sèvres' provisions respecting the reparation of wrongs committed during the Armenian

Modern Passport System" in Jane Caplan and John Torpey, eds., Documenting Individual Identity: The Development of State Practices in the Modern World (Princeton: Princeton University Press, 2001) 256.

${ }^{36}$ Roland Huntford, Fridtjof Nansen and the Unmixing of Greeks and Turks in 1924 (Oslo: Norwegian Academy of Science and Letters, 1999) at 9.

${ }^{37}$ For details, see "Relief for Refugees from Asia Minor", C. 211 M. 70. 1925. VII., 3 (1922) LNOJ 1140. It should be noted, though, that Nansen also worked closely with other, more established organizations like the ILO. See, e.g., Fridtjof Nansen, "Report by Dr. Fridtjof Nansen of an Enquiry by a Committee of Experts Made in Armenia under the Auspices of the International Labour Office (July 1925)" in Scheme for the Settlement of Armenian Refugees: General Survey and Principal Documents, C. 699. M. 264. 1926. IV. (Geneva: League of Nations, 1927) 65.

${ }^{38}$ For a synthetic account of the relevant League documents, see Claudena M. Skran, Refugees in Inter-war Europe: The Emergence of a Regime (Oxford: Clarendon Press, 1995) at 78-83. For organizational analysis of this committee, see Kévonian, supra note 9, at 343-53.

${ }^{39}$ See supra Chapter III note 62 and accompanying text. 
genocide had condemned the Turkish practice of "adopting" Armenian women and children rendered homeless during the war - a practice not uncommon among elite Ottoman families ${ }^{40}-$ as rapacious and deeply cynical. "You all know the story", the committee's representative had declared when delivering the report to the League General Assembly, of "women withering in their youth in the degrading languor of the harem, children torn from the bosom of their family and cast violently from one race into another, trained to serve those who are bent on the extermination of their own race, and perhaps some day doomed to fight in the ranks of their enemies, each one a new Oedipus trained to kill his parents with his own hands". ${ }^{41}$ In response to this speech, and to the report it introduced, the Ottoman ambassador to Switzerland had written to the General Assembly in equally hyperbolic terms:

"The whole Assembly of the League of Nations, that League of universal brotherhood, moved by Mademoiselle Vacaresco's lyrical talent applauded her expressions of hatred; and though it was far from accurately informed and far from possessing any knowledge of the East and its customs, it responded to this isolated challenge, and, without hearing the accused party or giving him an opportunity to defend himself, without weighing the significance of its action or measuring its consequences, it endorsed the judgment of the poetess, which slandered and cruelly attacked an honest and honourable people, which has been persecuted for centuries and always been vilified as the persecutor. Can such a procedure be called justice - a procedure the disastrous consequences of which affect not merely individuals but a whole peaceful and peace-loving nation?" 42

Nansen was central to the Armenian relief effort, and even Turkish nationalists (like Kemal) who were willing to condemn as criminals those who had played a role in the organization and implementation of the genocide were reluctant to press ahead with their seizure and prosecution once the Allies took to supporting the Greek occupation of western Anatolia. After that point, the question of criminal responsibility came increasingly to be seen not as a sincere attempt to right an extraordinary wrong, but as a weapon in the hands of a West intent on

\footnotetext{
40 See Nazan Maksudyan, "Foster-Daughter or Servant, Charity or Abuse: Beslemes in the Late Ottoman Empire" 21 (2008) Journal of Historical Sociology 488.

${ }^{41}$ Quoted in Keith David Watenpaugh, “The League of Nations' Rescue of Armenian Genocide Survivors and the Making of Modern Humanitarianism, 1920-1927” 115 (2010) American Historical Review 1315 at 1333-4. Such sentiments were pervasive; see, e.g., "Deportation of Women and Children in Turkey and Neighbouring Countries", C. 440 M. 317. 1921. IV., 3 (1922) LNOJ 61 (members of the Greek diaspora in Dresden denouncing "Kemalist barbarism" and urging the League "to intervene immediately to protect the women and children").

42 Quoted in Watenpaugh, supra note 41, at 1334-6 (de-emphasized from original).
} 
further partitioning a resurgent Turkey. ${ }^{43}$ Even so, the Kemalists cooperated with Nansen when negotiating and executing the exchange, drawing on his logistical expertise and professional connections.

That Nansen was able to position himself as something of a mediator was naturally crucial here. In the words of Philip Noel-Baker, the League functionary and international lawyer who advised him at the time, Nansen was used "both as a mediator and the originator of a proposal which, though eminently practical, might bring moral condemnation in its train", arguably the first time in history "that the Powers had asked an international civil servant to pull their chestnuts out of the fire for them". ${ }^{4}$ Not only had he "by his mere public persona all but stifled moralistic criticism of the exchange", both willing and able to absorb "the fire of public opinion" should it ever rain down on the League, but he was "trusted on all sides", 45 a fact which furnished him with the ability to negotiate a shifty diplomatic terrain without eliciting overly aggressive reactions. Nansen was the principal go-between in the diplomatic exchanges between Athens and Ankara leading up to Lausanne, the first to propose a comprehensive population exchange at the conference itself, and the touchstone for nearly all matters relating to its macro-level planning and execution after the conclusion of the Convention of Lausanne. ${ }^{46}$ If the nation-building project of which the population exchange comprised an essential element was indexed on developing a regionally suitable mechanism for manipulating and disciplining ethno-nationalism, then Nansen, the chief representative of the post-1919 "international community" in regards to the exchange, was the main architect of the process through which this was to be achieved.

Of course, Turkey was not the exclusive locus of humanitarian attention in the region. Organizations like Near East Relief operated far and wide, and were in some respects more

43 See Taner Akçam, A Shameful Act: The Armenian Genocide and the Question of Turkish Responsibility, tr. Paul Bessemer (New York: Metropolitan Books, 2006) at 217, 294-302, 371. For a more vitriolic elaboration of the same point, see also Vahakn N. Dadrian, "Genocide as a Problem of National and International Law: The World War I Armenian Case and Its Contemporary Legal Ramifications” 14 (1989) YJIL 221 at 278, 291-326.

${ }^{44}$ Philip Noel-Baker, The League of Nations at Work (London: Nisbet \& Co., 1926) at 11. Closely involved in the League Secretariat and an eventual recipient of the Nobel Peace Prize for his work on behalf of disarmament, Noel-Baker had extensive experience with post-First World War reconstruction and was well-versed in international law. See, respectively, his The Financial Reconstruction of Europe (Geneva: League of Nations, 1922); and "Le statut juridique actuel des dominions britanniques dans le domaine du droit international" 19 (1927-IV) RCADI 248.

45 Noel-Baker, League of Nations at Work, supra note 44, at 15.

46 Michael R. Marrus, The Unwanted: European Refugees from the First World War through the Cold War (Philadelphia: Temple University Press, 2002) at 101. 
active in Greece. It was, after all, Greece which had to settle the lion's share of refugees and which, having to make heavy use of foreign capital in order to do so, acquiesced in an intensive regime of international monitoring during the course of the exchange. Indeed, Near East Relief would eventually move its headquarters from Istanbul to Athens, Greece becoming in Barton's words "a new center of interest and work". 47

Nor, crucially, were elites in Turkey, both before and after the declaration of the Republic, oblivious to the pressures to which they were subjected. As semi-peripheral actors, the Ottomans were both determined and able to shield themselves against (actual or perceived) encroachments on their sovereignty, and established their own relief organizations in response. The Ottoman Red Crescent, the first organization of its kind in the non-European world, had, for instance, been bolstered significantly during and immediately following the First World War, and would assume responsibility for providing food, shelter, and medical attention to more than a hundred thousand refugees between 1919 and 1923. ${ }^{48}$ The Porte generally viewed missionary activity as one of the many instruments with which imperialist powers sought to undermine the Empire's social and territorial integrity, locating, and where possible actively supporting, minorities capable of facilitating greater cultural and commercial penetration of Anatolia. It sought to restrict their reach, regardless of the specific denomination with which they might be affiliated and even where the missionaries with whom they dealt made a point of adopting conciliatory postures so as to stand a better chance of operating unimpeded. ${ }^{49}$ In some cases this was achieved through police action. In other cases, such as those in which even the absence of a formal license to maintain a mission proved insufficient to legitimate direct action, ${ }^{50}$

\footnotetext{
${ }^{47}$ Barton, Story, supra note 4, at 161.

${ }^{48}$ Nadir Özbek, Osmanl İmparatorluğu’nda Sosyal Devlet: Siyaset, İktidar ve Meşruiyet 1876-1914 (İstanbul: İletişim, 2002) at 323 (arguing that the Red Crescent was responsible for "the most important contribution to the 'nationalization' and 'militarization' of the [Ottoman] public sphere" (translation mine)). For a brief but useful sweep of the growth of Ottoman philanthropic organizations, see Fatma Müge Göçek, Rise of the Bourgeoisie, Demise of Empire: Ottoman Westernization and Social Change (Oxford: Oxford University Press, 1996) at 46-7.

49 Selim Deringil, The Well-Protected Domains: Ideology and the Legitimation of Power in the Ottoman Empire 1876-1909 (London: Tauris, 1998) at 112-34. Howard S. Bliss, the Syrian Protestant College's president, would thus encourage his colleagues to drop incendiary rhetoric so as better to be able to spread the good news: "One result of this effort to approach Islam in the spirit of sympathy and appreciation will be to prune our missionary vocabulary of many disfiguring and irritating words. We shall not talk about 'modern crusades'; we shall not speak of Islam as a 'challenge to faith.' Except indeed as applied to our struggle against weaknesses and temptations common to humanity, we shall drop the whole vocabulary of war." Quoted in Hans-Lukas Kieser, Nearest East: American Millenialism and Mission to the Middle East (Philadelphia: Temple University Press, 2010) at 72.

50 This was also common elsewhere; the absence of licenses did not, for example, keep British missionaries from operating under the auspices of the East India Company. Jörg Fisch, "A Pamphlet War on Christian Missions in India 1807-1809” 19 (2005) Journal of Asian History 22 at 40.
} 
recourse was had to less overtly coercive means like establishing schools to reconvert those who had deviated from the Islamic mainstream and were hesitant to undertake military service on behalf of the sultan-caliph. ${ }^{51}$

The Kemalists, for their turn, were suspicious of humanitarian organizations, particularly the influence they wielded over matters of education. And this influence was anything but negligible: a 1929 study, for instance, claimed that all American schools in Turkey but one had been established by mission boards. ${ }^{52}$ The Lausanne peace settlement did not introduce any new significant legal constraints on foreign-funded schools in Turkey, and actually provided for public education in native tongues for members of non-Muslim minorities. ${ }^{53}$ But the Kemalists, determined to counter the influence of such schools, promulgated a series of laws to maximize the state's supervisory powers over them. While the Kemalists typically did not go so far as to do what their Ottoman forebears had done and simply expel non-nationals whom they regarded with distrust on what Westerners frequently and often justifiably viewed as arbitrary grounds, ${ }^{54}$ these laws - enacted by Ankara from 1924 to 1939 - brought schools run by or for foreigners under the authority of a newly established ministry of education, doing away with the use of religious symbols and introducing severe restrictions on the conditions under which religious classes could be taught. ${ }^{55}$ The cumulative result of these and related measures was a significant drop in the number of such establishments in Turkey, with forty French and four Italian schools closing in November 1922 alone, some two years before the first such laws took effect. ${ }^{56}$

This paralleled the Kemalists' efforts to envelop the population exchange in a series of citizenship and immigration laws that were intended to ensure that Turkification efforts would

\footnotetext{
${ }^{51}$ Selçuk Akşin Somel, The Modernization of Public Education in the Ottoman Empire, 1839-1908: Islamization, Autocracy and Discipline (Leiden: Brill, 2001) at 158, 206. And for this struggle over educational institutions, a struggle in which Ottoman schools were often used as a defense against foreign intervention, see Benjamin C. Fortna, Imperial Classroom: Islam, the State, and Education in the Late Ottoman Empire (Oxford: Oxford University Press, 2002), ch. 2. For broader contextualiztion in late Ottoman social engineering programmes, see Selim Deringil, "Osmanlı'dan Türk'e: Türkiye'de Kimlik ve Sosyal Mühendislik" in Selim Deringil, Simgeden Millete: II. Abdülhamid'den Mustafa Kemal'e Devlet ve Millet (İstanbul: İletişim, 2007) 93 at 99-100 ff.

52 Frank A. Ross, C. Luther Fry, and Elbridge Sibley, The Near East and American Philantbropy: A Survey Conducted under the Guidance of the General Committee of the Near East Survey (New York: Columbia University Press, 1929) at 156.

53 Treaty of Peace, signed at Lausanne, July 24, 1923, 28 LNTS 11, Art. 41, at 35.

${ }^{54}$ For a comparative analysis, see Guy S. Goodwin-Gill, International Law and the Movement of Persons between States (Oxford: Clarendon Press, 1978) at 207, ch. 11 generally.

${ }^{55}$ For a general discussion, see Ayten Sezer, Atatürk Döneminde Yabancı Okullar (1923-1938) (Ankara: Türk Tarih Kurumu Basimevi, 1999) at 15-35.

56 Ibid., at 22.
} 
bear fruit. The 1926 Law on Settlement (İskân Kanunu) settled ethnic Turkish and "loyal" Muslim immigrants in strategically sensitive areas, particularly in east and southeast Anatolian provinces given to rebellion. ${ }^{57}$ By 1926 parliamentarians had already passed a number of laws and issued a variety of decrees and regulations to resettle immigrants in the Republic's hinterland on the basis of newly conducted censuses. Implemented partly by the interior ministry and partly under the auspices of an ill-equipped and under-funded ministry for "exchange, reconstruction, and settlement" (mübadele, imar, ve iskên), ${ }^{58}$ such legislation eased the naturalization of Turks and Muslims from former Ottoman provinces. ${ }^{59}$ The system enshrined in this legislation would eventually lead to an even more strident settlement law in 1934. Dividing the country's territory into three "zones of settlement", this law was designed to enhance ethnic homogeneity and consolidate national security. ${ }^{60}$ Despite (or, perhaps, because of) large-scale local resistance, ${ }^{61}$ the law received ample support from the Kemalist establishment, with one member of the national assembly declaring that it would be "distinguished as one of the foremost laws of the revolution", seeing as how it would "soak all, who live in this land, with the honor and the appreciation of being Turkish", ${ }^{62}$

The Kemalists' reluctance to give free rein to foreign-funded schools and similar institutions did not, of course, go unnoticed. In 1924, when preparing a report commissioned by Kemal's government concerning the measures that were to be taken for a "modern"

${ }^{57}$ Soner Çağaptay, Islam, Secularism, and Nationalism in Modern Turkey: Who is a Turk? (New York: Routledge, 2006) at 84-8. It is not unimportant here that a large-scale revolt, fed by Kurdish nationalism and Islamic revivalism, had broken out in southeastern Anatolia province only a year earlier. Bolstering support for the revolt was the fact that the Ankara government had abolished the caliphate, introduced controversial legal reforms regarding public dress, and reneged on its promise to accord greater autonomy to Kurds. See in particular Robert Olson, The Emergence of Kurdish Nationalism and the Sheikh Said Rebellion, 1880-1925 (Austin: University of Texas Press, 1989), ch. 5; and also Martin van Bruinessen, Agha, Shaikh and State: The Social and Political Structures of Kurdistan (London: Zed Books, 1992), ch. 5.

58 For details on the establishment and early work of this ministry, see especially Kemal Ar1, Büyük Mübadele: Türkiye'ye Zorunlu Göc (1923-1925) (İstanbul: Tarih Vakfi Yurt Yayınlar1, 1995) at 22-49. For a regional case study, see Nedim İpek, Mübadele ve Samsun (Ankara: Türk Tarih Kurumu Basımevi, 2000), esp. at 35-43.

59 Soner Çağaptay, "Population Resettlement and Immigration Policies of Interwar Turkey: A Study of Turkish Nationalism" 25 (2001) Turkish Studies Association Bulletin 1 at 8-9.

${ }^{60}$ Çağaptay, Islam, Secularism, and Nationalism, supra note 57, at 88-92; Kemal Kirişci, "Migration and Turkey: The Dynamics of State, Society and Politics" in Reșat Kasaba, ed., The Cambridge History of Turkey, Vol. IV (Cambridge: Cambridge University Press, 2006) 175 at 180-1; Erol Ülker, "Assimilation, Security and Geographical Nationalization in Interwar Turkey: The Settlement Law of 1934” 7 (2008) European Journal of Turkish Studies at paras 18-23, available online at: http://www.ejts.org/document2123. html (last accessed 6 April 2011).

${ }^{61}$ In 1937-8, a large-scale revolt erupted in Dersim, a predominantly Kurdish province which had been renamed Tunceli and subjected to significant population movements under the terms of the 1934 law and a variety of other pieces of legislation. It was put down by Turkish authorities - with tens of thousands of lives lost in the process. See especially İsmail Beşikçi, Tunceli Kanunu (1935) ve Dersim Jenosidi (İstanbul: Belge Yayınları, 1990).

${ }^{62}$ Quoted in Çağaptay, Islam, Secularism, and Nationalism, supra note 57, at 88. 
educational system to be established in Turkey, John Dewey would feel the need to offer some cautionary advice to American humanitarian organizations operating in the country in a series of essays in The New Republic. Given the ends to which foreign schools, some exclusive to children of non-Muslim families and with an explicitly religious mandate, ${ }^{63}$ had been put in the past, it was "not surprising", Dewey wrote, "that the Turks are antecedently disposed to approach the question of all foreign schools with suspicion as to their bias". ${ }^{64}$ They had "the very best of reasons to be suspicious of the admixture of foreign politics and foreign religions" in matters of education, and, in pressing for laicist reforms in all such schools, were often simply following the West's lead. ${ }^{65}$ The key to deflating these suspicions, and thereby concentrating all available resources on elevating Turkey's "civilizational" standards, lay in a shift of tactics:

"If the religious purpose is to continue to dominate American schools or even to color them in any marked way ... [,] American institutions will continue to deal mainly with non-Turkish elements in the population, and hence remain an essentially alien and suspected factor in the Turkish body politic. On the other hand, these institutions can play an immensely useful rôle in the modernization of Turkey on condition that they devote themselves primarily to education of Turkish young men and women - a condition which definitely means the complete subordination of Christian religious aims, and the surrender of the schools, in spirit as well as in outward form, to secular social and scientific methods.... Any failure to meet [this dilemma] or effort to straddle it will result in continued friction between American and Turkish interests, and service which American ideas and ideals are capable of rendering at a critical juncture to the experiment of transforming Turkey. And it hardly need be said that the success or failure of this experiment, in view of the consequences both in the Near East and in the Moslem world, is of immense import to the future peace of the world.",66

What Dewey characterized as an "experiment", a matter of social engineering driven by a sober assessment of Turkey's “two greatest immediate needs, schools and a competent and honest

63 Robert College, often styled as the first American high school outside the United States itself, rooted its curriculum in scripture from the very outset. Its student body was for many years restricted to children of nonMuslim expatriates and local non-Muslim elites, and even some of its faculty regarded it as an instrument of Christian proselytizing. See Marcia Stevens and Malcolm Stevens, Against the Devil's Current: The Life and Times of Cyrus Hamlin (Lanham, MD: University Press of America, 1988) at 271, 273-4; and, for a first-hand account from its founder, Cyrus Hamlin, Among the Turks (New York: American Tract Society, 1877), ch. 19.

${ }^{64}$ John Dewey, "Foreign Schools in Turkey" 41 (1924) The New Republic 40 at 40.

${ }_{65}$ " $[\mathrm{n}] \mathrm{n}$ reply to a protest regarding the closing of Catholic schools which refused to abide by the rules for strictly lay education, the French were asking for privileges for their schools in Turkey which had long been forbidden by law in France itself." John Dewey, "Secularizing a Theocracy" 40 (1924) The New Republic 69 at 71.

${ }^{66}$ Dewey, "Foreign Schools", supra note 64, at 41. 
civil administration", ${ }^{67}$ was also a project, one that sought to fasten the nationalist enthusiasm of a young republic to a broader transformative agenda. More to the point, it was also a mission, an essential part of the project of redemption that Near East Relief and related organizations undertook on the back of the population exchange. That Dewey warned against careless manipulation of foreign-funded schools and underscored their political significance with as much passion as he did speaks to the pressures to which the Kemalists' were subjected.

The nation-building enterprise the population exchange facilitated was thus not simply an exercise in externally induced regime change; it was also an opportunity for advocates of Turkish nationalism to strengthen their state with a view to countering intervention. Near East Relief and similar organizations were to be allowed access to the country and its people. But much of the general suspicion regarding humanitarian organizations which late Ottoman policymakers had harboured was inherited by the nationalists of the early Turkish Republic.

This point is well worth emphasizing, as it underscores, in still another dimension, the distinctive character both of the Near East and of the mechanism that was employed to complete its transition to national statehood. The late Ottoman reformers and Turkish nationalists who looked askance at Euro-American humanitarianism were not inclined to see themselves as peripheral figures, resigned to a fate that had befallen them. On the contrary, they generally understood themselves to be active participants in a complex sequence of disputes that offered opportunities as well as challenges. Acting with an eye to the recent past, the Kemalists in particular believed that philanthropic humanitarianism, once allowed to gain a foothold, could acquire recruits and sympathizers without much difficulty. Quite apart from the fact that many of the cultural and educational contributions the nineteenth-century missionary groups had made to everyday life in Asia Minor were driven by a militant anticipation of redemption, often fed by "success" in other parts of the world, ${ }^{68}$ some of these groups had played a role in facilitating the Empire's fragmentation, in the most incendiary cases by funding or offering logistical assistance to insurrectionary movements in provinces with significant non-

${ }^{67}$ John Dewey, "The Problem of Turkey" 41 (1924) The New Republic 162 at 163.

68 The first American missions to the Middle East, established in the nineteenth century, were, for example, undertaken partly with the intention of replicating the full-scale conversion of Native Americans on the Great Plains. See Ussama Makdisi's extraordinary Artillery of Heaven: American Missionaries and the Failed Conversion of the Middle East (Ithaca: Cornell University Press, 2008). 
Muslim minorities. ${ }^{69}$ Assistance need not always bring control in its train, and is, of course, conceptually distinguishable from it. ${ }^{70}$ But in this case the two were often regarded as substantively indistinguishable. For the Turkish nationalism that was forged through war, displacement, and imperial disintegration, the humanitarian drive to partition and save - a drive with which the population exchange was closely associated and for which it made considerable room - was largely anathema. One could, perhaps, find no more apt a slogan for this stance than Proudhon's famous dictum, revived by Schmitt at the time of the exchange and broadly representative of the sensibilities of those at the helm of the Turkish Republic, a state whose very survival was regarded as intimately bound up with the expulsion of many non-Muslim communities: "whoever invokes humanity wants to cheat". ${ }^{71}$

\section{"National Sovereignty is Not Affected by the Convention in Question"}

The Permanent Court of International Law's advisory opinion in Exchange of Greek and Turkish Populations is analyzed only infrequently, and then somewhat obliquely. Verzijl devotes barely four pages to the opinion in his monumental two-volume work on World Court jurisprudence. And when he does venture an assessment of the Court's reasoning, he offers little more than a flat statement to the effect that "[t]he legal situation under the relevant instruments was ... so clear and the reasoning of the Opinion so convincing that it cannot create a surprise that the Court was unanimous". ${ }^{72}$ On his account, the opinion is best read as the product of a fairly straightforward attempt on the part of a newly established international judiciary to cut to the

${ }^{69}$ Uygur Kocabaşoğlu, Anadolu'daki Amerika: Kendi Belgeleriyle 19. Yü̈ynlda Osmanl Imparatorluğu'ndaki Amerikan Misyoner Okullar (Ankara: İmge, 2000); Eleanor Tejirian and Reeva Simon, eds., Altruism and Imperialism: Western Cultural and Religious Missions in the Middle East (New York: Middle East Institute, Columbia University, 2002); HansLukas Kieser, Iskalanmış Barıs: Doğu Vilayetlerinde Misyonerlik, Etnik Kimlik ve Devlet 1839-1938, tr. Atilla Dirim (İstanbul: İletişim, 2005).

70 Though it should be noted that some interwar jurists did not always draw the sharpest of distinctions between them. See, e.g., F. M. van Asbeck, "The Relationship between International and Colonial Law" [1931] in F. M. van Asbeck, International Society in Search of a Transnational Legal Order: Selected Writings and Bibliography, eds. H. F. van Panhuys and M. van Leeuwen Boomkamp (Leyden: Sijthoff, 1976) 48 at 63-4 (arguing that an extra-European state's attempt to augment its "domestic political power" with a view to preparing "for participation in the intercourse of the community of nations" always involves a transition from its being "governed" to "aided" and finally to "allied" - states of affairs which are distinguishable but which lie on a common spectrum).

${ }^{71}$ Carl Schmitt, The Concept of the Political, tr. George Schwab (Chicago: University of Chicago Press, 1996 [1932]) at 54.

${ }^{72}$ J. H. W. Verzijl, The Jurisprudence of the World Court: A Case by Case Commentary, Vol. I (Leyden: Sijthoff, 1965) at 144, 140-4 for the entire discussion. 
quick in a matter of extreme urgency. As the terms of the Convention of Lausanne were clear, the dispute regarding the status of "les établis" - a term reserved under Article 2 of the Convention of Lausanne for a specific category of Greeks exempted from the compulsory exchange due to their status as residents of Istanbul before a particular date - was one which strict interpretation of the instrument governing the exchange procedure resolved rapidly and decisively. ${ }^{73}$ In a roughly similar tone, a 1932 survey of the Permanent Court's jurisprudence notes that the opinion's significance lay principally in the fact that it testified to the flexibility and substantive merit of the advisory procedure, and secondarily in the fact that one of the parties to the dispute which gave rise to it was not a member of the League. ${ }^{74}$

What has attracted little attention in the few available analyses that exist of the Exchange opinion is the way in which the Court's opinion jostled with many of the same questions of identity and internationalism that undergirded the humanitarian effort to partition and save the Near East. The Court drew a sharp distinction between domestic and international law in rejecting a Turkish argument to the effect that a certain class of Greeks resident in Istanbul should be subjected to the compulsory exchange. This led it to relate nationalism to international order in a way that bore a structural similarity to the approach adopted by many of the humanitarian organizations involved in the exchange. Specifically, the Court's decision to interpret the category of "les établis" without recourse to Turkish municipal law paralleled the attempt made by members of Near East Relief and similar groups to combat ethno-nationalism.

At root, the case turned on the interpretation of Article 2 of the Convention of Lausanne. As will be remembered, this provision instituted a compulsory exchange between "Turkish nationals of the Greek Orthodox religion" and "Greek nationals of the Moslem religion", carving out exceptions to this general rule in the case of Muslims inhabiting western Thrace and Greeks "established" in Istanbul. ${ }^{75}$ Both of these general categories, as well as their exceptions, were, of course, quite murky: not only was it often unclear who was to be placed in

\footnotetext{
${ }^{73}$ Ibid., at 143.

${ }^{74}$ Alexander P. Fachiri, The Permanent Court of International Justice: Its Constitution, Procedure and Work, $2^{\text {nd }}$ Ed. (London: Oxford University Press, 1932) at 209. For other examples, see, e.g., J. W. Wheeler-Bennett, Information on the World Court, 1918-1928 (London: George Allen \& Unwin Ltd., 1929) at 124-6; Manley O. Hudson, The World Court, 1921 1938: A Handbook of the Permanent Court of International Justice, $5^{\text {th }}$ Ed. (Boston: World Peace Foundation, 1938) at 186-9.

75 Convention concerning the Exchange of Greek and Turkish Populations, and Protocol, signed at Lausanne, January 30, 1923, 32 LNTS 75 at 77. Again, it will be recalled that Greeks resident on two Aegean islands Imbros/Gokçeada and Tenedos/Bozcaada - that had been assigned to Turkey were also exempted: Lausanne Peace Treaty, supra note 53, Art. 14, at 17.
} 
one class and who in another, but the parameters of the special zones the convention made possible were not particularly precise. It was with issues growing out of this lack of precision that the Permanent Court was forced to grapple in Exchange of Greek and Turkish Populations. Article 2 stipulated that "[a]1l Greeks who were already established before October $30^{\text {th }}, 1918$, within the areas under the Prefecture of the City of Constantinople, as defined by the law of 1912, shall be considered as Greek inhabitants of Constantinople" ${ }^{76}$ But among those "Turkish nationals of the Greek Orthodox religion" who were deemed to fall under this category, at least potentially or prima facie, were a sizable number whom Turkish authorities deemed ineligible to benefit from the exemption. ${ }^{77}$

For most members of the Turkish political elite, that a considerable number of Greeks had settled in Istanbul during the 1910s presented a serious strategic challenge. Acutely conscious of the fact that their state was situated on the semi-periphery of the international system, and convinced that this made it particularly vulnerable to destabilization in the hands of what were often referred to as "internal and external enemies", ${ }^{78}$ most Turkish nationalists sought to restrict this community's power. In their eyes, the larger and more resourceful the Greek population of Istanbul was, the greater the threat would be to Turkey's security and sovereignty, if not sooner than certainly later. ${ }^{79}$ While the Turkish delegation at Lausanne had been forced to concede that Greeks properly "established" in Istanbul would be exempted from the exchange, they were determined to keep the numbers this exemption allowed to an absolute minimum. At its crassest and most direct, this led to the seizure of 4500 Greeks, who were threatened with immediate deportation. ${ }^{80}$ More subtle and less direct, but no less insistent, was

\footnotetext{
${ }^{76}$ Convention of Lausanne, supra note 75 , at 77.

77 Unsurprisingly, though, the precise size was, as elsewhere, subject to debate. Like so many others, Isaiah Bowman, geographer and territorial advisor to the American delegation at the Paris Peace Conference, complained regularly of the proliferation of "statistical and cartographical tricks" after the First World War. See "Constantinople and the Balkans" in Edward M. House and Charles Seymour, eds., What Really Happened at Paris: The Story of the Peace Conference, 1918-1919 (New York: Charles Scribner's Sons, 1921) 140 at 142; and, for contextual analysis, Neil Smith, American Empire: Roosevelt's Geographer and the Prelude to Globalization (Berkeley: University of California Press, 2003) at 147 ff. For Bowman's take on Turkey's partition, see Isaiah Bowman, “A Note on the Political Map of Turkey" 1 (1922-3) Foreign Affairs 159.

${ }^{78}$ For incisive contextual analysis, see Taha Parla and Andrew Davison, Corporatist Ideology in Kemalist Turkey: Progress or Order? (Syracuse: Syracuse University Press, 2004) at 251.

${ }^{79}$ A typical example is that of Halide Edip Adivar, a nationalist and feminist pioneer who would tell Kemal that Christian minorities, if allowed to remain in Turkey, would "continually provide a pretext for foreign interference". Quoted in Harry J. Psomiades, The Eastern Question: The Last Phase - A Study in Greek-Turkish Diplomacy (Thessaloniki: Institute for Balkan Studies, 1968) at 71.

${ }^{80}$ Exchange of Greek and Turkish Populations (Lausanne Convention VI, January 30 th, 1923, Article 2), Advisory Opinion, PCIJ Rep. Series B. No. 10 (1925) at 12-3. For details, see Stephen P. Ladas, The Exchange of Minorities: Bulgaria,
} 
the legal position that Turkey adopted during discussions with the mixed commission and before the Permanent Court in the Exchange case. For the Turks, Article 2 of the Convention of Lausanne was best understood against the background of two Turkish laws concerning domicile. These two pieces of legislation, promulgated in 1902 and 1914 respectively, set out the conditions for individuals to be "established" legally in Turkey, and did so in terms more restrictive than those permitted on most readings of the Convention of Lausanne. ${ }^{81}$ If the category of "les établis", as it appeared in the Convention of Lausanne, were defined by reference to these Turkish laws, Article 2 would be applicable to a much smaller class of individuals than would be the case if "les établis" were defined independently of these laws. According to Turkish authorities, any other interpretation of Article 2 would violate Turkey's sovereignty and independence. Indeed, "[i]t is obvious”, argued Tevfik Rüştü, the Turkish government's representative in the case, "that to attempt for any reason to suspend the application of this law to any portion of the citizens of a country is tantamount to granting such citizens a privilege and also to an infringement of the rights of other minorities and of the majority". Further, he stated, "[u]ntil it is proved that under the terms of the Convention this law must be modified or suspended, it cannot be touched without infringing the sovereign rights of Turkey and the Turkish nation". ${ }^{82}$

Greek authorities threw their weight behind the opposing interpretation of Article 2. In their eyes, this provision needed to be taken on its own terms rather than read as referring implicitly or explicitly - to any external source of normative obligation, least of all the Turkish legislation in question. According to the Greeks, Article 2 meant one thing and one thing alone - namely, and as framed by Nicolas Politis, Greece's usual agent before the Permanent Court and the lead advocate in this case, that "the word "established" meant nothing more nor less than the "inhabitants of Constantinople who had taken up their residence there before October $30^{\text {th }}, 1918$, with the intention of habitually residing there". ${ }^{83}$ The Greeks were particularly concerned about the status of the Ecumenical Patriarchate, the institutional and spiritual fountainhead of eastern Orthodoxy. Because Constantinople had housed the patriarchate since the fourth century AD, and because it was revered by Orthodox believers, Politis and other

Greece and Turkey (New York: Macmillan, 1932) at 404-5; Onur Yıldırım, Diplomacy and Displacement: Reconsidering the Turco-Greek. Exchange of Populations, 1922-1934 (New York: Routledge, 2006) at 114-6.

${ }^{81}$ For details, see Exchange of Greek and Turkish Populations, supra note 80, at 11, 15-6, 21-2.

82 Ibid., at 15-6.

${ }^{83}$ Ibid., at 15. 
Greek representatives were keen to shield it from the exchange procedure: relocating it was simply unthinkable. ${ }^{84}$ Suspicious of the patriarchate, the Turks would insist that the question of its legal status was wholly internal to Turkish law: since the mixed commission had ruled that it was not competent to decide whether the patriarch, considered in his institutional (rather than merely personal) capacity, ought to be subject to the exchange, and since neither the Convention of Lausanne nor any other instrument concluded at Lausanne made specific mention of his office, Turkey was fully within its rights to reject Greece's attempt to "intervene in the constitution and administration" of a "Turkish domestic institution". 85 The Greeks countered by arguing that İsmet Paşa had sought to have the patriarchate included in the exchange procedure at Lausanne, that this proposal had been rejected roundly after causing considerable controversy, and that it was therefore only on the basis of a shared understanding that the patriarchate was to be excluded from the exchange that the convention had been concluded. ${ }^{86}$ Politis brought to this aspect of the dispute the same attention he devoted to the broader question of defining "les établis" - and, interestingly, much the same commitment to constraining state power that he had displayed when explaining that arbitrary expulsions of nonnationals were abusive and ran counter to prevailing international legal norms in his course at the Hague Academy of International Law that same year. ${ }^{87}$ Bolstering this position was the fact that many Greek international lawyers were dedicated to what would now be termed the monist

\footnotetext{
${ }^{84}$ The Greeks would bring the matter to the attention of the League Council: see "Question of the Expulsion of the Ecumenical Patriarch - Expulsion of the Ecumenical Patriarch from Constantinople. Appeal by the Greek Government under Paragraph 2 of Article 11 of the Covenant", C. 57. M. 30. 1925. VII., 6 (1925) LNOJ 579. Interestingly, comparisons can be drawn between the Greek position on the patriarchate and the controversies that surrounded the legal status of Mount Athos. As the site of many of Orthodox Christianity's most significant monasteries, Mount Athos - a peninsular mountain in Greek Macedonia - was recognized as independent under the Treaty of Berlin but annexed to Greece under the Treaty of Lausanne. Though the Greek constitution provided autonomy for Mount Athos within the Greek state's parameters, the precise nature and scope of this autonomy remained contested for some time. In 1927, for instance, the Salonika Court of Appeal ruled that monastic authorities in Mount Athos were competent to preside over proprietary and ecclesiastical disputes but lacked jurisdiction to adjudicate criminal cases. See Monasteries of Mount Athos Case [1929] ADPILC 315.

85 "Question of the Expulsion of the Ecumenical Patriarch - Letter from the Turkish Government to the Secretary-General of the League, Submitted to the Council on March 14 $4^{\text {th }}, 1925^{\prime \prime}$, C. 160. 1925. VII., 6 (1925) LNOJ 579 at 580 .

86 "Question of the Expulsion of the Ecumenical Patriarch - Letter and Memorandum from the Greek Government to the Secretary-General of the League", C. 211. M. 70. 1925. VII., 6 (1925) LNOJ 637 at 638. See also Exchange of Greek and Turkish Populations, supra note 80, at 14, 16.

${ }^{87}$ Nicolas Politis, "Le problème des limitations de la souveraineté et la théorie de l'abus des droits dans les rapports internationaux" 6 (1925-I) RCADI 1 at 107-8. Also significant is the fact that he would make a point of singling out the generosity of American charities during the course of the population exchange in his classic La morale internationale. See Nicolas Politis, La morale internationale (New York: Brentano's, 1944) at 124.
} 
thesis that international law is part of domestic law even in the absence of specific legislation to that effect. $^{88}$

As is often the case, the entanglements to which this dispute gave rise played out in a number of fora before they were finally brought before the Permanent Court. The dispute appears to have got its start after the Convention of Lausanne entered into force and when the mixed commission it constituted started its liquidation and compensation work. Unable to agree on the proper interpretation of Article 2, the Turkish and Greek members of the commission submitted independent memoranda on the question. The dispute was not resolved when the commission and the two sets of members convened on 4 September 1924 for discussions. After several additional meetings, and even an ineffective resolution by the commission's legal section, ${ }^{89}$ the Greeks exercised their right under Article 11 of the League of Nations Covenant ${ }^{90}$ to refer the question of "les établis" to the League Council in October 1924. Finally, the Council of the League of Nations requested officially that the Court offer its opinion on how the matter should be settled.

The Court was presented with two questions. First, there was the question of "[w]hat meaning and scope should be attributed to the word 'established' in Article 2 of the Convention of Lausanne of January $30^{\text {th }}$, 1923, regarding the exchange of Greek and Turkish populations". Second, the Court was asked to respond to the question of "what conditions must the persons who are described in Article 2 of the Convention of Lausanne under the name of 'Greek inhabitants of Constantinople' fulfil in order that they may be considered as 'established' under the terms of the Convention and exempt from compulsory exchange?"91

In setting out the reasoning underlying its response to the first of these two questions, the Court progressed in several stages. It began by stating that the question of the Ecumenical Patriarchate's status was not relevant to the case at hand, as the League Council had not

\footnotetext{
${ }^{88}$ For a strong example from another Greek luminary, see C. G. Ténékidès, "Le droit international public envisagé comme source du droit interne hellénique" 9 (1928) RDILC 338.

89 Exchange of Greek and Turkish Populations, supra note 80, at 12. The commission essentially agreed with the Greek position, deciding that all Greeks inhabiting Istanbul before 30 October 1918 were to be exempted from the exchange unless it could be proven that they had had no intention of remaining there. (The commission set out a handful of criteria for determining whether this intention had or had not been present.) Tevfik Rüştü was disgusted by this resolution, stating that "it would not be accepted by the Turkish delegation even though the majority should so decide" and threatening that the Turks "would not even take part in the work of the Mixed Commission" if it were allowed to stand. See Ladas, supra note 80, at 403.

${ }^{90}$ League Covenant, supra note 28, at 132.

${ }^{91}$ Exchange of Greek and Turkish Populations, supra note 80, at 7.
} 
requested that the Court offer its opinion on it. ${ }^{92}$ It then noted that the meaning and scope of the term "established" was not to be determined in abstracto, but only within the context of its usage in Article 2. As such, the dispute at hand was one that turned on the most appropriate interpretation of a treaty, involving a proper question of international - and not domestic - law. Put differently, the difference of interpretation in regards to Article 2 concerned not "a question of domestic concern between the administration and the inhabitants" of a particular territory, but a "difference affect[ing] two States which have concluded a Convention with a view to exchanging certain portions of their populations". ${ }^{93}$

This had far-reaching implications for the Court's assessment of Article 2. Considered not from a domestic but from a properly international legal standpoint, the significance of Article 2's reference to persons "established" in Istanbul was in its view quite clear. The French établissement (the French version of the convention's text being authoritative) denoted both residence and stability - that is, "an intention to continue the residence in a particular place for an extended period". ${ }^{94}$ The Court conceded that this could be understood to beg the question as to whether the conception of "establishment" which underlay Article 2 was ultimately identical to the doctrine of domicile in conflict of laws. As already mentioned, an argument along these lines had been advanced by Turkey; given that an individual's domicile is incapable of being ascertained without recourse to matters of domestic jurisdiction, it would naturally have lent support to Turkey's claim that Article 2 was fundamentally unintelligible when read independently of Turkish national legislation. The Court rejected this argument, however, holding that neither the text nor the travaux of the convention could be said to warrant such an interpretation of "establishment". The text simply did not evidence any express or tacit reference to domicile, and there was no "indication that the authors of the Convention ... had in mind national legislation at all". ${ }^{95}$ What is more, reading Article 2 on the basis of national legislation, Turkish or Greek, would have engendered a number of logistical delays and difficulties: the multijurisdictional complexities it would have produced would have led "to the division of the population being carried out in a different manner in Turkey and in Greece", which, in turn, would not have been "in accordance with the spirit of the Convention, the

\footnotetext{
92 Ibid., at 17.

93 Ibid., at 17-8.

${ }^{94}$ Ibid., at 18.

95 Ibid., at 20.
} 
intention of which is undoubtedly to ensure, by means of the application of identical and reciprocal measures in the territory of the two States, that the same treatment is accorded to the Greek and Turkish populations". ${ }^{96}$

Thus, the Court concluded, if Article 2 created an exception to the general category of those "Turkish nationals of the Greek Orthodox religion" who were to be forcibly exchanged, the "Greek inhabitants of Constantinople" to which Article 2 referred meant simply those persons who "reside within the boundaries of the Prefecture of the City of Constantinople as defined by the law of 1912; have arrived there, no matter whence they came, at some date previous to October $30^{\text {th }}, 1918$; and have had, prior to that date, the intention of residing there for an extended period". ${ }^{97}$ This was its "natural meaning". ${ }^{8}$ Anything more would make for a cumbersome and unjustified interpretation of the convention.

The Court supported its holding in respect to the question of treaty interpretation with a number of interesting subsidiary arguments - each one designed to counter a specific claim that had been put forward by Turkey. For one thing, Turkey had argued that another provision of the Convention of Lausanne, Article 18, made direct reference to domestic legislation, stating that " $[\mathrm{t}]$ he High Contracting Parties undertake to introduce in their respective laws such modifications as may be necessary with a view to ensuring the execution of the present Convention". ${ }^{99}$ Predictably, Turkey had pointed to this provision in an attempt to show that Article 2 was organically intertwined with Turkish domestic law. This was dismissed by the Court on the grounds that a general background obligation to modify one's national laws with a view to ensuring compliance with one's international treaty obligations in no way meant that a reference to one or another set of such laws needed to be read into Article 2's language about "establishment". "[I]t does not in the least follow", the Court explained, "because the contracting Parties are obliged to bring their legislation into harmony with the Convention, that

\footnotetext{
${ }^{96}$ Ibid., and also at 22.

97 Ibid., at 26.

98 Ibid., at 20. "Natural meaning" was an integral, if highly amorphous, element in the Court's analytical lexicon. For a breakdown, including details on cognates such as "reasonable meaning", "rational interpretation", "proper construction", "correct construction", see J. P. Fockema Andrex, An Important Chapter from the History of Legal Interpretation: The Jurisdiction of the First Permanent Court of International Justice (1922-1940) (Leyden: Sijthoff, 1948) at 578. For related usage in arbitral bodies, see also Robert R. Wilson, "Some Aspects of Treaty Interpretation" 33 (1939) AJIL 541 at 542.

${ }^{99}$ Convention of Lausanne, supra note 75, at 85. See also Exchange of Greek and Turkish Populations, supra note 80, at 20.
} 
that instrument must be construed as implicitly referring to national legislation in so far as that is not contrary to the Convention". ${ }^{100}$

In similar fashion, the Court rejected a Turkish argument that since the term "established" was not itself a legal one, its precise legal significance - its meaning under the convention and its implications for the work of the mixed commission - could only be determined by reference to specific pieces of national legislation. The Court agreed that "established" was not, strictly speaking, a legal term, or at least was not a term that could be said to have a conventional and well-known legal definition. But it nevertheless reasoned that its appearance in a treaty, an unquestionably legal document, was sufficient to accord it a distinct legal significance, and that this significance could be derived solely from the text of the treaty itself, not from ancillary considerations relating to a national law that may or may not be pertinent. $^{101}$

Turkish representatives had also contended that if Article 2 were to be applied without having recourse to national legislation of any kind, substantive inequalities in regards to the treatment of Turkish nationals would result, with state authorities in Turkey being left with no choice but to apply existing laws differently for different categories of citizens in Istanbul. This argument - a revealing but rather perplexing one - proved to have no traction whatsoever before the Court. For it was clear, the Court explained, that domestic laws of the kind that Turkish representatives had in mind must be applied to all citizens of a given country so long as they are applied to any. If a particular Turkish citizen was not subject to the exchange procedure, she would need to be accorded precisely the same rights as her fellow citizens. ${ }^{102}$

Finally, Turkey had put forward a rather bold claim to the effect that Turkish courts were competent to determine who was and was not "established" in Istanbul under Article 2. The Court pointed out that Article 12 granted full competence to the mixed commission in respect to the determination of nationality. ${ }^{103}$ Since exclusive jurisdiction in regards to this matter had been reserved to the commission, and since neither Greece nor Turkey had protested or made reservations to this stipulation at Lausanne, the commission must also have been granted the legal authority to confirm whether or not the conditions set out in Article 2

100 Ibid., at 21.

${ }^{101}$ For the argument in full, see ibid.

102 Ibid.

103 Convention of Lausanne, supra note 75 , at 83. 
for being "established" in Istanbul had been met. Hence, the commission was "alone competent to investigate, in each individual case, whether a Greek inhabitant of Constantinople is 'established' in conformity with Article 2 of the Convention and can be exempted from the compulsory exchange", 104

Interestingly, toward the conclusion of its analysis of the question concerning the meaning and scope of "established" in Article 2, the Court allowed itself to speculate to some degree on the motivations behind Turkey's claims. Though apparently somewhat hesitant to do this, ${ }^{105}$ the Court here suggested that Turkey's insistence on tethering Article 2 to domestic law was inspired by a felt need to buttress its sovereignty and independence, only recently secured and still evidently fragile. Here too the Court did not have much sympathy for the notion that Turkish sovereignty could be preserved only insofar as its legislative and jurisdictional powers were extended to Article 2. Since Turkey had entered into the Convention of Lausanne freely and with full knowledge of the consequences, it was now obligated to fulfill its commitments. In the Court's own words:

"The principal reason why the Turkish Delegation has maintained the theory of an implicit reference to local legislation appears to be that, in their opinion, a contrary solution would involve consequences affecting Turkey's sovereign rights. But, as the Court has already had occasion to point out ..., 'the right of entering into international engagements is an attribute of State sovereignty'. In the present case, moreover, the obligations of the contracting States are absolutely equal and reciprocal. It is therefore impossible to admit that a convention which creates obligations of this kind, construed

${ }^{104}$ Exchange of Greek and Turkish Populations, supra note 80, at 22. Comparisons can be drawn with international legal disputes brought before arbitral bodies. In 1928, for instance, the Franco-Turkish Mixed Arbitral Tribunal considered an interesting question of naturalization: a former Turkish national had acquired French citizenship, and Turkey contested the tribunal's jurisdiction over his claim by pointing to an 1869 Ottoman law which declared as null and void any attempt on the part of an Ottoman subject to seek naturalization in another state absent approval from Ottoman authorities. Rejecting this argument, the tribunal held that while Turkey was entitled to demand prior authorization for changes of nationality, a failure to comply with this requirement by a Turkish national would not bind any state apart from Turkey itself. In other words, "Turkish authorities were entitled to refuse to recognise the French naturalisation of the claimant", but "all other authorities, including the international tribunals, far from being bound in this matter by Turkish municipal legislation, were according to public international law under a duty to recognise the validity of the naturalisation". Apostolidis v. Turkish Government [1931] ADPILC 312. See also Julius Hatschek, An Outline of International Law, tr. C. A. W. Manning (London: G. Bell and Sons Ltd., 1930) at 154-5.

105 "As, however, Turkey, for reasons which do not concern the Court, did not wish to be compelled to retain at Constantinople Greeks who had migrated there after the date of the armistice of Mudros, the Convention refers not to the whole of the Greek population of Constantinople as it at present exists, but only to those members of it who were such also on October 30 ${ }^{\text {th }}, 1918$." Exchange of Greek and Turkish Populations, supra note 80, at 18 (emphasis mine). 
according to its natural meaning, infringes the sovereign rights of the High Contracting Parties." 106

More simply still, Huber wrote for the Court, "national sovereignty is not affected by the Convention in question". ${ }^{107}$ As an international act, the convention was an expression - and not an infringement - of sovereignty. ${ }^{108}$

At this point, the Court turned to the second of the two questions which had been posed to it - namely, that stemming from the need to fix the conditions under which persons seeking recognition as "established" inhabitants of Istanbul might actually secure such recognition. Here the Court attempted to draw a sharp distinction between those persons who were to be subjected to the exchange procedure and those who were not. For an individual to belong to the former rather than the latter class, her residence in Istanbul must, first, have preceded 30 October 1918, the date of the armistice between Allied and Ottoman forces, ${ }^{109}$ and, second, have been "of a lasting nature". ${ }^{110}$ As a result, "mere visitors" to the city were strictly excluded from the category of "les établis". 111

Naturally, the Court admitted that the "degree of stability" needed for this standard residence requirement to be satisfied was "incapable of exact definition". ${ }^{112}$ But it stressed that this "character of stability" comprised "the condition necessary to constitute "establishment" under Article $2 .{ }^{113}$ Similarly, it underscored the fact that it was in no position to assess, let alone resolve, the "complex problems" that arose from attempts to apply this standard of residence in certain situations, such as those in which some members of a given family satisfied it while

106 Ibid., at 21. The quoted passage was, of course, from the Case of the S. S. "Wimbledon" (United Kingdom v. Japan) PCIJ Rep. Series A No. 1 (1923) at 25. To preclude confusion, it should be noted that the Court erred in characterizing the Greek and Turkish members of the mixed commission as "delegates", and also in speaking of "delegations" to the commission. There were no such "delegates" or "delegations"; there were simply members of the commission, Greek, Turkish, and neutral. The Court would correct it error in its later opinion in Interpretation of the Greco-Turkish Agreement of December 15t, 1926 (Final Protocol, Article IV), Advisory Opinion, PCIJ Rep. Series B No. 16 (1928). See J. H. W. Verzijl, International Law in Historical Perspective, Vol. V (Leiden: Sijthoff, 1972) at 95.

107 Exchange of Greek and Turkish Populations, supra note 80, at 22.

108 For contemporaneous discussion of the jurisprudential context, see Ludwik Ehrlich, "L'interprétation des traités" 24 (1928-IV) RCADI 5 at 133-5.

109 For the text of the agreement, see Armistice Convention between Great Britain and the Allied Powers, and Turkey, signed at Mudros, October 30, 1918, 224 CTS 169.

${ }^{110}$ Exchange of Greek and Turkish Populations, supra note 80, at 23 and also 26.

111 Ibid., at 23.

112 Ibid.

113 Ibid., at 24. 
others did not. ${ }^{114}$ The Court was not in possession of enough materials and information to do what could only be done by the mixed commission. But it nonetheless adhered to its general definition of "establishment" as residence "of a lasting nature".

Though the Court did not belabour its analysis in this second portion of the advisory opinion, it did take time to address a specific argument which had been advanced by Turkey in the lead-up to the proceedings. Turkish members of the mixed commission had argued that all Greeks who had arrived in Istanbul after 18 October 1912 from districts that were now to be subject to the exchange ought themselves to be exchanged. The argument was creative but obviously ambitious. By using 18 October 1912 rather than 30 October 1918 as the determinative date, the Turks would have restricted the number of persons to which the Article 2 exception would apply quite severely. The Court had no patience for this. In its view, since Article 2 contained no stipulation, one way or the other, as to the places of origin of putative "établis", all that was required to determine who would be exempted from the exchange on this ground was to ascertain whether the individual under consideration satisfied the residence "of a lasting nature" criterion. In any event, the Article 2 exception for Istanbul's Greeks had been the "subject of long discussion at Lausanne", 115 and would have been rendered essentially ineffective had the Turks been able to persuade the commission or Court that their interpretation was correct. In other words, seeing as how one of the most essential objectives of Article 2 was to carve out exceptions to an otherwise comprehensive exchange of populations, limiting the ambit of the exception made available to "les établis" to the degree envisioned by the Turkish proposal would frustrate its basic purpose. ${ }^{116}$

\footnotetext{
114 Ibid.

115 According to Curzon, if the patriarchate's "spiritual and ecclesiastical prerogatives were" to have been "destroyed and the seat of the Patriarchate removed from Constantinople, a shock would" have been "delivered to the conscience of the whole civilised world". A representative of the Serb-Croat-Slovene state was even more effusive: "Its disappearance would create so great a moral void that a part of civilisation would seem to disappear with it; the conscience of people of all religions would be stirred, and no one could fail to make one observation, namely, that among all States of the world the Turkish State was the only one which denied a proper place to a venerable Christian institution, dating back many centuries, established at Constantinople long before the Caliphate itself, with an uninterrupted record of activity in the cause of civilisation and moral beneficence, even in the remote times of intolerance and religious persecution." TMC minutes (10 January 1923), in Lausanne Conference, supra note 15 , at $313,319,321$.

116 Exchange of Greek and Turkish Populations, supra note 80, at 25. Lauterpacht saw this argument from effectiveness as a key to treaty interpretation - and an important element in the PCIJ's jurisprudence. See Hersch Lauterpacht, "The Pact of Paris and the Budapest Articles of Interpretation" 20 (1934) TGS 178 at 187; and also Hersch Lauterpacht, The Development of International Law by the International Court, Rev. Ed. (London: Stevens \& Sons Ltd., 1958) at $69-88$.
} 
In sum, the Court's handling of the two questions is remarkable for its attempt to check what it regarded as unfounded Turkish claims to sovereignty in order to preserve the integrity of the international legal regime which had been established to coordinate the Greek-Turkish population exchange. Every Turkish attempt to restrict the number of persons to which the Article 2 exemption would apply - a typically semi-peripheral reaction to encroachment from without - is countered by the Court's decision to restrict Article 2's meaning and range of application - a characteristically internationalist compulsion to rein in parochial attachments to sovereignty and protect vulnerable populations. ${ }^{117}$ The substantive outcome, presented by the Court as derived from a strict adherence to both the letter and the spirit of the Convention of Lausanne, facilitated rapid implementation of the exchange by segregating those who were to be subjected to the procedure from those who were to be permitted to remain in Istanbul. The Court delineated the boundary between international and domestic law as crisply as possible. On the one hand, it reasoned, there were questions falling under the competence of the mixed commission as an institution constituted pursuant to an international treaty. On the other hand, there was the authority of domestic Turkish law and of the Turkish courts that were authorized to adjudicate disputes pursuant to such law. Though it did not rule out the possibility of engaging closely with municipal law in broadly similar cases, ${ }^{118}$ the Court held that the term "established" needed to be understood on its own terms rather than by reference to domestic legislation. This placed the whole matter squarely within the rubric of international public law, elevating what might otherwise have been a dispute relating to public administration within a particular state to the status of a proper question of international law. National sovereignty was to be curbed, and international stability thereby assured.

\section{Intervention and Interpretation}

117 Of course, this is a compulsion which has in many ways only gained wider appeal over time. For the strongest examination of the so-called "responsibility to protect", a set of wide-ranging interventionist practices currently undergoing intense juridification, see Anne Orford, International Authority and the Responsibility to Protect (Cambridge: Cambridge University Press, 2011), esp. chs. 1, 2.

118 Wilfred Jenks took note of this, arguing that " $[\mathrm{t}]$ he decision must therefore be regarded as an arrêt d'espèce which does not preclude the possibility that in some future case the Court may hold that some other treaty is to be interpreted in the light of the conceptions of some particular legal system". In his view, "[s]uch a ruling would not be unreasonable if the parties to the treaty had a common legal system and used in the treaty terms with a technical meaning in the law common to them". C. Wilfred Jenks, The Prospects of International Adjudication (London: Stevens \& Sons Ltd., 1964) at 578. 
It is important to note that the Court's sidelining of Turkish national legislation, while of legal merit, did not follow unequivocally from its own jurisprudence. Indeed, the Court's case law is somewhat ambiguous in cases where national laws were - or were claimed to be - at issue. Upper Silesia is often cited for the Court's declaration that "[f]rom the standpoint of International Law and of the Court which is its organ, municipal laws are merely facts which express the will and constitute the activities of States, in the same manner as do legal decisions or administrative measures". ${ }^{119}$ Yet Brazilian Federal Loans is also cited for its explicit engagement with the question of whether the Court is mandated to consider domestic jurisprudence in cases that touch upon or otherwise involve municipal law. ${ }^{120}$ In that case the Court explained that it "must pay the utmost regard to the decisions of the municipal courts of a country, for it is with the aid of their jurisprudence that it will be enabled to decide what are the rules which, in actual fact, are applied in the country the law of which is recognized as applicable in a given case". ${ }^{121}$ As "a tribunal of international law", it was thoroughly acquainted with international law, but was "not obliged also to know the municipal law of the various countries", and ought therefore to "endeavour to make a just appreciation of the jurisprudence of municipal courts" when this proved necessary. ${ }^{122}$ This position would receive support a decade later in Judge Hudson's separate opinion in The "Société Commerciale de Belgique". For Hudson, the Court was obligated to examine municipal law closely when a party to a dispute sought relief on the basis of it and it was deemed fitting to do so. However, it could not be assumed to be familiar with the content of any such law in advance and the party in question was therefore responsible for producing all requisite documents. ${ }^{123}$ Interestingly, Judges Pessôa and de Bustamante had both written dissenting opinions in Brazilian Federal Loans, arguing, among other things, that the general rule

${ }^{119}$ Case Concerning Certain German Interests in Polish Upper Silesia (The Merits) PCIJ Rep. Series A No. 7 (1926) at 19. Cf. Ole Spiermann, International Legal Argument in the Permanent Court of International Justice: The Rise of the International Judiciary (Cambridge: Cambridge University Press, 2005) at 277-80.

${ }^{120}$ See, e.g., Andreæ, supra note 98, at 37; Rosalyn Higgins, "The Role of National Courts in the International Legal Process" in Rosalyn Higgins, Problems and Process: International Law and How We Use It (Oxford: Clarendon, 1994$) 205$ at 205.

${ }^{121}$ Case Concerning the Payment in Gold of the Brazilian Federal Loans Issued in France (France $v$. Brazil) PCIJ Rep. Series A No. 21 (1929) at 124. See also Case Concerning the Payment of Various Serbian Loans Issued in France (France v. Kingdom of the Serbs, Croats, and Slovenes) PCIJ Rep. Series A No. 20 (1929) at 19.

122 Brazilian Federal Loans, supra note 121, at 124.

123 "Where municipal law is to be applied, a party which asks for relief should furnish to the Court the materials necessary for its finding the applicable law; and where as in this case no such materials are furnished to the Court, it would seem that the Court is not obliged to institute the research necessary for that purpose, that on the contrary it is free to deny the relief sought without instituting such a research." The "Société Commerciale de Belgique" (Belgium $v$. Greece) PCIJ Rep. Series A/B No. 78 (1939) at 184 (emphasis in original). 
articulated by the majority ought to be augmented. De Bustamante had maintained that the Court was duty-bound to "weigh the meaning and scope of such municipal laws in the light of its own particular views without allowing itself to be guided or influenced by the decisions of the national courts of the Parties in this respect". ${ }^{124}$ Likewise, Pessôa had agreed that the Court was "bound to set on one side the decisions of international tribunals and itself to give that interpretation of the legal provisions which may seem most just in the particular case". ${ }^{125}$ These dissents called for a significantly greater level of invasiveness than the majority opinion had: while the latter required the Court to consider the case law of municipal courts, a clear sign of deference to national sovereignty, the dissents demanded that the Court interpret municipal law without having recourse to any such case law, recruiting a far more internationalist vision of its jurisdiction and competence.

One cannot help but be struck by this divergence on a matter of such evident importance to inter-state dispute-resolution. In the Exchange opinion, the Court held itself obligated to determine not the most adequate technique for interpreting national legislation but the relevance, if any, of such legislation for treaty interpretation. But the less-than-univocal stance in respect to engagement with domestic case law one encounters in Brazilian Federal Loans casts some doubt on the Court's disavowal of domestic law in Exchange. After all, if the Court's position on the interpretation of municipal law was not entirely settled, with the majority and dissenting opinions in Brazilian Federal Loans disagreeing sharply on whether to engage municipal courts' own jurisprudence, the Court's outright bracketing of municipal law in the Exchange opinion would also seem to be open to some question. If the Court generally held firm to the view that prohibitions derived from treaties to which states have bound themselves cannot be regarded as violations of their sovereignty, ${ }^{126}$ with Anzilotti going so far as to argue that "a government should bear the consequences of the wording of a document for which it is responsible", ${ }^{127}$ it is also true that invocations of "natural meaning" were widely regarded by interwar jurists as amorphous and unreliable. As one scholar noted, "[i]t is sometimes difficult

\footnotetext{
124 Brazilian Federal Loans, supra note 121, at 135.

125 Ibid., at 151.

${ }^{126}$ For a typical articulation, see Jurisdiction of the European Commission of the Danube between Galatz and Braila, Advisory Opinion, PCIJ Rep. Series B No. 14 (1927) at 36. Cf. Robert R. Wilson, "Interpretation of Treaties: Contributions of the Permanent Court of International Justice to the Development of International Law" 24 (1930) ASIL Pd. 39 at 43 .

127 Case Concerning the Polish Agrarian Reform and the German Minority (Application for the Indication of Interim Measures of Protection) (Germany $v$. Poland) PCIJ Rep. Series A/B No. 58 (1933) at 182.
} 
to reconcile such pronouncements with the fact of serious disagreement which has occasioned the arbitrations or with honest differences of opinion among the arbitrators themselves". ${ }^{28}$

No "covert intent" to prime the pump of progressive internationalism need be "exposed" here: one has little reason to believe that the Court was insincere or duplicitous in holding that treaty interpretation demands rigorous attention to that which is specific to international law in the dispute at hand - or, even less plausibly, that it was engaged in "missionary activity" as such. The point, rather, is that the structural logic of the Court's handling of the question of "les établis" dictated an across-the-board rejection of Turkey's efforts to maximize its sovereign powers under Lausanne - a decisive defeat, in other words, for the ethno-nationalism which underwrote the position adopted by the Kemalists in The Hague and which humanitarians operating in the Near East throughout the 1910s and 20s struggled to contain. It was Turkey's international commitments, as enshrined in a properly construed Article 2, and not its domestic obligations, as embedded in the two domicile laws it took to the Court, that were at issue. Indeed, neither Turkey's specific motivations for diminishing the category of "les établis" nor its general concerns about sovereignty were pertinent: Turkey's "reasons" did "not concern the Court", and "national sovereignty" was "not affected by the Convention in question".

On the exceedingly few occasions when the Exchange opinion is remembered today, it is mentioned in passing as a mundane case of treaty interpretation involving a little-known but rather nasty episode in interwar history. Contextualized analysis of the opinion reveals a different story. Considered in light of the sharp rise in humanitarian interest in the Near East with the Great War, and of Turkey's reaction to this development, the opinion is less an illustration of a run-of-the-mill technique of treaty interpretation and more an exercise in fixing the boundary between national and international legal systems. Until recently an imperial power and still disposed to accord itself the same clout and authority, albeit now in a distinctly "antiimperial" register, Turkey refused to acquiesce in anything resembling neo-colonialism. Internationalizing the city of Istanbul, as Lorimer for one had suggested, ${ }^{129}$ or placing its Greek

128 Wilson, “Aspects”, supra note 98, at 542.

129 Lorimer's proposal was nothing if not ambitious: not only was Istanbul to be internationalized, but it was through this internationalization that the city was to come to serve as the "fulcrum" of "international government", with great and small powers alike sending large delegations to the city annually to legislate and codify new international law. James Lorimer, "Of the Denationalisation of Constantinople, and Its Devotion to International 
and other non-Muslim occupants under direct foreign or international protection, was, for example, simply not on the table. Yet, Turkey was very clearly not able to argue from a position of strength in this case. However vague the relevant rules of treaty interpretation may have been, the weight of legal opinion - not to mention that of political sympathy - was on Greece's side. Accordingly, Turkey pursued a distinctively semi-peripheral strategy, seeking to read down its international legal obligations and broaden the jurisdictional reach of its domestic laws and courts. ${ }^{130}$

As was its custom, the Court was methodical, making every effort to maintain a high level of analytical precision and judicial detachment throughout its judgment. But the basic assumptions underlying its reasoning bore a striking resemblance to the manner in which those associated with the humanitarian reconstruction of the Near East tended to understand their own work. Near East Relief and other organizations were committed to ensuring political stability and fostering economic growth in the region by facilitating the smoothest possible partition of the Ottoman Empire. First and foremost, this meant vigilant policing of nationalism. If the region were to be kept from descending into chaos, the army of humanitarians that had been assembled to assist the mixed commission by organizing refugee flows - flows which could also destabilize a Europe already perceived to be overburdened ${ }^{131}-$ and looking after the nuts-and-bolts work of resettlement believed that it would need to do everything in its power to contain ethno-nationalism. The Permanent Court, for its turn, sought to draw a sharp distinction between the domestic and international legal spheres in order to bypass Turkey's concerns that the exchange's method of implementation in Istanbul undermined its sovereignty. For the Court, the international legal regime which the Convention of Lausanne called for and which Nansen and others operationalized was indispensable for removing obstacles in the way of the exchange's unfolding.

Interests" [1876] in James Lorimer, Studies National and International, Being Occasional Lectures Delivered in the University of Edinburgh 1864-1889 (Edinburgh: William Green \& Sons, 1890) 121 at 128-9.

130 Turkey was given to arguing that treaties to which it was signatory were misunderstood by other parties at the time - a tendency famously demonstrated in the Lotus case and in the Court's less widely known opinion on the determination of the Iraqi border (Interpretation of Article 3, Paragraph 2, of the Treaty of Lausanne (Frontier between Turkey and Iraq)). On this see Charles Fairman, "The Interpretation of Treaties" 20 (1934) TGS 123 at 128. This would remain a characteristic feature of international legal thinking in the country for years to come; see generally Berdal Aral, “An Inquiry into the Turkish 'School' of International Law” 16 (2005) EJIL 769.

${ }^{131}$ In 1927 one commentator wrote that Europe was already "showing signs of becoming saturated". D. Christie Tait, "International Aspects of Migration" 6 (1927) Journal of the Royal Institute for International Affairs 25 at 28. 
Efforts to facilitate the reconstitution of the Near East were not limited to missionaryturned-humanitarian organizations like Near East Relief or institutions constituted under the Lausanne settlement like the mixed commission. They also informed, albeit in a less tangible and immediate form, the reasoning of a new international judiciary. Both parties complied with the Permanent Court's opinion, leading commentators to argue that, if nothing else, this at least was one case in which the League's dispute-resolution mechanisms had demonstrated their worth. ${ }^{132}$ At long last, the world would be rid of the kind of ethno-confessional hodgepodge which Ottoman decentralization had made possible and which Ernest Renan had lamented as early as 1882 as having brought about "la ruine de l'Orient". 133 There would be a Greek enclave in Istanbul, but its legal existence would be tightly circumscribed and its socio-political sustainability would be anything but obvious.

132 "The advice of the Court has been unquestioningly adopted by the parties. In this replanting of the population of the Near East, the machinery of the League has worked helpfully and constructively." Norman Bentwich, "The League of Nations and Refugees" 16 (1935) BYIL 114 at 124.

${ }^{133}$ Ernest Renan, Qu'est-ce qu'une nation? Conférence faite en Sorbonne, le 11 mars 1882, 2 ${ }^{\text {nd }}$ Ed. (Paris: Ancienne maison Michel Lévy frères, 1882) at 9. 


\section{CONCLUSION}

It is impossible to know with any certainty what Nansen might have been thinking when he set off for Istanbul in 1922. It is equally impossible to ascertain conclusively how much of the population exchange that subsequently unfolded grew out of his preferences. What is clear, though, is that Nansen's mission encapsulates nearly all of what made the Greek-Turkish exchange as structurally idiosyncratic, and as devastatingly effective, as it was. The pervasive desire among European lawyers and diplomats to "pacify" a region wracked by violence with an instrument tailored specifically to its history and local conditions; the odd mixture of arrogance and deference with which such lawyers and diplomats strained to twist and turn the tradition of minority protection they had inherited from their nineteenth-century forerunners, bringing its commitment to discipline ethno-nationalism to bear on a context in which it had only limited application; their willingness to work with, and in many cases simply acquiesce in the demands of, local nationalist elites determined to realize their own, often brutal, ambitions - as though in miniature, each of these elements, and others, found a home in Nansen's mission.

Close examination of the Greek-Turkish population exchange is indispensable for an appreciation of the origins and evolution of a distinct mechanism of nation-building under international law. What is perhaps most disconcerting of all, though, is the relative ease with which this mechanism came to be exported to other regions. Although it had its roots in the Near East, an archetypically semi-peripheral region, the population exchange travelled to other jurisdictions quite quickly, experiencing something of a successive "globalization" in the process. In the late 1930s and early 1940s, Nazi diplomats concluded dozens of transfer treaties with the Soviet Union and other central and east European states in the name of the Reich's "protective right" over its ethnic kin. ${ }^{1}$ Ethnic Germans in an Estonia or a Latvia, a Poland or a Romania, were to be given the right to "opt" for German citizenship - and thereby to submit to an ostensibly voluntary transfer to German territory. ${ }^{2}$ Immediately after the Second World War,

\footnotetext{
${ }^{1}$ Comparisons with the semi-periphery can be drawn here. As Vagts notes, German thinking about sovereignty "followed an analysis separate from, but parallel to, one that was then beginning to take shape in such countries as China and Turkey, which were pushing for the surrender of special extra-territorial rights that the western powers had imposed". Detlev F. Vagts, "International Law in the Third Reich" 84 (1990) AJIL 661 at 688.

${ }^{2}$ For what is still the strongest account of the wartime transfers, see Joseph B. Schechtman, European Population Transfers 1939-1945 (New York: Oxford University Press, 1946). See also Joseph B. Schechtmann, "The Option Clause in the Reich's Treaties on the Transfer of Populations" 38 (1944) AJIL 356. For a well-documented case
} 
the Allied Powers made heavy use of compulsory population transfer as a means of removing remaining ethnic Germans from central and eastern Europe. ${ }^{3}$ The partition of British India in 1947, which produced disputes regarding the regulation of population movements in addition to quandaries of state succession, ${ }^{4}$ was followed by the devastating expulsion of south Asians from Idi Amin's Uganda in 1972. ${ }^{5}$ This, in turn, was trailed by the ex post juridification of forced migration in Cyprus in $1974^{6}$ and in Bosnia in the early 1990s. ${ }^{7}$ In nearly every case, from Potsdam to Dayton, the Greek-Turkish population exchange has been cited as a principal precedent. ${ }^{8}$ Shortly before his death in 1942, none other than Politis would suggest that the wartime Nazi-Soviet transfer agreements, and the Reich's policy in regards to population movements more generally, derived directly from Lausanne. ${ }^{9}$

Today it is generally agreed that compulsory population transfers are illegal under international humanitarian law and international human rights law. Express prohibitions or language with roughly similar constructive effect can be found in the Universal Declaration of Human Rights, ${ }^{10}$ the Fourth Geneva Convention, ${ }^{11}$ the 1951 Refugee Convention, ${ }^{12}$ the

study, see Vladimir Solonari, Purifying the Nation: Population Exchange and Ethnic Cleansing in Nari-Allied Romania (Washington and Baltimore: Woodrow Wilson Center Press / Johns Hopkins University Press, 2009).

${ }^{3}$ So extensively, in fact, that leading scholars of minority protection would often remark on its growing popularity; see, e.g., Josef L. Kunz, "The Future of the International Law for the Protection of National Minorities" 39 (1945) AJIL 89 at 94. For two histories, see Alfred-Maurice de Zayas, A Terrible Revenge: The Ethnic Cleansing of the East European Germans (London: Palgrave Macmillan. 2006); Matthew Frank, Expelling the Germans: British Opinion and Post-1945 Population Transfer in Context (Oxford: Oxford University Press, 2007).

${ }^{4}$ For an early assessment, see Nicholas Mansergh, "The Partition of India in Retrospect" 21 (1965-6) International Journal 1. For a comprehensive recent study, see Yasmin Khan, The Great Partition: The Making of India and Pakistan (New Haven: Yale University Press, 2007).

${ }^{5}$ R. C. Chhangani, "Expulsion of Uganda Asians and International Law" 12 (1972) Indian Journal of International Law 400; Vishnu D. Sharma and Frank Wooldridge, "The Expulsion of the Ugandan Asians and Some Legal Questions Arising Therefrom" 7 (1974) Comparative and International Law Journal of Southern Africa 1.

${ }^{6}$ Christa Meindersma, "Population Exchanges: International Law and State Practice - Part 1" 9 (1997) International Journal of Refugee Law 335 at 351-64; Legal Issues Arising from Certain Population Transfers and Displacements on the Territory of the Republic of Cyprus in the Period since 20 July 1974, opinion prepared by a committee of jurists (Abi-Saab, Blumenwitz, Crawford, Dugard, Greenwood, Hafner, Orrego-Vicuña, Pellet, Schermers, and Tomuschat) (30 June 1999), available online at: http://www.cyprus.gov.cy/moi/pio/pio.nsf/All/A87E0AFB149260C3C2256D740028 F4A2/\$file/Opinion.pdf (last accessed 6 April 2011).

${ }_{7}$ See, e.g., Christopher M. Goebel, "Population Transfer, Humanitarian Law, and the Use of Ground Force in U.N. Peacemaking: Bosnia and Herzegovina in the Wake of Iraq" 25 (1992-3) NYUJILP 627.

8 See, e.g., Norman M. Naimark, Fires of Hatred: Ethnic Cleansing in Twentieth-Century Europe (Cambridge, MA: Harvard University Press, 2001) at 108, 110, 171; Dzovinar Kévonian, Réfugiés et diplomatie bumanitaire. Les acteurs européens et la scène proche-orientale pendant l'entre-deux-guerres (Paris: Publications de la Sorbonne, 2004) at 126-9.

${ }^{9}$ Nicolas Politis, "Le transfert des populations" 54 (1940) L'esprit international 185.

${ }^{10}$ Universal Declaration of Human Rights, GA Res. 217A (III), UN Doc. A/810 at 71 (1948), Arts. 9, 13, 15, at 734.

${ }^{11}$ Geneva Convention relative to the Protection of Civilian Persons in Time of War of August 12, 1949, 75 UNTS 287, Arts. 49, 147, at 318, 388. 
International Law Commission's Draft Code of Crimes against the Peace and Security of Mankind, ${ }^{13}$ and a number of other instruments. ${ }^{14}$ And international legal scholars have long characterized mass expulsions as an anomaly, a throwback to a cruder, less sophisticated age. ${ }^{15}$ Yet population transfer and broadly analogous forms of mass expulsion continue to be implemented or canvassed in a large number of states - among them China, ${ }^{16}$ Turkey, ${ }^{17}$ IsraelPalestine ${ }^{18}$ and, most recently, France. ${ }^{19}$ International legal legitimacy is nearly always sought for such exercises - particularly when those charged with justifying or excusing them prove able to couch them in "voluntary" terms. If a member of the Institut de droit international could argue in 1952 that "[d]u point de vue du droit international, il existe, en cette matière, liberté d'action absolue des Etats pourvu que les lois sur l'humanité ne soient pas violées", 20 so too could a UN rapporteur (and current judge of the International Court of Justice) argue as late as 1997 that in certain contexts "population transfers are lawful if they are non-discriminatory and are based upon the will of the people". ${ }^{21}$ As difficult as it may be to imagine circumstances in which

${ }^{12}$ Convention relating to the Status of Refugees, signed at Geneva, on 28 July 1951, 189 UNTS 150, Arts. 32-3, at 174, 176.

${ }^{13}$ Draft Code of Crimes against the Peace and Security of Mankind, 51 UN GAOR Supp. (No. 10) at 14, UN Doc. A/CN.4/L.532 (1996), Art. 18, at 6.

${ }^{14}$ For useful tabulations, see Jean-Marie Henckaerts, Mass Expulsion in Modern International Law and Practice (London: Nijhoff, 1995) at 206-9; Alfred de Zayas, "Forced Population Transfer" in Max Planck Encyclopedia of Public International Law, available online at: http://www.mpepil.com (last accessed 6 April 2011) at 2-4.

${ }_{15}$ See, e.g., M. Georges Scelle's contribution to Giorgio Balladore Pallieri, "Les transferts internationaux de populations" 44 (1952-II) AIDI 138 at 176, 176 (“Tout transfert de populations constitue une négation de l'éthique internationale moderne, base première de l'ordre juridique international."); Alfred de Zayas, "Collective Expulsions: Norms, Jurisprudence, Remedies" 16 (1997) Refugee Survey Quarterly 149 at 150 ("Collective expulsions $\ldots$ are an anachronism in the post-Second World War era ... [and] constitute an aberration and a threat to the peace that ought to be met by appropriate United Nations sanctions pursuant to Chapter VII of the UN Charter.").

${ }^{16}$ See, e.g., Michael Wills, "Population Transfer and Development in Tibet" Tibetan UN Advocacy (19 March 1995), available online at: http://www.tibetatun.org/un forums/wss/report19march05-2.html (last accessed 6 April 2011) (discussing the state-sponsored transfers of Han Chinese into Tibet).

${ }^{17}$ See, e.g., Gündüz Aktan, "Geleceğe Doğru (4)" Radikal (10 January 2006), available online at: http://www.radika 1.com.tr $/$ haber.php?haberno $=175378 \&$ tarih $=10 / 01 / 2006$ (last accessed 6 April 2011) (proposing an exchange of Turkish Kurds and Iraqi Turkmen).

${ }^{18}$ See, e.g., Barak Ravid, "Lieberman Presents Plans for Population Exchange at UN" Haaretæ.com (28 September 2010), available online at: http://www.haaretz.com/news/diplomacy-defense/lieberman-presents-plans-for-popula tion-exchange-at-un-1.316197 (last accessed 6 April 2011) (discussing the Israeli foreign minister's proposal that both populations and territories be exchanged as part of a final peace settlement).

${ }^{19}$ See, e.g., "Sarkozy dément avoir eu un «échange très violent» avec Barroso" Libération.fr (16 September 2010), available online at: http://www.liberation.fr/politiques/01012290581-sommet-europeen-echange-tres-violent-entre -sarkozy-et-barroso-sur-les-roms (last accessed 6 April 2011) (detailing France's expulsion of Roma and the reactions of EU officials).

${ }^{20}$ M. J. Spiropoulos' contribution to Pallieri, supra note 15, at 185, 186.

${ }^{21}$ Awn Shawkat Al-Khasawneh, Human Rights and Population Transfer: Final Report of the Special Rapporteur, UN Doc. E/CN.4/Sub.2/1997/23 (1997) at 19. 
whole peoples would submit willingly to community-wide movements, international law arguably continues to permit reliance upon "voluntary" transfers when such willingness is (or is deemed to have been) expressed "freely".

On a certain level, one can appreciate - if not acquiesce in - the popularity of population exchanges. Those entrusted with the task of administering territories home to significant national or religious conflicts have frequently looked to the population exchange as a necessary evil, the most humanitarian of the logistically viable options. Unsurprisingly, as the locus classicus of this form of nation-building, the Greek-Turkish exchange has enjoyed pride of place in most such cases. The Palestine Royal Commission, charged with offering recommendations for the administration of the British mandate over Palestine after the 1936-9 Arab revolts, lauded "the courage of the Greek and Turkish statesmen" involved in the exchange, declaring that relations between Greece and Turkey were "friendlier than they have ever been before" and suggesting that a similar exchange be undertaken as part of Palestine's partition. $^{22}$ Likewise, Churchill lavished praise on those responsible for the Greek-Turkish exchange when pressed on the merits of the proposed transfer of Germans out of central and eastern Europe: this "disentanglement" was "in many ways a success", and had, at any rate, "produced friendly relations between Greece and Turkey ever since". ${ }^{23}$ Time and again the Greek-Turkish experience has been cited favourably and brought to bear upon conflicts deemed structurally similar to that which confronted those at Lausanne.

None of this is entirely unintelligible. The Greek-Turkish exchange did, after all, go some way to resolve what had essentially been a protracted war-to-the-death between Greeks and Turks. Tensions between the two states would remain at a high level through the mid1920s, but were more than manageable during the two decades that followed. In 1930 Venizelos travelled to Ankara to sign a landmark "treaty of friendship", laying aside outstanding claims to

\footnotetext{
22 Palestine Royal Commission, Report, Cmd. 5479 (London: His Majesty's Stationery Office, 1937) at 390. For discussion, see Yossi Katz, "Transfer of Population as a Solution to International Disputes: Population Exchanges between Greece and Turkey as a Model for Plans to Solve the Jewish-Arab Dispute in Palestine during the 1930s" 11 (1992) Political Geography 55 at 58-62; Gregory H. Fox, Humanitarian Occupation (Cambridge: Cambridge University Press, 2008) at 137.

${ }^{23}$ Quoted in Alfred M. de Zayas, Nemesis at Potsdam: The Anglo-Americans and the Expulsion of the Germans, $2^{\text {nd }}$ Rev. Ed. (London: Routledge \& Kegan Paul Ltd., 1979) at 11. Speaking before the House of Commons in December 1944, Churchill would state that "expulsion is the method which, so far as we have been able to see, will be the most satisfactory and lasting. There will be no mixture of populations to cause endless trouble .... A clean sweep will be made. I am not alarmed at the prospect of the disentanglement of population, nor am I alarmed by these large transferences, which are more possible than they were before through modern conditions." Quoted in Naimark, supra note 8, at 110.
} 
properties lost or abandoned during the exchange. ${ }^{24}$ Relations between the two states improved to such a degree that Kemal felt comfortable bringing his long-awaited vision of a "Balkan Pact" to a head. Intended to cement regional ties in uti possidetis through mutual security guarantees, the pact was signed and ratified by four states - Greece, Romania, Turkey, and Yugoslavia - in 1934, the work, it was thought, of a more enlightened - and also more realistic - understanding of the region's needs and resources. ${ }^{25}$ Less consequential, but even more dramatic, is Venizelos' recommendation of none other than Kemal for the Nobel Peace Prize in $1934 .^{26}$

Very little of this proved to be lasting. The Balkan Pact, and similar plans for regional security integration, ${ }^{27}$ never bore fruit. By the early 1940s, the pact had shown itself to be toothless, a paper alliance flouted by espionage, growing rivalry, and shifting geopolitical dynamics. During the Second World War, Turkish authorities would introduce a "wealth tax", ostensibly to support the country's then feeble defense industry. Though short-lived and formally applicable to all Turkish citizens, this tax was applied discriminatorily to non-Muslims, stoking economic nationalization and further diluting the commercial power of minority groups. ${ }^{28}$ A second "Balkan Pact" was concluded between Greece, Turkey, and Yugoslavia in 1953. ${ }^{29}$ Remarkable though it may have been for its trans-ideological character (Tito's Yugoslavia maintained a notoriously uneasy relationship with the Soviet Union, while Greece

${ }^{24}$ Convention regarding the Final Settlement of the Questions resulting from the Application of the Treaty of Lausanne and of the Agreement of Athens relating to the Exchange of Populations, signed at Ankara, 10 June 1930, 108 LNTS 233. For analysis, see especially Damla Demirözü, “The Greek-Turkish Rapprochement of 1930 and the Repercussions of the Ankara Convention in Turkey" 19 (2008) Journal of Islamic Studies 309.

${ }_{25}$ Pact of Balkan Entente, and Protocol-Annex, signed at Athens, February 9 ${ }^{\text {th }}$, 1934, 153 LNTS 154, esp. Art. 1, at 155. For prospective and retrospective commentary, see M. A. Caloyanni, "The Balkan Union, the Balkan Conferences, and the Balkan Pact" 18 (1932) TGS 97 and 19 (1933) TGS 89; Hans W. Hartmann, "Les relations gréco-turques du traité de Lausanne au pacte d'Ankara, 1923-1933" 11 (1939) Les Balkans 333.

${ }^{26}$ For a brief record of the letter of recommendation to the Nobel Institute, see online at: http://nobelprize.org/n obelprizes/peace/nomination/nomination.php?action=show\&showid=2046 (last accessed 6 April 2011).

27 See, e.g., Theodore I. Geshkoff, Balkan Union: A Road to Peace in Southeastern Europe (New York: Columbia University Press, 1940).

28 Alexis Alexandris, The Greek Minority of Istanbul and Greek-Turkish Relations, 1918-1974 (Athens: Centre for Asia Minor Studies, 1972), ch. 7; Samim Akgönül, Türkiye Rumlar: Ulus-Devlet Că̆ından Küreselleșme Căğna Bir Azınluğın Yok Olus Süreci, tr. Ceylan Gürman (İstanbul: İletişim, 2007) at 114-49; Ayhan Aktar, "Varlık Vergisi Nasıl Uygulandı?" and "Varlık Vergisi Sırasında Gayri Menkul Satışları ile Servet Transferi: İstanbul Tapu Kayıtlarının Analizi" in Ayhan Aktar, Varlı Vergisi ve "Türklestirme" Politikalar (İstanbul: İletişim, 2000) 135 and 215 respectively; Rifat N. Bali, The "Varlk Vergisi" Affair: A Study on Its Legacy - Selected Documents (İstanbul: Isis Press, 2005).

${ }^{29}$ Treaty of Friendship and Collaboration, signed at Ankara, on February 28, 1953, 167 UNTS 21. 
and Turkey buttressed NATO's eastern flank under the shadow of the Truman Doctrine), ${ }^{30}$ it too revealed itself to be vulnerable to the vagaries of the Cold War and was terminated formally in 1960. Pogroms in Istanbul in 1955 accelerated the emigration of the "établis". "The Cyprus conflict came to the fore in full force during the same decade. Before long, large segments of the island's Greek-Cypriot population would begin to agitate for enosis, or union, with Greece; Greek-Cypriot paramilitaries committed to securing this union would target Turkish civilians and British soldiers alike; Turkish Cypriots would react by pressing for the island's taksim, or partition, and also by supporting their own paramilitaries; the two communities would subsequently struggle for years until a pro-enosis coup in Nicosia and support from an Athenian junta would bring the issue to a head in 1974, with Turkey intervening militarily to occupy the northern third of the island. As is well-known, numerous legal disputes have arisen from the mass expulsion of Greeks from Turkish-occupied territory, the ensuing transfer of many Turkish Cypriots to the north, the contested status of the "Turkish Republic of Northern Cyprus" declared unilaterally in 1983, and the difficulties engendered by Cyprus' accession to the European Union in 2004. ${ }^{32}$ Equally challenging has been complex legal wrangling in regards to maritime and airspace rights in the Aegean Sea. ${ }^{33}$

Examined in the light of these later developments, the Greek-Turkish exchange seems far less "successful" an enterprise than is still sometimes assumed. ${ }^{34}$ By grounding claims to statehood firmly in claims to nationhood, the exchange may have smoothed inter-state relations in the Near East to some degree. At the very least, it cannot be denied that the two states reconstructed by way of the Ottoman Empire's final dismemberment were possessed of a significant degree of ethno-national homogeneity, and that this was more than likely a key factor in minimizing the risk of a recurrence of total war. But it would be reckless to risk stronger,

\footnotetext{
30 Svetozar Rajak, “The Cold War in the Balkans, 1945-1956” in Melvyn P. Leffler and Odd Arne Westad, eds., The Cambridge History of the Cold War, Vol. I (Cambridge: Cambridge University Press, 2010) 198 at 215.

31 See, e.g., Alexandris, supra note 28, at 256-66; Akgönül, supra note 28, at 175-224; Nergis Canefe, "Modern Türk Toplumunda Zorunlu Göçlerin Mirası" in Nergis Canefe, Anavatandan Yavruvatana: Milliyetçilik, Bellek ve Aidiyet (İstanbul: İstanbul Bilgi Üniversitesi Yayınlar1, 2007) 77 at 105-6; Ali Tuna Kuyucu, "Ethno-religious 'Unmixing' of 'Turkey': 6-7 September Riots as a Case in Turkish Nationalism” 11 (2005) Nations and Nationalism 361.

32 Marios L. Evriviades, "The Legal Dimensions of the Cyprus Conflict" 10 (1975) Texas International Law Journal 227; Zaim M. Necatigil, The Cyprus Question and the Turkish Position in International Law, $2^{\text {nd }}$ Rev. Ed. (Oxford: Oxford University Press, 1993).

${ }^{33}$ Haralambos Athanasopulos, Greece, Turkey and the Aegean Sea: A Case Study in International Law (Jefferson, NC: McFarland \& Co., 2001); Yücel Acer, The Aegean Maritime Disputes and International Law (Aldershot: Ashgate, 2003).

34 The relevant social science literature is replete with arguments to the effect that even now population transfers are, on balance, preferable to most other responses to "ethnic conflict". See, e.g., Chaim D. Kaufmann, "When All Else Fails: Ethnic Population Transfers and Partitions in the Twentieth Century" 23 (1998) International Security 120.
} 
more sweeping conclusions regarding the normative value, or even functional viability, of unilateral transfers and bilateral exchanges. As though the chequered history of Greek-Turkish relations in the remainder of the twentieth century were not enough to militate against such inferences, the fact that much of the scholarship produced about the exchange, by Greek and Turkish scholars alike, has been dominated by misleading representations of the historical record, and that this continues to be the case despite efforts by critical historians on both sides, ${ }^{35}$ testifies to the resilience of ethno-nationalist rivalry. Indeed, it is arguable that, while ameliorative of conflict in the short term, the Greek-Turkish exchange actually exacerbated such rivalry over the medium- to long-term: in the place of two states with "mixed" populations and juridico-political institutions equipped to respond to disputes arising from such heterogeneity, there were now two nation-states forged through war and expulsion, each with a citizenry that much more conscious and resentful of the other. What is more, the assumption that a particular technique of conflict-resolution, with a unique provenance and trajectory of development, might offer a ready-made solution to conflicts that emerge under different conditions and are mediated by different forces is quite evidently questionable. Even if the exchange were to have been a genuine "success" (however exactly this might be defined), it is far from clear that one could infer that large-scale population movements, whether unilateral or bilateral, would make for appropriate responses to crises at other times and in other places.

Given the need for scepticism in regards to the Greek-Turkish precedent, the ongoing popularity of various forms of population transfer, and of the technocratic ethos which makes it possible, seems stranger still. From a comparatively marginal response to full-scale conflict, limited in application to a region in which leading actors frequently saw themselves as engaged in brutal, life-or-death struggles, to a more or less "universal" mechanism, deemed transferable to all manner of contexts, the genealogy of the transfer mechanism is by and large a tale of growing fascination. Leading jurists and policymakers after 1945 often regarded the transfer as a legitimate competitor to group rights and individualistic human rights. Raphael Lemkin,

\footnotetext{
35 For commendably honest critique, see, e.g., Georgios Nakracas, Anadolu ve Rum Göcmenlerin Kökeni: 1922 Emperyalist Yunan Politikasi ve Anadolu Felaketi, tr. İbram Onsunoğlu (İstanbul: Belge, 2000); Lambros Baltsiotis, "Yunanistan ve Türkiye'de Muhacirlik ve Nüfus Mübadeleleri: İki Farklı Anlatım ve Yorumun Oluşma Şartları ve Sonuçları", tr. Halil Mustafa, in Müfide Pekin, ed., Yeniden Kurulan Yaşamlar: 1923 Türk-Yunan Zorunlu Nüfus Mübadelesi (İstanbul: İstanbul Bilgi Üniversitesi Yayınları, 2005) 401; Onur Yıldırım, Diplomacy and Displacement: Reconsidering the Turco-Greek Exchange of Populations, 1922-1934 (New York: Routledge, 2006), esp. at 18-9; Ayhan Aktar and Damla Demirözü, "Yunan Tarihyazımında Mübadele ve Göç" 22 (2006) Kebikę̧ 85.
} 
celebrated author of the Genocide Convention, may, for instance, have clung steadfast to minority protection, but the influential activist and refugee scholar Joseph Schechtman generally considered transfers to be the only truly viable solution to ethno-nationalist conflict. ${ }^{36}$ Rather than discrediting their usage, wartime Nazi and Allied transfers seem to have convinced many that "eliminating minorities was simply a necessary part of modern nationalism and modern internationalism alike". ${ }^{37}$ Though compulsory transfers have since been criminalized, lawyers employed by states seeking to gain acceptance - if not approbation - for transfers work regularly to persuade their audiences that such movements accord with popular will. Quite apart from whether the distinction between compulsory and voluntary movements is actually tenable (it is hard to speak of a "right of option", for instance, when the individual in whom it is supposed to vest belongs to a community that is subject to systematic and widespread persecution), the fact that the Greek-Turkish exchange was not as effective at constraining ethno-nationalism as has traditionally been thought should give us some pause when evaluating such efforts at legitimation.

If we are to understand the continuing allure of at least some elements of population transfer, we must come to grips with its origins in a semi-peripheral region with a specific set of entrenched traditions, institutions, grievances, and aspirations. Regardless of where this or that group of interwar jurists may have stood on the question of legality, the feeling that conflicts in the Near East called for measures distinct from the kind of minority protection that had become routine in Europe after 1919 but not as heavy-handed as a full-blown mandatory regime was widely shared. Even if they were not entirely comfortable with it, lawyers and politicians alike touted the exchange as a necessary step forward. We have grown accustomed in recent years to hearing that the states of southeastern Europe have come to serve as a kind of "laboratory" for state-building and humanitarian intervention. ${ }^{38}$ Perhaps it should come as no surprise that one of the most ambitious techniques of nation-building should have had its origins in this very same region.

\footnotetext{
${ }^{36}$ On this see especially Mark Mazower, No Enchanted Palace: The End of Empire and the Ideological Origins of the United Nations (Princeton: Princeton University Press, 2009), ch. 3.

${ }^{37}$ Ibid., at 107 and also 137.

38 See, e.g., Mariella Pandolfi, "From Paradox to Paradigm: The Permanent State of Emergency in the Balkans" in Didier Fassin and Mariella Pandolfi, eds., Contemporary States of Emergency: The Politics of Military and Humanitarian Interventions (New York: Zone Books, 2010) 153 at 168; David Chandler, International Statebuilding: The Rise of PostLiberal Governance (Abingdon: Routledge, 2010), ch. 5.
} 


\section{BIBLIOGRAPHY}

\section{League of Nations Documents}

"Deportation of Women and Children in Turkey and Neighbouring Countries", C. 440 M. 317. 1921. IV., 3 (1922) LNOJ 61.

L'établissement des réfugiés en Grèce (Genève: Publications de la Société des Nations, 1926).

Nansen, Fridtjof. "Reciprocal Exchange of Racial Minorities between Greece and Turkey", C. 736. N447. 1922, 4 (1923) LNOJ 126.

---. "Relief Measures for Refugees in Greece and Asia Minor", C. 736(a). M447(a). 1922, 4 (1923) LNOJ 133.

---. "Report by Dr. Fridtjof Nansen of an Enquiry by a Committee of Experts Made in Armenia under the Auspices of the International Labour Office (July 1925)" in Scheme for the Settlement of Armenian Refugees: General Survey and Principal Documents, C. 699. M. 264. 1926. IV. (Geneva: League of Nations, 1927) 65.

"Notification by the German Government of its Intention to Withdraw from the League of Nations", C. 605. M. 282. 1933. V., 15 (1934) LNOJ 16.

Protection of Linguistic, Racial and Religious Minorities by the League of Nations: Provisions Contained in the V arious International Instruments at Present in Force, C. L. 110. 1927. I. (Geneva: League of Nations, 1927).

Protection of Linguistic, Racial or Religious Minorities by the League of Nations: Resolutions and Extracts from their Minutes of the Council, Resolutions and Reports adopted by the Assembly, relating to the Procedure to be followed in Questions concerning the Protection of Minorities, C. 24. M. 18. 1919. I. (Geneva: League of Nations, 1929).

"Question of the Expulsion of the CEcumenical Patriarch - Expulsion of the CEcumenical Patriarch from Constantinople. Appeal by the Greek Government under Paragraph 2 of Article 11 of the Covenant", C. 57. M. 30. 1925. VII., 6 (1925) LNOJ 579.

"Question of the Expulsion of the CEcumenical Patriarch - Letter and Memorandum from the Greek Government to the Secretary-General of the League”, C. 211. M. 70. 1925. VII., 6 (1925) LNOJ 637.

"Question of the Expulsion of the CEcumenical Patriarch - Letter from the Turkish Government to the Secretary-General of the League, Submitted to the Council on March $14^{\text {th }}$, 1925”, C. 160. 1925. VII., 6 (1925) LNOJ 579.

“Relief for Refugees from Asia Minor", C. 211 M. 70. 1925. VII., 3 (1922) LNOJ 1140. 
"Report of the International Committee of Jurists Entrusted by the Council of the League of Nations with the Task of Giving an Advisory Opinion upon the Legal Aspects of the Aaland Islands Question”, 3 (1920) LNOJ Spec. Sup. 3.

"Resolution Adopted by the Council on September 5 ${ }^{\text {th }}$, 1923", reproduced in Protection of Linguistic, Racial or Religious Minorities by the League of Nations: Resolutions and Extracts from their Minutes of the Council, Resolutions and Reports adopted by the Assembly, relating to the Procedure to be followed in Questions concerning the Protection of Minorities, C. 24. M. 18. 1919. I. (1929) 7.

\section{United Nations Documents}

Al-Khasawneh, Awn Shawkat. Human Rights and Population Transfer: Final Report of the Special Rapporteur, UN Doc. E/CN.4/Sub.2/1997/23 (1997).

Capotorti, Francesco. Study on the Rights of Persons Belonging to Ethnic, Religious and Linguistic Minorities, UN Doc. E/CN.4/Sub.2/384 (1991).

Draft Articles on Responsibility of States for Internationally Wrongful Acts, with Commentaries, in Report of the International Law Commission on the Work of Its Fifty-Third Session, UN GAOR, $56^{\text {th }}$ Sess., Supp. No. 10, UN Doc. A/56/10 (2001).

\section{Travaux préparatoires}

[France] Ministère des affaires étrangères, Conférence de Lausanne sur les affaires $d u$ Proche-Orient (1922-1923). Recueil des Actes de la Conférence, Six Vols. (Paris: Imprimerie nationale, 1923).

[Great Britain] Lausanne Conference on Near Eastern Affairs (1922-1923): Records of Proceedings and Draft Terms of Peace, Cmd. 1814 (London: His Majesty's Stationery Office, 1923).

\section{Legal Opinions}

Legal Issues Arising from Certain Population Transfers and Displacements on the Territory of the Republic of Cyprus in the Period since 20 July 1974, legal opinion prepared for the Republic of Cyprus by a council of jurists (Georges Abi-Saab, Dieter Blumenwitz, James Crawford, John Dugard, Christopher Greenwood, Gerhard Hafner, Francisco Orrego-Vicuña, Alain Pellet, Henry Schermers, and Christian Tomuschat) (30 June 1999), available online at: http://www.cyprus.go v.cy/moi/pio/pio.nsf/All/A87E0AFB149260C3C2256D740028F4A2/\$file/Opinion.pdf (last accessed 6 April 2011).

\section{Governmental Reports and Diplomatic Memoranda}


[Allied and Associated Powers] Commission on the Responsibility of the Authors of the War and on Enforcement of Penalties, Report Presented to the Preliminary Peace Conference, reproduced in 14 (1920) AJIL Sup. 95.

[Bulgaria] Délégation bulgare à la Conférence de la Paix, Exposé sur la question de la Thrace occidentale (n.p.: 1919).

[Great Britain] Palestine Royal Commission, Report, Cmd. 5479 (London: His Majesty's Stationery Office, 1937).

[United States] Report of the American Section of the International Commission on Mandates in Turkey, reproduced in Papers Relating to the Foreign Relations of the United States: The Paris Peace Conference 1919, Vol. XII (Washington: United States Government Printing Office, 1947) 751.

\section{Popular Publications}

Aktan, Gündüz. "Geleceğe Doğru (4)" Radikal (10 January 2006), available online at: http://ww w.radikal.com.tr/haber.php?haberno $=175378 \& \operatorname{tarih}=10 / 01 / 2006$ (last accessed 6 April 2011).

Near East Foundation. "Near East Foundation Celebrates $90^{\text {th }}$ Year; First U.S. International Development Organization; Pioneer of American Philanthropy Abroad", available online at: htt p://www.neareast.org/images/uploads/90thanniv 1.pdf (last accessed 6 April 2011).

Ravid, Barak. "Lieberman Presents Plans for Population Exchange at UN" Haaretr.com (28 September 2010), available online at: http://www.haaretz.com/news/diplomacy-defense/lieber man-presents-plans-for-population-exchange-at-un-1.316197 (last accessed 6 April 2011).

"Sarkozy dément avoir eu un «échange très violent» avec Barroso" Libération.fr (16 September 2010), available online at: http://www.liberation.fr/politiques/01012290581-sommet-europeenechange-tres-violent-entre-sarkozy-et-barroso-sur-les-roms (last accessed 6 April 2011).

Wills, Michael. "Population Transfer and Development in Tibet" Tibetan UN Advocacy (19 March 1995), available online at: http://www.tibetatun.org/un forums/wss/report19march052.html (last accessed 6 April 2011).

\section{Secondary Literature}

Abdy, J. T., ed. Kent's Commentary on International Law, $2^{\text {nd }}$ Rev. Ed. (Cambridge: Deighton, Bell, and Co., 1878).

Abou-El-Haj, Rifa'at 'Ali. Formation of the Modern State: The Ottoman Empire, Sixteenth to Eighteenth Centuries, $2^{\text {nd }}$ Ed. (Syracuse: Syracuse University Press, 2005).

Acer, Yücel. The Aegean Maritime Disputes and International Law (Aldershot: Ashgate, 2003). 
Adanır, Fikret. "Turkey's Entry into the Concert of Europe" 13 (2005) European Review 395. --- and Hilmar Kaiser. "Migration, Deportation, and Nation-Building: The Case of the Ottoman Empire" in René Leboutte, ed., Migrations et migrants dans une perspective historique: permanences et innovations (Brussels: P. I. E. - Peter Lang, 2000) 273.

Ahmad, Feroz. The Young Turks: The Committee of Union and Progress in Turkish Politics, 1908-1914 (Oxford: Clarendon Press, 1969).

---. "Unionist Relations with the Greek, Armenian, and Jewish Communities of the Ottoman Empire, 1908-1914" in Benjamin Braude and Bernard Lewis, eds., Christians and Jews in the Ottoman Empire: The Functioning of a Plural Society, Vol. I (New York: Holmes \& Meier, 1982) 401. ---. "Ottoman Perceptions of the Capitulations 1800-1914" 11 (2000) Journal of Islamic Studies 1.

Akarlı, Engin Deniz. "The Tangled Ends of an Empire and Its Sultan" in Leila Tarazi Fawaz and C. A. Bayly, eds., Modernity and Culture: From the Mediterranean to the Indian Ocean (New York: Columbia University Press, 2002) 261.

Akçam, Taner. A Shameful Act: The Armenian Genocide and the Question of Turkish Responsibility, tr. Paul Bessemer (New York: Metropolitan Books, 2006).

Akçura, Yusuf. Ü̧̧ Tařı Siyaset (Ankara: Türk Tarih Kurumu, 1976 [1904]).

Akgönül, Samim. "Les vestiges du système ottoman dans le traitement des minorités en Grèce et en Turquie" in Sylvie Gangloff, ed., La perception de l'héritage ottoman dans les Balkans (Paris: L'Harmattan, 2005).

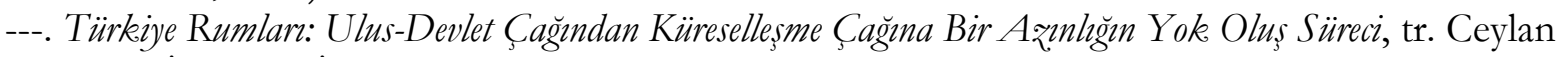
Gürman (İstanbul: İletişim, 2007).

Aksakal, Mustafa. The Ottoman Road to War in 1914: The Ottoman Empire and the First World War (Cambridge: Cambridge University Press, 2008).

Aktar, Ayhan. "Nüfusun Homojenleştirilmesi ve Ekonominin Türkleştirilmesi Sürecinde Bir Aşama: Türk-Yunan Nüfus Mübadelesi 1923-1924" in Ayhan Aktar, Varlı Vergisi ve "Türkleștirme" Politikealar (İstanbul: İletişim, 2000) 17.

---. "Cumhuriyetin İlk Yıllarında Uygulanan 'Türkleştirme' Politikaları" in Ayhan Aktar, Varlık Vergisi ve "Türklestirme" Politikalar (İstanbul: İletişim, 2000) 101.

---. "Varlık Vergisi Nasıl Uygulandı?" in Ayhan Aktar, Varlık Vergisi ve "Türklestirme" Politikalar (İstanbul: İletişim, 2000) 135.

---. "Varlık Vergisi Sırasında Gayri Menkul Satışları ile Servet Transferi: İstanbul Tapu Kayıtlarının Analizi" in Ayhan Aktar, Varlı Vergisi ve "Türkleștirme" Politikalar (İstanbul: İletişim, 2000) 215.

---. "Türk-Yunan Nüfus Mübadelesi ve Diplomasi” in Ayhan Aktar, Türk Milliyetçiliüi, Gayrimüslimler ve Ekonomik Dönüşüm (İstanbul: İletişim, 2006) 99.

--- and Damla Demirözü. "Yunan Tarihyazımında Mübadele ve Göç” 22 (2006) Kebikeç 85.

Albrecht-Carrié, René. A Diplomatic History of Europe since the Congress of Vienna (New York: Harper \& Brothers, 1958). 
Alexandris, Alexis. The Greek Minority of Istanbul and Greek-Turkish Relations, 1918-1974 (Athens: Centre for Asia Minor Studies, 1972).

Allain, Jean. International Law in the Middle East: Closer to Power than Justice (Aldershot: Ashgate, 2004).

Altuğ, Y1lmaz M. Turkey and Some Problems of International Law (İstanbul: Yenilik Basımevi, 1958).

Al-Zaibag, Abdul-Malik Salim. “The Mosul Boundary Question”, M.A. thesis, Tufts University (1948).

Anand, R. P. "Family of 'Civilized' States and Japan: A Story of Humiliation, Assimilation, Defiance and Confrontation" in R. P. Anand, Studies in International Law and History: An Asian Perspective (Leiden: Nijhoff, 2004) 24.

Anderson, Perry. Lineages of the Absolutist State (London: Verso, 1979).

Andrex, J. P. Fockema. An Important Chapter from the History of Legal Interpretation: The Jurisdiction of the First Permanent Court of International Justice (1922-1940) (Leyden: Sijthoff, 1948).

Anghie, Antony. Imperialism, Sovereignty and the Making of International Law (Cambridge: Cambridge University Press, 2005).

Aral, Berdal. “An Inquiry into the Turkish 'School' of International Law” 16 (2005) EJIL 769.

Argyll, George Douglas Campbell. The Eastern Question; From the Treaty of Paris 1856 to the Treaty of Berlin 1878, and to the Second Afghan War, Vol. I (London: Strahan \& Co., 1879).

Ar1, Kemal. Büyülk Mübadele: Türkiye'ye Zorunlu Göç (1923-1925) (İstanbul: Tarih Vakf1 Yurt Yayınlar1, 1995).

Armstrong, S. W. "The Doctrine of the Equality of Nations in International Law and the Relation of the Doctrine to the Treaty of Versailles" 14 (1920) AJIL 540.

Arnakis, G. Georgiades. "The Greek Church of Constantinople and the Ottoman Empire" 24 (1952) Journal of Modern History 235.

Arrighi, Giovanni. The Long Twentieth Century: Money, Power, and the Origins of Our Times (London: Verso, 1994).

Artinian, Vartan H. "The Formation of Catholic and Protestant Millets in the Ottoman Empire" 28 (1975) Armenian Review 3.

Athanasopulos, Haralambos. Greece, Turkey and the Aegean Sea: A Case Study in International Law (Jefferson, NC: McFarland \& Co., 2001). 
Attrep, Abe. “"A State of Wretchedness and Impotence': A British View of Istanbul and Turkey, 1919” 9 (1978) International Journal of Middle East Studies 1.

Avagyan, Arsen. "Kemalistler, İttihatçllar ve Bolşevikler: Kurtuluş Şavaşı'nda Ankara-Sovyet İlişkileri” 159 (2007) Toplumsal Tarih 14.

Aydin, Cemil. The Politics of Anti-Westernism in Asia: Visions of World Order in Pan-Islamic and PanAsian Thought (New York: Columbia University Press, 2007).

Åkermark, Athanasia Spiliopoulou. Justifications of Minority Protection in International Law (The Hague: Kluwer, 1997).

Bağ1ş, Ali İhsan. Osmanl Ticaretinde Gayrî Müslimler: Kapitülasyonlar - Avrupa Tüccarlar - Beratlı Tüccarlar - Hayriye Tüccarlar (1750-1839) (Ankara: Turhan Kitabevi, 1983).

Bain, J. Arthur. Life and Adventures of Nansen, the Great Arctic Explorer (London: The Walter Scott Publishing Co., 1897).

Bali, Rifat N. The "Varlık Vergisi" Affair: A Study on Its Legacy - Selected Documents (İstanbul: Isis Press, 2005).

Baltsiotis, Lambros. "Yunanistan ve Türkiye'de Muhacirlik ve Nüfus Mübadeleleri: İki Farklı Anlatım ve Yorumun Oluşma Şartları ve Sonuçları", tr. Halil Mustafa, in Müfide Pekin, ed., Yeniden Kurulan Yaşamlar: 1923 Türk-Yunan Zorunlu Nüfus Mübadelesi (İstanbul: İstanbul Bilgi Üniversitesi Yayınları, 2005) 401.

Barlas, Dilek. "Friends or Foes? Diplomatic Relations between Italy and Turkey, 1923-36" 36 (2004) International Journal of Middle East Studies 231.

Barton, James L. "A Program for the Near East" (1923) 108 Annals of the American Academy of Political and Social Science 153.

---. Story of Near East Relief (1915-1930): An Interpretation (New York: Macmillan, 1930).

--- ed. "Turkish Atrocities": Statements of American Missionaries on the Destruction of Christian Communities in Ottoman Turkey, 1915-1917 (Ann Arbor, MI: Gomidas Institute, 1998).

Barutciski, Michael. "Les transferts de populations quatre-vingts ans après la Convention de Lausanne” 41 (2003) Canadian Yearbook of International Law 271.

Bassiouni, M. Cherif. Crimes against Humanity in International Criminal Law, $2^{\text {nd }}$ Rev. Ed. (The Hague: Kluwer, 1999).

---. Crimes against Humanity: Historical Evolution and Contemporary Application (Cambridge: Cambridge University Press, 2011).

Batalas, Achilles. "Send a Thief to Catch a Thief: State-Building and the Employment of Irregular Military Formations in Mid-Nineteenth-Century Greece" in Diane E. Davis and 
Anthony W. Pereira, eds., Irregular Armed Forces and Their Role in Politics and State Formation (Cambridge: Cambridge University Press, 2003) 149.

Baty, Thomas. International Law in Twilight (Tokyo: Maruzen Co., 1954).

Bayly, C. A. "Distorted Development: The Ottoman Empire and British India, circa 17801916" 27 (2007) Comparative Studies of South Asia, Africa and the Middle East 332.

Becker Lorca, Arnulf. "Universal International Law: Nineteenth-Century Histories of Imposition and Appropriation” 51 (2010) HILJ 475.

Bell, Duncan and Casper Sylvest. "International Society in Victorian Political Thought: T. H. Green, Herbert Spencer, and Henry Sidgwick” 3 (2006) Modern Intellectual History 207.

Belli, Mihri. Türkiye-Yunanistan Nüfus Mübadelesi: Ekonomik Açıdan Bir Bakıss, tr. Müfide Pekin (İstanbul: Belge, 2006).

Bennett, G. H. British Foreign Policy during the Curzon Period, 1919-1924 (London: St. Martin's Press, 1995).

Benton, Lauren. Law and Colonial Cultures: Legal Regimes in World History, 1400-1900 (Cambridge: Cambridge University Press, 2002).

---. A Search for Sovereignty: Law and Geography in European Empires, 1400-1900 (Cambridge: Cambridge University Press, 2010).

Bentwich, Norman. "The Abrogation of the Turkish Capitulations" 5 (1923) Journal of Comparative Legislation and International Law 182.

---. "Nationality in Mandated Territories Detached from Turkey" 7 (1926) BYIL 97.

---. "The League of Nations and Refugees" 16 (1935) BYIL 114.

Berkes, Niyazi. The Development of Secularism in Turkey (Montreal: McGill University Press, 1964).

Berktay, Halil. "Three Empires and the Societies They Governed: Iran, India and the Ottoman Empire" in Halil Berktay and Suraiya Faroqhi, eds., New Approaches to State and Peasant in Ottoman History (London: Frank Cass, 1992) 242.

Berman, Nathaniel. "A Perilous Ambivalence: Nationalist Desire, Legal Autonomy, and the Limits of the Interwar Framework" 33 (1992) HILJ 353.

---. "Modernism, Nationalism, and the Rhetoric of Reconstruction" 4 (1992) Yale Journal of Law and the Humanities 351.

---. "But the Alternative is Despair': European Nationalism and the Modernist Renewal of International Law” 106 (1993) Harvard Law Review 1792.

---. "Against the Wrong and the Dead: A Genealogy of Left/MPM" 22 (2001) Cardoro Law Review 1005. 
Bernard, Mountague. On the Principle of Non-Intervention: A Lecture Delivered in the Hall of All Souls' College (Oxford: J. H. and Jas. Parker, 1860).

Berridge, G. R. Gerald Fitzmaurice (1865-1939), Chief Dragoman of the British Embassy in Turkey (Leiden: Nijhoff, 2007).

---. British Diplomacy in Turkey, 1583 to the Present: A Study in the Evolution of the Resident Embassy (Leiden: Nijhoff, 2009).

Beşikçi, İsmail. Tunceli Kanunu (1935) ve Dersim Jenosidi (İstanbul: Belge Yayınlar1, 1990).

Bhuta, Nehal. “Against State-Building” 15 (2008) Constellations 517.

[Bilsel], M. Cemil. Lozan, Two Vols. (İstanbul: Ahmet İhsan Matbaas1, 1933).

Blaisdell, Donald C. European Financial Control in the Ottoman Empire: A Study of the Establishment, Activities, and Significance of the Administration of the Ottoman Public Debt (New York: Columbia University Press, 1929).

Blanchard, Raoul. “The Exchange of Populations between Greece and Turkey" 15 (1925) Geographical Review 449.

Bloxham, Donald. The Great Game of Genocide: Imperialism, Nationalism, and the Destruction of the Ottoman Armenians (Oxford: Oxford University Press, 2005).

Boratav, Korkut. Türkiye'de Devletçilike, $2^{\text {nd }}$ Ed. (Ankara: İmge, 2006).

Borella, François. "Le passeport” 64 (1960) RGDIP 301.

Bourdieu, Pierre. Outline of a Theory of Practice, tr. Richard Nice (Cambridge: Cambridge University Press, 1977).

---. "The Force of Law: Toward a Sociology of the Juridical Field", tr. Richard Terdiman, 38 (1987) Hastings Law Journal 805.

---. The Logic of Practice, tr. Richard Nice (Stanford: Stanford University Press, 1990).

--- and Jean-Claude Chamboredon and Jean-Claude Passeron. The Craft of Sociology: Epistemological Preliminaries, ed. Beate Krais and tr. Richard Nice (Berlin: Walter de Gruyter, 1991).

--- and Loïc J. D. Wacquant. An Invitation to Reflexive Sociology (Chicago: University of Chicago Press, 1992).

---. The State Nobility: Elite Schools in the Field of Power, tr. Lauretta C. Clough (Stanford: Stanford University Press, 1996).

---. "Rethinking the State: Genesis and Structure of the Bureaucratic Field", tr. Loïc J. D. Wacquant and Samar Farage, in Pierre Bourdieu, Practical Reason: On the Theory of Action (Stanford: Stanford University Press, 1998) 35.

---. Pascalian Meditations, tr. Richard Nice (Stanford: Stanford University Press, 2000).

---. "From the King's House to the Reason of State: A Model of the Genesis of the Bureaucratic Field" in Loïc Wacquant, ed., Pierre Bourdieu and Democratic Politics: The Mystery of Ministry (Cambridge: Polity, 2005) 29. 
Bourquin, Maurice. Dynamism and the Machinery of International Institutions: A Critical Study of a Twenty Years' Experiment (Geneva: Geneva Research Centre, 1940).

Bowen, Herbert Wolcott. International Law: A Simple Statement of Its Principles (New York: G. P. Putnam's Sons, 1896).

Bowman, Isaiah. "Constantinople and the Balkans" in Edward M. House and Charles Seymour, eds., What Really Happened at Paris: The Story of the Peace Conference, 1918-1919 (New York: Charles Scribner's Sons, 1921) 140.

---. "A Note on the Political Map of Turkey" 1 (1922-3) Foreign Affairs 159.

Bozarslan, Hamit. "L'alévisme et l'impossible équation du nationalisme en Turquie" in Alain Dieckhoff and Riva Kastoryano, eds., Nationalismes en mutation en Méditerranée orientale (Paris: CNRS Éditions, 2002) 133.

Bozkurt, Gülnihâl. "Tanzimat and Law" in Tan₹imat'in 150. Yıldönümü Uluslararası Sempozyumu: Ankara: 31 Ekim - 3 Kasım 1989 (Ankara: Türk Tarih Kurumu Basımevi, 1994) 279.

---. Batı Hukukunun Türkiye'de Benimsenmesi: Osmanl Devleti’nden Türkiye Cumburiyeti’ne Resepsiyon Süreci (1839-1939) (Ankara: Türk Tarih Kurumu Basımevi, 1996).

Braude, Benjamin and Bernard Lewis, eds. Christians and Jews in the Ottoman Empire: The Functioning of a Plural Society, Two Vols. (New York: Holmes \& Meier, 1982).

Bridge, F. R. and Roger Bullen. The Great Powers and the European States System 1815-1914 (London: Longman Group Ltd., 1980).

Brierly, J. L. "Matters of Domestic Jurisdiction" 6 (1925) BYIL 8.

---. The Outlook for International Law (Oxford: Clarendon Press, 1944).

Brinton, Jasper Yeates. The Mixed Courts of Egypt (New Haven: Yale University Press, 1930).

Brown, Philip Marshall. Foreigners in Turkey; Their Juridical Status (Princeton: Princeton University Press, 1914).

---. "The Capitulations" 1 (1922-3) Foreign Affairs 71.

---. International Society: Its Nature and Interests (New York: Macmillan, 1923).

---. "From Sèvres to Lausanne" 18 (1924) AJIL 113.

Brownlie, Ian. "An Essay in the History of the Principle of Self-Determination" in C. H. Alexandrowicz, ed., Grotian Society Papers 1968: Studies in the History of the Law of Nations (The Hague: Nijhoff, 1970) 90.

Brunnée, Jutta and Stephen J. Toope. Legitimacy and Legality in International Law: An Interactional Account (Cambridge: Cambridge University Press, 2010).

Bryson, Thomas A. "Admiral Mark L. Bristol, an Open-Door Diplomat in Turkey" 5 (1974) International Journal of Middle East Studies 450. 
Bullard, Reader. Large and Loving Privileges: The Capitulations in the Middle East and North Africa (Glasgow: Jackson, Son, \& Co., 1960).

Burgwyn, H. James. Italian Foreign Policy in the Interwar Period 1918-1940 (Westport: Greenwood, 1997).

Butler, Geoffrey. "Sovereignty and the League of Nations" 1 (1920-1) BYIL 35.

Calderwood, H. B. The Protection of Minorities by the League of Nations (Geneva: Geneva Research Information Committee, 1931).

---. "Proposed Generalization of the Minorities Regime" 28 (1934) American Political Science Review 1088.

Caloyanni, M. A. “The Balkan Union, the Balkan Conferences, and the Balkan Pact” 18 (1932) TGS 97.

---. "The Balkan Union, the Balkan Conferences, and the Balkan Pact" 19 (1933) TGS 89.

Canefe, Nergis. "Modern Türk Toplumunda Zorunlu Göçlerin Mirası" in Nergis Canefe, Anavatandan Yavruvatana: Milliyetçilike, Bellek ve Aidiyet (İstanbul: İstanbul Bilgi Üniversitesi Yayınlar1, 2007) 77.

Carty, Anthony. " $19^{\text {th }}$ Century Textbooks and International Law", Ph.D. dissertation, University of Cambridge (1972).

Cassese, Antonio. Self-Determination of Peoples: A Legal Reappraisal (Cambridge: Cambridge University Press, 1995).

Castellan, Georges and Alexandre Jevakhoff. "Les Balkans et le Moyen-Orient" in François Boulet, ed., Les traités de paix 1919-1920 et l'Europe au XXème siècle: Versailles, Saint-Germain-enLaye, Neuilly-sur-Seine, Trianon, Sèvres (Paris: Les presses franciliennes, 2007) 339.

Castellino, Joshua. International Law and Self-Determination: The Interplay of the Politics of Territorial Possession with Formulations of Post-Colonial "National" Identity (The Hague: Nijhoff, 2000).

Caymaz, Birol. Türkiye'de Vatandaşlık: Resmî İdeoloji ve Yansimalar (İstanbul: İstanbul Bilgi Üniversitesi Yayınları, 2007).

Chandler, David. International Statebuilding: The Rise of Post-Liberal Governance (Abingdon: Routledge, 2010).

Chhangani, R. C. "Expulsion of Uganda Asians and International Law" 12 (1972) Indian Journal of International Law 400.

Chimni, B. S. "Third World Approaches to International Law: A Manifesto" in Antony Anghie et al., eds., The Third World and International Order: Law, Politics and Globalization (Leiden: Nijhoff, 2003) 47. 
Chirol, Valentine. "Our Imperial Interests in Nearer and Further Asia" in The Empire and the Century: A Series of Essays on Imperial Problems and Possibilities by Various Writers (London: John Murray, 1905) 728.

Citroen, H. A. European Emigration Overseas, Past and Future (The Hague: Nijhoff, 1951).

Claude Jr., Inis L. National Minorities: An International Problem (Cambridge, MA: Harvard University Press, 1955).

---. Swords into Plowshares: The Problems and Progress of International Organization, $3^{\text {rd }}$ Rev. Ed. (New York: Random House, 1964).

Clogg, Richard. A Concise History of Greece, $2^{\text {nd }}$ Ed. (Cambridge: Cambridge University Press, 1992).

---. "A Millet Within a Millet: The Karamanlides" in Dimitri Gondicas and Charles Issawi, eds., Ottoman Greeks in the Age of Nationalism: Politics, Economy, and Society in the Nineteenth Century (Princeton: Darwin Press, 1999) 115.

Conolly, Violet. Soviet Economic Policy in the East: Turkey, Persia, Afghanistan, Mongolia and Tana Tuva, Sin Kiang (London: Oxford University Press, 1933).

Corbett, P. E. "What is the League of Nations?” 5 (1924) BYIL 119.

Cowan, Jane K. “Who's Afraid of Violent Language? Honour, Sovereignty and Claims-Making in the League of Nations" 3 (2003) Anthropological Theory 271.

Crampton, R. J. Bulgaria (Oxford: Oxford University Press, 2007).

Curzon, George Nathaniel. Lord Curzon in India: Being a Selection from His Speeches as Viceroy and Governor-General of India 1898-1905 (London: Macmillan, 1906).

Cuthell, David. "A Kemalist Gambit: A View of the Political Negotiations in the Determination of the Turkish-Iraqi Border" in Reeva Spector Simon and Eleanor H. Tejirian, eds., The Creation of Iraq, 1914-1921 (New York: Columbia University Press, 2004) 80.

Çağaptay, Soner. "Population Resettlement and Immigration Policies of Interwar Turkey: A Study of Turkish Nationalism” 25 (2001) Turkish Studies Association Bulletin 1.

---. Islam, Secularism, and Nationalism in Modern Turkey: Who is a Turk? (New York: Routledge, 2006).

Çanl1, Mehmet. "Yunanistan'daki Türklerin Anadolu'ya Nakledilmesi I" 129 (1994) Tarih ve Toplum 54.

Dadrian, Vahakn N. "Genocide as a Problem of National and International Law: The World War I Armenian Case and Its Contemporary Legal Ramifications” 14 (1989) YJIL 221. ---. The History of the Armenian Genocide: Ethnic Conflict from the Balkans to Anatolia to the Caucasus, $3^{\text {rd }}$ Rev. Ed. (Providence: Berghahn Books, 1997). 
Dakin, Douglas. "The Importance of the Greek Army in Thrace during the Conference of Lausanne 1922-1923" in Greece and Great Britain during World War I: First Symposium Organized in Thessaloniki (December 15-17, 1983) by the Institute for Balkan Studies in Thessaloniki and King's College in London (Thessaloniki: Institute for Balkan Studies, 1985) 211.

Davison, Roderic H. Reform in the Ottoman Empire, 1856-1876 (Princeton: Princeton University Press, 1963).

---. "Ottoman Diplomacy at the Congress of Paris (1856) and the Question of Reforms" in VII. Türk Tarih Kongresi (Ankara: 25-29 Eylül 1970) - Kongreye Sunulan Bildiriler, Vol. II (Ankara: Türk Tarih Kurumu Basimevi, 1973) 580.

---. "Russian Skill and Turkish Imbecility': The Treaty of Kuchuk Kainardji Reconsidered” 35 (1976) Slavic Review 463.

---. "The Ottoman Empire and the Congress of Berlin" in Ralph Melville and Hans-Jürgen Schröder, eds., Der Berliner Kongress von 1878. Die Politik der Grossmächte und die Probleme der Modernisierung in Südosteuropa in der zweiten Hälfte des 19. Jahrbunderts (Wiesbaden: Steiner, 1982) 175.

Dawisha, Adeed. Arab Nationalism in the Twentieth Century: From Triumph to Despair (Princeton: Princeton University Press, 2003).

Dawn, C. Ernest. "The Rise of Arabism in Syria" in C. Ernest Dawn, From Ottomanism to Arabism: Essays on the Origins of Arab Nationalism (Urbana, IL: University of Illinois Press, 1973) 148.

---. "The Quality of Arab Nationalism" in Derek Hopwood, ed., Arab Nation, Arab Nationalism (Houndsmills: Macmillan, 2000) 41.

Deák, István. "How to Construct a Productive, Disciplined, Monoethnic Society: The Dilemma of East Central European Governments, 1914-1956" in Amir Weiner, ed., Landscaping the Human Garden: Twentieth-Century Population Management in a Comparative Framework (Stanford: Stanford University Press, 2003) 205.

Demirözü, Damla. "The Greek-Turkish Rapprochement of 1930 and the Repercussions of the Ankara Convention in Turkey" 19 (2008) Journal of Islamic Studies 309.

Deringil, Selim. The Well-Protected Domains: Ideology and the Legitimation of Power in the Ottoman Empire 1876-1909 (London: Tauris, 1998).

---. “Osmanlı'dan Türk'e: Türkiye'de Kimlik ve Sosyal Mühendislik” in Selim Deringil, Simgeden Millete: II. Abdülhamid'den Mustafa Kemal'e Devlet ve Millet (İstanbul: İletişim, 2007) 93.

Derluguian, Georgi M. Bourdieu's Secret Admirer in the Caucasus: A World-System Biography (Chicago: University of Chicago Press, 2005).

Devedji, Alexandre. L'échange obligatoire des minorités grecques et turques en vertu de la convention de Lausanne du 30 janvier 1923 (Paris: Imprimerie du Montparnasse et de Persan-Beaumont, 1929).

Dewey, John. "Secularizing a Theocracy" 40 (1924) The New Republic 69. 
---. "Foreign Schools in Turkey" 41 (1924) The New Republic 40.

---. "The Problem of Turkey" 41 (1924) The New Republic 162.

Dezalay, Yves. "Les courtiers de l'international: héritiers cosmopolites, mercenaires de l'impérialisme et missionnaires de l'universel' 151/152 (2004) Actes de la recherche en sciences sociales 5.

--- and Bryant G. Garth. Dealing in Virtue: International Commercial Arbitration and the Construction of a Transnational Legal Order (Chicago: University of Chicago Press, 1996).

--- and Bryant G. Garth. The Internationalization of Palace Wars: Lawyers, Economists, and the Contest to Transform Latin American States (Chicago: University of Chicago Press, 2002).

--- and Bryant G. Garth. Asian Legal Revivals: Lawyers in the Shadow of Empire (Chicago: University of Chicago Press, 2010).

de Azcárate, Pablo. League of Nations and National Minorities: An Experiment (Washington: Carnegie Endowment for International Peace, 1945).

de Jessen, Franz. "L’échange des populations turques et grecques” 5 (1923) RGDIP 510.

de Vattel, Emer. Le droit des gens. Ou Principes de la loi naturelle, appliqués à la conduite et aux affaires des Nations et des Souverains, Vol. I (Londres: n.p., 1758).

de Visscher, Charles. "Protection of Minorities" in Charles de Visscher, The Stabilization of Europe: Lectures on the Harris Foundation, 1924 (Chicago: University of Chicago Press, 1924) 27.

de Zayas, Alfred-Maurice. "International Law and Mass Population Transfers" 16 (1975) HILJ 207.

--- [as Alfred M. de Zayas]. Nemesis at Potsdam: The Anglo-Americans and the Expulsion of the Germans, $2^{\text {nd }}$ Rev. Ed. (London: Routledge \& Kegan Paul Ltd., 1979).

--- [as Alfred de Zayas]. "Collective Expulsions: Norms, Jurisprudence, Remedies" 16 (1997) Refugee Survey Quarterly 149.

---. A Terrible Revenge: The Ethnic Cleansing of the East European Germans (London: Palgrave Macmillan. 2006).

--- [as Alfred de Zayas]. "Forced Population Transfer" in Max Planck Encyclopedia of Public International Law, available online at: http://www.mpepil.com (last accessed 6 April 2011).

Dickinson, Edwin DeWitt. The Equality of States in International Law (Cambridge, MA: Harvard University Press, 1920).

Dobbins, James et al. The Beginner's Guide to Nation-Building (Santa Monica, CA: RAND Corporation, 2007).

Dowdall, H. C. “The Word 'State”' 39 (1923) LQR 98.

Dragostinova, Theodora. "Navigating Nationality in the Emigration of Minorities between Bulgaria and Greece, 1919-1941” 23 (2009) East European Politics and Societies 185. 
Drandar, A.-G. Les événements politiques en Bulgarie depuis 1876 jusqu'a nos jours (Bruxelles: Librairie européenne C. Muquardt, 1896).

Drew, Catriona J. "Population Transfer: The Untold Story of the International Law of SelfDetermination", Ph.D. dissertation, University of London (2005).

Dupuy, René-Jean. "La Révolution française et le droit international actuel” 214 (1989-II) RCADI 9.

Kurmuş, Orhan. "The 1838 Treaty of Commerce Re-examined" in Jean-Louis BacquéGrammont and Paul Dumont, eds., Économie et sociétés dans l'Empire ottoman, fin du XVIIIe - début du XXe siècle. Actes du colloque de Strasbourg, 1er - 5 juillet 1980 (Paris: Éditions du Centre national de la recherche scientifique, 1983) 411.

du Rausas, G. Pélissié. Le régime des capitulations dans l'Empire ottoman, Vol. I (Paris: Imprimerie C. Saillard, 1902).

Dündar, Fuat. İttihat ve Terakki’nin Müslümanlar İskân Politikası (1913-1918) (İstanbul: İletişim, 2001).

---. "The Settlement Policy of the Committee of Union and Progress 1913-1918" in HansLukas Kieser, ed., Turkey Beyond Nationalism: Towards Post-Nationalist Identities (New York: Tauris, 2006) 37.

---. Modern Türkiye'nin Şifresi: Ittihat ve Terakki'nin Etnisite Mühendisliği (1913-1918) (İstanbul: İletişim, 2008).

---. Crime of Numbers: The Role of Statistics in the Armenian Question (1878-1918) (New Brunswick, NJ: Transaction, 2010).

Ehrlich, Ludwik. "L'interprétation des traités" 24 (1928-IV) RCADI 5.

Eissenstat, Howard. "Turkic Immigrants / Turkish Nationalism: Opportunities and Limitations of a Nationalism in Exile" 25/26 (2003) Turkish Studies Association Bulletin 25.

Eldem, Edhem. "Ottoman Financial Integration with Europe: Foreign Loans, the Ottoman Bank and the Ottoman Public Debt" 13 (2005) European Review 431.

---. "Capitulations and Western Trade" in Suraiya N. Faroqhi, ed., The Cambridge History of Turkey, Vol. III (Cambridge: Cambridge University Press, 2006) 283.

Engelhardt, Ed. Le droit d'intervention et la Turquie: étude historique (Paris: A. Cotillon \& Cie, 1880). ---. La Turquie et le Tanzimat, ou Histoire des réformes dans l'Empire ottoman depuis 1826 jusqu'a nos jours (Paris: A. Cotillon et Cie, 1882).

Epstein, Mortimer. The Early History of the Levant Company (London: Routledge, 1908).

Erim, Nihat. Devletlerarası Hukuk ve Siyasi Tarih Metinleri, Vol. I (Ankara: Türk Tarih Kurumu Basimevi, 1953). 
Essad, Mahmoud. Du régime des capitulations ottomanes: leur caractère juridique d'après l'bistoire et les textes (Stamboul: S. A. de papeterie et d'imprimerie, Fratelli Haim, 1928).

Evans, Malcolm D. Religious Liberty and International Law in Europe (Cambridge: Cambridge University Press, 1997).

Evriviades, Marios L. "The Legal Dimensions of the Cyprus Conflict" 10 (1975) Texas International Law Journal 227.

Faber, G. S. The Predicted Downfall of the Turkish Power, the Preparation for the Return of the Ten Tribes (London: Thomas Bosworth, 1853).

Fachiri, Alexander P. The Permanent Court of International Justice: Its Constitution, Procedure and Work, $2^{\text {nd }}$ Ed. (London: Oxford University Press, 1932).

Fahmy, Khaled. All the Pasha's Men: Mehmed Ali, His Army and the Making of Modern Egypt (Cambridge: Cambridge University Press, 1997).

Fairman, Charles. "The Interpretation of Treaties” 20 (1934) TGS 123.

Feis, Herbert. Europe the World's Banker 1870-1914: An Account of European Foreign Investment and the Connection of World Finance with Diplomacy before the War (New York: Augustus M. Kelley, 1930).

Fieldhouse, D. K. Western Imperialism in the Middle East 1914-1958 (Oxford: Oxford University, 2006).

Findley, Carter V. "The Legacy of Tradition to Reform: Origins of the Ottoman Foreign Ministry" 1 (1970) International Journal of Middle East Studies 334.

---. "The Foundation of the Ottoman Foreign Ministry" 3 (1972) International Journal of Middle East Studies 388.

---. Bureaucratic Reform in the Ottoman Empire: The Sublime Porte, 1789-1922 (Princeton: Princeton University Press, 1980).

Fink, Carole. "The Minorities Question at the Paris Peace Conference: The Polish Minority Treaty, June 28, 1919" in Manfred F. Boemeke, Gerald D. Feldman, and Elisabeth Glaser, eds., The Treaty of Versailles: A Reassessment After 75 Years (Cambridge and Washington: Cambridge University Press / German Historical Institute, 1998) 249.

---. Defending the Rights of Others: The Great Powers, the Jews, and International Minority Protection, 1878 1938 (Cambridge: Cambridge University Press, 2004).

Fiore, Pasquale. Nouveau droit international public suivant les besoins de la civilisation moderne, tr. Charles Antoine, $2^{\text {nd }}$ Ed., Vol. I (Paris: A. Durand et Pedone-Lauriel, 1885).

Fisch, Jörg. "Internationalizing Civilization by Dissolving International Society: The Status of Non-European Territories in Nineteenth-Century International Law" in Martin H. Geyer and 
Johannes Paulmann, eds., The Mechanics of Internationalism: Culture, Society and Politics from the 1840s to the First World War (Oxford: Oxford University Press, 2001) 235.

---. "A Pamphlet War on Christian Missions in India 1807-1809" 19 (2005) Journal of Asian History 22.

Fischer-Tiné, Harald. "Global Civil Society and the Forces of Empire: The Salvation Army, British Imperialism, and the 'Prehistory' of NGOs (ca. 1880-1920)" in Sebastian Conrad and Dominic Sachsenmaier, eds., Competing Visions of World Order: Global Moments and Movements, 1880s-1930s (New York: Palgrave Macmillan, 2007) 29.

Fishel, Wesley R. The End of Extraterritoriality in China (Berkeley: University of California Press, 1952).

Fisher, John. "The Interdepartmental Committee on Eastern Unrest and British Responses to Bolshevik and Other Intrigues against the Empire during the 1920s" 34 (2000) Journal of Asian History 1.

Fleet, Kate. European and Islamic Trade in the Early Ottoman State: The Merchants of Genoa and Turkey (Cambridge: Cambridge University Press, 1999).

Fortna, Benjamin C. Imperial Classroom: Islam, the State, and Education in the Late Ottoman Empire (Oxford: Oxford University Press, 2002).

Foucault, Michel. The Birth of Biopolitics: Lectures at the Collège de France, 1978-79, ed. Michel Senellart and tr. Graham Burchell (Houndsmills: Palgrave Macmillan, 2008).

Fox, Gregory H. Humanitarian Occupation (Cambridge: Cambridge University Press, 2008).

Fragistas, Charalambos N. "Le droit musulman en Grèce" 4 (1954) Annales de la Faculté de droit d'Istanbul 129.

Frank, Matthew. Expelling the Germans: British Opinion and Post-1945 Population Transfer in Context (Oxford: Oxford University Press, 2007).

Fuad, Ali. La question des Détroits; ses origines, son évolution, sa solution à la Conférence de Lausanne (Paris: Montparnasse, 1928).

Fuccaro, Nelida. "Minorities and Ethnic Mobilisation: The Kurds in Northern Iraq and Syria" in Nadine Méouchy and Peter Sluglett, eds., The British and French Mandates in Comparative Perspectives (Leiden: Brill, 2004) 579.

Galiev, Sultan. "The Social Revolution and the East" [1919] in Alexandre A. Bennigsen and S. Enders Wimbush, eds., Muslim National Communism in the Soviet Union: A Revolutionary Strategy for the Colonial World (Chicago: University of Chicago Press, 1979) 131. 
Garibian, Sévane. "From the 1915 Allied Joint Declaration to the 1920 Treaty of Sèvres: Back to an International Criminal Law in Progress" 52 (2010) Armenian Review 86.

Geshkoff, Theodore I. Balkean Union: A Road to Peace in Southeastern Europe (New York: Columbia University Press, 1940).

Gilbert, Geoff. "Religio-nationalist Minorities and the Development of Minority Rights Law" 25 (1999) Review of International Studies 389.

Gingeras, Ryan. Sorrowful Shores: Violence, Ethnicity, and the End of the Ottoman Empire, 1912-1923 (Oxford: Oxford University Press, 2009).

Girard, André. Les minorités nationales ethniques et religieuses en Bulgarie (Paris: Marcel Giard, 1933).

Gittleman, Richard. "The African Charter on Human and Peoples' Rights - A Legal Analysis" 22 (1982) Virginia Journal of International Law 667.

Gladstone, William Ewart. The Berlin Treaty and the Anglo-Turkish Convention (London: Liberal Central Association, 1878).

Goebel, Christopher M. "Population Transfer, Humanitarian Law, and the Use of Ground Force in U.N. Peacemaking: Bosnia and Herzegovina in the Wake of Iraq" 25 (1992-3) NYUJILP 627.

Goffman, Daniel. "Negotiating with the Renaissance State: The Ottoman Empire and the New Diplomacy" in Virginia H. Aksan and Daniel Goffman, eds., The Early Modern Ottomans: Remapping the Empire (Cambridge: Cambridge University Press, 2007) 61.

Gong, Gerrit W. The Standard of "Civilization" in International Society (Oxford: Clarendon Press, 1984).

Goodwin-Gill, Guy S. International Law and the Movement of Persons between States (Oxford: Clarendon Press, 1978).

Gordon, Leland James. American Relations with Turkey 1830-1930: An Economic Interpretation (Philadelphia: University of Pennsylvania Press, 1932).

Gorman, Daniel. "Liberal Internationalism, the League of Nations Union, and the Mandates System” 40 (2005) Canadian Journal of History 449.

Göçek, Fatma Müge. Rise of the Bourgeoisie, Demise of Empire: Ottoman Westernization and Social Change (Oxford: Oxford University Press, 1996).

--- and M. Şükrü Hanioğlu. "Western Knowledge, Imperial Control, and the Use of Statistics in the Ottoman Empire" in Jayne L. Warner, ed., Cultural Horizons: A Festschrift in Honor of Talat S. Halman (Syracuse: Syracuse University Press / Yap1 Kredi Yayınları, 2001) 105. 
---. "The Decline of the Ottoman Empire and the Emergence of Greek, Armenian, Turkish, and Arab Nationalisms" in Fatma Müge Göçek, ed., Social Constructions of Nationalism in the Middle East (Albany: State University of New York Press, 2002) 15.

---. "The Politics of History and Memory: A Multidimensional Analysis of the Lausanne Peace Conference, 1922-1923" in Israel Gershoni, Hakan Erdem, and Ursula Woköck, eds., Histories of the Modern Middle East: New Directions (New York: Columbia University Press, 2002) 207.

Gökay, Bülent. A Clash of Empires: Turkey between Russian Bolshevism and British Imperialism, 1918 1923 (London: Tauris, 1997).

---. "The Kurdish Question in Turkey: Historical Roots, Domestic Concerns and International Law" in Nazila Ghanea and Alexandra Xanthaki, eds., Minorities, Peoples, and Self-Determination: Essays in Honour of Patrick. Thornberry (Leiden: Nijhoff, 2005) 315.

Grabill, Joseph L. Protestant Diplomacy and the Near East: Missionary Influence on American Policy, 1810-1927 (Minneapolis: University of Minnesota Press, 1971).

Grew, Joseph C. Turbulent Era: A Diplomatic Record of Forty Years, 1904-1945, ed. Walter Johnson, Vol. I (Boston: Houghton Mifflin Co., 1952).

Grewe, Wilhelm G. The Epochs of International Law, tr. and rev. Michael Byers (Berlin: Walter de Gruyter, 2000 [1984]).

Guilhot, Nicolas. The Democracy Makers: Human Rights and the Politics of Global Order (New York: Columbia University Press, 2005).

Gülalp, Haldun. "Capitalism and the Modern Nation-State: Rethinking the Creation of the Turkish Republic" 7 (1994) Journal of Historical Sociology 155.

Hamlin, Cyrus. Among the Turks (New York: American Tract Society, 1877).

Hanioğlu, M. Şükrü. A Brief History of the Late Ottoman Empire (Princeton: Princeton University Press, 2008).

Hannum, Hurst. "The Concept and Definition of Minorities" in Marc Weller, ed., Universal Minority Rights: A Commentary on the Jurisprudence of International Courts and Treaty Bodies (Oxford: Oxford University Press, 2007) 49.

Hansson, Michael. "L'Office international Nansen pour les réfugiés sous l'autorité de la Société des Nations" 1 (1938) Le Nord 181.

Harari, Maurice. "The Turco-Persian Boundary Question: A Case Study in the Politics of Boundary-Making in the Near and Middle East", Ph.D. dissertation, Columbia University (1958).

Harris, Paul William. Nothing but Christ: Rufus Anderson and the Ideology of Protestant Foreign Missions (New York: Oxford University Press, 1999). 
Hartmann, Hans W. "Les relations gréco-turques du traité de Lausanne au pacte d'Ankara, 1923-1933” 11 (1939) Les Balkeans 333.

Hathaway, James C. The Rights of Refugees under International Law (Cambridge: Cambridge University Press, 2005).

Hatschek, Julius. An Outline of International Law, tr. C. A. W. Manning (London: G. Bell and Sons Ltd., 1930).

Henckaerts, Jean-Marie. Mass Expulsion in Modern International Law and Practice (The Hague: Nijhoff, 1995).

Hershey, Amos S. "History of International Law since the Peace of Westphalia" 6 (1912) AJIL 30.

Heyking, Baron. “The International Protection of Minorities - The Achilles' Heel of the League of Nations” 13 (1927) TGS 31.

Hicks, Frederick Charles. The New World Order: International Organization, International Law, International Coöperation (Garden City, NY: Doubleday, Page \& Co., 1920).

Hieronymi, Otto. "The Nansen Passport: A Tool of Freedom of Movement and of Protection" 22 (2003) Refugee Survey Quarterly 36.

Higgins, Rosalyn. “The Role of National Courts in the International Legal Process” in Rosalyn Higgins, Problems and Process: International Law and How We Use It (Oxford: Clarendon, 1994) 205.

Hirschon, Renée. Heirs of the Greek Catastrophe: The Social Life of Asia Minor Refugees in Piraeus (Oxford: Clarendon Press, 1989).

---. "The Consequences of the Lausanne Convention: An Overview" in Renée Hirschon, ed., Crossing the Aegean: An Appraisal of the 1923 Compulsory Population Exchange between Greece and Turkey (New York: Berghahn, 2003) 13.

Hobsbawm, Eric. The Age of Revolution: 1789-1848 (London: Abacus, 1977 [1962]).

---. Nations and Nationalism since 1780: Programme, Myth, Reality, $2^{\text {nd }}$ Ed. (Cambridge: Cambridge University Press, 1992).

Hobson, J. A. Imperialism: A Study, $3^{\text {rd }}$ Rev. Ed. (London: George Allen \& Unwin Ltd., 1938 [1902]).

Holborn, Louise W. “The Legal Status of Political Refugees, 1920-1938” 32 (1938) AJIL 680.

Holland, Thomas Erskine. The European Concert in the Eastern Question (Oxford: Clarendon Press, 1885).

---. "The Execution of the Treaty of Berlin" [1882], in Thomas Erskine Holland, Studies in International Law (Oxford: Clarendon Press, 1898) 226. 
---. Lectures on International Law, ed. T. A. Walker and W. L. Walker (London: Sweet \& Maxwell Ltd., 1933).

Holquist, Peter. “'In Accord with State Interests and the People's Wishes': The Technocratic Ideology of Imperial Russia’s Resettlement Administration” 69 (2010) Slavic Review 151.

Hont, Istvan. 'The Permanent Crisis of a Divided Mankind: 'Nation-State' and 'Nationalism' in Historical Perspective" in Istvan Hont, Jealousy of Trade: International Competition and the NationState in Historical Perspective (Cambridge, MA: Harvard University Press, 2005) 447.

Horowitz, Richard S. "International Law and State Transformation in China, Siam, and the Ottoman Empire during the Nineteenth Century" 15 (2004) Journal of World History 445.

Howard, Harry Nicholas. The King-Crane Commission: An American Inquiry in the Middle East (Beirut: Khayats, 1963).

Hroch, Miroslav. "From National Movement to the Fully-formed Nation: The Nation-building Process in Europe" in Gopal Balakrishnan, ed., Mapping the Nation (London: Verso, 1996) 78.

Hudson, Manley O. "Law Reform in Turkey" 13 (1927) American Bar Association Journal 5. ---. Progress in International Organization (Stanford: Stanford University Press, 1932).

---. The World Court, 1921-1938: A Handbook of the Permanent Court of International Justice, $5^{\text {th }}$ Ed. (Boston: World Peace Foundation, 1938).

Huntford, Roland. Nansen: The Explorer as Hero (London: Duckworth, 1997).

---. Fridtjof Nansen and the Unmixing of Greeks and Turks in 1924 (Oslo: Norwegian Academy of Science and Letters, 1999).

Hurewitz, J. C. "Ottoman Diplomacy and the European State System" 15 (1961) Middle East Journal 141.

---. "The Europeanization of Ottoman Diplomacy: The Conversion from Unilateralism to Reciprocity in the Nineteenth Century" 25 (1961) Belleten 455.

--- ed. Diplomacy in the Near and Middle East: A Documentary Record: 1914-1956, Two Vols. (New York: Octagon, 1972).

Innes, Kathleen E. The Story of Nansen and the League of Nations (London: Friends Peace Committee, 1931).

Ivanoff, J. Les Bulgares devant le Congrès de la Paix. Documents historiques, ethnographiques et diplomatiques (Berne: Paul Haupt. Librairie académique, 1919).

İnalc1k, Halil. “Ottoman Methods of Conquest” 2 (1954) Studia Islamica 103.

---. "Imtiyāzāt" in B. Lewis et al., eds., The Encyclopaedia of Islam: New Edition, Vol. III (Leiden: Brill, 1986) 1179. 
İpek, Nedim. Rumeli'den Anadolu'ya Türk Göcleri (1877-1890) (Ankara: Türk Tarih Kurumu Basımevi, 1994).

---. Mübadele ve Samsun (Ankara: Türk Tarih Kurumu Basımevi, 2000).

İslamoğlu, Huri and Peter C. Perdue, eds. Shared Histories of Modernity: China, India and the Ottoman Empire (London: Routledge, 2009).

Janowsky, Oscar I. Nationalities and National Minorities (With Special Reference to East-Central Europe) (New York: Macmillan, 1945).

Jenks, C. Wilfred. The Prospects of International Adjudication (London: Stevens \& Sons Ltd., 1964).

Johnston, W. Ross. Sovereignty and Protection: A Study of British Jurisdictional Imperialism in the Late Nineteenth Century (Durham: Duke University Press, 1973).

Jones, Francis C. Extraterritoriality in Japan and the Diplomatic Relations Resulting in Its Abolition, 1853-1899 (New Haven: Yale University Press, 1931).

Junghann, Otto. The Origin and Solution of the Problems of National Minorities (Vienna: n. p., 1929).

Jwaideh, Wadie. The Kurdish National Movement: Its Origins and Development (Syracuse: Syracuse University Press, 2006).

Kabbara, Samy. Le régime des Détroits (Bosphore et Dardanelles) avant et depuis le traité de Lausanne (Lyon: Imprimerie BOSC Frères \& RIOU, 1929).

Kansu, Aykut. The Revolution of 1908 in Turkey (Leiden: Brill, 1997).

Karacan, Ali Naci. Lozan Konferansı ve İsmet Paşa (İstanbul: Maarif Matbaası, 1943).

Karakaya Stump, Ayfer. "Subjects of the Sultan, Disciples of the Shah: Formation and Transformation of the Kizilbash/Alevi Communities in Ottoman Anatolia", Ph.D. dissertation, Harvard University (2008).

Karakışla, Yavuz Selim. "The Emergence of the Ottoman Industrial Working Class, 1839-1923" in Donald Quataert and Erik Jan Zürcher, eds., Workers and the Working Class in the Ottoman Empire and the Turkish Republic 1839-1950 (London: Tauris, 1995) 19.

Karaömerlioğlu, M. Asim. "Helphand-Parvus and His Impact on Turkish Intellectual Life" 40 (2004) Middle Eastern Studies 145.

Karpat, Kemal H. Ottoman Population, 1830-1914: Demographic and Social Characteristics (Madison: University of Wisconsin Press, 1985).

---. The Politicization of Islam: Reconstructing Identity, State, Faith, and Community in the Late Ottoman State (Oxford: Oxford University Press, 2001). 
---. "The Ottoman Adoption of Statistics from the West in the $19^{\text {th }}$ Century" in Kemal H. Karpat, Studies on Ottoman Social and Political History: Selected Articles and Essays (Leiden: Brill, 2002) 132.

---. "Ottoman Relations with the Balkan Nations after 1683" in Kemal H. Karpat, Studies on Ottoman Social and Political History: Selected Articles and Essays: Selected Articles and Essays (Leiden: Brill, 2002) 385.

---. "The Muslim Minority in the Balkans" in Kemal H. Karpat, Studies on Turkish Politics and Society: Selected Articles and Essays (Leiden: Brill, 2004) 523.

---. "Ifta and Kara: The Ilmiye State and Modernism in Turkey, 1820-1960" in Colin Imber and Keiko Kiyotaki, eds., Frontiers of Ottoman Studies: State, Province, and the West, Vol. I (London: Tauris, 2005) 25.

Karvounarakis, Theo. "End of an Empire: Great Britain, Turkey and Greece from the Treaty of Sevres to the Treaty of Lausanne" 41 (2000) Balkan Studies 171.

Kasaba, Reşat. "Was There a Compradore Bourgeoisie in Mid-Nineteenth-Century Western Anatolia?" 11 (1988) Review 215.

---. The Ottoman Empire and the World Economy: The Nineteenth Century (Albany: State University of New York Press, 1988).

---. "Open-Door Treaties: China and the Ottoman Empire Compared" 7 (1992) New Perspectives on Turkey 71.

---. "A Time and a Place for the Nonstate: Social Change in the Ottoman Empire during the 'Long Nineteenth Century"' in Joel S. Migdal, Atul Kohli, and Vivienne Shue, eds., State Power and Social Forces: Domination and Transformation in the Third World (Cambridge: Cambridge University Press, 1994) 207.

---. A Moveable Empire: Ottoman Nomads, Migrants, and Refugees (Seattle: University of Washington Press, 2009).

Katz, Yossi. "Transfer of Population as a Solution to International Disputes: Population Exchanges between Greece and Turkey as a Model for Plans to Solve the Jewish-Arab Dispute in Palestine during the 1930s" 11 (1992) Political Geography 55.

Kaufmann, Chaim D. "When All Else Fails: Ethnic Population Transfers and Partitions in the Twentieth Century” 23 (1998) International Security 120.

Kaya, İbrahim. Social Theory and Later Modernities: The Turkish Experience (Liverpool: Liverpool University Press, 2004).

Kayal1, Hasan. Arabs and Young Turks: Ottomanism, Arabism, and Islamism in the Ottoman Empire, 1908-1918 (Berkeley: University of California Press, 1997).

Kazgan, Gülten. "Millî Türk Devletinin Kuruluşu ve Göçler” 30 (1970-1) Istanbul Üniversitesi İktisat Fakültesi Mecmuasi 311.

Keene, Edward. Beyond the Anarchical Society: Grotius, Colonialism and Order in World Politics (Cambridge: Cambridge University Press, 2002). 
Keeton, G. W. The Development of Extraterritoriality in China, Two Vols. (New York: Howard Fertig, 1969).

Keith, Berriedale. "The League of Nations and Mosul" 8 (1926) Journal of Comparative Legislation and International Law 38.

Keitner, Chimène. The Paradoxes of Nationalism: The French Revolution and Its Meaning for Contemporary Nation Building (Albany: State University of New York Press, 2007).

Kelsen, Hans. Legal Technique in International Law: A Textual Critique of the League Covenant (Geneva: Geneva Research Centre, 1939).

Kemal, Mustafa. "Gazi Mustafa Kemal Paşa Hazretlerinin İlk Türkiye İktisat Kongresindeki İftitahī Nutukları” in A. Afetinan, ed., İmir İktisat Kongresi (17 Subat - 4 Mart 1923) (Ankara: Türk Tarih Kurumu Basımevi, 1989) 57.

---. "Ankara Hukuk Fakültesinin Açllssında (5.XI.1925)", in Taha Parla, ed., Türkiye'de Siyasal Kültürün Resmî Kaynaklar, Vol. III (İstanbul: İletişim, 1992) 292.

Kennedy, C. M. The Influence of Christianity upon International Law (Cambridge: Macmillan, 1856).

Kennedy, David. “The Move to Institutions” 8 (1987) Cardozo Law Review 841.

Keyder, Çağlar. The Definition of a Peripheral Economy: Turkey 1923-1929 (Cambridge: Cambridge University Press / Éditions de la maison des sciences de l'homme, 1981).

---. "The Ottoman Empire" in Karen Barkey and Mark von Hagen, eds., After Empire: Multiethnic Societies and Nation-Building - The Soviet Union and the Russian, Ottoman, and Habsburg Empires (Boulder: Westview Press, 1997) 30.

---. "Bir Türk Milliyetçilik Tarihi ve Coğrafyası" in Çağlar Keyder, Memâlik-i Osmaniye'den Avrupa Birliğine (İstanbul: İletişim, 2003) 73.

---. "The Consequences of the Exchange of Populations for Turkey" in Renée Hirschon, ed., Crossing the Aegean: An Appraisal of the 1923 Compulsory Population Exchange between Greece and Turkey (New York: Berghahn, 2003) 39.

Kévonian, Dzovinar. Réfugiés et diplomatie humanitaire. Les acteurs européens et la scène proche-orientale pendant l'entre-deux-guerres (Paris: Publications de la Sorbonne, 2004).

Khadduri, Majid. "The Alexandretta Dispute” 39 (1945) AJIL 406.

Khalidi, Rashid. "Ottomanism and Arabism in Syria Before 1914: A Reassessment" in Rashid Khalidi et al., ed., The Origins of Arab Nationalism (New York: Columbia University Press, 1991) 50.

Khan, Yasmin. The Great Partition: The Making of India and Pakistan (New Haven: Yale University Press, 2007). 
Kieser, Hans-Lukas. Iskalanmış Barış: Doğu Vilayetleri'nde Misyonerlik, Etnik Kimlik ve Devlet 18391938, tr. Atilla Dirim (İstanbul: İletişim, 2005).

---. Türklï̈ge İbtida: 1870-1939 Isviçre'sinde Yeni Türkiye'nin Öncüleri, tr. Atilla Dirim (İstanbul: İletişim, 2008).

---. Nearest East: American Millennialism and Mission to the Middle East (Philadelphia: Temple University Press, 2010).

Kingsbury, Benedict. "Sovereignty and Inequality" 9 (1998) EJIL 599.

Kirişci, Kemal. "Migration and Turkey: The Dynamics of State, Society and Politics" in Reşat Kasaba, ed., The Cambridge History of Turkey, Vol. IV (Cambridge: Cambridge University Press, 2006) 175.

Kiskira, Constantia. "Evangelising' the Orient; New England Womanhood in the Ottoman Empire, 1830-1930” 16 (1998) Archivum Ottomanicum 279.

Kiyotaki, Keiko. "The Implementation of the Administrative Law of 1864 in the Province of Baghdad" in Markus Köhbach, Gisela Prochházka-eisl, and Claudia Römer, eds., Acta Viennensia Ottomanica. Akten des 13. CIEPO - Symposiums vom 21. bis 25. September 1998 in Wien (Wien: Selbstverlag des Instituts für Orientalistik, 1999) 215.

Knop, Karen. Diversity and Self-Determination in International Law (Cambridge: Cambridge University Press, 2002).

Kocabaşoğlu, Uygur. Anadolu'daki Amerika: Kendi Belgeleriyle 19. Yü̈yllda Osmanlı Imparatorlü̆u'ndaki Amerikan Misyoner Okulları (Ankara: İmge, 2000).

Koçu, Reşad Ekrem. Osmanl Muahedeleri, Kapitülasyonlar, 1300-1920, ve Lozan Muahedesi, 24 Temmuг 1923 (İstanbul: Muallim Ahmet Halit Kitaphanesi, 1934).

Koese, Yavuz. "Nestlé in the Ottoman Empire: Global Marketing with Local Flavour 18701927" 9 (2008) Enterprise and Society 724.

Kołodziejczyk, Dariusz. Ottoman-Polish Diplomatic Relations $\left(15^{\text {th }}-18^{\text {th }}\right.$ Century): An Annotated Edition of 'Ahdnames and Other Documents (Leiden: Brill, 2000).

Kontogiorgi, Elisabeth. "Economic Consequences following Refugee Settlement in Greek Macedonia, 1923-1932" in Renée Hirschon, ed., Crossing the Aegean: An Appraisal of the 1923 Compulsory Population Exchange between Greece and Turkey (New York: Berghahn, 2003) 63.

Kooijmans, P. H. The Doctrine of the Legal Equality of States: An Inquiry into the Foundations of International Law (Leyden: A. W. Sythoff, 1964).

Korhonen, Outi. “The 'State-Building Enterprise': Legal Doctrine, Progress Narratives and Managerial Governance" in Brett Bowden, Hilary Charlesworth, and Jeremy Farrall, eds., The 
Role of International Law in Rebuilding Societies after Conflict: Great Expectations (Cambridge: Cambridge University Press, 2009) 15.

Koskenniemi, Martti. "National Self-Determination Today: Problems of Legal Theory and Practice" 43 (1994) ICLQ 241.

---. The Gentle Civilizer of Nations: The Rise and Fall of International Law 1870-1960 (Cambridge: Cambridge University Press, 2001).

---. "Into Positivism: Georg Friedrich von Martens (1756-1821) and Modern International Law" 15 (2008) Constellations 189.

---. "The Legacy of the Nineteenth Century" in David Armstrong, ed., Routledge Handbook of International Law (London: Routledge, 2009) 141.

Koufa, Kalliopi K. and Constantinos Svolopoulos. "The Compulsory Exchange of Populations Between Greece and Turkey: The Settlement of Minority Questions at the Conference of Lausanne, 1923, and Its Impact on Greek-Turkish Relations" in Paul Smith, Kalliopi Koufa, and Arnold Suppan, eds., Ethnic Groups in International Relations (New York: New York University Press, 1991) 275.

Köksal, Yonca. "Minority Policies in Bulgaria and Turkey: The Struggle to Define a Nation" 6 (2006) Southeast European and Black Sea Studies 501.

---. "Rethinking Nationalism: State Projects and Community Networks in $19^{\text {th }}$-Century Ottoman Empire" 51 (2008) American Behavioral Scientist 1498.

Köver, Gustave. Histoire d'une trabison: le calvaire des minorités nationales et la Société des Nations (Genève: Editions du Bureau central des minorités, 1939).

---. L'erreur initiale de la Société des Nations: Documents pour server à l'histoire de la question minoritaire (Genève: Édition du Bureau central des minorités, 1940).

Kuneralp, Sinan. "Ottoman Diplomacy and the Controversy over the Interpretation of Article 4 of the Turco-American Treaty of 1830" 31 (2000) Turkish Yearbook of International Relations 7.

Kunz, Joseph L. "L’option de nationalité" 31 (1930-I) RCADI 107.

--- [as Josef L. Kunz]. "The Law of Nations, Static and Dynamic" 27 (1933) AJIL 630.

--- [as Josef L. Kunz]. "The Future of the International Law for the Protection of National Minorities” 39 (1945) AJIL 89.

Kuyucu, Ali Tuna. "Ethno-religious 'Unmixing' of 'Turkey': 6-7 September Riots as a Case in Turkish Nationalism” 11 (2005) Nations and Nationalism 361.

Ladas, Stephen P. The Exchange of Minorities: Bulgaria, Greece and Turkey (New York: Macmillan, 1932).

Lane, Winthrop D. "Why Greeks and Turks Oppose Being 'Exchanged”' 18 (1923) New York Times Current History 86.

Laski, Harold J. Studies in the Problem of Sovereignty (New Haven: Yale University Press, 1917). 
Lauren, Paul Gordon. "Human Rights in History: Diplomacy and Racial Equality at the Paris Peace Conference” 2 (1978) Diplomatic History 257.

Lauterpacht, Hersch. "The Pact of Paris and the Budapest Articles of Interpretation” 20 (1934) TGS 178.

---. The Development of International Law by the International Court, Rev. Ed. (London: Stevens \& Sons Ltd., 1958).

---. "International Law and Colonial Questions, 1870-1914" in International Law, Being the Collected Papers of Hersch Lauterpacht, Vol. II, ed. Elihu Lauterpacht (Cambridge: Cambridge University Press, 1975) 95.

Laven, David and Lucy Riall. "Restoration Government and the Legacy of Napoleon" in David Laven and Lucy Riall, eds., Napoleon's Legacy: Problems of Government in Restoration Europe (Oxford: Berg, 2000) 1.

Lawrence, T. J. "The Primacy of the Great Powers" in T. J. Lawrence, Essays on Some Disputed Questions in Modern International Law, $2^{\text {nd }}$ Ed. (Cambridge: Deighton, Bell \& Co., 1885) 208.

---. The Principles of International Law, $4^{\text {th }}$ Ed. (Boston: D. C. Heath \& Co., 1910).

Leach, Henry Goddard. "Fridtjof Nansen” 14 (1948) University of Kansas City Review 167.

Lebeau, Charles-Hippolyte. Essai sur la justice en Turquie (Paris: Marcel Rivière et Cie., 1924).

Lenin, Vladimir Ilyich. "Imperialism, the Highest Stage of Capitalism" [1917] in Henry M. Christman, ed., Essential Works of Lenin: "What Is to Be Done?" and Other Writings (Mineola, NY: Dover, 1987) 177.

Leontiades, Leonidas. "Der griechisch-türkische Bevölkerungsaustausch" 5 (1935) ZaöRV 546.

Lerner, Natan. "The Evolution of Minority Rights in International Law" in Catherine Brölman, René Lefeber, and Marjoleine Zieck, eds., Peoples and Minorities in International Law (Dordrecht: Nijhoff, 1993) 77.

Levene, Mark. "Creating a Modern 'Zone of Genocide': The Impact of Nation- and StateFormation on Eastern Anatolia, 1878-1923" 12 (1998) Holocaust and Genocide Studies 393.

---. "The Limits of Tolerance: Nation-State Building and What it Means for Minority Groups" 34 (2000) Patterns of Prejudice 19.

Lewis, Bernard. The Emergence of Modern Turkey, $3^{\text {rd }}$ Ed. (Oxford: Oxford University Press, 2002).

Liebich, Andre. "Minority as Inferiority: Minority Rights in Historical Perspective" 34 (2008) Review of International Studies 243.

Lieven, Dominic. "Dilemmas of Empire 1850-1918. Power, Territory, Identity" 34 (1999) Journal of Contemporary History 163. 
Lindley, Mark Frank. The Acquisition and Government of Backward Territory in International Law, Being a Treatise on the Law and Practice relating to Colonial Expansion (London: Longmans, Green, and Co., 1926).

Lipsett, H. C. Lord Curzon in India 1898-1903 (London: Everett \& Co., 1903).

Liu, Shih Shun. Extraterritoriality: Its Rise and Its Decline (New York: Columbia University Press, 1925).

Loewenfeld, Erwin. "The Protection of Private Property under the Minorities Protection Treaties" 16 (1930) TGS 41.

Loizos, Peter. "Ottoman Half-Lives: Long-Term Perspectives on Particular Forced Migrations" 12 (1999) Journal of Refugee Studies 237.

Lorimer, James. The Institutes of the Law of Nations: A Treatise of the Jural Relations of Separate Political Communities, Vol. I (Edinburgh: W. Blackwood \& Sons, 1883).

---. "Of the Denationalisation of Constantinople, and Its Devotion to International Interests" [1876] in James Lorimer, Studies National and International, Being Occasional Lectures Delivered in the University of Edinburgh 1864-1889 (Edinburgh: William Green \& Sons, 1890) 121.

---. "Does the Corân Supply an Ethical Basis on Which a Political Superstructure Can Be Raised?" [1877-8] in James Lorimer, Studies National and International, Being Occasional Lectures Delivered in the University of Edinburgh 1864-1889 (Edinburgh: William Green \& Sons, 1890) 132.

Loughlin, Martin. The Idea of Public Law (Oxford: Oxford University Press, 2003).

Lutfi, K. Omer. Die völkerrechtliche Stellung Bulgariens und Ostrumeliens (Erlangen: E. Th. Jacob, 1903).

Lybyer, Albert H. “The Balkan Situation” 10 (1920) Journal of International Relations 404.

Macartney, C. A. National States and National Minorities (Oxford: Oxford University Press, 1934).

Machiavelli, Niccolò. The Prince, ed. Quentin Skinner and Russell Price (Cambridge: Cambridge University Press, 1988 [1532]).

MacMillan, Margaret. Paris 1919: Six Months That Changed the World (New York: Random House, 2003).

Mair, L. P. The Protection of Minorities: The Working and Scope of the Minorities Treaties under the League of Nations (London: Christophers, 1928).

Makdisi, Ussama. "Ottoman Orientalism” 107 (2002) American Historical Review 768.

---. Artillery of Heaven: American Missionaries and the Failed Conversion of the Middle East (Ithaca: Cornell University Press, 2008). 
Mandelstam, André. “La protection des minorités” 1 (1923-I) RCADI 363.

---. La Société des Nations et les puissances devant le problème arménien (Paris: Pédone, 1926).

Manela, Erez. The Wilsonian Moment: Self-Determination and the International Origins of Anticolonial Nationalism (Oxford: Oxford University Press, 2007).

Mann, Michael. The Dark Side of Democracy: Explaining Ethnic Cleansing (Cambridge: Cambridge University Press, 2005).

Mansergh, Nicholas. “The Partition of India in Retrospect” 21 (1965-6) International Journal 1.

Mardin, Şerif. The Genesis of Young Ottoman Thought: A Study in the Modernization of Turkish Political Ideas (Princeton: Princeton University Press, 1962).

---. “Center-Periphery Relations: A Key to Turkish Politics?” 102 (1973) Daedalus 169.

Marrin, Albert. The Last Crusade: The Church of England in the First World War (Durham: Duke University Press, 1974).

Marriott, J. A. R. The Eastern Question: An Historical Study in European Diplomacy (Oxford: Clarendon Press, 1917).

Marrus, Michael R. The Unwanted: European Refugees from the First World War through the Cold War (Philadelphia: Temple University Press, 2002).

Marsot, Afaf Lutfi al-Sayyid. Egypt in the Reign of Mubammad Ali (Cambridge: Cambridge University Press, 1984).

Martens, Friedrich. Das Consularwesen und die Consularjurisdiction im Orient, tr. H. Skerst (Berlin: Weidmannsche Buchhandlung, 1874).

Marx, Karl. Capital: A Critique of Political Economy, Volume One, tr. Ben Fowkes (London: Penguin Books, 1990 [1867]).

--- and Friedrich Engels. "For Poland" [1875], tr. Paul Jackson, in The First International and After: Political Writings, Vol. III (London: Penguin / New Left Review, 1974) 388.

Masters, Bruce. "The Sultan's Entrepreneurs: The Avrupa Tüccaris and the Hayriye Tüccaris in Syria" 24 (1992) International Journal of Middle East Studies 579.

---. Christians and Jews in the Ottoman Arab World: The Roots of Sectarianism (Cambridge: Cambridge University Press, 2001).

Matas, David. "Prosecuting Crimes against Humanity: The Lessons of World War I" 13 (198990) Fordham International Law Journal 86.

Matuz, Joseph. “À propos de la validité des capitulations de 1536 entre l'Empire ottoman et la France” 24 (1992) Turcica 183. 
Mayer, Arno J. Wilson vs. Lenin: Political Origins of the New Diplomacy, 1917-1918 (New Haven: Yale University Press, 1959).

Mazard, Jean-Albert. Le régime des capitulations en Turquie pendant la guerre de 1914 (Alger: Imprimerie Jean Gaudet, 1923).

Mazower, Mark. The Balkans: A Short History (New York: The Modern Library, 2002).

---. No Enchanted Palace: The End of Empire and the Ideological Origins of the United Nations (Princeton: Princeton University Press, 2009).

Mazzini, Giuseppe. "The European Question: Foreign Intervention and National SelfDetermination" [1847] in Stefano Recchia and Nadia Urbinati, eds., A Cosmopolitanism of Nations: Giuseppe Mazzini's Writings on Democracy, Nation Building, and International Relations (Princeton: Princeton University Press, 2009) 193.

---. "On Nonintervention" [1851] in Stefano Recchia and Nadia Urbinati, eds., $A$ Cosmopolitanism of Nations: Giuseppe Mazzini's Writings on Democracy, Nation Building, and International Relations (Princeton: Princeton University Press, 2009) 213.

Mälksoo, Lauri. "The History of International Legal Theory in Russia: A Civilizational Dialogue with Europe” 19 (2008) EJIL 211.

McCarthy, Justin. Death and Exile: The Ethnic Cleansing of Ottoman Muslims, 1821-1922 (Princeton: Darwin Press, 1995).

McDowall, David. A Modern History of the Kurds (London: Tauris, 1997).

McKeown, Adam. “Global Migration, 1846-1940” 15 (2004) Journal of World History 155.

McNair, Arnold D. "Equality in International Law” 26 (1927) Michigan Law Review 131.

Medlicott, William Norton. The Congress of Berlin and After: A Diplomatic History of the Near Eastern Settlement 1878-1880 (London: Methuen \& Co., 1938).

Meijknecht, Anna. Towards International Personality: The Position of Minorities and Indigenous Peoples in International Law (Antwerp: Intersentia, 2001).

Meindersma, Christa. "Population Exchanges: International Law and State Practice - Part 1" 9 (1997) International Journal of Refugee Law 335.

---. "Populations Exchanges: International Law and State Practice - Part 2" 9 (1997) International Journal of Refugee Law 613.

Meray, Seha L. Devletler Hukukuna Giriş, Vol. I (Ankara: Ajans-Türk Matbaas1, 1959).

Merriam, C. E. History of the Theory of Sovereignty since Roussean (New York: Columbia University Press, 1900). 
Miller, David Hunter. My Diary at the Conference of Paris, with Documents, Vol. IV (New York: Appeal Printing, 1924).

---. The Drafting of the Covenant, Two Vols. (New York and London: G. P. Putnam's Sons, 1928).

Millman, Richard. Britain and the Eastern Question 1875-1878 (Oxford: Clarendon Press, 1979).

Mirkine-Guetzévitch, Boris. "L'influence de la Révolution française sur le développement du droit international dans l'Europe orientale” 22 (1928-II) RCADI 295.

Mitchell, Timothy. “The Work of Economics: How a Discipline Makes Its World” 46 (2005) European Journal of Sociology 297.

Molony, William O'Sullivan. Nationality and the Peace Treaties (London: Allen and Unwin, 1934).

Morgenthau, Henry. I W as Sent to Athens (Garden City, NY: Doubleday, Doran \& Co., 1929).

Mourelos, Yannis G. "The 1914 Persecutions and the First Attempt at an Exchange of Minorities between Greece and Turkey" 26 (1985) Balkan Studies 389.

Moyn, Samuel. The Last Utopia: Human Rights in History (Cambridge, MA: Harvard University Press, 2010).

Murphey, Rhoads. Exploring Ottoman Sovereignty: Tradition, Image and Practice in the Ottoman Imperial Household, 1400-1800 (London: Continuum, 2008).

Musgrave, Thomas D. Self-Determination and National Minorities (Oxford: Oxford University Press, 1997).

Mutua, Makau. "What is TWAIL?” 94 (2000) ASIL Pd. 31.

Myles, Eric. “'Humanity', 'Civilization' and the 'International Community' in the Late Imperial Russian Mirror: Three Ideas “Topical for our Days”” 4 (2002) JHIL 310.

Naff, Thomas. "The Ottoman Empire and the European States System” in Hedley Bull and Adam Watson, eds., The Expansion of International Society (Oxford: Clarendon Press, 1984) 143.

Naimark, Norman M. Fires of Hatred: Ethnic Cleansing in Twentieth-Century Europe (Cambridge, MA: Harvard University Press, 2001).

Nakracas, Georgios. Anadolu ve Rum Gögmenlerin Kökeni: 1922 Emperyalist Yunan Politikasi ve Anadolu Felaketi, tr. İbram Onsunoğlu (İstanbul: Belge, 2000).

Nansen, Fridtjof. Vers le Pôle, tr. Charles Rabot (Paris: Ernest Flammarion, 1897).

--- ed. The Norwegian North Polar Expedition, 1893-1896: Scientific Results, Six Vols. (Christiania: Jacob Dybwad, 1900-5).

---. Norway and the Union with Sweden (London: Macmillan, 1905). 
---. In Northern Mists: Arctic Exploration in Early Times, Two Vols., tr. Arthur G. Chater (London: William Heinemann, 1911).

---. Through Siberia, the Land of the Future, tr. Arthur G. Chater (London: William Heinemann, 1914).

---. Armenia and the Near East (London: George Allen \& Unwin, 1928).

---. "The Suffering People of Europe" in Fredrick W. Haberman, ed., Nobel Lectures: Peace, 1901 1925, Vol. I (Amsterdam: Elsevier, 1972) 361.

Necatigil, Zaim M. The Cyprus Question and the Turkish Position in International Law, $2^{\text {nd }}$. Rev. Ed. (Oxford: Oxford University Press, 1993).

Neff, Stephen C. "Conflict Termination and Peace-Making in the Law of Nations: A Historical Perspective" in Carsten Stahn and Jann K. Kleffner, eds., Jus Post Bellum: Towards a Law of Transition from Conflict to Peace (The Hague: T. M. C. Asser, 2008) 77.

Nicolson, Harold. Curzon, The Last Phase, 1919-1925: A Study in Postwar Diplomacy (London: Constable \& Co., 1934).

---. The Congress of Vienna: A Study in Allied Unity: 1812-1822 (New York: Grove, 1946).

Noel-Baker, Philip. The Financial Reconstruction of Europe (Geneva: League of Nations, 1922).

---. The League of Nations at Work (London: Nisbet \& Co., 1926).

---. "Le statut juridique actuel des dominions britanniques dans le domaine du droit international" 19 (1927-IV) RCADI 248.

--- [as Philip Noel Baker]. "Nansen and Norway" in J. Howard Whitehouse, ed., Nansen: A Book of Homage (London: Hodder and Stoughton, 1930) 83.

Nur, Rıza. Lozan Hatıralar (İstanbul: Boğaziçi Yayınları, 1999).

Olson, Robert. The Emergence of Kurdish Nationalism and the Sheikh Said Rebellion, 1880-1925 (Austin: University of Texas Press, 1989).

"On Freedom of Commerce in the Ottoman Empire" Moniteur ottoman [n.d.], reproduced in David Ross, ed., Opinions of the European Press on the Eastern Question. Translated and Extracted from Turkish, German, French, and English Papers and Reviews (London: James Ridgway \& Sons, 1836) 1.

Onuma, Yasuaki. "When was the Law of International Society Born? - An Inquiry of the History of International Law from an Intercivilizational Perspective" 2 (2000) JHIL 1.

---. A Transcivilizational Perspective on International Law (Leiden: Nijhoff, 2010).

Oppenheim, Lassa. International Law: A Treatise, Vol. I, ed. Ronald F. Roxburgh, $2^{\text {nd }}$ Ed. (London: Longmans, Green, \& Co., 1912).

---. International Law: A Treatise, Vol. I, ed. Ronald F. Roxburgh, $3^{\text {rd }}$ Ed. (London: Longmans, Green, \& Co., 1920). 
Oran, Baskin. "The Story of Those Who Stayed: Lessons from Articles 1 and 2 of the 1923 Convention" in Renée Hirschon, ed., Crossing the Aegean: An Appraisal of the 1923 Compulsory Population Exchange between Greece and Turkey (New York: Berghahn, 2003) 97.

---. Türkiye'de Ažnliklar: Kavramlar, Teori, Lozan, İc Mevzuat, İctibat, Uygulama (İstanbul: İletişim, 2004).

---. "Lausanne Barış Antlaşması" in Baskın Oran, ed., Türk Dış Politikası: Kurtuluş Savaşından Bugüne Olgular, Belgeler, Yorumlar (İstanbul: İletişim, 2001) 215.

---. "The Minority Concept and Rights in Turkey: The Lausanne Peace Treaty and Current Issues" in Zehra F. Kabasakal Arat, ed., Human Rights in Turkey (Philadelphia: University of Pennsylvania Press, 2007) 35.

Orford, Anne. International Authority and the Responsibility to Protect (Cambridge: Cambridge University Press, 2011).

Ortayl, İlber. İmparatorluğun En Uzun Yüzyılı (İstanbul: İletişim, 1999).

Ostrorog, Léon. The Angora Reform: Three Lectures Delivered at the Centenary Celebrations of University College on June 27, 28 \& 29, 1927 (London: University of London Press, 1927).

Owen, Roger. The Middle East in the World Economy 1800-1914 (London: Methuen, 1981).

Örücü, Esin. “The Impact of European Law on the Ottoman Empire and Turkey” in W. J. Mommsen and J. A. de Moor, eds., European Expansion and Law: The Encounter of European and Indigenous Law in 19th- and 20th-Century Africa and Asia (Oxford: Berg, 1992) 39.

Özbek, Nadir. Osmanl Imparatorluğu'nda Sosyal Devlet: Siyaset, İktidar ve Messruiyet 1876-1914 (İstanbul: İletişim, 2002).

Özcan, Azmi. Pan-Islamism: Indian Muslims, the Ottomans and Britain (1877-1924) (Leiden: Brill, 1997).

Özdemir, Renk. "Borders of Belonging in the 'Exchanged' Generations of Karamanlis" in Ahmet İçduygu and Kemal Kirişci, eds., Land of Diverse Migrations: Challenges of Emigration and Immigration in Turkey (İstanbul: İstanbul Bilgi University Press, 2009) 29.

Özgiray, Ahmet. "Turco-French Relations and the Syrian Border Question (1924-1930)" in Daniel Panzac, ed., Histoire économique et sociale de l'Empire ottoman et de la Turquie (1326-1960). Actes du sixième congres international tenu à Aix-en-Provence du 1er au 4 juillet 1992 (Leuven: Peeters, 1995) 671.

Özsu, Umut. “Agency, Universality, and the Politics of International Legal History” 51 (2010) HILJ Online 58.

Pallieri, Giorgio Balladore. "Les transferts internationaux de populations" 44 (1952-II) AIDI 138. 
Pallis, A. A. "The Exchange of Populations in the Balkans" 97 (1925) The Nineteenth Century and After 376.

---. "The Population of Turkey in 1935” 91 (1938) Geographical Journal 439.

Pamuk, Şevket. The Ottoman Empire and European Capitalism, 1820-1913: Trade, Investment and Production (Cambridge: Cambridge University Press, 1987).

---. "The Ottoman Economy in World War I" in Stephen Broadberry and Mark Harrison, eds., The Economics of World War I (Cambridge: Cambridge University Press, 2005) 112.

---. "Economic Change in Twentieth-Century Turkey: Is the Glass More Than Half Full?" in Reşat Kasaba, ed., The Cambridge History of Turkey, Vol. IV (Cambridge: Cambridge University Press, 2006) 266.

Panaite, Viorel. The Ottoman Law of War and Peace: The Ottoman Empire and Tribute Payers (Boulder: East European Monographs / New York: Columbia University Press, 2000).

Pandolfi, Mariella. "From Paradox to Paradigm: The Permanent State of Emergency in the Balkans" in Didier Fassin and Mariella Pandolfi, eds., Contemporary States of Emergency: The Politics of Military and Humanitarian Interventions (New York: Zone Books, 2010) 153.

Paprocki, Stanislaw J. La Pologne et le problème des minorities. Recueil d'informations (Varsovie: Institut pour l'etude des questions minoritaires, 1935).

Parla, Taha and Andrew Davison. Corporatist Ideology in Kemalist Turkey: Progress or Order? (Syracuse: Syracuse University Press, 2004).

Paz, Moria. "A Non-Territorial Ethnic Network and the Making of Human Rights Law: The Case of the Alliance Israélite Universelle" 4 (2010) Interdisciplinary Journal of Human Rights Law 1.

Pedersen, Susan. "Back to the League of Nations" 112 (2007) American Historical Review 1091.

---. "Getting Out of Iraq - in 1932: The League of Nations and the Road to Normative Statehood” 115 (2010) American Historical Review 975.

Pekin, Müfide, ed. Yeniden Kurulan Yaşamlar: 1923 Türk-Yunan Zorunlu Nüfus Mübadelesi (İstanbul: İstanbul Bilgi Üniversitesi Yayınları, 2005).

Pentzopoulos, Dimitri. The Balkan Exchange of Minorities and Its Impact upon Greece (Paris: Mouton \& Co / École pratique des hautes études, 1962).

Petropulos, John A. "The Compulsory Exchange of Populations: Greek-Turkish Peacemaking, 1922-1930” 2 (1976) Byzantine and Modern Greek Studies 135.

Petrov, Milen V. "Everyday Forms of Compliance: Subaltern Commentaries on Ottoman Reform, 1864-1868” 46 (2004) Comparative Studies in Society and History 730.

Phillimore, Robert. Commentaries upon International Law, Vol. I (Philadelphia: T. \& J. W. Johnson, 1854). 
Pictet, Jean, ed. La Convention de Genève relative à la protection des personnes civiles en temps de guerre (Genève: Comité international de la Croix-Rouge, 1956).

Pitts, Jennifer. "Boundaries of Victorian International Law" in Duncan Bell, ed., Victorian Visions of Global Order: Empire and International Relations in Nineteenth-Century Political Thought (Cambridge: Cambridge University Press, 2007) 67.

Politis, Nicolas. La guerre gréco-turque au point de vue du droit international: contribution à l'étude de la question d'Orient (Paris: A. Pedone, 1898).

---. "Le problème des limitations de la souveraineté et la théorie de l'abus des droits dans les rapports internationaux" 6 (1925-I) RCADI 1.

---. "Le transfert des populations" 54 (1940) L'esprit international 185.

---. La morale internationale (New York: Brentano’s, 1944).

Pomerance, Michla. Self-Determination in Law and Practice (The Hague: Nijhoff, 1982).

Pomeroy, John Norton. Lectures on International Law in Time of Peace, ed. Theodore Salisbury Woolsey (Boston: Houghton, Mifflin and Co., 1886).

Popplewell, Richard J. Intelligence and Imperial Defence: British Intelligence and the Defence of the Indian Empire 1904-1924 (London: Frank Cass, 1995).

Preece, Jennifer Jackson. National Minorities and the European Nation-States System (Oxford: Clarendon Press, 1998).

Psomiades, Harry J. The Eastern Question: The Last Phase - A Study in Greek-Turkish Diplomacy (Thessaloniki: Institute for Balkan Studies, 1968).

Quataert, Donald. "The Age of Reforms, 1812-1914" in Halil Inalc1k and Donald Quataert, eds., An Economic and Social History of the Ottoman Empire, Vol. II (Cambridge: Cambridge University Press, 1994) 759.

Rabinowicz, A. M. K. "Classical International Law and the Jewish Question" in H. Meijers and E. W. Vierdag, eds., Essays on International Law and Relations in Honour of A. J. P. Tammes (Leyden: Sijthoff, 1977) 205.

Raič, David. Statehood and the Law of Self-Determination (The Hague: Kluwer, 2002).

Rajagopal, Balakrishnan. International Law from Below: Development, Social Movements and Third World Resistance (Cambridge: Cambridge University Press, 2003).

Rajak, Svetozar. "The Cold War in the Balkans, 1945-1956" in Melvyn P. Leffler and Odd Arne Westad, eds., The Cambridge History of the Cold War, Vol. I (Cambridge: Cambridge University Press, 2010) 198. 
Rappard, William E. International Relations as Viewed from Geneva (New Haven: Yale University Press, 1925).

Reale, Egidio. "Le problème des passeports” 50 (1934-IV) RCADI 85.

Rechid, Ahmed. "La condition des étrangers dans la République de Turquie" 46 (1933-IV) RCADI 165.

Redslob, Robert. Le principe des nationalités: les origines, les fondements psychologiques, les forces adverses, les solutions possibles (Paris: Sirey, 1930).

Renan, Ernest. Qu'est-ce qu'une nation? Conférence faite en Sorbonne, le 11 mars 1882, 2 ${ }^{\text {nd }}$ Ed. (Paris: Ancienne maison Michel Lévy frères, 1882).

Rey, Francis "La question israélite en Roumanie” 10 (1903) RGDIP 460.

Ristelhuber, René. La double aventure de Fridjhof Nansen, explorateur et philanthrope (Montréal: Les éditions variétés, 1945).

Robinson, Jacob et al. Were the Minorities Treaties a Failure? (New York: Institute of Jewish Affairs, 1943).

Rodrigue, Aron. French Jews, Turkish Jews: The Alliance Israélite Universelle and the Politics of Jewish Schooling in Turkey, 1860-1925 (Bloomington: Indiana University Press, 1990).

Rolin-Jaequemyns, Gustave. "Le droit international et la phase actuelle de la question d'Orient" 8 (1876) RDILC 293.

---. "L’Arménie, les Arméniens et les traités" 21 (1889) RDILC 291.

Root, Elihu. "The Basis of Protection to Citizens Residing Abroad" in Elihu Root, Addresses on International Subjects, ed. Robert Bacon and James Brown Scott (Cambridge, MA: Harvard University Press, 1916) 43.

Ross, Frank A., C. Luther Fry, and Elbridge Sibley. The Near East and American Philanthropy: A Survey Conducted under the Guidance of the General Committee of the Near East Survey (New York: Columbia University Press, 1929).

Rosting, Helmer. "Protection of Minorities by the League of Nations" 17 (1923) AJIL 641.

Rougier, Antoine. "La théorie de l'intervention d'humanité” 12 (1910) RGDIP 468.

Rousseau, Jean-Jacques. The Social Contract and Other Late Political Writings, ed. Victor Gourevitch (Cambridge: Cambridge University Press, 1997).

Rudesco, Cornélius Alexandre. Étude sur la question des minorités de race, de langue et de religion (Lausanne: Librairie Payot \& Cie., 1928). 
Ruyssen, Théodore. Les minorités nationales d'Europe et la Guerre mondiale (Paris: Les presses universitaires de France, 1923).

Saraçoğlu, M. Safa. "Some Aspects of Ottoman Governmentality at the Local Level: The Judicio-Administrative Sphere of the Vidin County in the 1860s and 1870s" 9 (2008) Ab Imperio 223.

Sartiaux, Félix. "Le sac de Phocée et l'expulsion des Grecs ottomans d'Asie-Mineure en juin 1914” 24 (1914) Revue des deux mondes 654.

Sauser-Hall, Georges. "La réception des droits européens en Turquie" in Recueil de travaux publié à l'occasion de l'Assemblée de la Société suisse des juristes à Genève, du 4 au 6 septembre 1938 (Genève: Imprimerie Albert Kundig, 1938) 323.

Schechtmann, Joseph B. "The Option Clause in the Reich's Treaties on the Transfer of Populations" 38 (1944) AJIL 356.

--- [as Joseph B. Schechtman]. European Population Transfers 1939-1945 (New York: Oxford University Press, 1946).

Schenk, H. G. The Aftermath of the Napoleonic Wars: The Concert of Europe - An Experiment (New York: Howard Fertig, 1967).

Scheuermann, Martin. Minderheitenschutz contra Konfliktverbütung? Die Minderbeitenpolitik des Völkerbundes in den zwanziger Jahren (Marburg: Verlag Herder-Institut, 2000).

Schmitt, Carl. The Crisis of Parliamentary Democracy, tr. Ellen Kennedy (Cambridge, MA: The MIT Press, 1988 [1923]).

---. The Concept of the Political, tr. George Schwab (Chicago: University of Chicago Press, 1996 [1932]).

---. The Nomos of the Earth in the International Law of the Jus Publicum Europaeum, tr. G. L. Ulmen (New York: Telos, 2003 [1950]).

---. Theory of the Partisan: Intermediate Commentary on the Concept of the Political, tr. G. L. Ulmen (New York: Telos, 2007 [1975]).

---. Constitutional Theory, tr. and ed. Jeffrey Seitzer (Durham: Duke University Press, 2008 [1928]).

Schurer, Heinz. "Alexander Helphand-Parvus - Russian Revolutionary and German Patriot” 18 (1959) Russian Review 313.

Schwarzenberger, Georg. The League of Nations and World Order: A Treatise on the Principle of Universality in the Theory and Practice of the League of Nations (London: Constable \& Co., 1936).

---. "The Standard of Civilisation in International Law" 8 (1955) Current Legal Problems 212.

Schwelb, Egon. "Crimes against Humanity” 23 (1946) BYIL 178.

Selâhattin Bey, Ahmet. "Vekâlet ve Müzaheret", Tarik [1919], reproduced as "Mandat ve Yardım” in Lozan' in 50. Yul Armağan (İstanbul: Fakülteler Matbaası, 1978) 3. 
Sezer, Ayten. Atatürk Döneminde Yabancı Okullar (1923-1938) (Ankara: Türk Tarih Kurumu Basımevi, 1999).

Séfériadès, Stelio. “L'échange des populations” 24 (1928-IV) RCADI 307.

Sharma, Vishnu D. and Frank Wooldridge. "The Expulsion of the Ugandan Asians and Some Legal Questions Arising Therefrom” 7 (1974) Comparative and International Law Journal of Southern Africa 1.

Shaw, Stanford J. History of the Ottoman Empire and Modern Turkey, Vol. I (Cambridge: Cambridge University Press, 1976).

--- and Ezel Kural Shaw. History of the Ottoman Empire and Modern Turkey, Vol. II (Cambridge: Cambridge University Press, 1977).

---. "Ottoman Population Movements during the Last Years of the Empire, 1885-1914: Some Preliminary Remarks" 1 (1980) Osmanl Arastırmalar 191.

---. From Empire to Republic: The Turkish War of National Liberation 1918-1923: A Documentary Study, Vol. II (Ankara: Türk Tarih Kurumu Basımevi, 2000).

Shields, Sarah D. Fezzes in the River: Identity Politics and European Diplomacy in the Middle East on the Eve of World War II (Oxford: Oxford University Press, 2011).

Shmuelevitz, Aryeh. "Atatürk's Policy toward the Great Powers: Principles and Guidelines" in Uriel Dann, ed., The Great Powers in the Middle East 1919-1939 (New York: Holmes \& Meier, 1988) 311.

Shorter, Frederic C. “The Population of Turkey after the War of Independence” 17 (1985) International Journal of Middle East Studies 417.

Shupp, Paul F. The European Powers and the Near Eastern Question 1806-1807 (New York: Columbia University Press, 1931).

Simpson, A. W. Brian. Human Rights and the End of Empire: Britain and the Genesis of the European Convention (Oxford: Oxford University Press, 2004).

Simpson, Gerry. Great Powers and Outlaw States: Unequal Sovereigns in the International Legal Order (Cambridge: Cambridge University Press, 2004).

Skinner, Quentin. "States and the Freedom of Citizens" in Quentin Skinner and Bo Stråth, eds., States and Citizens: History, Theory, Prospects (Cambridge: Cambridge University Press, 2003) 11.

Skouteris, Thomas. The Notion of Progress in International Law Discourse (The Hague: T. M. C. Asser, 2010).

Skran, Claudena M. Refugees in Inter-war Europe: The Emergence of a Regime (Oxford: Clarendon Press, 1995). 
Smith, Leonard V. "Wilsonian Sovereignty in the Middle East: The King-Crane Commission Report of 1919" in Douglas Howland and Luise White, eds., The State of Sovereignty: Territories, Laws, Populations (Bloomington: Indiana University Press, 2009) 56.

Smith, Michael Llewellyn. Ionian Vision: Greece in Asia Minor 1919-1922, $2^{\text {nd }}$ Ed. (London: C. Hurst \& Co., 1998).

Smith, Neil. American Empire: Roosevelt's Geographer and the Prelude to Globalization (Berkeley: University of California Press, 2003).

Soguk, Nevzat. States and Strangers: Refugees and Displacements of Statecraft (Minneapolis: University of Minnesota Press, 1999).

Sohn, Louis B. "The Rights of Minorities" in Louis Henkin, ed., The International Bill of Rights: The Covenant on Civil and Political Rights (New York: Columbia University Press, 1981) 270.

Solonari, Vladimir. Purifying the Nation: Population Exchange and Ethnic Cleansing in Nari-Allied Romania (Washington and Baltimore: Woodrow Wilson Center Press / Johns Hopkins University Press, 2009).

Somel, Selçuk Akşin. The Modernization of Public Education in the Ottoman Empire, 1839-1908: Islamization, Autocracy and Discipline (Leiden: Brill, 2001).

Sousa, Nasim. The Capitulatory Régime of Turkey: Its History, Origin, and Nature (Baltimore: The Johns Hopkins Press, 1933).

Soutou, Georges-Henri. "Le Concert européen, de Vienne à Locarno" in Jean Bérenger and Georges-Henri Soutou, eds., L'ordre européen du XVIe an XXe siècle (Paris: Presses de l'Université de Paris-Sorbonne, 1998) 117.

Spiermann, Ole. International Legal Argument in the Permanent Court of International Justice: The Rise of the International Judiciary (Cambridge: Cambridge University Press, 2005).

Stevens, Marcia and Malcolm Stevens. Against the Devil's Current: The Life and Times of Cyrus Hamlin (Lanham, MD: University Press of America, 1988).

Stone, Julius. International Guarantees of Minority Rights: Procedure of the Council of the League of Nations in Theory and Practice (London: Oxford University Press, 1932).

---. Regional Guarantees of Minority Rights: A Study of Minorities Procedure in Upper Silesia (New York: Macmillan, 1933).

Stouraiti, Anastasia and Alexander Kazamias. "The Imaginary Topographies of the Megali Idea: National Territory as Utopia" in P. Nikiforos Diamandouros, Thalia Dragonas, and Çağlar Keyder, eds., Spatial Conceptions of the Nation: Modernizing Geographies in Greece and Turkey (London: Tauris, 2010) 11. 
Streit, Georgios S. Der Lausanner Vertrag und der griechisch-türkische Bevölkerungsaustausch (Berlin: Georg Stilke, 1929).

Stuart, John. "Beyond Sovereignty?: Protestant Missions, Empire and Transnationalism, 18901950" in Kevin Grant and Philippa Levine, eds., Beyond Sovereignty: Britain, Empire and Transnationalism, c. 1880-1950 (Houndsmills: Palgrave Macmillan, 2007) 103.

Suny, Ronald Grigor, Fatma Müge Göçek, and Norman M. Naimark, eds. A Question of Genocide: Armenians and Turks at the End of the Ottoman Empire (Oxford: Oxford University Press, 2011).

Sylvest, Casper. "International Law in Nineteenth-Century Britain” 75 (2004) BYIL 9.

Symonds, Arthur G. "The Balkan Committee 1905-1913” in Memories of John Westlake (London: Smith, Elder \& Co., 1914) 107.

Szporluk, Roman. Communism and Nationalism: Karl Marx versus Friedrich List (Oxford: Oxford University Press, 1988).

Şeker, Nesim. "Demographic Engineering in the Late Ottoman Empire and the Armenians" 43 (2007) Middle Eastern Studies 461.

Şimşir, Bilâl N., ed. Dış Basında Atatürk ve Türk Devrimi, Vol. I (Ankara: Türk Tarih Kurumu Basimevi, 1981).

--- ed. Ege Sorunu: Belgeler, Vol II. (Ankara: Türk Tarih Kurumu Basımevi, 1982).

--- ed. Lozan Telgraflar: Türk Diplomatik Belgelerinde Lozan Barsş Konferansı, Vol. I (Ankara: Türk Tarih Kurumu Basimevi, 1990).

---. Bizim Diplomatlar (Ankara: Bilgi Yayınevi, 1996).

Tachi, Sakutaro. "La souveraineté et le droit territorial de l'État” 38 (1931) RGDIP 406.

Tait, D. Christie. "International Aspects of Migration" 6 (1927) Journal of the Royal Institute for International Affairs 25.

Tanör, Bülent. Osmanl-Türk Anayasal Gelismeleri (1789-1980) (İstanbul: Yap1 Kredi Yayınlar1, 1998).

Taylor, A. J. P. The Struggle for Mastery in Europe 1848-1918 (Oxford: Clarendon Press, 1954).

Tejirian, Eleanor and Reeva Simon, eds. Altruism and Imperialism: Western Cultural and Religious Missions in the Middle East (New York: Middle East Institute, Columbia University, 2002).

Temperley, Harold William Vazeille, ed. A History of the Peace Conference of Paris, Vol. V (London: Oxford University Press, 1921).

--- [as Harold Temperley]. "The Treaty of Paris of 1856 and Its Execution" 4 (1932) Journal of Modern History 523. 
Teyssaire, Jean. "Les concessions et le traité de Lausanne” 35 (1928) RGDIP 447.

Ténékidès, C. G. "Le statut des minorités et l'échange obligatoire des populations grécoturques" 31 (1924) RGDIP 72.

---. "Le droit international public envisagé comme source du droit interne hellénique" 9 (1928) RDILC 338.

Thompson, Joseph P. American Comments on European Questions, International and Religious (Boston: Houghton, Mifflin \& Co., 1884).

Thornberry, Patrick. International Law and the Rights of Minorities (Oxford: Clarendon Press, 1991).

Thorne, Susan. "The Conversion of Englishmen and the Conversion of the World Inseparable': Missionary Imperialism and the Language of Class in Early Industrial Britain" in Frederick Cooper and Ann Laura Stoler, eds., Tensions of Empire: Colonial Cultures in a Bourgeois World (Berkeley: University of California Press, 1997) 238.

Thornton, A. P. Doctrines of Imperialism (New York: John Wiley \& Sons, 1965).

Thornton, Thomas. The Present State of Turkey; or A Description of the Political, Civil, and Religious, Constitution, Government, and Laws of the Ottoman Empire ..., $2^{\text {nd }}$ Ed. (London: Joseph Mawman, 1809).

Toprak, Zafer. Türkiye'de “Milli İktisat” (1908-1918) (İstanbul: Yurt Yayınlar1, 1982).

Torpey, John. The Invention of the Passport: Surveillance, Citizenship and the State (Cambridge: Cambridge University Press, 2000).

---. "The Great War and the Birth of the Modern Passport System" in Jane Caplan and John Torpey, eds., Documenting Individual Identity: The Development of State Practices in the Modern World (Princeton: Princeton University Press, 2001) 256.

Toumarkine, Alexandre. Les migrations des populations musulmanes balkaniques en Anatolie (18761913) (İstanbul: Les éditions Isis, 1995).

Toynbee, Arnold J. The Western Question in Greece and Turkey: A Study in the Contact of Civilisations, 2nd Ed. (London: Constable and Co. Ltd., 1923).

---. "The East after Lausanne" 2 (1923-4) Foreign Affairs 84.

Triadafilopoulos, Triadafilos. "The Political Consequences of Forced Population Transfers: Refugee Incorporation in Greece and West Germany" in Rainer Ohliger, Karen Schönwälder, and Triadafilos Triadafilopoulos, eds., European Encounters: Migrants, Migration, and European Societies since 1945 (Aldershot: Ashgate, 2003) 99.

Trubek, David M., Yves Dezalay, Ruth Buchanan, and John R. Davis. "Global Restructuring and the Law: Studies of the Internationalization of Legal Fields and the Creation of Transnational Arenas” 44 (1994) Case Western Reserve Law Review 407. 
Tunaya, Tarık Zafer. Türkiye'de Siyasal Partiler, Vols. II and III, $2^{\text {nd }}$ Ed. (İstanbul: Hürriyet Vakfi Yayinlar1, 1986 and 1989).

Turlington, Edgar. "The Settlement of Lausanne” 18 (1924) AJIL 696.

Ursinus, M. O. H. "Millet", in C. E. Bosworth et al., eds., The Encyclopaedia of Islam: New Edition, Vol. VII (Leiden: Brill, 1990) 61.

Ülker, Erol. “Contextualising 'Turkification': Nation-Building in the Late Ottoman Empire, 1908-18" 11 (2005) Nations and Nationalism 613.

---. "Assimilation, Security and Geographical Nationalization in Interwar Turkey: The Settlement Law of 1934" 7 (2008) European Journal of Turkish Studies, available online at: http://w ww.ejts.org/do cument2123.html (last accessed 6 April 2011).

Vagts, Detlev F. “International Law in the Third Reich” 84 (1990) AJIL 661.

van Asbeck, F. M. "The Relationship between International and Colonial Law” [1931] in F. M. van Asbeck, International Society in Search of a Transnational Legal Order: Selected Writings and Bibliography, eds. H. F. van Panhuys and M. van Leeuwen Boomkamp (Leyden: Sijthoff, 1976) 48.

van Bruinessen, Martin. Agha, Shaikh and State: The Social and Political Structures of Kurdistan (London: Zed Books, 1992).

van den Boogert, Maurits H. The Capitulations and the Ottoman Legal System: Qadis, Consuls, and Beratlis in the $18^{\text {th }}$ Century (Leiden: Brill, 2005).

Vec, Miloš. 'De-Legitimizing 'Balance of Power': Principles in International Legal Doctrine", paper presented at the $4^{\text {th }}$ Research Forum of the European Society of International Law at the University of Tartu (26 May 2011).

Venizelos, Eleutherios. Greece in Her True Light: Her Position in the World-Wide War as Expounded by El. K. Venizelos (New York: n.p., 1916).

Verzijl, J. H. W. The Jurisprudence of the World Court: A Case by Case Commentary, Vol. I (Leyden: Sijthoff, 1965).

---. International Law in Historical Perspective, Vols. I and V (Leiden: Sijthoff, 1972).

Vlami, Despina. "Entrepreneurship and Relational Capital in a Levantine Context: Bartholomew Edward Abbott, the 'Father of the Levant Company' in Thessaloniki (Eighteenth-Nineteenth Centuries)" 6 (2009) Historical Review 129.

von Elbe, Joachim. "Peacemaking in 1815” 36 (1942) AJIL 470.

von Jhering, Rudolf. Law as a Means to an End, tr. Isaac Husik (Boston: Boston Book Company, 1913 [1877]). 
von Treitschke, Heinrich. Politics, tr. Blanche Dugdale and Torben de Bille (London: Constable and Co., 1916 [1897-8]).

Voorhees, Dayton. "The League of Nations: A Corporation, not a Superstate" 20 (1926) American Political Science Review 847.

Vucinich, Wayne S. “The Nature of Balkan Society under Ottoman Rule” 21 (1962) Slavic Review 597.

Wallerstein, Immanuel. The Modern World-System: Capitalist Agriculture and the Origins of the European World-Economy in the Sixteenth Century (New York: Academic Press, 1974).

---. The Modern World-System II: Mercantilism and the Consolidation of the European World-Economy, 1600-1750 (New York: Academic Press, 1980).

--- Hale Decdeli, and Reşat Kasaba. "The Incorporation of the Ottoman Empire into the World-Economy" in Huri İslamoğlu-İnan, ed., The Ottoman Empire and the World-Economy (Cambridge: Cambridge University Press, 1987) 88.

---. The Modern World-System III: The Second Era of Great Expansion of the Capitalist World-Economy, 1730s-1840s (San Diego: Academic Press, 1989).

---. The Modern World-System IV: Centrist Liberalism Triumphant, 1789-1914 (Berkeley: University of California Press, 2011).

Wambaugh, Sarah. Plebiscites since the World War, with a Collection of Official Documents, Vol. I (Washington: Carnegie Endowment for International Peace, 1933).

Ward, Robert. An Enquiry into the Foundation and History of the Law of Nations in Europe, from the Time of the Greeks and Romans, to the Age of Grotius, Vol. II (London: A. Strahan and W. Woodfall, 1795).

Watenpaugh, Keith David. “The League of Nations' Rescue of Armenian Genocide Survivors and the Making of Modern Humanitarianism, 1920-1927” 115 (2010) American Historical Review 1315.

Webster, Donald E. "State Control of Social Change in Republican Turkey" 4 (1939) American Sociological Review 247.

Weitz, Eric D. "From the Vienna to the Paris System: International Politics and the Entangled Histories of Human Rights, Forced Deportations, and Civilizing Missions" 113 (2008) American Historical Review 1313.

Westlake, John. Chapters on the Principles of International Law (Cambridge: Cambridge University Press, 1894).

---. "The Balkan Question and International Law" 60 (1906) The Nineteenth Century and After 889.

---. "Territorial Sovereignty, Especially with Relation to Uncivilised Regions" in The Collected Papers of John Westlake on Public International Law, ed. Lassa Oppenheim (Cambridge: Cambridge University Press, 1914) 131. 
Wheaton, Henry. Elements of International Law, With a Sketch of the History of the Science, Vol. I (London: B. Fellowes, 1836).

Wheeler-Bennett, J. W. Information on the World Court, 1918-1928 (London: George Allen \& Unwin Ltd., 1929).

White, Wilbur Wallace. The Status in International Law of the Fragments of the Ottoman Empire (Chicago: University of Chicago Press, 1938).

Williams, Brian Glyn. "Hijra and Forced Migration from Nineteenth-Century Russia to the Ottoman Empire: A Critical Analysis of the Great Crimean Tatar Emigration of 1860-1861" 41 (2000) Cabiers du monde russe 79.

Wilson, Robert R. "Interpretation of Treaties: Contributions of the Permanent Court of International Justice to the Development of International Law" 24 (1930) ASIL Pd. 39.

---. "Some Aspects of Treaty Interpretation" 33 (1939) AJIL 541.

Winfield, P. H. “The Grounds of Intervention in International Law” 5 (1924) BYIL 149.

Wolf, Lucien. Notes on the Diplomatic History of the Jewish Question (London: Spottiswoode, Ballantyne \& Co. Ltd., 1919).

Wood, Alfred C. A History of the Levant Company (London: Oxford University Press, 1935).

Wood, Hugh McKinnon. "The Treaty of Paris and Turkey's Status in International Law” 37 (1943) AJIL 262.

Woolsey, L. H. “The Unilateral Termination of Treaties” 20 (1926) AJIL 346.

Worringer, Renée. “'Sick Man of Europe' or 'Japan of the Near East'?: Constructing Ottoman Modernity in the Hamidian and Young Turk Eras" 36 (2004) International Journal of Middle East Studies 207.

Wright, Quincy. “The Mosul Dispute” 20 (1926) AJIL 453.

Wurfbain, André. L'échange gréco-bulgare des minorités ethniques (Lausanne: Librairie Payot \& Cie, 1930).

Yerasimos, Stefanos. Türk-Sovyet Illişkileri: Ekim Devriminden "Milli Mücadele”ye (İstanbul: Gözlem, 1979).

Yildirım, Onur. "The 1923 Population Exchange, Refugees and National Historiographies in Greece and Turkey" 40 (2006) East European Quarterly 45.

---. Diplomacy and Displacement: Reconsidering the Turco-Greek Exchange of Populations, 1922-1934 (New York: Routledge, 2006). 
Yurdusev, A. Nuri. "The Ottoman Attitude toward Diplomacy" in A. Nuri Yurdusev, ed., Ottoman Diplomacy: Conventional or Unconventional? (Houndmills: Palgrave Macmillan, 2004) 5.

Zeman, Z. A. B. and W. B. Scharlau. The Merchant of Revolution: The Life of Alexander Israel Helphand (Parvus) 1867-1918 (London: Oxford University Press, 1965).

Zimmern, Alfred. The League of Nations and the Rule of Law, 1918-1935 (London: Macmillan / St. Martin's, 1936).

Zürcher, Erik Jan. The Unionist Factor: The Rôle of the Committee of Union and Progress in the Turkish National Movement, 1905-1926 (Leiden: Brill, 1984).

---. "The Ottoman Legacy of the Turkish Republic: An Attempt at a New Periodization" 32 (1992) Die Welt des Islams 237.

--- [as Erik-Jan Zürcher]. "The Young Turks: Children of the Borderlands?” 9 (2003) International Journal of Turkish Studies 275.

---. "How Europeans Adopted Anatolia and Created Turkey" 13 (2005) European Review 379. 